\title{
SUbSídios PARA A QUARENTENA VEGETAL. I. AVALIAÇÃo DA IMPORTÂNCIA QUARENTENÁRIA DE ÁCAROS ASSOCIADOS A CULTURAS FRUTÍFERAS PARA O BRASIL. H. DISSEMINAÇÃO DE ÁCAROS FITÓfagos ATRAVÉS de MATERIAL PARA PROPAGAÇÃo VEGETATIVA DE Arachis pintoi (Krap. \& Greg.) (FABACEAE).
}

\author{
Denise Návia Magalhães Ferreira \\ Bióloga
}

\begin{abstract}
Orientador: Pro $\equiv$. CARLOS HOLGER WENZEL FLECHTMANN
Dissertação apresentada à Escola Superior de Agricultura "Luiz de Queiroz", Universidade de São Paulo para obtenção do título de Mestre em Ciências, Área de Concentração: Entomologia
\end{abstract}

PIRACICABA

Estado de São Paulo - Brasil

Agosto - 1997 


\section{Dados Internacionais de Catalogação na Publicação (CIP) DIVISĀO DE BIBLIOTECA E DOCUMENTAÇĀO - Campus "Luiz de Queiroz"/USP}

Ferreira, Denise Návia Magalhāes

Subsidios para a quarentena vegetal. l. avaliaçāo da importância quarentenária de ácaros associados a culturas frutíferas para o Brasil. Il. disseminaçāo de ácaros fitófagos através de material para propagaçāo vegetativa de Arachis pintoi (Krap. \& Greg.) (Fabaceae) / Denise Návia Magalhāes Ferreira. - - Piracicaba, 1997.

300 p. : il.

Dissertaçāo (mestrado) - . Escola Superior de Agricultura Luiz de Queiroz, 1997. Bibliografia.

1. Ácaro fitófago (disseminaçāo) 2. Controle fitossanitário 3. Fruticultura 4. Leguminosa (propagaçāo) 5. Praga agricola 6. Quarentena (vegetal) I. Título 
SUBSídios PARA A QUARENTENA VEGETAL. I. AVALIAÇ̃̃o DA IMPORTÂNCIA QUARENTENÁRIA DE ÁCAROS ASSOCIADOS A CULTURAS FRUTÍFERAS PARA O BRASIL. II. DISSEMINAÇÃO DE ÁCAROS FITÓfagos ATraVÉS de MATERIAL PARA PROPAGAÇÃo VEGETATIVA DE Arachis pintoi (Krap. \& Greg.) (FABACEAE).

Denise Návia Magalhães Ferreira

Aprovada em 26.09.1997

Comissão julgadora:

Dr. Carlos Holger Wenzel Flechtmann

ESALQ/USP

Prof. Dr. Gilberto José de Moraes

ESALQ/USP

Dr. Olivier Bonato

ORSTOM/CNPMA-EMBRAPA

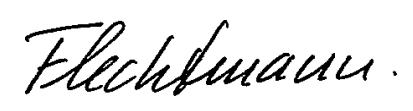

Dr. Carlos Holger W. Flechtmann Orientador 
Aos meus pais Harold e Maria de Lourdes, e irmãos Alexis e Elyn,

pelo incentivo, apoio e compreensão

\section{DEDICO}

À Deus, energia criadora

AGRADEÇO 
Aos Professores Carlos Holger W. Flechtmann

e Gilberto José de Moraes,

pela orientação, apoio e exemplo de dedicação

Agradeço especialmente 


\section{AGRADECIMENTOS}

Ao Centro Nacional de Pesquisa em Recursos Genéticos e Biotecnologia, EMBRAPA, pela oportunidade de realização do curso.

À Coordenadoria de Aperfeiçoamento de Pessoal de Nível Superior - CAPES, pela bolsa de estudos concedida.

À Maria Regina Vilarinho de Oliveira, pesquisadora CENARGEN, EMBRAPA, pela bibliografia concedida, apoio, incentivo e amizade.

Aos senhores Fernando Bueno de Avellar Pires, SFFV, DFA, São Paulo e Adauto Lima Rodrigues, SDV, Brasilia, pelo fornecimento dos dados sobre importações brasileiras de produtos vegetais do SIMEX.

À Marilene Fancelli, Pesquisadora CNPMF, EMBRAPA, pela bibliografia sobre comercialização de frutas brasileiras.

À Raimunda M. B. Almeida, Instituto Nacional de Meteorologia, pela bibliografia concedida.

Aos Professores do Departamento de Entomologia ESALQ, USP, pelos ensinamentos transmitidos.

Aos senhores Alan Kardec Braga Ramos e Esteban Alberto Pizarro, Centro Nacional de Pesquisa Agropecuária do Cerrado, EMBRAPA, por autorizar e assistir à coleta de material vegetal para as pesquisas. 
Às bibliotecárias Eliana Maria Garcia Sabino e Kátia Maria de Andrade Ferraz, pelo auxílio na organização das referência bibliográficas e aos demais funcionários da Biblioteca Central, pela colaboração durante todo o curso.

Ao colega, amigo e namorado Elton Lucio de Araújo, pelo apoio, incentivo, compreensão e companheirismo durante o curso.

À Maria Aparecida Leão Bittencourt, doutoranda ESALQ, USP, pelo companheirismo e incentivo.

A todos os colegas e amigos dos Departamentos de Entomologia e Zoologia, ESALQ, USP, pela amizade e carinho.

Aos funcionários dos Departamentos de Entomologia e Zoologia, ESALQ, USP, que direta ou indiretamente muito colaboraram para a execução do trabalho. 


\section{SUMÁRIO}

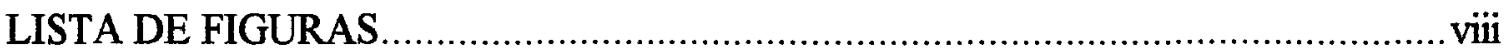

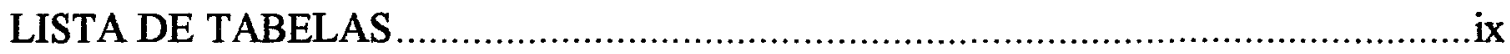

RESUMO

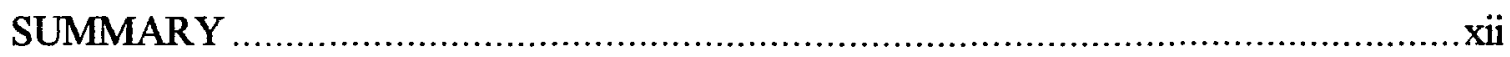

1 INTRODUÇÃO

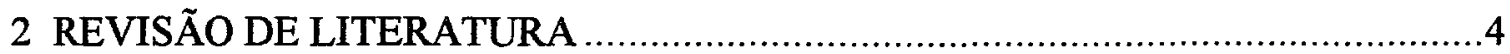

2.1 Introdução de organismos nocivos através da atividade humana .............................4

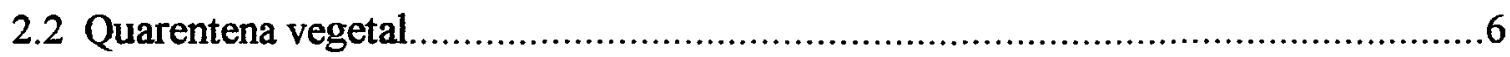

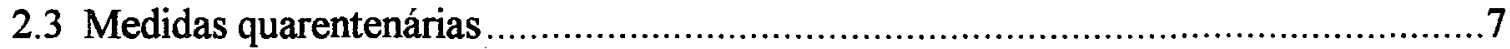

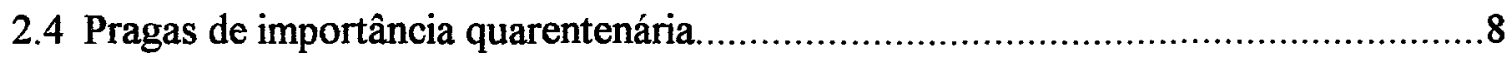

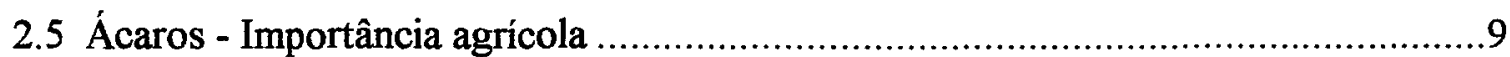

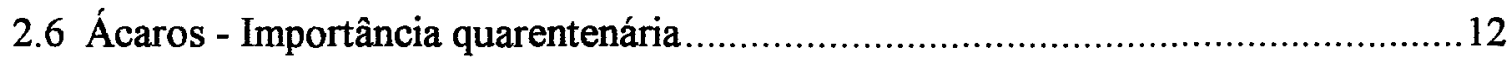

2.7 Problemas ocasionados pela introdução de novas espécies de ácaros .....................13

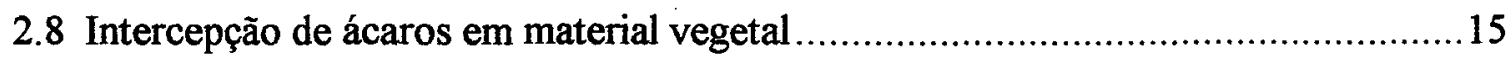

3 AVALIAÇÃO DA IMPORTÂNCIA QUARENTENÁRIA DE ÁCAROS ASSOCIADOS A CULTURAS FRUTÍFERAS PARA O BRASIL ..........18

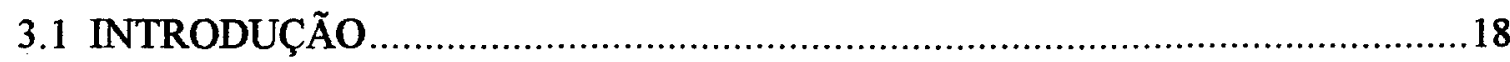

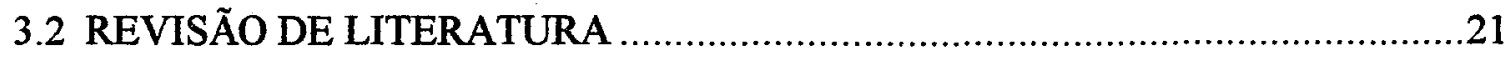

3.2.1 Produção e comercialização de frutos no Brasil .................................................21

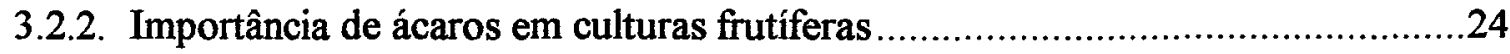

3.2.3 Possibilidade de introdução de ácaros através da importação de frutas ou

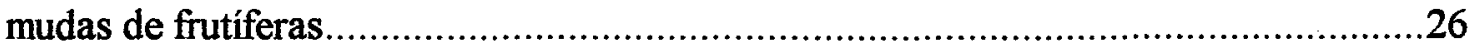


3.2.4 Problemas causados pela introdução de ácaros-praga associados a

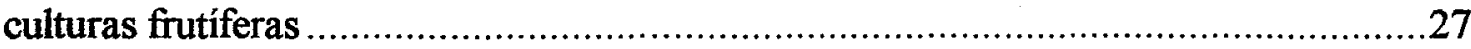

3.2.5 Ácaros de importância quarentenária associados a culturas frutíferas .................29

3.2.6 Determinação de pragas de importância quarentenária - Análise de Risco

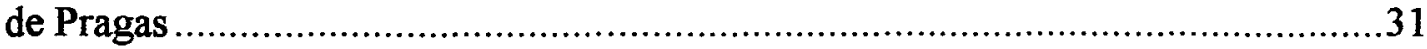

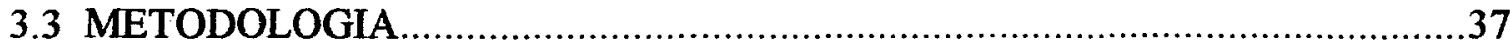

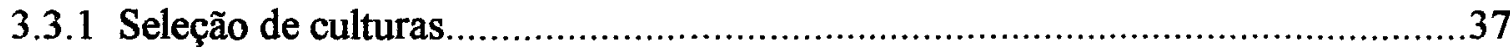

3.3.2 Seleção de espécies de ácaros cuja importância quarentenária foi avaliada ..........37

3.2.3 Avaliação da importância quarentenária das espécies alistadas ............................38

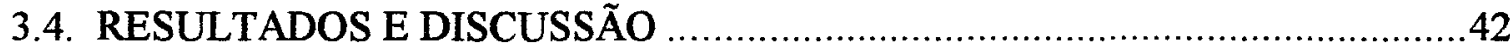

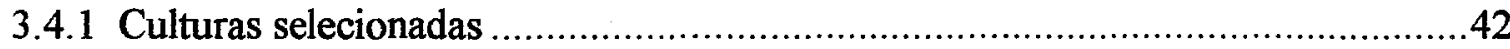

3.4.2 Espécies cuja importância quarentenária foi avaliada .......................................43

3.4.3 Avaliação da importância quarentenária de ácaros associados à maçã e/ou

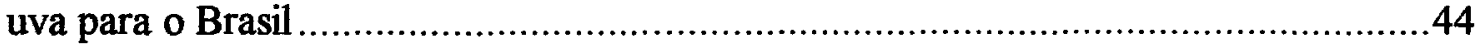

3.4.3.1 Aculus schlechtendali (Nalepa, 1890) (Eriophyidae)......................................44

3.4.3.2 Amphitetranychus viennensis (Zacher, 1920) (Tetranychidae) ........................56

3.4.3.3 Brevipalpus chilensis Baker, 1949 (Tenuipalpidae) ....................................65

3.4.3.4 Brevipalpus lewisi McGregor, 1949 (Tenuipalpidae) ..................................72

3.4.3.5 Bryobia rubrioculus (Scheuten, 1857) (Tetranychidae) ................................. 81

3.4.3.6 Cenopalpus pulcher (Canestrini \& Fanzago, 1876) (Tenuipalpidae).................92

3.4.3.7 Eotetranychus carpini (Oudemans, 1905) (Tetranychidae) ...........................100

3.4.3.8 Eotetranychus willamettei (McGregor, 1917) (Tetranychidae)......................108

3.4.3.9 Oligonychus vitis Zaher \& Shehata, 1965 (Tetranychidae)............................116

3.4.3.10 Panonychus ulmi (Koch, 1836) (Tetranychidae) .......................................117

3.4.3.11 Tetranychus canadensis (McGregor, 1950) (Tetranychidae)......................131

3.4.3.12 Tetranychus mcdanieli McGregor, 1931 (Tetranychidae) ...........................133

3.4.3.13 Tetranychus pacificus McGregor, 1919 (Tetranychidae) ..........................142

3.4.3.14 Tetranychus schoenei McGregor, 1941 (Tetranychidae) ...........................152

3.4.3.15 Tetranychus turkestani (Ugarov \& Nikolskii, 1937) (Tetranychidae) ............154

3.4.3.16 Tetranychus urticae Koch, 1836 (Tetranychidae) .....................................165 


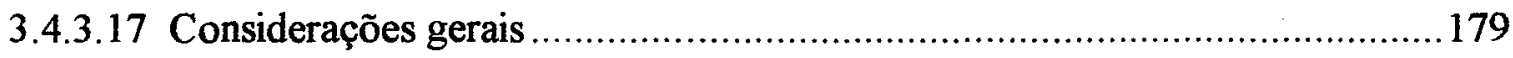

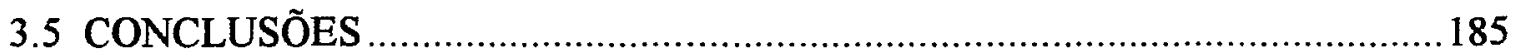

4 DISSEMINAÇÃO DE ÁCAROS FITÓFAGOS ATRAVÉS DE

MATERIAL PARA PROPAGAÇÃO VEGETATIVA DE Arachis pintoi

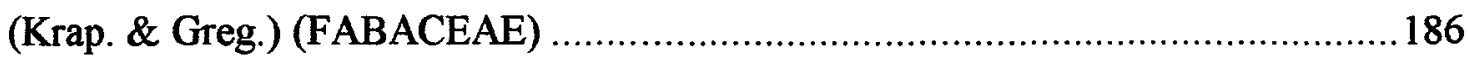

4.1 INTRODUÇÃO

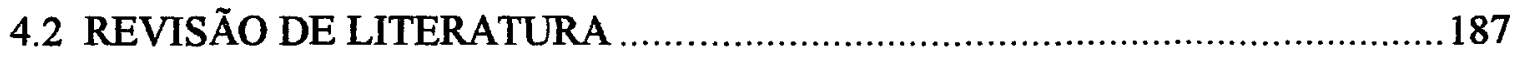

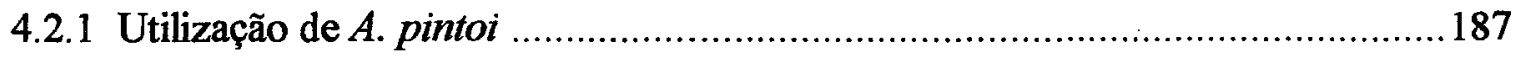

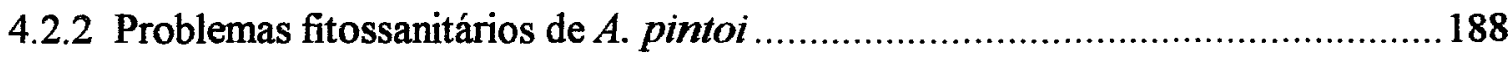

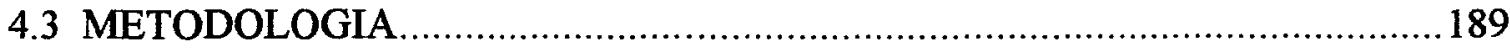

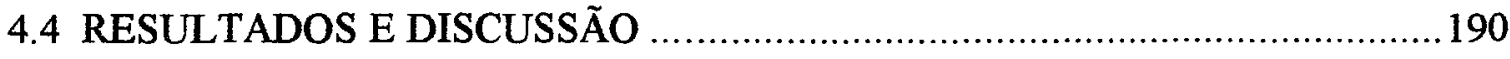

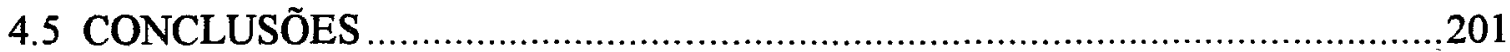

ANEXO A - ÁCAROS INTERCEPTADOS EM MATERIAL VEGETAL

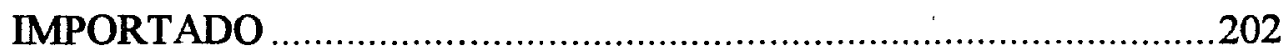

ANEXO B - IMPORTAÇÕES BRASILEIRAS DE PRODUTOS VEGETAIS..........210

ANEXO C - FREQUÊNCIA E VOLUME DAS IMPORTAÇÕES

BRASILEIRAS DE PRODUTOS VEGETAIS AO LONGO DO ANO .218

ANEXO D - DESTINO DAS IMPORTAÇÕES BRASILEIRAS

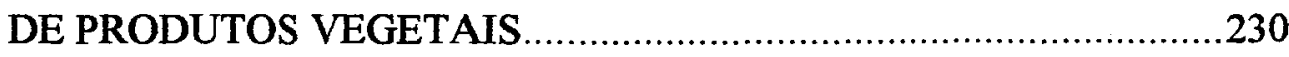

ANEXO E - CONDIÇÕES RECOMENDADAS PARA O TRANSPORTE

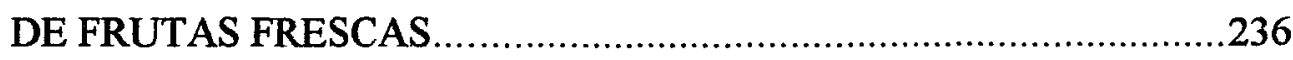

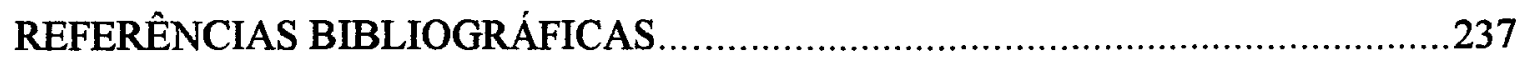


4.1 - 8 Tetranychus ogmophallos Ferreira \& Flechtmann, 1997, fềmea.

4.15 - 20 Aceria pintoi Ferreira \& Flechtmann, 1997, fềmea 200

4. 21 - 22 Aceria pintoi Ferreira \& Flechtmann, 1997, macho 200 


\section{LISTA DE TABELAS}

Tabela

Título

Página

1 Produção de culturas frutíferas no Brasil

2 Destino das exportações brasileiras de frutas frescas

por grandes blocos em 1992

3 Importação de frutas frescas de janeiro de 1992 a agosto de 1996 pelo Brasil

4 Número de espécies de ácaros-praga associados à culturas agrícolas, por gêneros. 24

5 Ácaros de importância quarentenária para os países do Cone Sul. .29

6 Ácaros de importância quarentenária associados a frutíferas 30

7 Ácaros de importância quarentenária para diversos países e RPPO's associados a frutíferas

8 Ácaros-praga associados às culturas de maçã/uva cuja importância quarentenária foi avaliada

9 Ocorrência de populações de T. urticae resistentes a pesticidas, por país

10 Avaliação do potencial de importância econômica, introdução e estabelecimento no Brasil de espécies de ácaros associados às culturas da uva e maçã

11 Vias de ingresso, culturas ameaçadas e destino dos produtos importados potencialmente infestados pelas espécies de importância quarentenária associadas à uva e maçã 


\section{SUbSídios PARA A QUARENTENA VEGETAL. I. AVALIAÇÃo DA IMPORTÂNCIA QUARENTENÁRIA dE ÁCAROS ASSOCIAdOS A CULTURAS FRUTífERAS PARA O BRASIL. II. DISSEMINAÇÃo dE ÁCAROS FITÓFAGOS ATRAVÉS DE MATERIAL PARA PROPAGAÇÃo VEGETATIVA DE Arachis pintoi (Krap. \& Greg.) (FABACEAE).}

Autora: DENISE NÁVIA MAGALHÃES FERREIRA Orientador: Prof. CARLOS HOLGER WENZEL FLECHTMANN

\section{RESUMO}

O trabalho consta de duas partes distintas. Em uma delas avaliou-se a importância quarentenária de ácaros fitófagos associados a culturas frutiferas para o Brasil. Foram escolhidas duas culturas - uva e maçã - devido à sua importância econômica e devido à importação de frutos ou mudas representar risco de introdução de espécies ou biótipos nocivos de ácaros não assinalados no país. A avaliação foi realizada através da Análise de Risco de Pragas (ARP), seguindo os critérios adotados pela FAO. Foram consideradas as características bioecológicas, hospedeiros, distribuição geográfica, danos e perdas causadas e métodos de controle utilizados para cada espécie, além de informações sobre as importações brasileiras de produtos vegetais (volume, freqüência, origem, destino). Seis espécies de ácaros - Aculus schlechtendali (Nalepa), Brevipalpus chilensis Baker, Eotetranychus carpini (Oudemans), Tetranychus mcdanieli McGregor, Tetranychus pacificus McGregor e Tetranychus turkestani (Ugarov \& Nikolskii) - apresentaram alto potencial de importância econômica, introdução e estabelecimento no país. Duas 
outras espécies - Panonychus ulmi (Koch) e Tetranychus urticae Koch - que apresentam biótipos resistentes a pesticidas ou que infestam hospedeiros distintos em outros países, também apresentaram alto potencial de importância econômica e introdução. Além de danos à videiras e macieiras, algumas destas espécies podem vir a causar sérios problemas a outras culturas frutíferas e mesmo a culturas extensivas de grande importância no país. Portanto, observa-se a necessidade da adoção de medidas quarentenárias para minimizar o risco de introdução destas pragas no país. Também é necessário revisar a lista vigente de pragas de importância quarentenária para o Brasil, no que se refere a ácaros. Somente T. pacificus, dentre as espécies para que se dispõe de dados suficientes para que sejam consideradas de importância quarentenária para o país, está presente na atual lista. $\mathrm{Na}$ outra parte do trabalho, avaliaram-se os ácaros fitófagos associados à Arachis pintoi (Krap. \& Greg.) (Fabaceae) para verificar a possibilidade de disseminação destes organismos juntamente com material para propagação. Esta leguminosa é originária do Brasil e vêm sendo amplamente distribuida no pais e exportada para ser utilizada principalmente como fixadora de nitrogênio atmosférico em pastagens. Para a propagação desta planta comumente utilizam-se estolhos, o que possibilita a veiculação de pragas. Foram detectadas duas espécies novas de ácaros fitófagos, as quais foram descritas. Aceria pintoi Ferreira \& Flechtmann (Eriophyidae) foi encontrada nas gemas, causando leve bronzeamento, e Tetranychus ogmophallos Ferreira \& Flechtmann (Tetranychidae) foi encontrado formando colônias por toda a planta, causando clorose nas folhas. Em laboratório, colônias de T. ogmophallos foram tranferidas para plantas de Arachis prostrata Benth., utilizado em associação com gramíneas em jardins; e amendoim, Arachis hypogea L. As colônias desenvolveram-se bem em ambas espécies, causando danos severos e morte das plantas. Portanto, evidenciou-se a possibilidade de disseminação de ácaros fitófagos através de material para propagação vegetativa de $A$. pintoi, os quais podem ser nocivos à cultura desta leguminosa, bem como a pelo menos uma outra cultura de importância econômica, $o$ amendoim. 


\section{SUBSIDIES TO PLANT QUARANTINE. I. ASSESSMENT OF QUARANTINE IMPORTANCE TO BRAZIL OF MITES ASSOCIATED WITH FRUIT CROPS. I. DISSEMINATION OF PHYTOPHAGOUS MITES ON Arachis pintoi (Krap. \& Greg.) (Fabaceae) PROPAGATION PARTS.}

Author: DENISE NÁVIA MAGALHÃÉS FERREIRA Adviser: Prof. CARLOS HOLGER WENZEL FLECHTMANN

\section{SUMMARY}

This research work consisted of two parts. In one part, the quarantine importance to Brazil of phytophagous mites associated with fruit crops was evaluated. Two crops, grape and apple, were selected for study because of their economic importance and because the importation of their fruits or cuttings constitute risk of introduction of harmful mite species or biotypes not present in the country. The assessment was conducted according to a protocol of Pest Risk Assessment (PRA) established by FAO. Characteristics of bioecology, hosts, geographic distribution, damages, losses, available control methods to the species as well as volume, frequency and source of importation of agricultural products were considered. Six mite species - Aculus schlechtendali (Nalepa), Brevipalpus chilensis Baker, Eotetranychus carpini (Oudemans), Tetranychus mcdanieli McGregor, Tetranychus pacificus McGregor and Tetranychus turkestani (Ugarov \& Nikolskii) - showed high potential for economic importance, introduction and establishment in Brazil. Two other species - Panonychus ulmi (Koch) and Tetranychus urticae Koch - that have biotypes resistant to different pesticides or that infest different 
hosts have high potential for economic importance and for introduction. In addition to grape and apple, those mites can cause severe damage to other fruit crops and to some economic field crops in the country. Thus, quarantine measures are necessary to minimize risks of introduction of these mite pests. The list of quarantine pests to Brazil needs revision, in relation to mites. Of the species pointed in this research, only $T$. pacificus is placed on the current list of quarantine pests. In the other part of the work, phytophagous mites associated with Arachis pintoi (Krap. \& Greg.) (Fabaceae) were assessed to determine the possibility of dissemination of these organisms on propagation parts. This leguminous plant native to Brazil has been widely distributed in the country as well as exported to be utilized in atmosphere nitrogen fixation in pastures. The propagation of this plant is commonly done with stolons, that could carry pest species. Two new mite species were detected and described. Aceria pintoi Ferreira \& Flechtmann (Eriophyidae) was found in the buds, causing light rustening, and Tetranychus ogmophallos Ferreira \& Flechtmann were observed in colonies all over the plant, causing leaf discoloration. In the laboratory, colonies of T. ogmophallos were transferred to plants of Arachis prostrata Benth., used in association with grasses in gardens, and of peanuts, Arachis hypogeae L. . The colonies thrived on both plants, causing severe damage and death. This indicated the possibility of dissemination of phytophagous mites through propagation parts of A. pintoi. The mites can be damaging to $A$. pintoi crops as well as to at least one crop of economic importante, peanut. 


\section{INTRODUÇÃO}

O desenvolvimento do transporte, comércio e intercâmbio de materiais vegetais entre países tem levado à rápida disseminação de pragas originalmente restritas às suas respectivas áreas de origem (Peña, 1997).

A introdução de pragas exóticas em áreas de produção pode causar diversos problemas, como redução na produtividade agrícola ou aumento nos custos de produção (Kogan, 1997; Peña, 1997). O impacto negativo da introdução de pragas em áreas isentas deve ser considerado não somente sob o ponto de vista econômico, mas também ambiente, devido ao efeito de medidas de controle adotadas contra a nova praga sobre organismos não-alvo e competição com as espécies nativas (Kogan, 1997).

Para diminuir os riscos de introdução de espécies nocivas, adotam-se medidas quarentenárias, que podem ser de natureza diversa. As medidas quarentenárias têm como referência principal a lista de pragas de importância quarentenária para o país. Por isto, esta deve ser cuidadosamente elaborada, seguindo critérios definidos, através de um processo denominado Análise de Risco de Pragas (ARP) (Brasil, 1995).

No presente momento, a revisão da legislação fitossanitária e o fortalecimento do serviço de quarentena vegetal é de fundamental importância para a proteção do setor agrícola e para o desenvolvimento econômico do país, devido a acordos internacionais sobre comércio entre países e entre blocos econômicos.

No âmbito da Organização Mundial do Comércio (OMC), em negociações recentemente realizadas, foi estabelecido o Acordo sobre Aplicação de Medidas Sanitárias e Fitossanitárias. Este acordo introduz novos conceitos que limitam a utilização de medidas fitossanitárias visando a evitar que aspectos fitossanitários irrelevantes sejam utilizados como barreiras não tarifárias ao comércio. A necessidade de utilização de 
medidas fitossanitárias menos restritivas e o incremento no mercado internacional de vegetais e seus subprodutos vem provocando nos países alterações da legislação, normas e procedimentos fitossanitários, com os objetivos de atender aos compromissos internacionais e de minimizar os riscos de introdução de pragas (Sgrillo, 1997).

Com os novos conceitos acordados pela OMC, algumas considerações podem ser efetuadas do ponto de vista da competitividade em função da questão sanitária. $\mathrm{O}$ volume de comércio internacional entre dois países será, em grande parte, função da credibilidade do pais exportador quanto à presença de pragas consideradas quarentenárias pelo país importador, da eficiência de seu sistema de quarentena e vigilância e de sua capacidade de oferecer um produto sadio (Gazzoni, 1997).

Um apreciável número de espécies de ácaros é fitófaga e pode alcançar o status de praga em ecossistemas agrícolas, florestais e pastoris. Os ácaros constituem algumas das principais pragas em várias culturas, sendo freqüentemente necessária a utilização de medidas de controle, o que leva a um aumento no custo de produção.

Os ácaros representam um grupo de grande importância quarentenária devido não só à importância econômica de diversas espécies, como à dificuldade de detecção destes organismos, por suas dimensões e localização no hospedeiro, podendo ser desapercebidamente transportados juntamente com o material vegetal. A importância dos ácaros ainda se deve à grande resistência a condições ambientes extremas de algumas espécies e ao potencial de desenvolvimento de resistência a pesticidas.

Apesar da importância econômica e quarentenária dos ácaros, pouco tem sido feito para evitar a introdução de espécies nocivas no Brasil, sendo necessário o emprego de esforços neste sentido.

É necessária uma revisão das espécies de ácaros que devem ser consideradas pragas de importância quarentenária para o Brasil. $\mathrm{Na}$ atual lista de pragas de importância quarentenária para o país, poucas são as espécies de ácaros citadas e não tem sido feita uma análise mais profunda sobre as espécies que realmente devem ser consideradas e quais devem ser acrescentadas.

Não se dispõe de técnicos adequadamente treinados para a inspeção acarológica de material vegetal, a qual deve ser extremamente minuciosa. Além disto, faltam 
profissionais treinados em taxonomia de ácaros, para que as espécies interceptadas sejam rápida e corretamente identificadas, o que é fundamental para a tomada de decisões em relação ao destino do material importado.

Há necessidade da realização de trabalhos para o estabelecimento de tratamentos quarentenários para eliminação de ácaros do material vegetal, o que pode ser extremamente importante para prevenir a introdução de espécies nocivas e para facilitar a exportação de produtos brasileiros. 


\section{REVISÃO DE LITERATURA - GERAL}

\subsection{Introdução de organismos nocivos através da atividade humana}

O movimento de pragas, patógenos e ervas daninhas de uma área infestada para uma não infestada pode se dar por meios naturais ou através da ação humana. A dispersão dos organismos, por meios naturais, a curtas ou longas distâncias, ocorre até que estes se deparem com uma barreira natural (Kahan, 1989). Entretanto, através da atividade humana os organismos nocivos podem se disseminar rapidamente ultrapassando estas barreiras.

De acordo com Foster (1991), os principais meios de introdução de pragas, são: passageiros, bagagens, veículos, material vegetal para consumo e propagação, germoplasma vegetal, introduções para fins científicos, vetores, cargas não agrícolas e embalagens.

Alimentos perecíveis ou processados, partes de plantas para propagação, material vegetal para decoração e lixo infestados podem ser transportados por passageiros em navios, aviões, e veículos rodo-ferroviários (Foster, 1991).

Frutas, verduras, flores para decoração, partes de plantas para análise ou processamento e produtos agrícolas refinados representam o maior volume de material vegetal importado. Corre-se o risco de que pragas presentes nestes materiais se dispersem ou sejam transferidas para hospedeiros próximos antes do material infestado ser utilizado. Embora em menor volume que o material vegetal para consumo, o material vegetal para propagação representa o maior risco de introdução de diversas pragas, pois fornece o maior número de habitats para estas se abrigarem (Foster, 1991). 
O volume dos produtos agrícolas comercializados entre os países é extremamente grande e vem aumentando progressivamente a cada ano (FAO, 1994). As possibilidades de veiculação de organismos nocivos associados a estes produtos também vêm aumentando.

Germoplasma vegetal se refere a materiais com gens ou combinações de gens únicos utilizados por melhoristas para desenvolver cultivares com características mais desejáveis. A maior variabilidade genética de uma espécie geralmente é encontrada em seu centro de origem. Infelizmente, os centros de origem das espécies vegetais correspondem aos locais onde a maior diversidade de espécies fitófagas a elas associadas é encontrada. Portanto, são muitas as possibilidades de se introduzir espécies exóticas juntamente com o material de interesse (Foster, 1991).

No Brasil, como na maioria dos países, grande parte das culturas de importância econômica é de origem exótica, resultado de introduções bem sucedidas. Portanto, para o desenvolvimento da agricultura no país são constantemente introduzidas novas variedades, que são utilizadas em programas de melhoramento genético. No período de 1976 a 1993, foram importados cerca de 140.800 germoplasmas vegetais, na forma de sementes, estacas, mudas, bulbos, tubérculos, rizomas etc, através do Centro Nacional de Pesquisa em Recursos Genéticos e Biotecnologia (CENARGEN), EMBRAPA. Além deste centro de pesquisa, outros órgãos como o Instituto Agronômico de Campinas (IAC), o Instituto Biológico (IB), a Copersucar, a Coordenadoria de Assistência Técnica Integral (CATI) e a Comissão Executiva do Plano da Lavoura Cacaueira (CEPLAC) também realizam a introdução e quarentena de germoplasma destinado ao Sistema de Pesquisa Agropecuária (SPA) (Marques et al., 1995).

Pragas de plantas podem ser introduzidas não somente através de material vegetal, solo, ou objetos inertes, mas também em associação com organismos que agem como vetores. Geralmente, as medidas quarentenárias são tomadas de acordo com o risco de introdução do vetor em si, não se considerando o que estes vetores podem estar carregando (Foster, 1991). 


\subsection{Quarentena vegetal}

A palavra "quarentena" é derivada do Latim "quadraginata" e do Italiano "quaranta", que significa quarenta. No Italiano, a palavra "quarantina" foi originalmente aplicada para o período de 40 dias de isolamento requerido para que um navio, incluindo seus passageiros e carga, permanecesse ancorado em um porto de chegada quando proveniente de um país onde ocorressem doenças epidêmicas, de modo a permitir o desenvolvimento e subseqüente detecção de sintomas nos passageiros antes do desembarque (Kahan, 1989).

Quarentena vegetal, literalmente, e por extrapolação, significaria o isolamento de plantas por 40 dias, como periodo de incubação para o aparecimento e deteç̧ão de sintomas de doenças. $\mathrm{Na}$ verdade, este procedimento constitui apenas uma fração das diversas ações que podem ser utilizadas em um programa de exclusão de organismos indesejáveis (Kahan, 1989).

A quarentena vegetal tem como objetivo prevenir a introdução de organismos nocivos em áreas isentas, utilizando a exclusão como estratégia no controle contra pragas e patógenos exóticos, sendo aplicada a produtos de importação e exportação (Kahan, 1989; Marques et al., 1995). A quarentena de produtos importados utiliza ações regulatórias para excluir pragas e patógenos que possam infestar ou contaminar artigos no país exportador. A quarentena de produtos para exportação utiliza procedimentos para proteger a agricultura dos países importadores, de acordo com os regulamentos ou condições especificadas por estes (Kahan, 1989).

O uso da exclusão para prevenir a introdução de uma determinada praga pode ser simplificado como um esforço para eliminar ou reduzir severamente sua população, através de medidas regulatórias, ao longo de sua trajetória de entrada (Foster, 1991).

O valor da quarentena vegetal não pode ser demonstrado experimentalmente (Neergard, $1977^{1}$ citado por Marques et al., 1995), mas pode ser avaliado em função das

1 NEERGARD, P. Quarantine policy for seed in transfer of genetic resources. In: HEWITT, W. B.; CHIARAPPA, L. Plant health and quarantine in international transfer of genetic resources. Cleeveland: CRC Press, 1977. p. 309-314. 
consequências desastrosas resultantes de introduções de pragas exóticas em áreas produtoras. Estas consequências podem ser de diversas naturezas, como danos e perdas de cultivos; perda de mercados de exportação pela presença de pragas de importância quarentenária no país; aumento dos gastos com controle de pragas; impacto sobre os programas de manejo integrado de pragas em execução ou em desenvolvimento; danos ambientes, pela freqüente necessidade de aplicação de defensivos para o controle da espécie introduzida; custos sociais, como desemprego, pela eliminação ou diminuição de um determinado cultivo em uma região; ou redução de fontes de alimento importantes para a população (Brasil, 1995).

\subsection{Medidas quarentenárias}

De acordo com o suplemento ao Diário Oficial $\mathrm{N}^{\circ} 195$, do Ministério da Agricultura, do Abastecimento e da Reforma Agrária (Brasil, 1995), medidas fitossanitárias se referem a "qualquer legislação, standard, diretriz, recomendação ou procedimento oficial que tem o propósito de prevenir a introdução e/ou disseminação de pragas quarentenárias, assim como o seu controle e erradicação".

Comumente as restrições quarentenárias impostas pelos regulamentos fitossanitários são consideradas como impedimento para o comércio internacional. Entretanto, a utilização de medidas quarentenárias coerentes quanto ao risco que representa a importação de cada produto pode facilitar a comercialização entre os países (Ganapathi, 1994).

As medidas quarentenárias comumente utilizadas são: inspeção fitossanitária e intercepção de pragas em pontos de entrada, quarentena de pós-entrada e proibição, restrição ou requisição de tratamentos quarentenários para a importação de produtos provenientes de países onde espécies de importância quarentenária são assinaladas. Podese também solicitar que os produtos sejam provenientes de áreas livres de pragas (Brasil, 1995). 
A inspeção fitossanitária é uma medida quarentenária que possibilita a intercepção de organismos nocivos associados ao material vegetal assim que este chega ao país. A inspeção do material vegetal também fornece algumas informações para se estimar o risco que representa a importação de um dado produto de um país ou região.

A identificação dos organismos detectados é de fundamental importância para se decidir o procedimento que deve ser adotado em relação ao material importado. Quando pragas quarentenárias são detectadas durante a inspeção de produtos, uma das três ações seguintes é normalmente tomada: realização de tratamentos, devolução do lote importado ao pais de origem, ou destruição dos produtos infestados (Baker et al., 1993).

Para que um tratamento seja considerado um quarentenário, todos os organismos associados ao material vegetal devem receber doses letais sem que o material seja danificado. São poucos os tratamentos que podem realmente alcançar os altos niveis de controle exigidos pelos regulamentos quarentenários. Tratamentos quarentenários efetivos podem auxiliar a evitar o movimento de pragas e doenças e facilitar as restrições impostas para a importação de produtos vegetais provenientes de países onde ocorrem pragas de importância quarentenária (MacDonald \& Mills, 1994).

\subsection{Pragas de importância quarentenária}

As medidas quarentenárias são baseadas nas listas de pragas de importância quarentenária formuladas para cada país ou para grupos de países geograficamente próximos.

Por definição, uma praga quarentenária é um organismo de importância econômica potencial para a área posta em perigo e onde ainda não está presente ou, se está, não se encontra amplamente distribuida e está sob controle oficial (Brasil, 1995).

Populações de uma determinada espécie que apresentam características biológicas particulares, distinguindo-se por isto das demais populações de sua espécie, são denominadas biótipos. Biótipos de uma espécie resistentes a pesticidas, mais nocivos ou que apresentem hospedeiros distintos também são considerados pragas de importância 
quarentenária, mesmo que a espécie seja assinalada e apresente ampla distribuição no país (Baker et al., 1993).

Cada vez mais, enfatiza-se a importância dos países justificarem seus regulamentos fitossanitários. A meta atual é que os serviços de quarentena aprimorem o processo utilizado para identificar quais as pragas para as quais barreiras fitossanitárias são justificáveis, isto é, que apresentam importância quarentenária, em meio aos milhares de organismos contra os quais medidas fitossanitárias não podem ser biologicamente sustentadas. Por isto, o processo para determinação de quais as espécies que devem ser consideradas pragas quarentenárias deve ser claro e consistente (Hopper, 1991).

Para decidir quais as espécies a serem definidas pragas de importância quarentenária para um país ou região, uma série de informações deve ser considerada (EPPO, 1993a). É necessário avaliar o potencial das espécies exóticas em causar prejuízos no país em questão. Este processo é o componente preliminar da Análise de Risco de Pragas (ARP) (Baker et al.. 1993; Hopper, 1991 e 1993).

\section{5. Ácaros - Importância agrícola}

Os ácaros mostram uma considerável variação em sua estrutura interna e externa e no modo de vida, podendo ser encontrados nos mais variados ambientes (Flechtmann, 1975, 1985). Entre os ácaros, existem formas endo e ectoparasitas de vertebrados e invertebrados, e formas de vida livre. Entre as formas de vida livre encontram-se as espécies de importância agrícola.

As espécies fitófagas podem tornar-se pragas em sistemas agrícolas. A maioria das espécies fitófagas pertence à subordem Prostigmata, e às famílias Eriophyidae, Tetranychidae, Tenuipalpidae e Tarsonemidae (Flechtmann, 1985). Em algumas outras famílias - Penthaleidae, Pyemotidae, Tydeidae e Tuckerellidae - também encontram-se espécies fitófagas de importância econômica.

Alguns ácaros infestam produtos armazenados causando danos diretos ou indiretos. Os danos diretos consistem no consumo de uma parte não desprezível dos 
produtos para sua alimentação, levando a uma redução no peso dos mesmos e na destruição do embrião, afetando o poder germinativo de sementes e o valor nutritivo dos grãos. Os danos indiretos se devem principalmente ao aumento da dispersão de microrganismos, depreciação do valor comercial do produto pela simples presença dos ácaros, alteração no sabor e odor dos alimentos, problemas à saúde humana e de animais. Os principais ácaros que infestam produtos armazenados pertencem à subordem Astigmata, famílias Acaridae, Glycyphagidae, Chortoglyphidae, Histiostomidae, Carpoglyphidae, Pyroglyphidae e Winterschmidtiidae (Flechtmann, 1986).

Além dos danos diretos, os ácaros podem agir como vetores ou disseminadores de fitopatógenos. Espécies pertencentes às famílias Eriophyidae e Tenuipalpidae podem transmitir agentes causais de doenças de plantas, como o mosaico do alho e o mosaico da cebola por Aceria tulipae (Keifer) (Hiruki, 1992; Slykhuis, 1980) e a leprose dos citros por Brevipalpus phoenicis (Geijskes) (Colariccio et al, 1995). Outras espécies disseminam fungos patogênicos, como Fusarium por Siteroptes graminum Reuter (Alford et al., 1976; Simons, 1971), ou Verticillium albo-atrum por Rhizoglyphus echinopus (Foumouze \& Robin) (Price, 1976).

Em várias culturas, os ácaros constituem hoje pragas importantes e os gastos com o controle destas espécies-praga são significativos. Como exemplo, no Brasil, temos a utilização de acaricidas em pomares de citros para o controle de Phyllocoptruta oleivora (Ashmead), ácaro da falsa ferrugem, e Brevipalpus phoenicis (Geijskes), ácaro da leprose. Apesar dos avanços nas práticas de manejo, ainda hoje os gastos com estes produtos representam mais de $50 \%$ dos gastos com insumos nesta cultura (Gravena, 1994).

Apesar da importância dos ácaros para a agricultura brasileira, poucos são os dados disponíveis em relação às perdas ocasionadas pelas infestações. Algumas avaliações foram realizadas para algodão, feijão e mandioca .

Os resultados de trabalhos realizados por Oliveira (1972), relacionados ao efeito de infestações do ácaro rajado, Tetranychus urticae Koch em algodoeiros, mostraram que podem causar uma redução de até $25 \%$ na produção, $12 \%$ em número de sementes, 
$4 \%$ no teor de matéria graxa das sementes, $17 \%$ no peso das fibras, $13 \%$ na espessura das fibras e $4 \%$ na resistência das fibras.

No Brasil, o ácaro branco, Polyphagotarsonemus latus (Banks), é uma das principais pragas de algodão e feijão. Este ácaro pode causar uma redução de até $11 \%$ na produção algodoeira e levar à depreciação de algumas características importantes das fibras, como redução de 5\% na espessura e 3\% na resistência das fibras (Oliveira \& Calcagnolo, 1974). Em feijoeiro constatou-se uma redução de até $47 \%$ na produção de grãos quando a infestação ocorreu na fase inicial da cultura (Omoto \& Nakano, 1988).

No estado de Pernambuco foram observadas perdas de até $51 \%$ no rendimento da cultura da mandioca devido à infestação pelo ácaro verde da mandioca, Mononychellus tanajoa (Bondar) (Veiga, 1985).

É notável o aumento recente dos problemas de importância econômica causados pelos ácaros, principalmente em espécies frutíferas, hortícolas e algumas culturas extensivas (Doreste, 1988).

Um dos fatores que têm contribuido para o aumento dos problemas com ácaros em culturas onde utiliza-se o controle químico é o desenvolvimento de resistência em populações de ácaros-praga a inseticidas e acaricidas (Saito et al., 1983). O desenvolvimento de resistência a pesticidas é um grande entrave em programas de controle de pragas, pois leva à aplicação mais freqüente, ao aumento das dosagens dos produtos e à substituição por outros, geralmente de maior toxicidade. Estes fatores comprometem o manejo integrado de pragas (MIP) devido à maior contaminação do ambiente, à destruição de organismos benéficos e à elevação nos custos de controle da praga (Omoto, 1997).

Georghiou \& Mellon (1983) relataram a ocorrência de resistência a pesticidas em 29 espécies de ácaros fitófagos pertencentes às famílias Eriophyidae, Tenuipalpidae e Tetranychidae. É de se esperar que este número seja hoje muito maior. A maioria das espécies é resistente a organofosforados, entretanto, diversas espécies têm apresentado resistência a outros grupos de compostos.

Um alto nível de resistência a muitos compostos em populações de ácaros pode se desenvolver após somente 1- 4 anos de uso de um determinado produto, inclusive com o 
aparecimento de resistência cruzada. Alguns dos fatores que contribuem para isto são alto potencial reprodutivo, ciclo de vida muito curto, fertilização cruzada, macho haplóide e altas taxas de mutação (Saito et al., 1983).

Ácaros tetraniquídeos têm demonstrado a abilidade de tornarem-se resistentes a todas as categorias de acaricidas orgânicos (Dennehy et al., 1990). As espécies para as quais há fortes evidências de resistência múltipla a acaricidas são Panonychus citri (McGregor), Panonychus ulmi (Koch), T. urticae, Tetranychus kanzawai (Kishida) e Tetranychus mcdanieli McGregor. As espécies que têm desenvolvido resistência a um maior número de grupos de acaricidas são P. ulmi e T. urticae (Cranham \& Helle, 1985).

$\mathrm{O}$ progressivo aumento da resistência e a tendência de um menor número de acaricidas entrarem no mercado a cada ano tem resultado em uma escassez de produtos efetivos para muitas culturas agrícolas (Dennehy et al., 1990).

\section{6. Ácaros - Importância quarentenária}

Além da importância econômica dos ácaros, algumas características deste grupo de organismos realçam sua importância quarentenária.

De uma maneira geral, os ácaros são bastante pequenos e, aqueles pertencentes à Eriophyoidea e Tarsonemoidae, estão entre os menores artrópodos conhecidos, medindo de 100 a $300 \mu \mathrm{m}$ (Flechtmann, 1985).

A inspeção acarológica de material vegetal deve ser extremamente detalhada, pois os ácaros comumente encontram-se em locais protegidos. Algumas espécies do gênero Rhyzoglyphus Claparède, pragas de bulbos e tubérculos, alojam-se entre as escamas das camadas mais internas dos bulbos ou em fissuras dos tubérculos (Hughes, 1976). Ácaros eriofídeos podem se desenvolver no interior das gemas, entre os tecidos em formação dos hospedeiros (Flechtmann, 1985). O período de tempo necessário para detecção de infestações latentes de eriofiídeos que se desenvolvem em gemas é bastante longo. Verma \& Kapur (1990), referindo-se à quarentena de fruteiras de climas áridos, aconselham a 
observação do material por um período de 1 a 3 estações e Diekmann et al. (1994), a pequenas frutas do gênero Ribes, por pelo menos 10 meses.

Além disto, em alguns produtos os ovos de ácaros normalmente não são detectados. Amostras de cereais nas quais não foram detectados ácaros em uma inspeção preliminar mostraram-se infestadas após um período de incubação, devido à presença inicial de ovos (Baggio et al., 1987).

Apesar da agricultura representar uma atividade extremamente importante no Brasil e dos sérios problemas enfrentados em outros países com ácaros-praga que ainda não ocorrem aqui, atualmente, somente 3 espécies de ácaros são listadas como pragas de importância quarentenária para o Brasil : Acarus siro L., Tetranychus pacificus McGregor e Brevipalpus lewisi McGregor (Brasil, 1995).

\subsection{Problemas ocasionados pela introdução de novas espécies de ácaros}

A introdução do ácaro verde da mandioca, $M$. tanajoa, na África representa um exemplo bastante claro do quão desastrosa pode ser a introdução de uma espécie exótica em uma área de produção, quando são encontradas condições favoráveis ao seu desenvolvimento e ausência de inimigos naturais.

A mandioca (Manihot esculenta), originária da América do Sul, foi introduzida na África no século XVI por comerciantes portugueses onde se tornou uma importante fonte de carboidratos para 300 a 500 milhões de pessoas (Byrne et al., 1983), sendo cultivada nas áreas tropicais de $15^{\circ} \mathrm{N}$ a $20^{\circ} \mathrm{S}$. A mandioca é resistente a condições de baixa umidade e foi por muito tempo considerada resistente a pragas e doenças (Janssen \& Yaninek, 1993).

M. tanajoa, é um dos ácaros mais importantes da cultura (Byrne et al., 1983). Este ácaro foi introduzido acidentalmente em Kampala, Uganda, em 1971, através de material vegetal proveniente da América do Sul. Atualmente este ácaro encontra-se em quase toda a África tropical, levando a perdas de até $80 \%$ na produção (Herren \& Neuenschwander, 1991; Janssen \& Yaninek, 1993). 
O controle químico do ácaro verde da mandioca é inviável, devido às próprias condições em que a mandioca é cultivada na África, isto é, em pequenas propriedades para subsistência da população. Iniciou-se, então, em 1980, um projeto de controle biológico e resistência de plantas, coordenado pelo "International Institute of Tropical Agriculture" (IITA), com a colaboração de pesquisadores e instituições da África, Europa e América. Inicialmente, o projeto de controle biológico caminhou a passos lentos, devido, em parte, à carência de informações sobre a ecologia e biologia da praga, pois os problemas na sua área de distribuição natural não eram tão sérios. 0 programa de controle biológico do ácaro verde da mandioca na África é um dos projetos de controle biológico mais caros no mundo, tendo custado, até o momento, aproximadamente 10 milhões de dólares (Moraes²).

Além da introdução do ácaro verde da mandioca na África existem diversos exemplos de introduções de ácaros pragas em áreas isentas onde passaram a causar sérios problemas.

No Brasil, como exemplo, temos a introdução do ácaro vermelho europeu, P. ulmi. Atualmente esta espécie constitui uma das principais pragas da macieira no país. É possivel que o ácaro vermelho europeu tenha sido introduzido no Brasil através de frutos infestados, como alertado por Flechtmann (1967), o qual detectou um grande numero de ácaros desta espécie em quase todas as frutas de um lote de maçãs importadas da Argentina em uma casa comercial de Piracicaba, São Paulo. Em 1972, observou-se uma grande infestação de ácaros posteriormente identificados como $P$. ulmi em pomares de maçã de Fraiburgo, Santa Catarina (Bleicher, 1974). Este foi o primeiro relato da praga no Brasil.

No passado, não se tinha preocupação com o trânsito de material vegetal pois não se conhecia muito a respeito de problemas fitossanitários, conseqüentemente, um grande número de ácaros deve ter sido introduzido descuidadamente. Características de distribuição geográfica e espectro de hospedeiros podem indicar a região de origem de uma determinada espécie (Gutierrez ,1974).

${ }^{2}$ MORAES, G. J. de (Pesquisador CNPq, Dept. Zoologia - Escola Superior de Agricultura "Luiz de Queiroz" - Piracicaba - SP - Brasil). Comunicação pessoal, 1996. 
Muitas vezes, as espécies que apresentam indicações de terem sido introduzidas são aquelas de maior importância econômica para uma dada cultura. Por exemplo, em Madagascar e ilhas vizinhas foram relatadas 14 espécies do gênero Tetranychus, e somente 5 destas apresentam importância econômica apreciável: Tetranychus neocaledonicus André, T. urticae, Tetranychus evansi Baker \& Pritchard, Tetranychus macfarlanei Baker \& Pritchard e Tetranychus fijiensis Hirst. Segundo Gutierrez (1974), considerando as características das espécies, as 4 últimas citadas parecem ter sido introduzidas pelo homem.

\subsection{Intercepção de ácaros em material vegetal}

Muitas vezes, são detectados ácaros em material vegetal importado, na ocasião da inspeção fitossanitária realizada pelos serviços de defesa vegetal de diferentes países. Algumas vezes, as espécies detectadas são novas para a ciência ou ainda não foram assinaladas no pais ou região em que foram interceptadas. Especialmente nestes casos, a inspeção fitossanitária mostra-se como uma medida extremamente importante que desencadeia uma série de outras medidas para impedir o estabelecimento de espécies ainda não assinaladas no país.

Sete espécies do gênero Rhizoglyphus Claparède foram interceptadas em material vegetal entrando na Nova Zelândia a partir de diversos países (Anexo A, Tabela 1). Destas espécies, seis foram identificadas como novas (Manson, 1972a). Neste gênero encontram-se importantes pragas da porção subterrânea de plantas.

Nos Estados Unidos da América do Norte (EUAN) o "Food and Drug Administration" (FDA) inspeciona os alimentos importados que entram através da Califórnia, para deteç̧ão de contaminantes, incluindo ácaros. Olsen (1983) listou as 22 espécies de ácaros detectadas nas 212 amostras de grãos e cereais inspecionadas, no período de setembro de 1980 a agosto de 1982, provenientes principalmente de países

orientais (Anexo A, Tabela 2). Os ácaros detectados pertencem aos gêneros Acarus L., Aleuroglyphus Zachvatkin, Caloglyphus Berlese, Carpoglyphus Robin, Chortoglyphus 
Berlese, Dermatophagoides Bogdanoff, Euroglyphus Fain, Lepidoglyphus Zachvatkin, Suidasia Oudemans, Thyreophagus Rondani e Tyrophagus Oudemans.

Diversas espécies das famílias Tetranychidae e Tenuipalpidae foram detectadas em material vegetal interceptado nos portos e aeroportos da Nova Zelândia no período de 1958 a 1966 (Anexo A, Tabela 3). Entre estas, uma identificada como espécie nova foi descrita como Eotetranychus queenslandicus Manson e três outras ainda não haviam sido assinaladas na Nova Zelândia - Schizotetranychus baltazarae Rimando, Temuipalpus pacificus Baker e T. neocaledonicus (Manson, 1967).

Oito espécies de ácaros tetraniquídeos foram interceptadas em abóboras importadas pela "Yokohama Plant Protection Station", no Japão, sendo que cinco delas pertencentes ao gênero Tetranychus ainda não tinham sido assinaladas naquele país (Anexo A, Tabela 4) (Masaki et al., 1991).

Ácaros pertencentes a 4 subordens, 35 famílias e 87 espécies foram interceptados pelo serviço de quarentena vegetal do Japão, em "Yokohama Plant Protection Station", até o ano de 1993 (Anexo A, Tabelas 5 e 6) (Masaki, 1991; Kaneda, 1993).

Na Holanda, sete espécies de Tetranychidae, uma de Penthalodidae e uma de Eriophyidae, foram interceptadas pelo serviço de proteção vegetal no período de 1992 a 1994 (Anexo A, Tabela 7). Entre elas, Tetranychus tumidus Banks praga séria de vegetais e ornamentais, foi detectada em plantas de Phoenix importadas de Cuba; e um eriofiídeo, Aceria sp., detectado em Zelkova bonsais importada que apresentava manchas vermelhas nas folhas, provavelmente causadas pela infestação do ácaro, foi designado como uma nova espécie (Ackerman et al., 1994 e 1995).

Em 1978, em casa de vegetação na Grã-Bretanha, Panonychus citri (McGregor) foi detectado infestando Citrus mitis importado dos EUAN. Os ácaros estavam infestando a superficie superior das folhas, causando bronzeamento e descoloração. Este foi o primeiro registro da espécie em casas de vegetação naquele país e a população foi erradicada através de pulverizações de produtos químicos (Bowman \& Barlett, 1978).

Algumas espécies novas de tetraniquídeos foram interceptadas em estações de quarentena dos EUAN. Atacando cacau, Theobroma cacao, proveniente de Trinidad foi interceptada em Washington uma espécie nova nomeada Tetranychus nakahari Baker \& 
Tuttle (Baker \& Tuttle, 1976). Infestando Agave sp. e Dasylirion sp., provenientes do México, foi interceptada no Texas uma espécie nova designada Petrobia mexicana Baker \& Tuttle (Baker \& Tuttle, 1983). Bryobia eharai Pritchard \& Keifer foi interceptada em Chrysantemum importado do Japão e Paquistão (Pritchard \& Keifer, 1958).

Phyllocoptes acuminatus Manson espécie nova da família Eriophyidae, foi descrita e coletada de folhas de Codiaeum sp. interceptado pela quarentena do Oeste de Samoa e Fiji, provenientes da Nova Zelândia (Manson, 1972b).

Em levantamento realizado da acarofauna de produtos alimentícios importados na Polônia constatou-se que quase $21 \%$ das amostras continham ácaros. Das 34 espécies detectadas, 14 não haviam sido assinaladas naquele país. As espécies consideradas de importância potencial caso se estabelecessem no país foram: Suidasia medanensis Oudemans, Suidasia nesbitti Hughes, Lardoglyphus konoi (Sasa \& Asanuma), Histiogaster carpio (Kramer), Histiogaster bacchus Zkhv. e Blomia tjibodas (Oudemans) (Chmielewski, 1972).

Surpreendentemente, ácaros também podem ser detectados em materiais industrializados ou semi-industrializados. Representantes dos gêneros Rhizoglyphus Claparède, Tyrophagus Oudemans e Schwiebea Oudemans foram detectados em carregamentos de pneus usados importados da Ásia, na África do Sul, quando estes estavam sendo inspecionados visando a intercepção do mosquito Aedes albopictus, espécie de importância médica (Cornel \& Hartwig, 1989). Uma nova espécie da família Triplogyniidae, designada Triplogynium ligniphilum Wisniewski \& Hirschmann foi descrita a partir de espécimens introduzidos na Polônia sobre madeira de Entandrophragma cylindricum importada de Camarões (Wisniewski \& Hirschmann, 1993). 


\section{AVALIAÇ̃̃o da IMPORTÂNCIA QUARENTENÁRIA dE ÁCARos ASSOCIADOS A CULTURAS FRUTIFERAS PARA O BRASIL}

\subsection{INTRODUÇÃO}

A fruticultura é uma atividade bastante importante no Brasil, apresentando um grande potencial de desenvolvimento devido à extensão do território brasileiro e à diversidade de condições climáticas, podendo-se cultivar fruteiras de clima temperado e tropical.

Apesar da elevada produção de frutas frescas no Brasil e da quase totalidade da produção ser destinada ao mercado interno, grandes volumes são importados, principalmente de frutas de clima temperado, incluindo maçã, uva, pêssego, pêra, ameixa e figo (Brasil, 1994). Além da importação de frutas frescas, o Brasil importa mudas, em escala comercial, de algumas destas culturas (Brasil, 1996).

Sérias pragas podem ser introduzidas no país através da importação de frutas e mudas de frutiferas, causando prejuízos às culturas sobre as quais foram introduzidas ou a outras, de igual ou maior importância econômica.

Os ácaros representam importantes pragas em diversas culturas de frutiferas de clima tropical e temperado, sendo necessária a aplicação de medidas de controle, que levam a um aumento no custo de produção. Como exemplo, no Brasil, temos a utilização de acaricidas em citros, para o controle de Phyllocoptruta oleivora (Ashmead), ácaro da falsa ferrugem, e Brevipalpus phoenicis (Geijskes), ácaro da leprose. Apesar dos 
avanços nas práticas de manejo, ainda hoje os gastos com estes produtos representam mais de $50 \%$ dos gastos com insumos nesta cultura (Gravena, 1994).

Os problemas causados por ácaros em culturas agrícolas vêm aumentando (Doreste, 1988). Um dos fatores que têm contribuido para o aumento dos problemas com ácaros em culturas onde utiliza-se o controle químico é o desenvolvimento de resistência a inseticidas e acaricidas (Saito et al., 1983).

Problemas de resistência a acaricidas têm sido relatados principalmente em culturas como frutíferas e algodão, na Europa, América do Norte, sul da África, China e Japão (Cranham \& Helle, 1985). No Brasil, são poucos os trabalhos relatando o desenvolvimento de resistência a acaricidas em populações de ácaros-praga em frutíferas e os níveis de resistência não têm sido altos. Portanto, é importante evitar a introdução de biótipos de ácaros-praga associados a frutíferas que sejam resistentes a acaricidas.

Desta maneira, devem-se utilizar medidas quarentenárias para prevenir a introdução de novas espécies ou biótipos de ácaros que poderão causar ou intensificar os problemas a culturas frutíferas no país.

No presente momento, a atualização da legislação fitossanitária e o fortalecimento do serviço de quarentena vegetal é de fundamental importância para a proteção do setor agrícola e para o desenvolvimento econômico do país, devido a acordos internacionais sobre comércio entre países e entre blocos econômicos.

A legislação fitossanitária tem como referência principal a lista de pragas de importância quarentenária para o país. Atualmente é necessário que o processo para determinação de pragas de importância quarentenária seja claro e consistente; este procedimento corresponde à etapa inicial da Análise de Risco de Praga (ARP) (Hopper, 1991).

A ARP consiste na análise das possibilidades de transferência de uma praga de um país a outro e à sua adaptação no local de destino (Sutherst., 1991). Este procedimento considera as características bioecológicas das espécies para avaliar seu potencial de causar prejuizos de importância econômica no país (Baker et al.. 1993; European and Mediterranean Plant Protection Organization, 1993a; Hopper, 1991 e 1993). 
Apesar da importância econômica e quarentenária dos ácaros, pouco tem sido feito para evitar a introdução de espécies nocivas, sendo necessário o emprego de esforços neste sentido. É necessária uma revisão das espécies de ácaros que devem ser consideradas pragas de importância quarentenária para o país. Não tem sido feita uma análise mais profunda sobre as espécies que realmente devem ser consideradas e quais devem ser acrescentadas à lista de pragas quarentenárias.

O presente trabalho tem como objetivo avaliar a importância quarentenária para o Brasil de ácaros associados a culturas frutíferas de importância econômica no país, cuja importação de frutos ou material para propagação vegetativa represente risco de introdução de espécies ou biótipos nocivos de ácaros não assinalados no país. 


\subsection{REVISÃO DE LITERATURA}

\subsubsection{Produção e comercialização de frutas no Brasil}

A fruticultura, apesar de ocupar apenas 5\% das áreas cultivadas no país, é uma das atividades capazes de assegurar ao Brasil um percentual significativo do volume de produção global, colocando-o em primeiro lugar entre os produtores de frutas in natura (Brasil, 1994). As fruteiras de maior importância no Brasil, considerando o valor da produção são citros, banana, abacaxi, uva, côco-da-Bahia, maçã e mamão, entretanto, outras também são produzidas em grandes quantidades (Tabela 1) (Anuário Estatístico do Brasil, 1997).

Tabela 1. Produção de culturas frutíferas no Brasil.

\begin{tabular}{|l|r|r|r|}
\hline \multicolumn{1}{|c|}{ Cultura } & Area colhida (ha) & Quantidade (t) & Valor (1000 R\$) \\
\hline Citros & 990.133 & 99.315 .841 & 2.857 .316 \\
\hline Banana & 516.087 & 572.619 & 662.231 \\
\hline Abacaxi & 45.218 & 989.551 & 298.625 \\
\hline Uva & 60.251 & 807.520 & 272.458 \\
\hline Côco-da-Bahia & 237.038 & 918.822 & 242.579 \\
\hline Maçã & 27.112 & 3.499 .675 & 180.914 \\
\hline Mamão & 29.078 & 1.181 .173 & 159.722 \\
\hline Maracujá & 33.487 & 3.167 .574 & 143.614 \\
\hline Manga & 55.444 & 1.728 .302 & 127.860 \\
\hline Melancia & 72.213 & 149.321 & 106.015 \\
\hline Pêssego & 19.765 & 1.361 .874 & 79.799 \\
\hline Goiaba & 7.841 & 1.283 .188 & 68.052 \\
\hline Abacate & 14.933 & 410.574 & 44.483 \\
\hline Melão & 11.506 & 108.582 & 39.887 \\
\hline Caqui & 4.605 & 554.062 & 35.372 \\
\hline Figo & 2.178 & 298.825 & 15.306 \\
\hline Pêra & 2.284 & 126.052 & 7.724 \\
\hline
\end{tabular}

Fonte: Anuário Estatístico do Brasil (1997) 
O Brasil destina cerca de $1 \%$ da sua produção total de frutas frescas para exportação. As principais frutas exportadas são maçã, laranja, banana, melão e uva . 0 principal mercado importador de frutas brasileiras é a Comunidade Européia e o Mercosul (Tabela 2) (Brasil, 1994).

Tabela 2. Destino das exportações brasileiras de frutas frescas por grandes blocos em 1992.

\begin{tabular}{|l|r|r|r|r|r|r|r|}
\hline \multirow{2}{*}{ Fruta } & \multicolumn{2}{|c|}{$\begin{array}{c}\text { América do Norte } \\
\text { EUAN }\end{array}$} & \multicolumn{2}{c|}{ Europa } & Mercosul & Outros & Total \\
\hline Maçã & -- & 334,73 & $20.578,45$ & 88,69 & 21,80 & 27,39 & $\mathbf{2 1 . 0 5 1 , 0 6}$ \\
\hline Laranja & -- & 8,13 & $15.132,35$ & -- & 10,20 & $3.556,35$ & $\mathbf{1 8 . 7 0 7 , 0 3}$ \\
\hline Melão & 228,11 & 145,91 & $13.477,91$ & $1.198,86$ & $1.610,43$ & 2,50 & $\mathbf{1 6 . 6 6 3 , 7 2}$ \\
\hline Banana & --- & -- & 1,85 & -- & $16.660,82$ & -- & $\mathbf{1 6 . 6 6 2 , 6 7}$ \\
\hline Uva & -- & 373,51 & $5.156,35$ & 73,47 & $2.055,05$ & 3,92 & $7.662,30$ \\
\hline Manga & $1.224,52$ & 196,80 & $5.118,35$ & 199,22 & 135,61 & 0,72 & $\mathbf{6 . 8 9 5 , 2 0}$ \\
\hline Abacaxi & -- & --- & 138,33 & - & $5.131,63$ & 2,50 & $\mathbf{5 . 2 7 2 , 4 0}$ \\
\hline Mamão & 0,76 & 27,70 & $1.896,93$ & 451,28 & 70,98 & 2,89 & $\mathbf{2 . 4 5 0 , 5 0}$ \\
\hline Tangerina & --- & 224,88 & $1.627,54$ & -- & - & 168,40 & $\mathbf{2 . 0 2 0 , 8 0}$ \\
\hline Limão & -- & 3,74 & $1.535,50$ & 13,79 & -- & 3,74 & $\mathbf{1 . 5 5 6 , 7 0}$ \\
\hline TOTAL & $1.473,39$ & $1.315,40$ & $64.663,56$ & $2.025,31$ & $25.696,52$ & $3.768,41$ & $\mathbf{9 8 . 9 4 2 , 5 9}$ \\
\hline
\end{tabular}

Fonte: Brasil (1994)

${ }^{1}$ valores em US\$ 1.000

Entre as frutas que são exportadas pode-se identificar um grupo de frutas "tradicionais" - banana, laranja e abacaxi - com peso ainda dominante nas exportações, mas apresentando taxas de crescimento pequenas ou até negativas nos últimos 15 anos. $O$ outro grupo, composto por manga, mamão, melão, maçã e uva, apresentou crescimento acelerado no mesmo período, porém partindo de quantidades muito pequenas. Este último grupo detém as melhores perspectivas a médio e longo prazos nos principais mercados importadores (Brasil, 1994).

$O$ volume anual de importação de frutas oscilou de 100.000 a 170.000 t/ano, no período de 1986 a 1991 (Brasil, 1994). As frutas importadas em maiores volumes e 
freqüências, considerando o período de janeiro de 1992 a agosto de 1996, foram: maçã, pêra, ameixa, uva, nectarina e pêssego (Tabela 3) (Brasil, 1996).

Tabela 3. Importação de frutas frescas de janeiro de 1992 a agosto de 1996 pelo Brasil.

\begin{tabular}{|c|c|c|c|c|c|c|c|c|c|c|c|c|}
\hline \multirow[t]{2}{*}{ CULTURA } & \multicolumn{2}{|c|}{1992} & \multicolumn{2}{|c|}{1993} & \multicolumn{2}{|c|}{1994} & \multicolumn{2}{|c|}{1995} & \multicolumn{2}{|l|}{1996} & \multicolumn{2}{|l|}{ Total } \\
\hline & $\mathbf{Q}$ & $\mathbf{N}^{\circ} \mathbf{L}$ & $\mathbf{Q}$ & $\mathbf{N}^{0} \mathbf{L}$ & $\mathbf{Q}$ & $\mathbf{N}^{\circ} \mathbf{L}$ & $\mathbf{Q}$ & $\mathbf{N}^{\mathbf{D}} \mathbf{L}$ & $\mathbf{Q}$ & $\mathbf{N}^{\circ} \mathbf{L}$ & $\mathbf{Q}$ & $\mathbf{N}^{\circ} \mathbf{L}$ \\
\hline Macã & 484.5 & 10 & 5.371 .5 & 97 & $365.888,3$ & 120 & 32.857,0 & 221 & $7.519,6$ & 44 & $412.115,7$ & 489 \\
\hline Pera & $10.849,2$ & 20 & $3.260,7$ & 67 & $8.849,5$ & 110 & $32.234,1$ & 235 & $13.683,5$ & 122 & $68.877,0$ & 554 \\
\hline Ameixa & $48.286,2$ & 12 & 600,4 & 36 & 1311,6 & 53 & 2368,5 & 115 & 1532,3 & 158 & $54.099,0$ & 374 \\
\hline Uva & $14.164,3$ & 11 & $4.082,9$ & 35 & 698,9 & 29 & $16.290,1$ & 88 & 715,6 & 85 & $35.951,8$ & 248 \\
\hline Nectarina & $12.826,6$ & 14 & $9.134,4$ & 37 & 423,0 & 45 & 994,1 & 98 & 873,7 & 137 & $24.251,8$ & 331 \\
\hline Pêssego & $7.943,4$ & 15 & $9.780,1$ & 38 & 475,8 & 59 & $1.993,8$ & 134 & 741,3 & 172 & $20.934,4$ & 418 \\
\hline Melão & 0,5 & 1 & $14.198,5$ & 12 & 20,5 & 5 & 3,1 & 8 & 2,1 & 4 & $14.224,7$ & 30 \\
\hline Kiwi & & & $1.654,6$ & 42 & $1.021,8$ & 36 & $4.605,8$ & 51 & 442,3 & 11 & $7.724,5$ & 140 \\
\hline Cereja & 141,1 & 15 & 248,7 & 19 & 238,7 & 35 & 404,1 & 42 & 71,8 & 70 & $1.104,5$ & 181 \\
\hline Citros & 89,3 & 4 & 48,2 & $\overline{2}$ & 109,5 & 8 & 269,6 & 8 & & & 516,6 & 22 \\
\hline Morango & 0,005 & 2 & 0,5 & 1 & 38,6 & 26 & 290,8 & 102 & 13,9 & 22 & 343,8 & 153 \\
\hline Melancia & & & 0,43 & 1 & & & 25,8 & 1 & 124,4 & 1 & 150,7 & 3 \\
\hline Manga & & & 55,2 & 7 & & & 50,9 & 6 & & & 106,1 & 13 \\
\hline Banana & 4 & 10 & 23,8 & 3 & 37,5 & 1 & & & & & 65,3 & 14 \\
\hline Caqui & & & & & 3,1 & 1 & 54,0 & 11 & & & 57,1 & 12 \\
\hline Grapefruit & & & & & & & 40,0 & 1 & & & 40,0 & 1 \\
\hline
\end{tabular}

Fonte: Brasil (1996)

${ }^{1} \mathrm{Q}$ - quantidade total em toneladas; $\mathrm{N}^{\circ} \mathrm{L}$ - número total de lotes importados

Além de frutas frescas, o Brasil vem importando material para propagação de macieiras e videiras. No período de janeiro de 1992 a agosto de 1996 foram importadas 336.835 mudas de macieiras e 110.698 mudas de videiras (Brasil, 1996). 


\subsubsection{Importância dos ácaros em culturas frutíferas}

Em levantamento realizado por Yaninek \& Moraes (1991), considerando as 19 principais culturas agrícolas, escolhidas como representantes da agriculrura mundial, as culturas às quais estão associados um maior número de ácaros-praga são citros, algodão, uva, maçã, feijão e mamão. Observa-se que dentre estas 6 culturas, 4 são frutíferas (Tabela 4).

Tabela 4. Número de espécies de ácaros-praga associados à culturas agrícolas, por gêneros.

\begin{tabular}{|c|c|c|c|c|c|c|}
\hline Família/Gênero & Citros & Algodão & Uva & Maçã & Feijão & Mamão \\
\hline \multicolumn{7}{|l|}{ Tetranychidae } \\
\hline Tetranychus & 2 & 11 & 3 & 6 & 7 & 4 \\
\hline Panonychus & 1 & & 1 & 1 & & \\
\hline Oligonychus & & 2 & 1 & & 1 & 1 \\
\hline Eutetranychus & 5 & & & & & \\
\hline Eotetranychus & 3 & 1 & 4 & 3 & & 1 \\
\hline Schizotetranychus & 1 & & & & & \\
\hline Bryobia & & & & 1 & & \\
\hline Petrobia & & 1 & & & & \\
\hline \multicolumn{7}{|l|}{ Eriophyidae } \\
\hline Phytoptus & & & & 1 & & \\
\hline Eriophyes & 1 & & & & 1 & \\
\hline Aculus & & & & 1 & & \\
\hline Colomerus & & & 1 & & & \\
\hline Acalitus & & 1 & & & & \\
\hline Aculops & 1 & & & & & \\
\hline Calacarus & 1 & & & & & 2 \\
\hline Calepitrimerus & & & 1 & & & \\
\hline Phyllocoptruta & 1 & & & & & \\
\hline \multicolumn{7}{|l|}{ Tenuipalpidae } \\
\hline Brevipalpus & 4 & 1 & 2 & & & \\
\hline \multicolumn{7}{|l|}{ Tarsonemidae } \\
\hline Polyphagotarsonemus & 1 & 1 & 1 & & 1 & 1 \\
\hline Total & 21 & 18 & 14 & 13 & 10 & 9 \\
\hline
\end{tabular}

Fonte: Yaninek \& Moraes (1991) 
No Brasil, são vários os ácaros que causam problemas a frutíferas. Podem-se destacar Phyllocoptruta oleivora (Ashmead) e Brevipalpus phoenicis (Geijskes) em citros; Eriophyes guerreronis Keifer em côco; Tetranychus urticae Koch e Panonychus ulmi (Koch) em maçã; Polyphagotarsonemus latus (Banks) em mamão; Eriophyes mangiferae (Sayed) em manga; Dolichotetranychus floridanus (Banks) em abacaxi e T. urticae e P. latus em uva (Flechtmann, 1985; Kovaleski \& Vendramim, 1993; Monteiro, 1994).

O desenvolvimento de resistência a pesticidas é um sério problema em programas de controle de pragas (Omoto, 1997). Entre as culturas agrícolas, as frutíferas são umas das que mais têm apresentado problemas de resistência de ácaros a acaricidas, devido à intensa pressão de seleção (Cranham \& Helle, 1985).

Principalmente na Europa, América do Norte, sul da África, China e Japão tem sido relatada a resistência de populações de ácaros a 2 ou mais grupos de acaricidas ou a organofosforados. $P$. ulmi e $T$. urticae são as espécies que apresentam resistência a um maior número de grupos de acaricidas (Cranham \& Helle, 1985).

No Brasil, poucos trabalhos têm sido realizados para avaliar a resistência a pesticidas em populações de ácaros. Chiavegato et al. (1983) relataram a ocorrência de populações de T. urticae em áreas de produção algodoeira resistentes a monocrotofós. A susceptibilidade de populações de T. urticae coletadas de rosas da Holambra-São Paulo e de videiras de Pilar do Sul-Rio Grande do Sul aos acaricidas dimetoato, cihexatina, propargite, naled e mevinfós foi avaliada, comparando-a à de populações de matas nativas. A população coletada em rosas foi cerca de 4 vezes menos susceptível a dimetoato e naled que a da mata. A população coletada em videiras foi 5 vezes mais resistente a dimetoato que a coletada em mata. Entretanto, houve pouca diferença na susceptibilidade aos outros acaricidas entre as duas populações (Souza Filho et al., 1994; Takematsu et al., 1994).

Os níveis de resistência apresentados por populações de $T$. urticae coletadas no Brasil podem ser considerados baixos. Em outros paises, têm sido relatados níveis de resistência a acaricidas bastante altos. Como exemplo, a resistência de populações de T. urticae a cihexatina na Austrália, coletadas em pêra e maçã, alcançou 15 vezes quando 
comparado ao de uma população de vegetação natural (Edge \& James, 1986). Na Coréia foi relatado um nível de resistência a propargite de 30 vezes em população de $T$. urticae coletado em maçã (Park et al., 1986).

\subsubsection{Possibilidades de introdução de ácaros através da importação de frutas ou mudas de frutíferas.}

Ácaros são facilmente veiculados através de frutos ou mudas de frutíferas. Em frutos, ácaros podem ser detectados principalmente em rugosidades, fendas ou reentrâncias na casca, sob brácteas ou na proximidade do pecíolo. Em mudas, pode-se encontrar ácaros em todas as porções das plantas, como folhas, gemas e caules.

Ácaros podem ser encontrados em frutos no campo e persistir associados a estes mesmo após a colheita, embalagem e transporte. Em levantamento realizado em Taiwan, em média, $10 \%$ dos cachos de uva de 8 de 10 parreirais avaliados encontraram-se infestados por T. urticae (Ho \& Chen, 1994). Avaliou-se a presença de artrópodos em cerca de 326.625 frutos de nectarina, já embalados para comercialização, na Califórnia, EUAN. Entre as 17 espécies de ácaros ou insetos de importância econômica detectados, T. pacificus foi encontrado em incidência relativamente alta (10-60 ácaros/100.000 frutos) (Curtis et al., 1992). B. phoenicis foi interceptado em frutos de citros provenientes de ilhas do Pacífico e África do Sul chegando na Nova Zelândia (Manson, 1967).

Muitas vezes é necessária a realização de tratamentos quarentenários antes da exportação de frutos para eliminação de formas viáveis de ácaros-praga presentes nestes. No Canadá, testes têm sido realizados para avaliar a efetividade de fumigantes para eliminação de ovos de $P$. ulmi e adultos de Tetranychus mcdanieli McGregor em frutos de maçã (Herne \& Bond, 1981; Sanford et al., 1976). Cerca de 4 a 5 milhões de dólares são gastos anualmente com a fumigação de frutos de kiwi exportados da Nova Zelândia para o Japão para o controle de T. urticae (Baker \& Cowley, 1989). Experimentos 
utilizando atmosferas controladas para o tratamento de uvas, para eliminação de T. pacificus e outras pragas foram realizados nos EUAN (Ahumada et al., 1996).

No Brasil, são poucos os relatos de intercepção de ácaros em frutos ou mudas de frutíferas importadas. Um lote de mudas de macieiras importadas da Argentina, em 1958, encontrava-se fortemente infestado por Bryobia rubrioculus (Scheuten), e, em alguns enxertos, as posturas eram numerosas nas proximidades das gemas e na inserção dos ramos; também foram encontradas formas jovens. O material foi desinfestado e mantido em quarentena por 12 meses (Figueiredo, 1950). Em um caso recente, em junho do presente ano, vários lotes de pêssegos, nectarinas e damascos importados dos EUAN foram interceptados no Aeroporto Internacional de Guarulhos - São Paulo, por estarem infestados por T. pacificus (Flechtmann ${ }^{3}$ ).

\subsubsection{Problemas causados pela introdução de ácaros-praga associados a culturas frutíferas}

No Brasil, a maioria das espécies de frutíferas cultivadas foi introduzida e, provavelmente, diversas espécies de ácaros-praga associados a estas culturas são espécies exóticas, introduzidas acidentalmente.

Muitas vezes, quando uma espécie exótica de ácaro é detectada em uma região ou país, sua distribuição já é ampla, o que impossibilita a implantação de um programa de erradicação.

Na África do Sul, o ácaro vermelho europeu, $P$. ulmi, foi encontrado pela primeira vez em um pomar de maçãs próximo a Grabouw. Um levantamento mostrou que a espécie já estava presente em mais de 14 das 101 fazendas na região de Elgin. A infestação já se encontrava em um estágio além do qual a erradicação poderia ser tentada, e apenas pôde-se empregar esforços para evitar uma maior dispersão da praga (Giliomee \& Pringle, 1972).

${ }^{3}$ FLECHTMANN, C. H. W. (Pesquisador CNPq - Dept. Dept. Zoologia - Escola Superior de Agricultura "Luiz de Queiroz" - Piracicaba - SP - Brasil). Comunicação pessoal, 1997. 
Colônias do eriofídeo Aculops pelekassi (Keifer) foram detectadas em plântulas de laranjeira em dezembro de 1961 na Flórida, EUAN. Não se sabe exatamente desde quando a praga estava presente no país, nem de que maneira foi introduzida, mas havia indicações de que teria ocorrido muito tempo antes de seu primeiro registro. Um programa de erradicação de $A$. pelekassi foi então iniciado nos locais onde a espécie havia sido detectada, mas verificou-se que espécie já se encontrava amplamente distribuida, dificultando a erradicação (Denmark, 1962).

No Brasil, como exemplo, temos a introdução do ácaro vermelho europeu, P. ulmi. Atualmente, esta espécie constitui uma das principais pragas da macieira no país, causando perdas devido à queda precoce das folhas, redução do tamanho dos frutos, do vigor da planta e da produção em anos subseqüentes ao ataque da praga. (Kovaleski \& Vendramim, 1993). Além da diminuição da produção, esta praga pode levar à restrição da importação de frutos brasileiros, pelo fato da espécie ser considerada uma praga de importância quarentenária por diversos países, como México e Cuba (FAO, 1993; Kahan, 1989).

É possível que o ácaro vermelho europeu tenha sido introduzido no Brasil através de frutos infestados, como alertado por Flechtmann (1967). Em 1967, quando P. ulmi ainda não havia sido assinalado no Brasil, grande quantidade de ovos viáveis desta espécie foram detectados em quase todas as frutas de um lote de maçãs importadas da Argentina, mantidas sob refrigeração em uma casa comercial de Piracicaba - São Paulo. Os ácaros encontravam-se na região de inserção do pedúnculo e na região oposta à este, onde se encontra uma pequena câmara formada pelos restos da flor, sendo contados até cerca de 500 ovos por fruto (Flechtmann, 1967). Na ocasião, o autor alertou quanto ao risco de se introduzir a praga no país desta maneira. Em 1972, observou-se uma grande infestação de ácaros posteriormente identificados como $P$. ulmi em pomares de maçã de Fraiburgo - Santa Catarina (Bleicher, 1974). Este foi o primeiro relato da praga no Brasil. 


\subsection{5. Ácaros de importância quarentenária associados a culturas frutíferas.}

Apesar da grande diversidade e importância econômica das culturas frutíferas no Brasil e dos sérios problemas enfrentados em outros países com ácaros-praga que ainda não ocorrem no país, atualmente, somente 2 espécies de ácaros associados a frutíferas são consideradas pragas de importância quarentenária para o Brasil (Tabela 5) (Brasil, 1995).

Quase todos os ácaros considerados pelo Comitê de Sanidade Vegetal do Cone Sul (COSAVE) de importância quarentenária para os países do Cone Sul são associados a frutiferas (Tabela 5) (Brasil, 1995).

Tabela 5. Ácaros de importância quarentenária para o COSAVE e países integrantes.

\begin{tabular}{|c|c|c|}
\hline & Espécie & Hospedeiros \\
\hline \multicolumn{3}{|l|}{ COSAVE } \\
\hline & Brevipalpus lewisi McGregor & citros, videira, pistache \\
\hline & Tetranychus pacificus McGregor & videira e outras frutíferas, algodão \\
\hline \multicolumn{3}{|l|}{ Argentina } \\
\hline & Brevipalpus califormicus Banks & citros, videira \\
\hline & Brevipalpus lewisi McGregor & citros, videira, pistache \\
\hline & Steneotarsonemus pallidus (Banks) & morango \\
\hline & Tetranychus pacificus McGregor & videira e outras frutíferas, algodão \\
\hline \multicolumn{3}{|c|}{ - } \\
\hline & Acarus siro L. & grãos armazenados \\
\hline & Brevipalpus lewisi McGregor & citros, videira e pistache \\
\hline & Tetranychus pacificus McGregor & videira e outras frutíferas, algodão \\
\hline \multicolumn{3}{|l|}{ Chile } \\
\hline & Halotydeus destructor (Tucker) & trevo \\
\hline & Tetranychus pacificus McGregor & videira e outras frutíferas \\
\hline \multicolumn{3}{|l|}{ Paraguai } \\
\hline & Brevipalpus californicus Banks & citros, videira \\
\hline & Brevipalpus lewisi McGregor & citros, amendoim, videira \\
\hline & Oligonychus perwvianus McGregor & hortaliças \\
\hline & Tetranychus pacificus McGregor & algodão, videira e outras frutíferas \\
\hline \multicolumn{3}{|l|}{ Uruguai } \\
\hline & Brevipalpus californicus Banks & citros, videira \\
\hline & Brevipalpus lewisi McGregor & $\begin{array}{l}\text { citros, videira, pistache, } \\
\text { ornamentais }\end{array}$ \\
\hline & Tetranychus pacificus McGregor & $\begin{array}{l}\text { videira e outras frutíferas, algodão, } \\
\text { leguminosas, , curcubitáceas }\end{array}$ \\
\hline
\end{tabular}

Fonte: Brasil (1995) 
É importante conhecer quais as espécies listadas como pragas de importância quarentenária por outros países ou grupos de países. Esta é uma das informações utilizada na ARP (European and Mediterranean Plant Protection Organization, 1993a), pois fornece uma indicação de quão séria é a espécie ou o quão importantes podem ser outras espécies do mesmo gênero. Ademais, devem-se tomar cuidados especiais para evitar a introdução de espécies listadas como quarentenárias por outros países, pois isto pode levar à perda de mercados de exportação.

Holdeman (1986) ${ }^{4}$ citado por Kahan (1989) apresenta as listas de pragas quarentenárias de diversos países, no ano de 1986, nas quais. encontram-se 41 espécies de ácaros pertencentes a 16 gêneros. As espécies citadas por Kahan (1989) associadas a frutíferas estão contidas na Tabela 6 . Outras espécies de importância quarentenária para diversos países e Organizações de Proteção Vegetal Regionais (RPPO's), também associadas a frutíferas estão apresentadas na Tabela 7.

Tabela 6. Ácaros de importância quarentenária associados a frutíferas.

\begin{tabular}{|c|c|c|}
\hline Familia & Espécie & Principais Hospedeiros \\
\hline \multicolumn{3}{|l|}{ Eriophyidae } \\
\hline & Aculus fockeui (Nalepa \& Trouessart) & ameixa e cereja \\
\hline & Cecidophyopsis ribis (Westwood) & Ribes sp. \\
\hline & Eriophyes pyri (Pagenstecher) & pomáceas \\
\hline \multicolumn{3}{|l|}{ Tenuipalpidae } \\
\hline & Brevipalpus chilensis Baker & videira, frutiferas, ornamentais \\
\hline & Cenopalpus pulcher (Canestrini \& Fanzago) & frutíferas \\
\hline \multicolumn{3}{|l|}{ Tetranychidae } \\
\hline & Eotetranychus sexmaculatus (Riley) & citros, várias árvores e arbustos \\
\hline & Panonychus ulmi (Koch) & frutiferas decíduas e árvores florestais \\
\hline & Tetranychus urticae Koch & mais de 150 culturas \\
\hline
\end{tabular}

Fonte: Holdeman (1986) ${ }^{4}$ citado por Kahan (1989).

\footnotetext{
${ }^{4}$ HOLDEMAN, Q. (Ed.) Plant pests of phytosanitary significance to importing countries and states.
} 5.ed. Sacramento: California Department of Food and Agriculture, 1986. 
Tabela 7. Ácaros de importância quarentenária para diversos países e "Regional Plant Protection Organizations" (RPPO's) associados a frutíferas.

\begin{tabular}{|c|c|c|c|}
\hline Espécie & País ou RPPO & $\begin{array}{c}\text { Status } \\
\text { Quarent }\end{array}$ & Fonte \\
\hline Aceria guerreronis Keifer & APPPC $^{5}$ & $\overline{\mathrm{Al}}$ & FAO (1993) \\
\hline Aceria sheldoni (Ewing) & JUNAC $^{3}$ & $\overline{\mathrm{Al}}$ & FAO (1993) \\
\hline Amphitetranychus viennensis (Zacher) & América do Norte & Al & Kahan (1989) \\
\hline Brevipalpus australis (Tucker) & COSAVE $^{4}$ & Al & FAO (1993) \\
\hline Brevipalpus lewisi McGregor & COSAVE $^{4}$ & $\mathrm{Al}$ & FAO (1993) \\
\hline Cenopalpus pulcher (Can. \& Fan.) & América do Norte & Al & Kahan (1989) \\
\hline Eotetranychus lewisi (McGregor) & $\mathrm{EU}^{6}$ & $\overline{\mathrm{Al}}$ & Roy $^{5}$ \\
\hline Eutetranychus orientalis (Klein) & $\begin{array}{l}\text { OIRSA }^{1}, \mathrm{CPPC}^{2}, \text { América } \\
\text { do Norte, } \mathrm{EU}^{6}\end{array}$ & Al & $\begin{array}{l}\text { FAO (1993), Kahan } \\
\text { (1989), Roy }\end{array}$ \\
\hline Panonychus ulmi (Koch) & México e Cuba & Al & FAO (1993) \\
\hline Tetranychus pacificus McGregor & COSAVE $^{4}$ & $\overline{\mathrm{Al}}$ & FAO (1993) \\
\hline \multicolumn{4}{|c|}{ 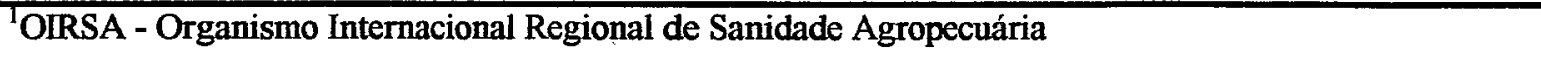 } \\
\hline \multicolumn{4}{|c|}{${ }^{2}$ CPPC - Comissão de Proteção Vegetal do Caribe } \\
\hline \multicolumn{4}{|l|}{${ }^{3}$ JUNAC - Junta do Acordo de Cartagena } \\
\hline \multicolumn{4}{|c|}{${ }^{4}$ COSAVE - Comitê de Sanidade Vegetal do Cone Sul } \\
\hline \multicolumn{4}{|c|}{${ }^{5}$ APPPC - Comissão de Proteção Vegetal da Ásia e Pacífico } \\
\hline${ }^{6} \mathrm{EU}$ - Organização Européia & & & \\
\hline
\end{tabular}

\subsubsection{Determinação de pragas de importância quarentenária - Análise de Risco de Pragas.}

Por definição, uma praga quarentenária é um organismo de importância econômica potencial para a área posta em perigo e onde ainda não está presente ou, se está, não se encontra amplamente distribuida e é oficialmente regulada. Considera-se praga quarentenária A1 aquela que não está presente no país ou região. Praga

\footnotetext{
${ }^{5}$ ROY, A. S. (Setor de informações EPPO - Paris - França) Comunicação pessoal, 1996.
} 
quarentenária A2 é aquela que apresenta distribuição limitada em uma área e é oficialmente controlada (Brasil, 1995).

Populações de uma determinada espécie que apresentam características biológicas particulares, distinguindo-se, por isto, das demais populações de sua espécie são denominadas biótipos. Biótipos de uma espécie resistentes a pesticidas, mais nocivos ou que apresentem hospedeiros distintos também são considerados pragas de importância quarentenária, mesmo que a espécie seja assinalada e apresente ampla distribuição no país (Baker et al., 1993).

Para decidir as espécies a serem definidas pragas de importância quarentenária para um país ou região, uma série de informações deve ser considerada (European and Mediterranean Plant Protection Organization, 1993a). É necessário avaliar o potencial das espécies exóticas em causar prejuízos no país em questão. Este processo é o componente preliminar da ARP (Baker et al., 1993; Hopper, 1991 e 1993).

A ARP consiste em duas partes principais: Avaliação do Risco de Pragas e Manejo do Risco de Pragas. A primeira parte trata da identificação e caracterização das pragas quarentenárias e consiste na análise da possibilidade de transferência da praga de um país a outro e à sua adaptação no local de destino. A segunda parte se refere à seleção de opções de manejo apropriadas e tecnicamente justificáveis para minimizar o risco de introdução e estabelecimento da espécie na área posta em perigo (Figura 3.1) (Singh, 1996; Sutherst., 1991). Somente realizando uma detalhada ARP pode-se selecionar estratégias adequadas para enfrentar a ameaça de introdução de organismos nocivos (Baker, 1994).

A ARP é essencial para países importadores revisarem seus regulamentos fitossanitários e assegurarem que estes são justificáveis e o menos restritivos possível ao comércio internacional. Além disto, é uma ferramenta poderosa para identificar lacunas no conhecimento científico, indicando linhas de pesquisa a serem priorizadas (Singh, 1996).

O primeiro passo para a avaliação da importância quarentenária das espécies é a elaboração de uma ficha contendo as informações sobre sua biologia, distribução geográfica, plantas hospedeiras, potencial de estabelecimento, medidas de controle 
disponíveis, formas de transporte e dispersão e importância econômica (European and Mediterranean Plant Protection Organization, 1993a).

Para a realização da ARP pode-se utilizar respostas escritas, dendogramas de decisões, sistema de notas ou estimativas de probabilidades (Baker et al., 1993; Baker \& Bailey, $1979^{6}$ in Baker, 1994; European and Mediterranean Plant Protection Organization, 1993b).

Para que uma praga seja considerada de importância quarentenária deve apresentar potencial de importância econômica, potencial de introdução e potencial de estabelecimento (Brasil, 1995).

A avaliação do potencial de impacto econômico da praga em uma etapa inicial possibilita que a análise do risco seja interrompida logo que se constate que se trata de uma espécie de pouca importância, evitando, desta maneira, trabalho desnecessário (Baker et al., 1993).

O potencial que uma praga apresenta de causar danos de importância econômica depende basicamente da importância econômica e/ou social de seus hospedeiros no país em risco; da seriedade dos problemas acarretados ou das perdas causadas devido às infestações nos países onde a espécie ocorre; da disponibilidade, eficiência e custo das medidas de controle utilizadas para a espécie; do status quarentenário da espécie, especialmente nos países importadores de produtos pelos quais a praga pode ser veiculada e dos efeitos indesejáveis das medidas de controle normalmente utilizadas sobre o ambiente (Brasil, 1995; European and Mediterranean Plant Protection Organization, 1993a; Hopper, 1991).

O potencial de introdução de uma praga em uma área isenta depende das possibilidades de infestação dos produtos importados nos países de origem, da sobrevivência da praga às condições de transporte do material e de ser detectada na ocasião da chegada dos produtos no pais importador (Brasil, 1995; European and Mediterranean Plant Protection Organization, 1993a; Hopper \& Campbell, 1989; Sutherst., 1991).

${ }^{6}$ BAKER, C. R. B.; BAILEY, A. G. Assessing the threat to British crops from alien diseases and pests. In: EBBELS, D. L.; KING, J. E. (Ed.) Plant health. Oxford: Blackwell Scientific Publications, 1979. p. 43-54. 
ANÁLISE DE RISCO DE PRAGAS

posição taxonômica biologia

distribuição geográfica

hospedeiros

impacto econômico

medidas de controle

\section{AVALIAC̄̃O DO RISCO DE PRAGAS}
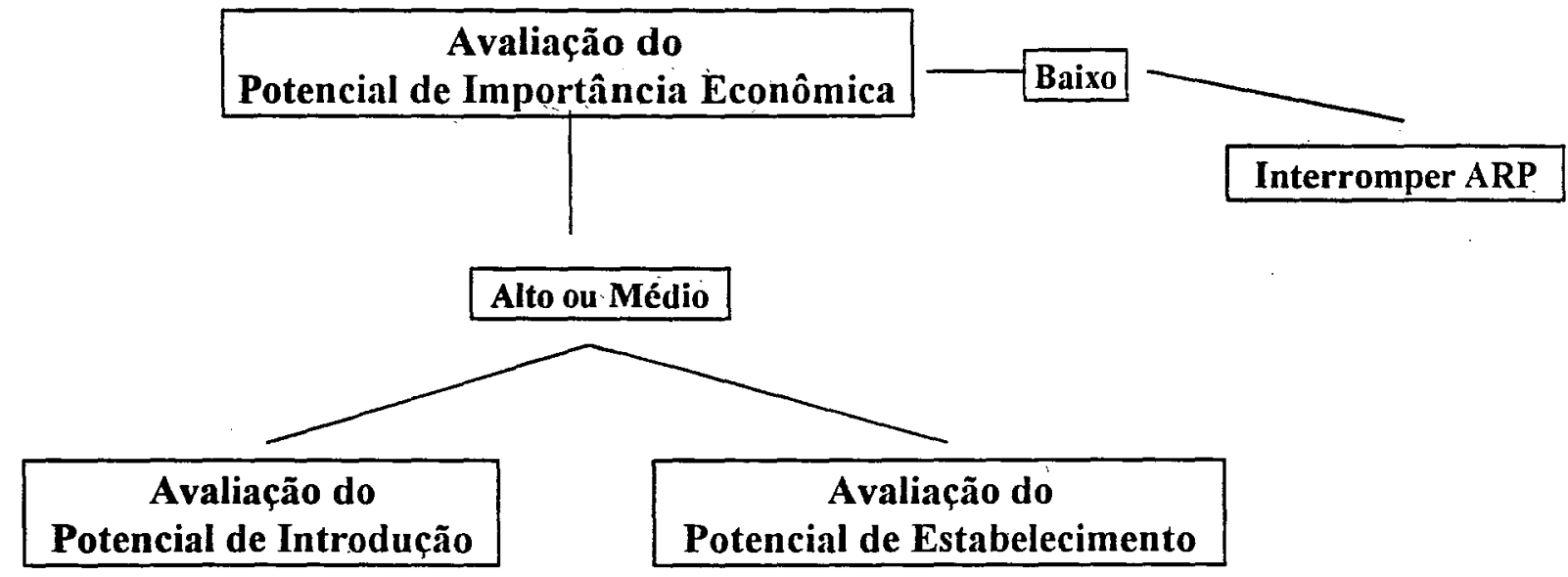

Alto ou Médio

1

MANEJO DO RISCO DE PRAGAS

Figura 3.1. Diagrama da Análise de Risco de Pragas 
A avaliação do potencial de estabelecimento das pragas é um dos procedimentos mais complexos na ARP, pois envolve muitos fatores (Baker \& Bailey, 1979 in Baker, 1994; European and Mediterranean Plant Protection Organization, 1993a).

Ao chegar a um novo destino, as espécies-pragas encontram um novo ambiente. Para se estabelecer, necessitam de condições climáticas favoráveis, disponibilidade de plantas hospedeiras, ausência de competição severa e outras necessidades fisicas, como abrigo ou tipos de solo específicos (Sutherst, 1991).

Um dos primeiros problemas com que uma praga imigrante se defronta é o clima no momento de sua chegada. Caso sobreviva para produzir uma nova progênie, a próxima questão é se a espécie sobreviverá à próxima estação desfavorável. A praga poderá se estabelecer no ponto de entrada ou poderá imediatamente ser transportada para outras áreas com condições climáticas mais favoráveis. Deve-se avaliar as áreas de risco de colonização e se o clima possibilitará às espécies a constituir populações economicamente importantes. Para avaliar estes pontos, deve-se comparar o clima das áreas onde a espécie ocorre com o da área posta em perigo (Sutherst, 1991).

Para avaliar o potencial de estabelecimento de espécies imigrantes considerando fatores climáticos foi desenvolvido na Austrália o sistema denominado CLIMEX. Este sistema permite a análise das possibilidades de estabelecimento das espécies em diferentes regiões sem a necessidade de dados completos sobre a biologia das espécies. Os criadores do programa assumiram que o macro-clima é o fator mais importante limitando a distribuição geográfica dos artrópodos em seus continentes de origem, bem como a fenologia e abundância relativa das espécies em qualquer região (Sutherst et al., 1991).

Para a avaliação do potencial de estabelecimento de pragas Baker (1994) sugere a utilização de mapas de risco, onde dados sobre os fatores climáticos que influenciam o desenvolvimento das pragas devem ser comparados entre estações meteorológicas e ligados a modelos fenológicos. Novas ferramentas estatísticas para sistemas de informação geográfica e análises espaciais fornecem os procedimentos necessários para a contrução destes mapas. Quando se dispõe de poucas informações sobre os fatores limitantes à distribuição e desenvolvimento das pragas, mas sua distribuição é conhecida, bancos de dados climáticos podem ser utilizados na avaliação do potencial de 
estabelecimento por possibilitarem a comparação de climas de regiões onde a espécie ocorre e não ocorre (Baker, 1994).

Apesar das sofisticadas metodologias que vêm sendo empregadas na ARP em países desenvolvidos, em países menos desenvolvidos deve-se proceder às análises utilizando as ferramentas disponíveis. Qualquer procedimento que venha a ser padronizado oficialmente deve levar em consideração as limitações dos países menos desenvolvidos, sendo simples, prático e aplicável com um mínimo de tecnologia e requerimento de dados (M'Boob, 1993). 


\subsection{METODOLOGIA}

\subsubsection{Seleção de culturas}

Foram utilizados os dados disponíveis no Sistema de Controle de Importação e Exportação (SIMEX), desenvolvido pelo Ministério da Agricultura, Abastecimento e Reforma Agrária - MAARA (atualmente Ministério da Agricultura e Reforma Agrária), sobre importação de frutas e mudas de frutíferas no período de janeiro de 1992 a agosto de 1996, sua quantidade, procedência e destino. Também foram utilizados dados sobre a importância econômica das culturas no país, disponíveis em anuários estatísticos.

Os parâmetros utilizados para a seleção das culturas frutíferas com que se trabalhou foram:

\# volume e/ou frequência das importações

\# importância econômica da cultura no Brasil

$\rightarrow$ importância dos ácaros como pragas da cultura

\# possibilidade de veiculação de ácaros fitófagos pela parte da planta ou produto importado

\subsubsection{Seleção das espécies de ácaros cuja importância quarentenária foi avaliada}

Foram alistadas as espécies de ácaros que causam problemas às culturas escolhidas e que são assinaladas nos países exportadores de produtos potencialmente infestados para o Brasil, de acordo com informações disponiveis em SIMEX (Brasil, 1996). Destacaram-se as espécies não assinaladas no Brasil e aquelas que, embora presentes no país, apresentam biótipos distintos em outros países. 


\subsubsection{Avaliação da importância quarentenária das espécies alistadas}

Nesta etapa do trabalho, as espécies de ácaros alistadas na etapa anterior foram consideradas individualmente.

Antes de iniciar a avaliação da importância quarentenária dos ácaros, foram consultadas informações sobre sua posição taxonômica, sinônimos, dificuldades ou confusões na classificação e relações com outras pragas quarentenárias. Também com base na lista de informações requeridas para a ARP da European and Mediterranean Plant Protection Organization (1993b), foram registradas informações sobre características biológicas, distribuição geográfica, hospedeiros, métodos de controle, impacto econômico e meios de transporte (dispersão/disseminação).

O detalhamento e sofisticação da avaliação da importância quarentenária das espécies foi proporcional à disponibilidade de informações sobre estas. Para algumas espécies de pragas foram encontradas informações suficientes para proceder uma análise de risco detalhada. Para outras, também importantes, foram encontrados poucos dados sobre biologia e ecologia.

A avaliação da importância quarentenária das espécies foi realizada seguindo os critérios adotados pela FAO (1995). Avaliou-se o potencial de impacto enconômico, de introdução e de estabelecimento dos ácaros-praga no Brasil. Esta avaliação foi qualitativa e subjetiva, classificando-se os potenciais em alto, médio ou baixo.

Primeiramente, avaliou-se o potencial de importância econômica das espécies, considerando-se os seguintes parâmetros:

\# $\rightarrow$ importância econômica ou social dos hospedeiros da praga no país

$\#$ danos e perdas causadas pela praga nos países onde ocorre

$\rightarrow$ medidas utilizadas para o controle da espécie - disponibilidade, eficiência, custo e impacto ambiental das medidas

Em todas as avaliações, considerou-se que a necessidade de aplicação de pesticidas para o controle da espécie leva a um aumento no custo de produção e pode causar ou agravar problemas ambientes. 
¥ importância quarentenária da espécie em outros países

Em uma etapa posterior, foi avaliado o potencial de introdução das pragas que apresentaram elevado potencial de importância econômica, considerando-se os seguintes parâmetros:

$\pitchfork$ possibilidade de infestação do produto importado no país de origem - abundância da praga no país exportador; volume, freqüência e época dos embarques dos produtos que podem estar infestados pela praga.

\# capacidade de sobrevivência da praga às condições de transporte dos produtos que podem estar infestados - condições de umidade e temperatura durante o transporte, uso proposto do produto.

Material para propagação vegetativa normalmente é transportado e mantido em condições ideais para que não se danifique e possa se desenvolver bem. Estas condições favorecem também a sobrevivência dos organismos que o acompanham. Portanto, quando uma das vias de ingresso das pragas no país foi através de mudas, considerou-se alta sua capacidade de sobrevivência às condições de transporte do produto.

\# possibilidade de deteç̧ão da praga nos produtos potencialmente infestados dimensões e localização da praga no hospedeiro; sintomas apresentados na planta/produto devido às infestações; eficiência do serviço de quarentena vegetal do pais.

Considerou-se que sintomas da infestação normalmente surgem quando as populações atingem um determinado nível populacional, ou após um período de alimentação dos ácaros. Desta maneira, os sintomas podem sinalizar a presença dos ácaros, mas sua ausência não significa ausência de infestação.

Para todas as ARP's, na análise deste parâmetro, considerou-se baixa a eficiência do serviço de quarentena vegetal no Brasil para deteç̧ão de ácaros em material vegetal, pois há uma carência de técnicos adequadamente treinados com este fim. 
Em uma etapa final, avaliou-se o potencial de estabelecimento das espécies que apresentaram potencial de introdução médio ou alto. Consideraram-se os seguintes parâmetros:

\# disponibilidade de hospedeiros para a praga no Brasil - distribuição e abundância dos hospedeiros da praga principalmente nas regiões de chegada e destino dos produtos potencialmente infestados.

$\#$ adequação das condições climáticas brasileiras para a sobrevivência, desenvolvimento e reprodução da praga - condições favoráveis e fatores limitantes ao desenvolvimento da espécie.

Não foram comparadas detalhadamente as condições climáticas brasileiras com as das regiões onde as espécies ocorrem. As espécies avaliadas ocorrem, em sua maioria, em países com invernos rigorosos e passam estas estações em diapausa, desenvolvendo-se normalmente somente quando a temperatura começa a aumentar. Portanto, de uma maneira geral, considerou-se que as condições climáticas brasileiras, onde os invernos não são tão rigorosos, são favoráveis ao desenvolvimento das espécies. Casos especiais, como preferência por climas amenos ou por determinadas faixas de umidade relativa do ar foram discutidos.

\# potencial reprodutivo (fecundidade, número de gerações por ano).

$\rightarrow$ uso proposto do material vegetal potencialmente infestado. Quando os produtos infestados são destinados à propagação vegetativa, o potencial de estabelecimento das espécies a ele associados é maior. $O$ destino final do material para propagação é o ambiente onde serão cultivados ou multiplicados, o que aumenta as possibilidades de que os organismos que estejam veiculando se estabeleçam na área, diferentemente do material cujo uso proposto é consumo, pois estes tem que se dispersar para o ambiente e encontrar um hospedeiro antes de que os produtos a que estão associados sejam consumidos, para que possam se estabelecer. 
De uma maneira geral, não se dispõe de informações detalhadas sobre dispersão em ácaros (velocidade, distâncias por ano, etc). As espécies utilizam-se de fatores naturais (vento, presença de vetores) para se dispersar. Portanto, este parâmetro não foi avaliado detalhadamente.

Para as análises dos potenciais de introdução e estabelecimento das espécies foram considerados os dados sobre importações brasileiras de produtos vegetais não industrializados de janeiro de 1992 a agosto de 1996, disponíves em SIMEX (Brasil, 1996).

Não foi avaliado o potencial de estabelecimento das espécies já assinaladas no Brasil que apresentam biótipos distintos em outros países. 


\subsection{RESULTADOS E DISCUSSÃO}

\subsubsection{Culturas selecionadas}

As culturas frutíferas selecionadas, considerando os critérios propostos foram maçã e uva.

Como pode-se observar na Tabela 3, as frutas importadas em maiores volumes no período de janeiro de 1992 a agosto de 1996 foram maçã, pêra, ameixa, uva, nectarina e pêssego. Além destas frutas serem importadas em grandes quantidades, a frequência das importações também foi bastante alta. Ademais, entre as frutíferas, maçã e uva foram as únicas culturas que tiveram mudas importadas em grandes quantidades neste mesmo período (Brasil, 1996).

Entre as culturas cujos frutos foram importados em maiores volumes e em frequências mais altas, maçã e uva também estão entre as seis de maior importância econômica no país, considerando o valor da produção (Tabela 1) (Anuário Estatístico do Brasil, 1997). Além do valor da produção, estão entre as culturas cujos frutos têm apresentado peso dominante na pauta das exportações e cujas exportações vêm crescendo aceleradamente. Em 1992, maçã foi a fruta que apresentou maior valor de exportações, rendendo ao país US\$21,1 milhões (Brasil, 1994).

De acordo com a revisão realizada por Yaninek \& Moraes (1991), baseada em vasta literatura e experiências pessoais, maçã e uva estão entre as cinco culturas agrícolas que apresentam maior número de ácaros-praga associados.

São grandes as possibilidades de veiculação de ácaros através da importação de frutos ou mudas de maçãs e uvas. 
3.4.2 Espécies cuja importância quarentenária foi avaliada

Avaliou-se a importância quarentenária de 11 espécies de ácaros associadas à cultura da maçã e 10 associadas à uva, sendo que 5 destas espécies foram comuns entre as culturas (Tabela 8). Entre as 16 espécies avaliadas, somente 2 já ocorrem no Brasil e apresentam biótipos distintos em outros países - Tetranychus urticae Koch e Panonychus ulmi (Koch).

Tabela 8. Ácaros-praga associados às culturas de maçã/uva cuja importância quarentenária foi avaliada.

\section{ESPÉCIE}

Aculus schlechtendali (Nalepa, 1890)

Amphitetranychus viennensis (Zacher, 1920)

Brevipalpus chilensis Baker, 1949

Brevipalpus lewisi McGregor, 1949

Bryobia rubrioculus (Scheuten, 1857)

Cenopalpus pulcher (Canestrini \& Fanzago, 1876)

Eotetranychus carpini (Oudemans, 1905)

Eotetranychus willamettei (McGregor, 1917)

Oligonychus vitis Zaher \& Shehata, 1965

Panonychus ulmi (Koch, 1836)

Tetranychus canadensis (McGregor, 1950)

Tetranychus mcdanieli McGregor, 1931

Tetranychus pacificus McGregor, 1919

Tetranychus schoenei McGregor, 1941

Tetranychus turkestani (Ugarov\& Nikolskii, 1937)

Tetranychus urticae Koch, 1836

\section{CULTURA}

maçã

maçã

uva

uva

maçã

maçã

maçã e uva

uva

uva

maçã e uva

maçã

maçã e uva

uva

maçã

maçã e uva

maçã e uva 
3.4.3. Avaliação da importância quarentenária de ácaros associados à maçã e/ou uva para o Brasil.

\subsubsection{Aculus schlechtendali (Nalepa, 1890) (Eriophyidae)}

- Sinônimos - Phyllocoptes schlechtendali, Vasates schlechtendali

- Nome vulgar - "apple rust mite"

- Distribuição geográfica - América do Norte (Canadá e EUAN), América do Sul (Chile), Europa (Alemanha, Áustria, Bélgica, Dinamarca, Holanda, Inglaterra, Itália, Noruega, Polônia e Suiça), Ásia (Japão) e Oceania (Austrália) (Bodingius, 1990; Easterbrook, 1979; Forsythe \& Rings, 1966; Funayama \& Takahashi, 1993; Gonzalez, 1981; Hohn \& Hopli, 1990; Kozlowski, 1980; Lienk et al., 1980; Matkowski \& Schadegg, 1988; Palm, 1985; Paradis et al., 1979; Rota \& Ciampolini, 1966-67; Russ et al., 1974; Soenen et al., 1977; Solhoy et al., 1991).

- Hospedeiros - O principal hospedeiro cultivado de A. schlechtendali é a maçã (Malus domestica), mas também é encontrado em pêra (Pyrus communis); os hospedeiros silvestres são: diversas espécies de Malus - M. aldenhamensis, M. baccata, M. brevipes, M. florentina, M. fusca, M. hartwigii, M. hupehensis, $M$. niedzwetzkyana, M. orthocarpa, $M$. platycarpa, $M$. sargenti, $M$. trilobata, $M$. zumi, $M$. floribunda e Pyrus faurei (Easterbrook, 1979).

- Características biológicas - O ciclo de vida de $A$. schlechtendali foi de 39, 16 e 10 dias a $10^{\circ} \mathrm{C}, 16^{\circ} \mathrm{C}$ e $22^{\circ} \mathrm{C}$, respectivamente (Easterbrook, 1979). Todos os limiares inferiores de temperatura foram abaixo de $7,5^{\circ} \mathrm{C}$ (Easterbrook, 1984b). Os adultos passam o inverno em diapausa sobre as plantas. A fecundidade das protoginas varia de 67 a 102 ovos, e das deutoginas, de 21 a 47 ovos, após a hibernação no sudeste da 
Inglaterra (Easterbrook, 1979). Nos EUAN foram observadas 4 ou 5 gerações por ano e, no Canadá, 3 gerações (Herbert, 1974; Oatman, 1973).

$\Rightarrow$ Potencial de importância econômica - Alto

- importância econômica e/ou social de seus hospedeiros no Brasil

O principal hospedeiro de $A$. schlechtendali cultivado no Brasil é a maçã, fruta de grande importância econômica (ítem 3.4.1) (Brasil, 1994).

\section{- danos e perdas causadas pelo ácaro}

Na Itália, infestações de $A$. schlechtendali causaram sérios danos a brotos, particularmente em plantas jovens, levando à inibição do crescimento, com consequências diretas sobre a forma de crescimento das árvores e precocidade da frutificação em cultivares do grupo Delicious, especialmente Golden e Stark (Rota \& Ciampolini, 196667; Strapazzon \& Monta, 1988).

Quando abundantes, estes ácaros também alimentam-se nos frutos, causando-lhes ferrugem na região próxima ao final do cálice (Lienk et al., 1980). Para a maioria das cultivares de maçã observa-se uma correlação entre o número de ácaros alimentando-se sobre os frutos ou a densidade populacional destes nos pomares e a quantidade de ferrugem na região final do cálice e superfície das maçãs (Ciampolini et al., 1976; Easterbrook \& Fuller, 1986; Lyne, $1981^{7}$ in Easterbrook, 1984b; Matkowski \& Bang Madsen, $1989^{8}$ in Solhoy et al., 1991). Entretanto, com outras variedades, como Aroma, não se observou esta relação (Solhoy et al., 1991).

Observou-se uma diminuição de $60 \%$ na atividade fotossintética nas folhas de macieiras que apresentavam sintomas de infestação (Solhoy et al., 1991). Easterbrook (1991) sugere que altos níveis populacionais de $A$. schlechtendali na primavera podem reduzir a produção.

\footnotetext{
${ }^{7}$ LYNE, P. M. In: BRITISH CROP PROTECTION CONFERENCE, PESTS AND DISEASES, Proceedings. 1981. p. 83-88.

${ }^{8}$ MATKOWSKI, A.; BANG MADSEN, H. Frugtavleren, v.5, p.161-164, 1989.
} 
O nível de dano estabelecido para $A$. schlechtendali em macieiras é variável. De acordo com Croft (1975), em Michigan, EUAN, populações acima de 200 ácaros/folha, alimendando-se por 10-14 dias, podem afetar negativamente a produção de frutos e o vigor das plantas. Um nível de dano próximo a este, de 200-300 ácaros/folha após a floração, foi sugerido por Hohn \& Hopli (1990) na Suiça. Diferentemente, populações de cerca de 300 ácaros/folha causaram aparentemente poucos danos à cultura em Washington, EUAN (Hoyt, 1969).

Os danos causados por infestações de $A$. schlechtendali variam bastante em função das variedades de macieiras cultivadas.

Easterbrook \& Fuller (1986) sugerem que as cultivares utilizadas nos EUAN são menos susceptíveis aos danos nos frutos que as do Reino Unido, onde grandes populações de ácaros não podem ser toleradas em períodos críticos. As cultivares consideradas susceptíveis por estes autores foram Crispin, Cox, Bramley e Golden Delicious.

Em Nova Scotia, Canadá, comparou-se a densidade populacional de A. schlechtendali em 10 diferentes cultivares de maçã (Red Delicious, McIntosh, Red Spy, Wagener, Cortland, Gravenstein, Spartan, Quinte, Early Mc Intosh e Golden Delicious), tendo Red Delicious se mostrado a mais susceptível (Herbert, 1974).

Na Polônia, as infestações mais elevadas de $A$. schlechtendali em 1989-90 foram observadas sobre as cultivares Jonagold, Elstar, Idared, Boiken, Gloster, McIntosh, Cortland e Mecaun (Badowska-Czubik \& Pala, 1993). No mesmo país, testes realizados por Kozlowski \& Kozlowska (1994), indicaram que as variedades de maçã mais susceptiveis à infestação por $A$. schlechtendali foram James Grieve e Starking. Menores populações foram encontradas sobre Golden Delicious e Spartan. As cultivares menos atacadas foram Cesarz Wilhelm e Beforest.

Em um surto ocorrido em 1989 na Holanda, as cultivares mais atacadas foram Elstar e Jonagold (Bodingius, 1990).

No Brasil, as cultivares mais utilizadas são Gala, Golden Delicious e Fuji. Em menor escala, são plantadas as cultivares Sanshu, Braeburn, Sansa e Jonagold (Freire et al., 1994). Dentre estas cultivares, de acordo com os trabalhos realizados em outros 
países, Golden Delicious é susceptível e, sobre Jonagold foram observadas sérias infestações (Badowska-Czubik \& Pala, 1993; Easterbrook \& Fuller, 1986). Isto indica que estas cultivares utilizadas no Brasil podem ser severamente atacadas pelo eriofí́deo.

Em determinadas situações, $A$. schlechtendali é considerado uma espécie benéfica, pois pode apresentar um importante papel no manejo integrado de pragas na cultura da maçã, sendo utilizado como alimento por fitoseídeos quando populações de outros ácaros-praga estão baixas. Entretanto, deve-se saber qual o nível populacional que pode ser tolerado sem danos às árvores, pois a taxa de desenvolvimento destes ácaros é tão rápida que, mesmo em hospedeiros com estado nutricional deficiente e na presença de ácaros predadores, eles podem alcançar níveis bem acima do dano econômico (Easterbrook, 1979). O papel benéfico da espécie foi relatado nos EUAN (Califórnia e Nova York), Chile e Japão (Funayama \& Takahashi, 1993; Glass, 1975; Gonzalez, 1981; University of California, 1991).

Não se dispõe de dados sobre perdas quantitativas causadas por A. schlechtendali. As referências em relação à importância econômica da espécie são diversas. A maioria dos autores consideram-na uma das pragas mais importantes da cultura, que causa severos danos econômicos (Angerilli \& Brochu, 1987; Croft, 1975; Easterbrook \& Palmer, 1996; Kozlowski, 1980; Laffi \& Giovanni, 1978; Paradis et al., 1979; Prokopy et al., 1980; Rota \& Ciampolini, 1966-67; Sterk, 1994); entretanto, outros consideram-na uma praga temporária ou secundária, causando prejuízos ocasionais (Bodingius, 1990; Forsythe \& Rings, 1966; Hagley et al., $1977^{9}$ in Li \& Harmsen, 1992; Russ et al., 1974; Soenen et al., 1977); ainda outros afirmam que a espécie não alcança níveis de praga (Hohn \& Hopli, 1990; Hudson, 1971), ou que é benéfica à cultura, como citado anteriormente.

As informações não concordantes quanto aos danos e perdas causadas por infestações de $A$. schlechtendali sugerem que estes dependem de muitos fatores. Possivelmente, as condições climáticas, a resistência de cultivares e a presença de inimigos naturais sejam os mais importantes.

\footnotetext{
${ }^{9}$ HAGLEY, E. A. C.; MONTEITH, L. G.; HERNE, D. H. C.; TROTTIER, R. Pest population buildup in apple orchards following omission of insecticide sprays. Proceedings of the Entomological Society of Ontario, v.108, p.7-11, 1977.
} 


\section{- medidas utilizadas para o controle da espécie}

De uma maneira geral, pesticidas são eficientes para o controle de A. schlechtendali.

Devido aos danos causados aos frutos, é necessário controlar os ácaros antes da floração (Easterbrook, 1984b). Os pesticidas que têm sido utilizados para o controle de A. schlechtendali são: pirimifós-metila, carbaril, amitraz, fungicidas sulforados, cihexatina, óxido de fenbutatina, fentrifanil, hexadecil ciclopropanocarboxilato, azociclotina, clofentezine, fenpiroximato, piridabem, dicofol, enxofre, bromopropilato, endosulfam, fenpropatrina, dicofol + tetradifom, propargite e mevinfós (Aveyard, 1988; Badowska-Czubik \& Pala, 1993; Bodingius, 1990; Bostanian et al., 1981; Ciampolini et al., 1976; Easterbrook, 1984a; Easterbrook, 1984b; Epenhuijsen, 1981; Funayama \& Takahashi, 1993; Pitre \& Bostanian, 1980; Schliesske, 1984).

Apesar da maioria dos trabalhos relatarem a eficiência de um grande número de pesticidas no controle de $A$. schlechtendali, tem sido relatado o desenvolvimento de resistência por populações da espécie a alguns produtos. Herbert \& Sanford (1969) relataram resistência de populações deste eriofídeo a organofosforados em Nova Scotia, Canadá. Vários ensaios mostraram que populações de $A$. schlechtendali da Bélgica e Holanda desenvolveram resistência a piretróides sintéticos, mesmo àqueles com boa atividade acaricida, carbamatos, hidrocarbonetos clorados e organofosforados (Sterk \& Highwood, $1992^{10}$ in Sterk, 1994). Estas citações indicam que, devido à intensa utilização de pesticidas para o controle de ácaros em macieiras, incluindo $A$. schlechtendali, pode-se ter problemas no controle químico da espécie.

Em alguns países o controle biológico é um componente fundamental no manejo de pragas de maçã. $\mathrm{Na}$ Holanda, o ácaro fitoseídeo Typhlodromus pyri Scheuten foi reintroduzido para o controle de $A$. schlechtendali e Panonychus ulmi (Koch) e, após 1 a 2 anos utilizando-se pesticidas seletivos, este predador se estabeleceu (Trapman \& Blommers, 1985). Em Oregon, EUAN, liberações inoculativas de duas espécies de fitoseídeos, Galendromus occidentalis (Nesbitt) e T. pyri controlaram eficientemente

${ }^{10}$ STERK, G.; HIGHWOOD, D. P. Implemention of IRAC anti-resistance guidelines with IPM programmes for Belgian apple and pear orchards. In: BRITISH CROP PROTECTION CONFERENCE, PESTS AND DISEASES, Brighton, 1992. Proceedings. 1992. p.517-526. 
A. schlechtendali. (Croft \& Mac Rae, 1992). Estes ácaros predadores, que vêm controlando eficientemente populações de $A$. schlechtendali em outros países, não ocorrem no Brasil. Caso este eriofídeo seja introduzido e se estabeleça como praga no Brasil, na ausência de seus inimigos naturais, provavelmente irá atingir niveis populacionais mais altos que nos países onde estes estão presentes.

- problemas para exportação de frutos em países onde $\boldsymbol{A}$. schlechtendali ocorre.

A exportação de frutos de maçã por alguns países tem sido impedida por níveis zero de tolerância a $A$. schlechtendali e ovos de $P$. ulmi, estabelecidos por vários países importadores, sendo necessária a realização de tratamentos para a eliminação destes ácaros dos frutos, antes da exportação (Lidster et al., 1981). Portanto, caso este eriofí́deo seja introduzido no Brasil, poderá ser necessária a realização de tratamentos específicos dos frutos antes de sua exportação para eliminação de formas viáveis dos ácaros.

Apesar das informações sobre a importância econômica de $A$. schlechtendali diferirem entre os países em que a espécie ocorre, considera-se alto o potencial da espécie em causar problemas de ordem econômica no Brasil, pelo fato de seu principal hospedeiro cultivado apresentar importância econômica no país, de serem relatadas perdas na produção devido às infestações pela espécie em alguns países, e de um dos cultivares mais utilizados no país - Golden Delicious - ser relatado como susceptível às infestações pela espécie. Além disso, os principais inimigos naturais de $A$. schlechtendali não são assinalados no Brasil e, certamente, isto favoreceria o aumento populacional da espécie no país. A necessidade de utilização de pesticidas para o controle da espécie pode levar a um aumento nos problemas ambientes e elevar o custo de produção da cultura. Ademais, existem referências relatando o desenvolvimento de resistência a pesticidas por populações da espécie. 


\section{$\Rightarrow$ Potencial de Introdução - Alto}

- possibilidades de infestação dos produtos importados nos países de origem

* presença e abundância da espécie nos países exportadores.

Entre os paises exportadores de frutos de maçã para o Brasil (Anexo B, Tabela 1) (Brasil, 1996), A. schlechtendali ocorre nos EUAN, Canadá, Chile, Holanda, Itália e Inglaterra.

A espécie é abundante nos EUAN, particularmente em Michigan, Massachusetts, Virginia, Oregon e Washington (Croft, 1975; Hudson, 1971; Parrela et al., 1981; Prokopy et al., 1980); no Canadá, em Ontario, British Columbia e Quebec (Angerilli \& Brochu, 1987; Li \& Harmsen, 1992; Paradis et al., 1979); na Inglaterra (Easterbrook, 1979; Easterbrook, 1984b); Itália (Ciampolini et al., 1976) e Holanda (Bodingius, 1990).

Além de frutos, $A$. schlechtendali também pode ser introduzido no Brasil através da importação de mudas de macieiras da Holanda, país onde a espécie é freqüentemente encontrada e onde foram relatados problemas de resistência a pesticidas (Sterk \& Highwood, $1992^{11}$ citado por Sterk, 1994).

* volume, frequência e época das importações

$\mathrm{O}$ volume das importações de frutos de maçã de países onde $A$. schlechtendali ocorre têm sido bastante grande, destacando-se as importações dos EUAN e Chile que têm sido, respectivamente, os segundo e terceiro principais exportadores de maçãs para o Brasil. A frequência das importações de maçãs destes países têm sido alta, tendo sido importados 49 lotes dos EUAN e 45 do Chile, respectivamente, no período considerado (Anexo B, Tabela 1) (Brasil, 1996).

Grandes quantidades de mudas de macieiras também têm sido importadas da Holanda, totalizando 336.835 unidades neste mesmo período (Brasil, 1996).

${ }^{11}$ STERK, G; HIGHWOOD, D. P. Implemention of IRAC anti-resistance guidelines with IPM programmes for Belgian apple and pear orchards. In: BRITISH CROP PROTECTION CONFERENCE, PESTS AND DISEASES, Brighton, 1992. Proceedings. 1992. p.517-526. 
Em Washington, EUAN, observaram-se dois picos populacionais de A. schlechtendali, sendo o mais alto em junho ou julho, quando as populações alcançaram níveis de 2000 ácaros/folha, e um segundo pico, no final de agosto ou setembro (Hoyt, $1969^{12}$ citado por Easterbrook, 1979). As importações de maçãs dos EUAN têm sido realizadas durante praticamente todo o ano, exceto em maio e junho (Anexo C, Tabela 1) (Brasil, 1996). Portanto, são grandes as possibilidades de importação de maçãs infestadas dos EUAN.

No sudeste da Inglaterra observou-se que as populações de $A$. schlechtendali alcançam um pico populacional em agosto (Easterbrook, 1979). Entretanto, as importações de frutos de maçã deste país têm sido realizadas em abril (Anexo C, Tabela 1) (Brasil, 1996). Desta forma, o risco de infestação de produtos importados existe, mas seria maior se o maior número de importações estivessem sendo realizadas entre os meses de junho e setembro.

Não se dispõe de informações sobre a fenologia de $A$. schlechtendali nos demais países exportadores de maçãs para avaliar se as importações de maçãs têm sido realizadas em épocas de alto risco de infestação.

Considerando os parâmetros acima, são grandes as possibilidades de infestação de maçãs ou mudas de macieiras por $A$. schlechtendali nos países exportadores destes produtos para o Brasil, especialmente no caso de maçãs dos EUAN.

\section{- possibilidades de sobrevivência da espécie às condições de transporte dos materiais.}

As temperaturas recomendadas para o transporte de maçãs são baixas e a umidade relativa que deve ser mantida nos containers é bastante elevada (Anexo E) (Brasil, 1994). As deutoginas de A. schlechtendali passam o inverno em dormência (Croft, 1975; Easterbrook, 1979), sobrevivendo, desta forma, às baixas temperaturas do inverno. Em observações realizadas na Polônia, a sobrevivência no inverno variou de 50 a 76\% (Kozlowski \& Boczek, 1987). Portanto, é possível que deutoginas que fossem

\footnotetext{
${ }^{12}$ HOYT, S. C. Population studies of five mite species on apple in Washington. In: INTERNATIONAL CONGRESS OF ACAROLOGY, 2., 1967. Proceedings. 1969. p. 117-133.
} 
migrar para os locais de hibernação associadas a frutos de maçãs sobrevivam às condições de transporte dos mesmos.

São grandes as possibilidades de sobrevivência de $A$. schlechtendali porventura associados a mudas de macieiras, às condições de transporte das mesmas.

\section{- possibilidades de detecção dos ácaros na ocasião da chegada de produtos infestados no Brasil.}

\section{* localização na planta hospedeira}

A deteç̧ão de $A$. schlechtendali em mudas ou frutos é bastante dificil, pois estes ácaros podem encontrar-se em locais protegidos nestes produtos. As deutoginas de A. schlechtendali passam o inverno sob as escamas das gemas ou nas fissuras da casca (Croft, 1975; Easterbrook, 1979; Herbert, 1974). Na primavera, as deutoginas se tornam ativas, movimentando-se dos sítios de hibernação em direção às lâminas folhares, flores ou frutos em início de formação, principalmente na região do final do cálice (Easterbrook, 1984b).

\section{* dimensões/ coloração da espécie}

Estes ácaros são de dificil detecção devido às suas reduzidas dimensões e à coloração discreta da maioria dos estágios de desenvolvimento. A. schlechtendali, como os demais eriofí́deos, são ácaros extremamente pequenos. Os ovos medem 47-53 $\mu \mathrm{m}$ de diâmetro; os machos medem 142-151 um e as fềmeas de 166 a $181 \mu \mathrm{m}$ de comprimento. Inicialmente, os ovos são claros, tornando-se translúcidos posteriormente. As protoninfas são inicialmente brancas. Gradualmente a cutícula torna-se brilhante e posteriormente varia de branca a marrom-alaranjado pálido. As deutoninfas são marrom-alaranjadas pálidas. Os adultos apresentam coloração marrom-alaranjada, escurecendo com a idade (Easterbrook, 1979). 
* apresentação de sintomas em plantas/produtos infestados

As folhas infestadas por $A$. schlechtendali podem apresentar a superficie inferior amarelo-amarronzada ou enrolamento das bordas para cima. A alimentação de mais de 500 ácaros/folha por 3-4 semanas pode causar manchas branco-prateadas na superficie superior das folhas. Quando abundantes, os ácaros alimentam-se nos frutos, causandolhes ferrugem, principalmente na região próxima ao final do cálice, mas também na superficie das maçãs (Easterbrook \& Fuller, 1986; Lienk et al., 1980). Na Itália, infestações por estes ácaros causou conspícua deformação folhar em brotações novas (Rota \& Ciampolini, 1966-67).

Portanto, a observação de sintomas de infestação em frutos ou mudas pode auxiliar a deteç̧ão de $A$. schlechtendali. Entretanto, a ausência de sintomas não deve ser considerada como ausência de infestação. Na Polônia, os primeiros sinais visíveis de alimentação pelos ácaros somente foram observados a uma densidade de 10 ácaros $/ \mathrm{cm}^{2}$ (Kozlowski, 1980).

Considerando os parâmetros acima, são poucas as possibilidades de detecção de A. schlechtendali na ocasião da chegada de produtos infestados no Brasil.

\section{$\Rightarrow$ Potencial de estabelecimento - Alto}

\section{- disponibilidade de hospedeiros}

Os hospedeiros de $A$. schlechtendali que ocorrem no Brasil são maçã e pêra cultivadas. A maçã é cultivada em cerca de 27.318 ha, tendo como principais estados produtores Santa Catarina, Rio Grande do Sul, Paraná e São Paulo, encontrando-se também em menor escala em Minas Gerais e Espírito Santo. A pêra é cultivada em cerca de 2.303 ha, principalmente no Rio Grande do Sul, Minas Gerais, São Paulo e Paraná, mas também em Santa Catarina e Espírito Santo (Anuário Estatístico do Brasil, 1997).

A maior parte das importações de frutos de maçã de países onde A. schlechtendali ocorre têm sido destinadas aos estados onde são cultivadas as áreas mais extensas de maçã e pêra. As maçãs importadas dos EUAN têm sido destinadas 
principalmente a São Paulo (61,69\%), Santa Catarina (19,03\%) e Paraná $(9,25 \%)$. A maior parte da maçãs importadas do Chile têm sido destinadas a São Paulo $(78,6 \%)$ e Paraná $(11,5 \%)$. Todas as importações de maçãs do Canadá têm sido destinadas a São Paulo e as da Inglaterra, ao Rio Grande do Sul. A quase totalidade das maçãs importadas da Holanda $(99,9 \%)$ foi destinada a Santa Catarina e da Itália $(99,9 \%)$ ao Rio Grande do Sul (Anexo D, Tabelas 1) (Brasil, 1996).

Todas as importações de mudas de macieiras importadas da Holanda têm sido destinadas ao Rio Grande do Sul, que é o principal produtor de maçãs e pêras no Brasil (Anuário Estatístico do Brasil, 1997; Brasil, 1996).

Portanto, há grande disponibilidade de hospedeiros para $A$. schlechtendali no Brasil, especialmente nos estados para onde produtos potencialmente infestados têm sido destinados.

\section{- adequação das condições climáticas brasileiras para a sobrevivência, desenvolvimento e reprodução da espécie}

São poucas as informações disponíveis sobre as condições climáticas favoráveis e desfavoráveis ao desenvolvimento de $A$. schlechtendali.

A $22^{\circ} \mathrm{C}$, o ciclo de vida da espécie é mais curto e a fecundidade das fêmeas é maior, em comparação às temperaturas de 10 a $16^{\circ} \mathrm{C}$ (Easterbrook, 1979). O limiar inferior de temperaturas para ovos de $A$. schlechtendali é de $7,2^{\circ} \mathrm{C}$ (Easterbrook, 1984b). Portanto, nas regiões brasileiras produtoras de maçã, onde as temperaturas médias são próximas ou superiores a $20^{\circ} \mathrm{C}$ e as temperaturas mínimas médias são superiores a $7,2^{\circ} \mathrm{C}$, exceto durante o inverno, as condições climáticas propiciam fecundidade mais elevada e ciclo de vida mais curto a A. schlechtendali (Brasil, 1992).

Em Washington, EUAN, observou-se um declínio na população de A. schlechtendali no meio do verão, o que foi correlacionado com uma ocorrência prolongada de temperaturas acima de $35^{\circ} \mathrm{C}$ e umidade relativa próxima a $20 \%$ (Hoyt, $1969^{13}$ citado por Easterbrook, 1979). Nas regiões brasileiras produtoras de maçã as

${ }^{13}$ HOYT, S. C. Population studies of five mite species on apple in Washington. In: INTERNATIONAL CONGRESS OF ACAROLOGY, 2., 1967. Proceedings. 1969. p. 117-133. 
temperaturas são elevadas durante o verão, chegando a $40^{\circ} \mathrm{C}$ em alguns municípios, como Rio Grande (Rio Grande do Sul), entretanto, a umidade relativa normalmente é superior a $70 \%$ (Brasil, 1992).

Portanto, consideram-se as condições climáticas nas regiões brasileiras produtoras de maçã adequadas ao desenvolvimento de $A$. schlechtendali.

\section{- uso proposto}

Os ácaros que, porventura, estejam infestando mudas de macieiras apresentam um alto potencial de estabelecimento.

\section{- potencial reprodutivo}

O potencial reprodutivo de $A$. schlechtendali é elevado. A fecundidade desta espécie é alta, sendo que o número de ovos chega a 102 por fềmea (Easterbrook, 1979).

Nos EUAN, foram observadas 4 a 5 gerações por ano (Oatman, 1973). Provavelmente, no Brasil, devido à disponibilidade de condições climáticas favoráveis ao desenvolvimento por um período de tempo mais longo que neste país, o número de gerações por ano da espécie seria mais elevado.

O potencial de estabelecimento de $A$. schlechtendali é considerado alto devido à grande disponibilidade de hospedeiros nos estados para onde os produtos potencialmente infestados têm sido destinados, à prática de importação de material para propagação e ao alto potencial reprodutivo da espécie. Também, de acordo com uma análise preliminar, consideram-se as condiçoes climáticas nos estados produtores de maçã, principal hospedeiro deste ácaro, adequadas ao seu desenvolvimento. 


\subsubsection{Amphitetranychus viennensis (Zacher, 1920) (Tetranychidae)}

- Sinônimos - Tetranychus (Epitetranychus) viennensis Zacher, 1920; Tetranychus viennensis Zacher, 1920; Tetranychus crataegi Hirst, 1920; Apotetranychus longipenis Ugarov \& Nikolskii, 1937; Apotetranychus virginis Ugarov, 1937 (Flechtmann ${ }^{14}$ )

- Nomes vulgares - "hawthorn mite"; "buckthorn red spider mite"; "Viennese spider mite"

Distribuição geográfica - Europa (Alemanha, Austria, Azerbaijão, Bélgica, Bulgária, Eslováquia, Espanha, França, Geórgia, Grécia, Holanda, Hungria, Itália, Lituânia, Polônia, Portugal, Reino Unido, Romênia, Suécia, Suiça, Ucrânia), Ásia (China, Coréia, Irã, Japão, Líbano, Paquistão, Rússia, Taiwan, Turquia) (Chepumaya \& Myalova, 1981; Flechtmann ${ }^{14}$, Lobzhanidze, 1980; Soenen et al., 1977; Zil Bermints, 1979).

Hospedeiros - Apocynaceae (Plumeria sp.), Betulaceae (Corylus avellana), Fagaceae (Quercus sp.), Moraceae (Ficus carica), Rosaceae (Amelanchier canadensis, Chaenomeles sp., Crataegus azarolus, C. grandiflora, C. monogyna, C. sp., Cydonia oblonga, Fragaria sp., Malus domestica, M. floribunda, M. hissarica, M. sieboldii, Mespilus sp., Prunus acida, P. armeniaca, P. avium, P. cerasus, P. domestica, $P$. divaricata, $P$. dulcis, $P$. insititia, $P$. persica, $P$. sagdiana, $P$. serrulata, $P$. spinosa, P. taiwanina, Pyrus communis, P. pollveria, P. pyrifolia, P. sp., Rubus idaeus, R. plicatus, Sorbus intermedia, S. sp.), Tiliaceae (Tilia sp.) (Flechtmann ${ }^{14}$ ).

- Características biológicas - O tempo de desenvolvimento varia entre machos e fêmeas, entre diferentes localidades e ao decorrer do ano. Na Alemanha, uma geração leva de 20 a 30 dias para fêmeas e de 8 a 16 dias para machos; na Turquia varia de 12 a 25 dias para fềmeas; no Irã varia de 84 a 106 dias e na China o tempo médio de uma geração foi de 24,5 dias (Jeppson et al., 1975; Liu \& He, 1991; Sepasgozarian \& Schruft,

${ }^{14}$ FLECHTMANN, C. H. W. (Pesquisador CNPq, Depto. Zoologia, ESALQ, Universidade de São Paulo, Piracicaba, SP). Comunicação pessoal, 1997. 
1975). Em laboratório, uma geração leva de 12 a 14,5 dias a $22-25^{\circ} \mathrm{C}$ e 43,8 dias a $15^{\circ} \mathrm{C}$ (Gotoh, 1987; Jeppson et al., 1975). O limiar inferior de temperatura é de $11,42^{\circ} \mathrm{C}$ (Gotoh, 1987). O número de gerações por ano variou de 4, no Japão a 10 , na Turquia (Gotoh, 1984 e 1987, Jeppson et al., 1975). Em laboratório a $22-25^{\circ} \mathrm{C}$, as fềmeas põem de 70 a 82 ovos e, no Irã, de 36 a 154 ovos durante todo o ciclo de vida (Jeppson et al., 1975; Sepasgozarian \& Schruft, 1975).

$\Rightarrow$ Potencial de importância econômica - Alto

- importância econômica e/ou social de seus hospedeiros no Brasil

Os hospedeiros de $A$. viennensis cultivados no Brasil são: maçã, morango, pêra, pêssego, marmelo, figo e ameixa. A cultura à qual $A$. viennensis vem causando maiores problemas em outros países é a da maçã, fruta de grande importância econômica para o Brasil (ítem 3.4.1) (Anuário Estatístico do Brasil, 1997; Brasil, 1994).

\section{- danos e perdas causadas devido às infestações pela espécie}

$\mathrm{Na}$ China, macieiras apresentaram alterações em todos os índices fisiológicos devido às infestações por $A$. viennensis e Panonychus ulmi (Koch). Não foram observados efeitos significantes das infestações na qualidade dos frutos, mas houve uma redução no tamanho destes no ano da infestação e no número de flores e frutos no ano seguinte à infestação (Cai et al., 1992).

Foram relatadas perdas bastante sérias na produção de maçãs devido às infestações por $A$. viennensis. Em Crimea, Ucrânia (CIS), populações de 100 ou mais ácaros por folha resultaram em perdas de produção de 40-65\% (Bulgak, 1979). Em 1988, quando as perdas de produção na China foram causadas principalmente por A. viennensis, variaram de 2,36 a $13,48 \% \mathrm{e}$, no ano seguinte às infestações, foram superiores a 69,4\% (Cai et al., 1992).

A. viennensis é praga de cereja na Ucrânia (Skiba \& Parii, 1989); de maçã na Bulgária, Turquia e China (Bulut et al., 1992a; Chak"rov, 1970; Geoffrion, 1987; Huang \& Hu, 1987); de pêras na China (Geoffrion, 1987); de pêssegos na Turquia (Tuzum \& 
Gurses, 1972) e de frutíferas de folhas decíduas no Japão (Gotoh, 1984). É considerada uma das pragas mais importantes de pêras e maçãs na China (Geoffrion, 1987; Huang \& Hu, 1987) e de cerejas na Ucrânia (Skiba \& Parii, 1989).

- medidas utilizadas para o controle da espécie

Os acaricidas que vêm sendo utilizados nos últimos anos para o controle da espécie são cihexatina, dicofol, amitraz, propargite, azociclotina, dinobutom, benzoximato e óxido de fenbutatina (Bulut et al., 1992a; Esaulov \& Roslavtseva, 1983; Loladse, 1989; Lopadze \& Partsvaniya, 1984; Sun et al., 1992). Alguns inseticidas utilizados para o controle de Cydia pomonella $\mathrm{L}$. em macieiras, como lambda-cialotrina e fenpropatrina, controlaram os ácaros e fenvalerato manteve as populações abaixo do nível de dano econômico (Bulut \& Zeki; 1992).

São vários os relatos de desenvolvimento de resistência a pesticidas em populações de $A$. viennensis, tornando inefetivo o controle químico. Na China, observouse resistência da espécie a propargite e monocrotofós, alta resistência a carbofós e quinalfós e um aumento de 5 a 99 vezes na resistência a dicofol, clordimeform, paratiom e dimetoato no período de 1984 a 1988 (Cao et al., 1990; Shen \& Zhong, 1994). Em CIS, a aplicação regular de dimetoato, fosalone e compostos relacionados em pomares de maçã resultou no desenvolvimento de resistência por populações da espécie (Galetenko, 1976).

$\mathrm{O}$ controle biológico de $A$. viennensis mostrou-se eficiente em culturas onde se utiliza o manejo integrado de pragas. Os predadores de $A$. viennensis mais efetivos são: o coccinelídeo Stethorus punctillum (Weise), o neuróptero Conventzia sp., o mirídeo Malacocoris chlorizans Panz. e os ácaros fitoseídeos Amblydromella sternlichti (Swirski \& Amitai), Euseius finlandicus (Oudemans) e Kampimodromus aberrans (Oudemans) (Loladse, 1989; Orman \& Bakanligi, 1989; Yigit \& Uygun, 1982). Na China, linhagens do fitoseídeo Galendromus occidentalis (Nesbitt) resistentes a organofosforados foram introduzidos dos EUAN e Austrália em pomares de maçã, estabelecendo-se em várias localidades e levando a uma redução de 3 a 4 aplicações de acaricidas por ano (Zhang et al., 1987 e 1988). 
Os predadores relatados como mais efetivos para o controle de $A$. viennensis não ocorrem no Brasil. Portanto, caso a praga seja introduzida no país, poderá não sofrerá a ação de inimigos naturais e então alcançar níveis populacionais mais altos que nos países onde estes ocorrem.

\section{- status quarentenário}

A. viennensis é uma espécie de importância quarentenária para a América do Norte (Kahan, 1989). Portanto, a introdução desta espécie no país levará a restrições nas importações de maçãs brasileiras por paises norte-americanos, que, atualmente, representam o segundo principal mercado importador destes frutos do Brasil, após a Comunidade Européia (Brasil, 1994).

O potencial de $A$. viennensis em causar problemas de ordem econômica no Brasil é considerado elevado, pois esta espécie vem causando sérias perdas de produção em outros países, têm sido necessária a aplicação de pesticidas para o controle e são relatados problemas de resistência a pesticidas por populações da praga; seus principais inimigos naturais não ocorrem no país e sua introdução levará a perdas de mercado de exportação ou a restrições nas exportações de frutos brasileiros.

\section{$\Rightarrow$ Potencial de Introdução - Médio}

- possibilidades de infestação dos produtos importados nos países de origem

* presença e abundância da espécie nos países exportadores.

Considerando as referências sobre hospedeiro $\mathrm{x}$ país e os dados sobre as importações, as principais vias de ingresso de $A$. viennensis no Brasil são pêras da China e maçãs da Hungria (Anexo B, Tabelas 1 e 2 ).

Na China, A. viennensis é uma espécie bastante abundante em pomares de macieiras e pereiras, sendo considerado uma das principais pragas destas culturas 
(Geoffrion, 1987). Não se dispõe de informações sobre a abundância de $A$. viennensis na Hungria.

\section{* volume, frequência e época das importações}

$O$ volume das importações de pêras da China e de maçãs da Hungria não tem sido grande quando comparado ao de outros países, sendo a China o $7^{\circ}$ exportador de pêras para o Brasil e a Hungria o $8^{\circ}$ exportador de maçãs. A frequência das importações também tem sido baixa, pois no período de janeiro de 1992 a agosto de 1996 foram realizadas 4 importações de maçãs da Hungria e apenas 1 de pêras da China (Anexo B, Tabelas 1 e 2) (Brasil, 1996).

Não se dispõe de informações sobre a fenologia de $A$. viennensis na China e Hungria para avaliar se as importações de frutos têm sido realizadas em épocas de alto ou baixo risco de infestação.

Há possibilidades de infestação dos produtos importados nos países de origem por A. viennensis, entretanto, devido às poucas vias de ingresso identificadas, aos pequenos volumes e às baixas freqüências das importações de produtos potencialmente infestados, consideram-se poucas estas possibilidades.

- possibilidades de sobrevivência da espécie às condições de transporte dos materiais.

Durante o inverno as fêmeas adultas de $A$. viennensis hibernam em locais protegidos nas plantas ou em suas proximidades. A sobrevivência às baixas temperaturas de inverno é elevada, pois $75 \%$ da população hibernante sobrevive até à primavera (Chepumaya \& Myalova, 1981; Soenen, 1977).

Há possibilidades de que frutos colhidos estejam infestados por fềmeas de A. viennensis que iriam migrar para sítios de hibernação. Estas fềmeas apresentam alta resistência a baixas temperaturas e provavelmente poderão sobreviver às condições de resfriamento em que pêras e maçãs são submetidas durante o transporte (Anexo E) (Brasil, 1994). 
Portanto, considera-se alta a possibilidade de sobrevivência dos ácaros às condições de tranporte dos produtos potencialmente infestados.

\section{- intercepção de $A$. viennensis em material vegetal importado}

Ácaros da espécie foram interceptados pelo "Yokohama Plant Protection Station", no Japão, em maçãs provenientes da China (Masaki, 1991). Isto indica a possibilidade de veiculação destes ácaros através de frutos e de sobrevivência dos mesmos às condições de transporte do material

- possibilidades de detecção dos ácaros na ocasião da chegada de produtos infestados no Brasil.

\section{* localização na planta hospedeira/produto}

Durante o inverno, as formas em diapausa de $A$. viennensis encontram-se em locais protegidos nas plantas ou em suas proximidades (Jeppson et al., 1975; Soenen, 1977). Estes ácaros podem ser encontrados em frutos (Masaki, 1991); não foram encontradas informações se estes se concentram na região do final do cálice ou se dispersam na superficie dos mesmos.

\section{* coloração da espécie}

Como as outras espécies de ácaros são organismos bastante pequenos. De uma maneira geral, todas as formas apresentam coloração viva. As fềmeas de verão são violeta-azuladas ou vermelhas-carmim com segmentos esbranquiçados. $\mathrm{O}$ macho é amarelo-areia, mas podem ser vistas manchas negro-esverdeadas no tegumento. As fềmeas hibernantes são vermelhas, brilhantes, com as extremidades amarelas ou areia (Jeppson et al., 1975).

Devido às pequenas dimensões da espécie, considera-se dificil sua deteç̧ão, especialmente a de ovos. A coloração viva da espécie pode facilitar sua visualização, exceto quando em substrato de coloração semelhante, como em frutos de maçã vermelhos. 
* apresentação de sintomas em plantas/produtos infestados

Não se dispõe de informações sobre apresentação de sintomas devido às infestações destes ácaros em frutos.

Como várias outras espécies de Tetranychidae, A. viennensis tece teia (Soenen, 1977), de modo que a presença desta nos frutos pode sinalizar a infestação.

Consideram-se baixas as possibilidades de detecção de $A$. viennensis na ocasião de sua introdução no país, apesar de algumas características da espécie poderem facilitar sua visualização (coloração, produção de teia), devido à carência de técnicos adequadamente treinados para a deteç̧ão de ácaros.

O potencial de introdução de introdução de $A$. viennensis no Brasil é considerado médio devido às poucas vias de ingresso identificadas e à baixa frequêencia das importações, apesar de haver fortes indicações das possibilidades de sobrevivência dos ácaros às condições de transporte dos frutos potencialmente infestados e consider-se baixa a possibilidade de detecção dos ácaros em produtos infestados ao serem introduzidos no país.

\section{$\Rightarrow$ Potencial de estabelecimento - Médio}

\section{- disponibilidade de hospedeiros}

Diversos hospedeiros de $A$. viennensis são encontrados no Brasil - carvalho, figo, marmelo, morango, maçã, pêra, ameixa, pêssego e framboesa. Os hospedeiros cultivados em maiores extensões são maçã, em 27.318 ha; pêssego, em 20.188 ha; pêra, em 2.303 ha; figo, em 2.191 ha e marmelo, em 1.363 ha (Anuário Estatístico do Brasil, 1997).

Como pode-se observar na Tabela 1 (Anexo D), a maior parte das maçãs importadas da Hungria no período de janeiro de 1992 a agosto de 1996 foram destinadas a Pernambuco, mas quantias consideráveis também foram destinadas à Bahia e São Paulo (Brasil, 1996). Em Pernambuco, não se encontram hospedeiros conhecidos de A. viennensis, entretanto na Bahia, apesar de que em áreas reduzidas, cultiva-se o 
marmelo. Em São Paulo, são diversos os hospedeiros da espécie cultivados, encontrandose extensas áreas de pêssego, maçã, figo e pêra (Anuário Estatístico do Brasil, 1997), além de áreas de cultivos de morangos e pomares de ameixa.

As pêras importadas da China foram destinadas ao Paraná, tendo sido introduzidas através de Santa Catarina (Anexo D, Tabela 2 ) (Brasil, 1996). Nestes dois estados encontram-se cultivos de maçã, pêra, pêssego e figo, sendo que Santa Catarina é o estado que apresenta a área mais extensa de cultivos de maçã (13.511 ha) (Anuário Estatístico do Brasil, 1997).

Portanto, há grande disponibilidade de hospedeiros para $A$. viennensis na maioria dos estados para onde têm sido destinados os frutos potencialmente infestados pela espécie.

\section{* adaptabilidade a novas plantas hospedeiras}

Em estudos de laboratório para verificar o tempo necessário para A. viennensis se adaptar a novas plantas hospedeiras e a possibilidade de infestar outras plantas, verificou-se que populações da espécie adaptaram-se em 2 ou 3 gerações, quando transferidas de Crataegus para maçã, pêra ou ameixa. Sua adaptabilidade foi bastante rápida quando comparada à de $T$. urticae, que tem levado mais de 10 gerações para se adaptar a uma nova planta hospedeira (Skorupska \& Boczek, 1985). Esta característica favorece o estabelecimento da espécie em novas áreas, quando não houver disponibilidade do hospedeiro ao qual os ácaros encontravam-se associados.

- adequação das condições climáticas brasileiras para a sobrevivência, desenvolvimento e reprodução da espécie

Baixas temperaturas e altas umidades são desfavoráveis ao aumento populacional de $A$. viennensis, sendo que a espécie é uma praga séria somente em regiões mais secas ou em anos secos (Chepumaya \& Myalova, 1981; Jeppson et al., 1975). 
No Brasil, as principais áreas de produção de fruteiras de clima temperado encontram-se em regiões húmidas, em que a umidade relativa normalmente é próxima ou superior a $70 \%$ (Brasil, 1992).

Portanto, em uma análise preliminar, pode-se dizer que as condições climáticas brasileiras não são favoráveis ao desenvolvimento de $A$. viennensis. Entretanto, deve-se proceder uma análise mais detalhada do parâmetro, a partir de dados climáticos mais precisos das regiões onde a espécie ocorre, comparando-as com as do Brasil.

\section{- potencial reprodutivo}

O potencial reprodutivo de $A$. viennensis é bastante elevado. As fềmeas apresentam alta fecundidade, variando de 70 a 82 ovos a $22-25^{\circ} \mathrm{C}$ e podendo chegar a 154 ovos, como observado no Irã (Jeppson et al., 1975; Sepasgozarian \& Schruft, 1975). Apresentam também grande número de gerações por ano, que chega a 10 na Turquia (Jeppson et al., 1975).

Apesar da disponibilidade de hospedeiros no Brasil, da fácil adaptabilidade a novos hospedeiros e do alto potencial reprodutivo de $A$. viennensis, há indicações de que as condições climáticas brasileiras nas regiões onde concentra-se as culturas de seus principais hospedeiros não são favoráveis ao seu desenvolvimento. Portanto, considera-se médio seu potencial de estabelecimento no país.

A. viennensis atualmente não é uma espécie de grande importância quarentenária para o Brasil, apesar de seu elevado potencial de importância econômica, pois, as vias de ingresso identificadas foram poucas e, em uma análise preliminar, as condições climáticas brasileiras das regiões onde seus principais hospedeiros são cultivados, não são favoráveis ao desenvolvimento da espécie. Entretanto, caso sejam identifcadas novas vias de ingresso da praga no país ou seja intensificado o comércio de maçãs e pêras com Hungria e China, respectivamente, deve-se proceder uma comparação mais detalhada entre as condições climáticas das regiões onde a espécie ocorre e as do Brasil. Novas vias de ingresso da praga no país podem surgir devido ao início da comercialização de produtos 
potencialmente infestados com outros países ou a novas informações sobre hospedeiro $\mathrm{x}$ distribuição da espécie.

\subsubsection{Brevipalpus chilensis Baker, 1949 (Tenuipalpidae)}

- Nomes vulgares - "falsa arañita de la vid"; "Chilean false red mite"

- Distribuição geográfica - América do Sul (Chile) (González, 1983a; Jeppson et al., 1975)

- Hospedeiros - Actinidiaceae (Actinidia chinensis), Annonacea (Annona cherimola); Apocynaceae (Vinca sp.), Bignoniaceae (Catalpa speciosa), Caprifoliaceae (Viburnum sp.), Convolvulaceae (Convolvulus arvensis), Compositae (Chrysanthemum sp.), Geraniaceae (Pelargonium), Grossulariaceae (Ribes georgiamus), Moraceae (Ficus carica), Oleaceae (Ligustrum sinensis) Passifloraceae (Passiflora edulis), Rosaceae (Cydonia oblonga, Malus domestica), Rutaceae (Citrus sp.), Scrophulariaceae (Antirrhinium), Solanaceae (Cestrum parqui), Vitaceae (Ampelopsis sp., Vitis sp.) (Aguilera, 1987; Gonzalez, 1983a e 1986; Vera, 1991).

- Características biológicas - $\mathrm{O}$ tempo médio de desenvolvimento requerido para completar uma geração é de 25,3 dias, variando de 18 a 59 dias. Ocorrem de 3 a 6 gerações por ano, dependendo do clima (Jeppson et al., 1975).

$\Rightarrow$ Potencial de importância econômica - Alto

- importância econômica e/ou social de seus hospedeiros no Brasil

O principal hospedeiro de $B$. chilensis é a uva, fruta de grande importância econômica para o Brasil (ítem 3.4.1) (Anuário Estatístico do Brasil, 1997; Brasil, 1994). 
B. chilensis também é comumente encontrado em marmeleiros e limoeiros, mas não são relatados danos nestes hospedeiros (Gonzalez, 1983a).

\section{- danos e perdas causadas devido às infestações pela espécie}

A alimentação de $B$. chilensis leva à queda das folhas e à redução no tamanho das novas brotações, encurtamento dos internódios, diminuição da produção e diminuição da graduação alcoólica do mosto resultante. Os danos mais sérios resultam dos ataques a ramos jovens na primavera (Jeppson et al., 1975).

Em algumas regiões do Chile foram observadas perdas de até $30 \%$ da produção de videiras devido às infestações por $B$. chilensis (Gonzalez, 1983a). Este ácaro é considerado uma das pragas mais nocivas à videiras no Chile (Gonzalez, 1983ab; Jeppson et al., 1975). Também causa danos locais em plantações de kiwi (Gonzalez, 1986).

\section{- medidas utilizadas para o controle da espécie}

Para o controle de $B$. chilensis têm-se utilizado basicamente o controle químico. São poucos os trabalhos científicos relacionados ao controle biológico desta espécie.

De acordo com Gonzalez (1983a), os acaricidas binapacril, dicofol, clorobenzilato, propargite e compostos estanhados exercem um excelente controle sobre $B$. chilensis. Em avaliações visando ao controle de $B$. chilensis em videiras observou-se que o óleo mineral apresentou um grau regular de controle sobre a espécie, superado por dicofol, na dose máxima recomendada (Curkovic et al., 1994). O mesmo foi observado por Montano (1995), pois aplicações de óleo mineral em concentrações de 2 e $3 \%$ controlaram eficientemente $B$. chilensis e tiveram efeito similar ao de dicofol.

Alguns predadores têm sido observados associados a $B$. chilensis. Em videiras, um considerável grau de controle da espécie foi observado com o ácaro fitoseídeo Neoseiulus californicus (= chilenensis) (McGregor) (Gonzalez, 1983a). Em cultura de "chirimoyo" em Tarapaca e Coquimbo, Chile, foi relatada a ocorrência do coccinelídeo Stethorus histrio Chazeau predando B. chilensis (Aguilera, 1987). 
O ácaro fitoseídeo $N$. californicus (= chilenensis) é assinalado no Brasil em Phaseolus vulgaris em São Paulo e em moranguinho no Rio Grande do Sul ${ }^{15}$ (Denmark \& Muma, 1973).

\section{- status quarentenário}

B. chilensis é considerado uma praga de importância quarentenária para videiras, outras frutíferas, plantas ornamentais e árvores (Holdeman, $1986^{16}$ in Kahan, 1989). O Departamento de Agricultura dos EUAN mantém um rigoroso controle para evitar a introdução desta espécie, exigindo tratamentos das frutas frescas provenientes do Chile (Gonzalez, 1983a).

Portanto, a introdução de $B$. chilensis no Brasil pode levar a restrições nas exportações de frutos brasileiros.

\section{- tratamentos quarentenários}

Ácaros desta espécie podem ser encontrados em frutos colhidos, sendo necessária a realização de tratamentos para sua eliminação, especialmente em frutos para exportação destinados a países onde $B$. chilensis é mantido sob quarentena.

Tratamentos com brometo de metila, a doses de 24 e $32 \mathrm{~g} / \mathrm{m} 3$, por 2 horas, causam 100\% de mortalidade de estágios móveis de B. chilensis (Gonzalez, 1983a).

Uma série de trabalhos vêm sendo realizados no Chile para verificar o efeito de diferentes produtos e condições de armazenamento de frutos de maracujá e "chirimoyo" para a eliminação de B. chilensis (Benavides, 1991; Ferrari, 1991; Thompson, 1990; Vera; 1991).

O potencial de importância econômica de $B$. chilensis é considerado alto principalmente devido à importância econômica de seu principal hospedeiro no Brasil- a

\footnotetext{
${ }^{15}$ MORAES, G. J. de (Pesquisador CNPq, Dept. Zoologia - Escola Superior de Agricultura "Luiz de Queiroz" - Piracicaba - SP - Brasil). Comunicação pessoal, 1996.

${ }^{16}$ HOLDEMAN, Q. (Ed.) Plant pests of phytosanitary significance to importing countries and states. 5.ed. Sacramento: California Department of Food and Agriculture, 1986.
} 
uva -, às elevadas perdas causadas pelas infestações nesta cultura no Chile e ao seu status quarentenário.

$\Rightarrow$ Potencial de Introdução - Alto

- possibilidades de infestação dos produtos importados nos países de origem

\section{* presença e abundância da espécie nos países exportadores.}

$B$. chilensis é comumente encontrado no Chile, importante país exportador de frutas frescas para o Brasil. Considerando os hospedeiros de $B$. chilensis e os dados sobre importações brasileiras, os frutos importados do Chile que podem estar infestados pela espécie são uvas, maçãs e kiwis (Brasil, 1996; Gonzalez, 1983b).

Em algumas culturas, como de uvas cultivadas para vinho e Ribier, de mesa, as populações de $B$. chilensis são bastante numerosas, alcançando níveis de 400-500 ácaros/folha (Gonzalez, 1983a).

* volume, frequência e época das importações

O Chile é o segundo principal exportador de uvas e kiwis e o terceiro principal exportador de maçãs para o Brasil, tendo exportado cerca de $6.440 \mathrm{t}$ de uvas, 2.688,61 t de kiwis e $5.531 \mathrm{t}$ de maçãs para o Brasil de janeiro de 1992 a agosto de 1996 (Anexo B, Tabelas 1, 5 e 3) (Brasil, 1996).

As importações de uvas, maçãs e kiwis do Chile têm sido freqüentes. Foram importados 97 lotes de uvas, 80 lotes de kiwis e 45 lotes de maçãs no período considerado (Anexo B, Tabelas 3, 1 e 5) (Brasil, 1996).

As importações de uvas do Chile têm sido realizadas durante praticamente todo o ano, exceto em setembro, sendo que o maior número de importações foi realizado de fevereiro a maio (Anexo C, Tabela 3). Similarmente, as importações de maçãs do Chile têm sido realizadas durante quase todo o ano, exceto em fevereiro e dezembro, concentrando-se em maio-julho (Anexo C, Tabela 1). As importações de kiwi têm sido realizadas em janeiro e de março a outubro, concentrando-se em maio e agosto-setembro 
(Anexo C, Tabela 5) (Brasil, 1996). Em fevereiro, as populações de B. chilensis em parreirais podem atingir, em algumas variedades, 500 ácaros/folha. Uma quinta geração pode ocorrer no mês de março e parte de abril (Gonzalez, 1983a). Portanto, a maioria das importações de uvas e uma parte das de kiwi do Chile têm sido realizadas em meses de alto risco de infestação destes frutos por $B$. chilensis.

Considerando os parâmetros acima, são grandes as possibilidades de infestação de frutos importados do Chile por B. chilensis.

- possibilidades de sobrevivência da espécie às condições de transporte dos materiais.

Fêmeas fertilizadas de $B$. chilensis entram em diapausa no inverno (Jeppson et al., 1975), podendo suportar condições úmidas e baixas temperaturas e, inclusive, passar alguns meses sob refrigeração, como observado em cachos de uvas no Chile (Gonzalez, 1983a). Portanto, considera-se alta a possibilidade de sobrevivência de fềmeas de $B$. chilensis em diapausa ou prestes a entrar em diapausa às condições de tranporte de uvas e maçãs, que é realizado a baixas temperaturas e altas umidades (Anexo E) (Brasil, 1994).

- possibilidades de deteç̧ão dos ácaros na ocasião da chegada de produtos infestados no Brasil.

\section{* localização na planta hospedeira/produtos}

As fềmeas de $B$. chilensis hibernam principalmente em colônias, sob a casca ou em ranhuras das plantas hospedeiras, mas podem encontrar-se também na inserção dos ramos, em brácteas das gemas, em cicatrizes de pecíolos e em frutos (Gonzalez 1983a; Jeppson et al., 1975). Desta maneira, frutos devem ser inspecionados cuidadosamente para detecção destes ácaros, especialmente cachos de uvas, nos quais os ácaros podem encontrar-se escondidos, no interior dos mesmos, nos pecíolos das bagas. 


\section{* dimensões/ coloração da espécie}

B. chilensis é uma espécie bastante pequena. A fềmea adulta apresenta $400 \mu \mathrm{m}$ de comprimento; o macho é menor que a fêmea. A fêmea adulta é vermelha-escarlate apresentando, às vezes, pequenas manchas escuras na linha mediana anterior. As ninfas são bastante planas, de coloração vermelho-pálido. Os ovos são vermelho-brilhantes, com estrias longitudinais (Gonzalez, 1983a).

A detecção destes ácaros é bastande dificil, especialmente a de ovos, devido às suas reduzidas dimensões. Entretanto, a visualização destes ácaros pode ser facilitada pela coloração viva que a maioria dos estágios de desenvolvimento apresenta.

\section{* apresentação de sintomas em plantas/produtos infestados}

A raquis e o pedicelo do rácimo atacado ficam ressecados e pardos, com estrias escuras que se unem formando manchas alongadas (Gonzalez 1983a; Jeppson et al., 1975). Estes sintomas podem indicar a infestação por B. chilensis.

Consideram-se poucas as possibilidades de deteç̧ão de $B$. chilensis na ocasião da chegada de produtos importados infestados no Brasil, devido às suas reduzidas dimensões, por poderem estar em locais de difícil detecção e pela carência de técnicos adequadamente treinados para detecção de ácaros em material vegetal no Brasil.

\section{- intercepção de B. chilensis em material vegetal em trânsito}

Ácaros desta espécie foram interceptados em limões e uvas de mesa importados do Chile em portos dos EUAN, em muitas ocasiões, quando ainda não se exigia a realização de tratamentos para sua eliminação dos frutos (Gonzalez, 1983a).

Isto reforça as indicações de que frutos chilenos podem estar infestados por B. chilensis e que estes ácaros podem sobreviver às condições de transporte dos mesmos. 


\section{$\Rightarrow$ Potencial de estabelecimento - Alto}

\section{- disponibilidade de hospedeiros}

Os hospedeiros de $B$. chilensis cultivados em maiores extensões no Brasil são: citros, uva, maracujá, maçã e marmelo. A área destinada à colheita destas frutíferas no Brasil em 1994 foi de 992.177 ha, 60.396 ha, 34.715 ha, 27.318 ha e 1.363 ha, respectivamente (Anuário Estatístico do Brasil, 1997).

A maior parte das importações de uvas (87\%), maçãs $(78,6 \%)$ e kiwis $(73,4 \%)$ do Chile têm sido destinadas a São Paulo (Anexo D, Tabelas 3, 1 e 5). Este estado é o principal produtor de citros, o segundo principal produtor de uvas e o quarto principal produtor de maçãs do Brasil. Extensas áreas também são destinadas ao cultivo de maracujá (Anuário Estatístico do Brasil, 1997; Brasil, 1996).

Parte das importações de frutos de kiwi $(13,7 \%)$ e maçãs $(11,5 \%)$ tem sido destinada ao Paraná, onde encontram-se cultivos dos principais hospedeiros de B. chilensis, como uva, citros e maracujá (Anuário Estatístico do Brasil, 1997; Brasil, 1996).

Portanto, há uma grande disponibilidade de hospedeiros para $B$. chilensis nas regiões para onde têm sido destinadas as importações de frutos potencialmente infestados pela espécie.

- adequação das condições climáticas brasileiras para a sobrevivência, desenvolvimento e reprodução da espécie

B. chilensis é encontrado principalmente no sul do Chile, sendo substituído por outra espécie no norte do país, onde o clima é árido (Gonzalez, 1983a; World Meteorological Organization, 1996). Algumas regiões do sul do Chile apresentam condições climáticas semelhantes às do sul do Brasil, onde concentra-se a produção de uva no país. Isto indica que as condições climáticas brasileiras onde concentram-se as áreas de produção do principal hospedeiro de $B$. chilensis são adequadas ao seu desenvolvimento. 
Portanto, considera-se alto o potencial de estabelecimento de $B$. chilensis no Brasil, devido à disponibilidade de hospedeiros e pela adequação das condições climáticas brasileiras ao desenvolvimento da espécie.

\subsubsection{Brevipalpus lewisi McGregor, 1949 (Tenuipalpidae)}

- Nomes vulgares - "ácaro de la roña", "scab mite"; "citrus flat mite"

Distribuição geográfica - América do Norte (Califórnia, Arizona, Maryland, Carolina do Norte - EUAN), Europa (Bulgária, Espanha, Geórgia, Hungria, Iugoslávia, Romênia, Ucrânia), Ásia (Japão, Líbano, Tadiquistão), África (Egito), Oceania (Austrália) (Arias Giralda \& Nieto Calderon, 1985; Bozai, 1976; Iacob, 1978; Jeppson et al., 1975; Livshits et al., 1980; Mijuskovic, 1981; Rice \& Weinberger, 1981; Yousef, 1970).

- Hospedeiros - Anacardiaceae (Pistacia sp.), Juglandaceae (Juglans sp.), Punicaceae (Punica sp.), Rutaceae (Citrus spp.), Vitaceae (Vitis sp.) e plantas ornamentais (Jeppson et al., 1975; Rice \& Weinberger, 1981).

- Características biológicas - Foram observadas 4 gerações por ano na Espanha, Bulgária e California, EUAN (Jeppson et al., 1975; Rodriguez et al., 1987). As fềmeas podem entrar em diapausa durante o inverno (Jeppson et al., 1975). Estudos em parreirais na Austrália mostraram que as populações aumentam cerca de 60 vezes durante uma estação (Buchanan et al., 1980).

$\Rightarrow$ Potencial de importância econômica - Médio

- importância econômica e/ou social de seus hospedeiros no Brasil

Os hospedeiros de $B$. lewisi que apresentam maior importância econômica no Brasil são citros e uva. Os frutos cítricos são os que apresentam maior importância 
econômica no país, em valor de produção (Tabela 1). Além disto, citros estão entre as frutas de peso dominante nas exportações. A uva também é de grande importância econômica para o Brasil (ítem 3.4.1) (Anuário Estatístico do Brasil, 1997; Brasil, 1994).

\section{- danos e perdas causadas devido às infestações pela espécie}

Quase todas as informações encontradas sobre danos causados por infestações de B. lewisi são relativamente antigas.

$\mathrm{Na}$ Austrália, infestações de $B$. lewisi causam sintomas de tumores nas videiras (Buchanan et al., 1980).

Em citros, os danos causados devido às infestações por $B$. lewisi consistem basicamente na redução da qualidade dos frutos. As áreas danificadas por outras pragas, como cigarrinhas ou tripes, quando infestadas pelo ácaro tornam-se conspícuas como cicatrizes de sarna. Quando as infestações são pesadas, grande parte da superfície dos frutos apresenta sintomas (Jeppson et al., 1975).

Em pistachio os danos observados devido à infestações por B. lewisi na Califórnia, EUAN consistem de pústulas ásperas escuras sobre as nozes e sobre os pecíolos dos agrupamentos de nozes. Às vezes, observa-se murcha dos ramos e pecíolos e fendas nas cascas das nozes, que, então, abrem-se prematuramente (Rice \& Weinberger, 1981).

Não se dispõe de informações sobre as perdas quantitativas causadas por infestações de $B$. lewisi, entretanto, esta espécie foi considerada uma praga de videiras na Espanha e Austrália; de citros no Japão e Iugoslávia; de pistachio na Califórnia, EUAN; de plantas ornamentais e árvores em parques em Crimea (Ucrânia), Geórgia e Tadiquistão (CIS) (Buchanan et al., 1980; Jeppson et al., 1975; Livshits et al., 1980 Michailides, 1990; Rodriguez et al., 1987). Na Califórnia , B. lewisi foi uma das principais pragas de citros na década de 1950. Entretanto, devido à utilização de pesticidas organoquímicos, atualmente não é comumente encontrada (Matsumoto \& Elmer, 1983).

Algumas citações consideram a espécie sem importância econômica. Em levantamentos realizados em parreirais na Hungria no período de 1988 a 1990, 
B. lewisi foi encontrado em uma única amostra (Dellei \& Szendrey, 1991). Na Bulgária, $B$. lewisi não é nocivo às parreiras, aparentemente por ser controlado por tratamentos com enxofre utilizados contra fungos (Chak"rov, 1973). No Egito, B. lewisi não é uma especie abundante, quando comparada a outros ácaros-praga (Yousef, 1970). De acordo com Hessein \& Perring (1988), populações de B. lewisi não atingem o status de praga em parreirais na Califórnia devido à baixa taxa de aumento populacional, quando comparada à de tetraniquídeos e à ação de ácaros predadores.

\section{- medidas utilizadas para o controle da espécie}

Assim como as informações encontradas sobre danos causados, a maioria das citações encontradas sobre medidas de controle de $B$. lewisi são relativamente antigas.

Para o controle de $B$. lewisi têm-se utilizado basicamente o controle químico. São poucos os trabalhos relacionados ao controle biológico desta espécie.

$\mathrm{Na}$ Espanha, recomenda-se a realização de tratamentos nos parreirais antes do início de junho, que é considerado o período crítico em que as infestações podem afetar a produção de frutos (Rodriguez et al., 1987). Ensaios de campo conduzidos na Austrália indicaram que os acaricidas mais efetivos para o controle de B. lewisi são dicofol, bromopropilato, dicofol + tetradifom (Goodwin, 1982). Na Hungria, recomendam-se pulverizações com DNOC antes da abertura das gemas; durante a estação de crescimento das videiras, recomendam-se aplicações de formotiom, dimetoato, fosfamidom ou compostos similares, para o controle de ácaros, incluindo B. lewisi (Bozai, 1976). Na Romênia, B. lewisi é controlado em parreirais pelo acaricida específico Anilix (clorfenetol e chlorfensulphide), por cloropropilato ou por clorfensom (Iacob, 1978).

De acordo com Jeppson et al. (1975), os melhores resultados no controle de B. lewisi em citros são obtidos quando enxofre é aplicado no final do inverno e início da primavera. No verão, os danos podem ser evitados por pulverizações com dicofol ou clorobenzilato.

Poucos trabalhos têm sido desenvolvidos visando o controle biológico de B. lewisi. Em laboratório na Califórnia observou-se o ácaro tideídeo Homeopronematus anconai (Baker) alimentando-se de ovos de B. lewisi; o autor sugeriu que o mesmo 
poderia estar ocorrendo em videiras. Este tenuipalpídeo também serve como presa para Galendromus occidentalis (Nesbitt) (Hessein \& Perring, 1988). Na Austrália, B. lewisi é predado pelo fitoseídeo Neoseiulus reticulatus (Oudemans) (Buchanan et al., 1980). O fitoseideo Galendromus mcgregori (Chant) foi encontrado em amostras de pistachio infestadas por $B$. lewisi. A população deste predador aumentou conjuntamente com a de B. lewisi até a época da colheita (Rice \& Weinberger, 1981). Na Austrália, após 3 anos de estudos para averigüar o potencial de utilização de controle biológico para as 3 espécies de ácaros que infestam videiras, incluindo $B$. lewisi, concluiu-se que há um considerável potencial para o desenvolvimento de estratégias de manejo destes ácaros através do controle biológico com ácaros predadores nativos (James, 1992).

A redução das populações de $B$. lewisi pode ser efetuada com a remoção dos ácaros, através da poda das videiras, como observado em parreirais em Victoria, Austrália (Buchanan et al., 1980).

\section{- status quarentenário}

B. Lewisi é considerado uma praga de importância quarentenária para citros, videiras e pistachio pelo COSAVE (Brasil, 1995). Portanto, a simples introdução desta espécie no país pode levar a restrições nas importações de frutos brasileiros por países integrantes do Mercosul. Estes países representam o segundo principal mercado importador de uvas brasileiras, após a Comunidade Européia (Tabela 2) (Brasil, 1994).

Considera-se o potencial de importância econômica de $B$. lewisi médio, pois, apesar de seus principais hospedeiros serem de grande importância econômica no país, são poucas as informações disponíveis sobre danos e perdas causadas pelas infestações e, aquelas encontradas, são relativamente antigas. Da mesma maneira, não encontraram-se muitas referências atuais sobre medidas de controle utilizadas para a espécie. Em alguns países, onde $B$. lewisi causava problemas nas décadas passadas, atualmente não representa mais problema. 
$\Rightarrow$ Potencial de Introdução - Médio

- possibilidades de infestação dos produtos importados nos países de origem

* presença e abundância da espécie nos países exportadores.

Considerando as referências encontradas sobre hospedeiro $\mathrm{x}$ distribuição de B. lewisi e as informações sobre importações de frutos ou mudas no período de janeiro de 1992 a agosto de 1996, os produtos potencialmente infestados por B. lewisi importados pelo Brasil são uvas e mudas de videiras dos EUAN (Brasil, 1996).

B. lewisi não é uma espécie abundante em parreirais nos EUAN. Foram encontradas poucas citações associando esta espécie a uva nos EUAN. A espécie não atinge nível de praga em parreirais na Califórnia (Hessein \& Perring, 1988). Esta espécie foi uma das princiapis pragas de citros nos EUAN, entretanto, com a utilização de novos pesticidas, não é mais comumente encontrada (Matsumoto \& Elmer, 1983). Em referências mais recentes sobre $B$. lewisi neste país, este ácaro é considerado como praga somente em pistachio (Michailides, 1990).

* volume, frequência e época das importações

Os EUAN é o principal exportador de uvas para o Brasil, tendo exportado cerca de $16.100 \mathrm{t}$ no período considerado (Anexo $\mathrm{B}$, Tabela 3). Apesar deste país não ser um dos principais exportadores de mudas de videiras para o Brasil, quantidades consideráveis de mudas foram exportadas nos últimos anos (Anexo B, Tabela 4) (Brasil, 1996).

As importações de uvas dos EUAN têm sido freqüentes, pois foram importados 124 lotes destes frutos no período de janeiro de 1992 a agosto de 1996 (Anexo B, Tabela 3) (Brasil, 1996).

Esta espécie é encontrada em pistachio na Califómia a partir do final de maio. As populações aumentam em julho com o aumento da temperatura, alcançando um pico populacional no final de julho ou início de agosto. Posteriormente, as populações declinam (Rice \& Weinberger, 1981). Não se dispõe de informações sobre a fenologia da 
espécie em parreirais nos EUAN, mas considera-se que apresenta a mesma tendência que em pistachio.

As importações de uvas dos EUAN têm sido realizadas durante praticamente todo o ano, com maior concentração nos meses de junho a setembro, enquanto que as de mudas de videiras foram realizadas em junho e, em maiores quantidades, em dezembro (Anexo C, Tabelas 3 e 4) (Brasil, 1996).

Portanto, a maior parte das importações de uvas dos EUAN e parte das de mudas de videiras têm sido realizadas em meses de picos populacionais $B$. lewisi, sendo alto o risco de infestação destes produtos pela espécie.

Considerando os parâmetros acima, existem possibilidades de infestação de frutos ou mudas de videiras importadas dos EUAN por $B$. lewisi, entretanto, estas não são muitas, pois a espécie não é abundante em parreirais naquele país.

\section{- possibilidades de sobrevivência da espécie às condições de transporte dos materiais.}

Fêmeas adultas de $B$. lewisi entram em diapausa no inverno (Rice \& Weinberger, 1981; Rodriguez et al., 1987), sendo bastante resistentes a baixas temperaturas neste período. Isto indica que há possibilidades de fềmeas hibernantes ou aquelas que fossem migrar para os locais de hibernação, porventura associadas aos cachos de uvas, sobreviverem às condições de transporte dos mesmos, que é realizado a baixas temperaturas e altas umidades (Anexo E) (Brasil, 1994).

Ácaros da espécie associados a mudas de videiras apresentam grande possibilidade de sobreviver durante o transporte das mesmas.

Portanto, considera-se alta a possibilidade de sobrevivência de $B$. lewisi às condições de tranporte dos produtos potencialmente infestados. 
- possibilidades de deteç̧ão dos ácaros na ocasião da chegada de produtos infestados no Brasil.

\section{* localização na planta hospedeira}

B. lewisi oviposita ao longo das nervuras principais das folhas de videiras (Iacob, 1978). Na Espanha, estes ácaros foram mais abundantes na base dos rebentos no início das infestações, mas no final de agosto concentraram-se nas folhas dos brotos axilares (Arias Giralda \& Nieto Calderon, 1985). Na Austrália, os ácaros foram observados em todas as partes verdes das plantas no final da estação de desenvolvimento das mesmas (Buchanan et al., 1980). As fềmeas adultas podem hibernar em diversos locais das videiras ou entre folhas mortas no solo (Arias Giralda \& Nieto Calderon, 1985).

Portanto, deve-se proceder uma detalhada inspeção dos materiais, pois os ácaros podem estar em qualquer porção das plantas. É necessário um cuidado especial para a detecção de ovos, pois estes podem passar desapercebidos quando estiverem nas porções laterais inferiores das nervuras principais.

\section{* dimensões/coloração da espécie}

Como outros ácaros, as diversas formas de desenvolvimento de $B$. lewisi são bastante pequenas. As fềmeas de populações norte-americanas medem 256-279 $\mu \mathrm{m}$ e as mexicanas 274-302 $\mu \mathrm{m}$ de comprimento (Baker \& Tuttle, 1987).

Portanto, a deteç̧ão destes ácaros é dificultada por suas reduzidas dimensões, especialmente a de ovos.

\section{* apresentação de sintomas em plantas/produtos infestados}

B. lewisi causa sintomas semelhantes a lesões (tumores), conhecidos como "mite bunch" em videiras (Buchanan et al., 1980). Estas lesões podem sinalizar a presença dos ácaros.

Consideram-se pequenas as possibilidades de detecção de $B$. lewisi em frutos ou mudas de videiras devido às suas reduzidas dimensões, por poderem estar em locais 
protegidos nas plantas/frutos e, principalmente, devido à carência de técnicos adequadamente treinados para deteç̧ão de ácaros em material vegetal.

\section{- intercepção de B. lewisi em material vegetal em trânsito}

Ácaros da espécie foram interceptados no porto da Cidade do Cabo, África do Sul, em estacas de uvas originárias da Califórnia, EUAN (Meyer, 1979).

Esta intercepção poderia indicar a possibilidade de infestação de mudas de videiras por B. lewisi nos EUAN. Entretanto, os níveis populacionais que a espécie alcançava a algumas décadas não são os mesmos que alcança atualmente (Matsumoto \& Elmer, 1983).

Portanto, o potencial de introdução de $B$. lewisi no Brasil através de importações de uvas ou mudas de videiras dos EUAN é considerado médio, pois, apesar da dificil detecção destes ácaros e das possibilidades de sobrevivência às condições de transporte dos produtos potencialmente infestados, a possibilidade de infestação dos produtos não é grande, pois a espécie não é abundante em parreirais nos EUAN.

$\Rightarrow$ Potencial de estabelecimento - Alto

\section{- disponibilidade de hospedeiros}

Os hospedeiros de B. lewisi cultivados em maiores extensões no Brasil são: citros, uva e noz. A área destinada à colheita destas frutíferas no Brasil em 1994 foi de 992.177 ha, 60.396 ha e 2.514 ha, respectivamente (Anuário Estatístico do Brasil, 1997).

A quase totalidade das importações de uvas pelo Brasil têm sido destinada a São Paulo (98,69\%). Este estado é o principal produtor de citros e o segundo principal produtor de uvas no Brasil (Anuário Estatístico do Brasil, 1997; Brasil, 1996).

As mudas de videiras importadas dos EUAN pelo Brasil têm sido destinadas, em sua maior parte, ao Rio Grande do Sul $(83,3 \%)$ e, em menor proporção, à Bahia $(16,67 \%)$; ambos são importantes produtores da cultura no país. O Rio Grande do Sul é 
o principal produtor de uvas e nozes. A Bahia, atualmente, é o quarto principal produtor de uvas (Anuário Estatístico do Brasil, 1997; Brasil, 1996).

\section{- uso proposto}

Considera-se alto o potencial de estabelecimento de ácaros porventura associados a mudas de videiras.

- adequação das condições climáticas brasileiras para a sobrevivềncia, desenvolvimento e reprodução da espécie

Períodos de temperaturas extremamente altas e baixas umidades relativas não têm influência deletéria sobre as populações de B. lewisi (Jeppson et al., 1975). Isto indica que $B$. lewisi pode se adaptar às condições de cultivo de uva na região nordeste do Brasil, onde as temperaturas normalmente são bastante elevadas e a umidade relativa é baixa (Brasil, 1992).

\section{- potencial reprodutivo}

B. lewisi apresenta 4 gerações por ano na Espanha, Bulgária e Califórnia, EUAN (Jeppson et al., 1975; Rodriguez et al., 1987). Portanto, o número de gerações de $B$. lewisi por ano é relativamente alto.

O potencial de estabelecimento de $B$. lewisi no Brasil é considerado alto, pois há grande disponibilidade de hospedeiros para a espécie, principalmente nas regiões para onde os produtos potencialmente infestados têm sido destinados. Em uma análise preliminar, $B$. lewisi pode se adaptar às condições climáticas de ao menos uma importante região produtora de uva no Brasil, a de Petrolina-Juazeiro no nordeste.

Atualmente, B. lewisi é listado como praga de importância quarentenária para o Brasil e países do cone sul. Entretanto, faltam informações sobre a importância econômica da espécie nas regiões onde ocorre para justificar, com argumentos suficientes, seu status quarentenário para o país. 


\subsubsection{5. - Bryobia rubrioculus (Scheuten, 1857) (Tetranychidae)}

- Sinônimos - Sannio rubrioculus Scheuten, 1857; Bryobia bioculus Amerlind, 1862; Bryobia pyri Boisduval, 1867; Bryobia goriensis Reck, 1947; Bryobia redikorzevi Reck, 1947; Bryobia arborea Morgan \& Anderson, 1957 (Flechtmann ${ }^{17}$ ) .

> Nomes vulgares - "brown mite", "brown fruit tree mite", "brown almond mite", "arañuela parda", "arañuela parda de los frutales"

- Distribuição geográfica - América do Norte (Canadá, EUAN, México); América do Sul (Argentina, Chile, Colômbia, Uruguai); Europa (Alemanha, Áustria, Azerbaijão, Bélgica, Bulgária, Dinamarca, Eslováquia, Espanha, Finlândia, França, Geórgia, Grécia, Holanda, Hungria, Ilha da Madeira, Inglaterra, Irlanda, Itália, Iugoslávia, Lituânia, Moldóvia, Polônia, Portugal, Romênia, Rússia, Suiça, Tchecoslováquia, Ucrânia), Ásia (China, Coréia, Irã, Iraque, Japão, Kasaquistão, Líbano, Paquistão, Turquia), África (África do Sul, Argélia, Egito, Marrocos, Moçambique, Zimbabwe), Oceania (Austrália, Nova Zelândia, Tasmânia) (Flechtmann ${ }^{17}$; Jeppson et al., 1975).

- Hospedeiros - Asteraceae (Conyza canadensis), Betulaceae (Carpinus betulus, Corylus sp.), Caprifoliaceae (Diervilla sp., Lonicera canadensis, L. xylosteum, L. sp.), Chenopodiaceae (Sarcobatus vermiculatus), Cupressaceae (Juniperus sp.), Fabaceae (Medicago sativa, Pisum sativum, Vicia faba), Fagaceae (Quercus borealis), Juglandaceae (Juglans regia), Moraceae (Ficus sp.), Pinaceae (Pinus sp.), Rosaceae (Cydonia oblonga, Eriobotrya japonica, Fragaria sp., Malus domestica, M. purpurea, M. sp., Potentilla fragarioides, Prunus americana, P. armeniaca, P. avium, P. cerasus, $P$. divaricata, $P$. domestica, $P$. dulcis, $P$. insititia, $P$. persica, $P$. serrulata, P. spinosa, Pyrus joponica, P. pyrifolia, P. sp., Rubus sp.), Rutaceae (Citrus reticulata), Salicaceae

\footnotetext{
${ }^{17}$ FLECHTMANN, C. H. W. (Pesquisador CNPq, Depto. Zoologia, ESALQ, Universidade de São Paulo, Piracicaba, SP). Comunicação pessoal, 1997.
} 
(Populus tremula, P. tremuloides, Salix sp.), Tiliaceae (Tilia sp.), Ulmaceae (Ulmus americana, U. sp.,), Vitaceae (Vitis sp.) (Flechtmann ${ }^{18}$; Mitrofanov \& Sharonov, 1986).

- características biológicas: Sob condições controladas no Canadá, a $10^{\circ} \mathrm{C}, 12,8^{\circ} \mathrm{C}$, $15,5^{\circ} \mathrm{C}$ e $18,3^{\circ} \mathrm{C}$ a fase imatura de $B$. rubrioculus durou $34,26,18$ e 17 dias, respectivamente (Herbert, 1962). A produção de fềmeas de primeira geração é de 20 ovos/fềmea, diminuido até a última geração, com uma média de 7 ovos/fềmea, entretanto, uma fềmea pode produzir até 78 ovos (Jeppson et al., 1975; Lienk et al., 1980). O número de gerações varia bastante entre os países, sendo de 2 a 4 nos EUAN e Canadá, 3 na Inglaterra, 3 a 4 no Líbano, 6 na África do Sul e 6 a 7 no sul da antiga USSR (Anderson \& Morgan, 1958; Herbert, 1962; Jeppson et al., 1975; Inglaterra, 1985). A espécie se reproduz partenogeneticamente (Lienk et al., 1980; University of California, 1991).

\section{$\Rightarrow$ Potencial de importância econômica - Médio}

- importância econômica e/ou social de seus hospedeiros no Brasil

Os principais hospedeiros de $B$. rubrioculus que apresentam importância econômica no Brasil são: maçã, pêra, pêssego e ameixa. A maçã é uma frutífera de grande importância econômica para o Brasil (ítem 3.4.1) (Anuário Estatístico do Brasil, 1997; Brasil, 1994). A cultura de pêssegos no Brasil também é importante, ocupando a décima primeira posição entre as frutíferas, em valor de produção (Anuário Estatístico do Brasil, 1997). A cultura da ameixa vem se expandindo no país.

\section{- danos e perdas causadas devido às infestações pela espécie}

Observou-se em pomares de maçã e pêssego na Argentina que, quando as infestações começam no início do desenvolvimento das gemas, podem afetar a produção de frutos. Entretanto, quando tardias, podem passar desapercebidas (Simons, 1964). O

\footnotetext{
${ }^{18}$ FLECHTMANN, C. H. W. (Pesquisador CNPq, Depto. Zoologia, ESALQ, Universidade de São Paulo, Piracicaba, SP). Comunicação pessoal, 1997.
} 
mesmo foi observado em British Columbia, Canadá, onde danos causados às folhas e gemas florais retardaram a abertura das flores (Anderson \& Morgan, 1958).

Infestações de $B$. rubrioculus em cultura de amêndoas na Califórnia, EUAN podem causar severo mosqueamento na folhagem e até mesmo desfolha (Hoy, 1985; Summers \& Stocking, 1972). Infestações por densas populações podem levar a uma redução de cerca de $30 \%$ na área folhar, quando ocorrem após o período da queda das pétalas (Summers \& Stocking, 1972). Entretanto, geralmente os danos causados por esta espécie são limitados, já que normalmente ocorrem apenas 2 gerações por ano (Hoy, 1985).

As informações encontradas sobre o efeito das infestações de $B$. rubrioculus no desenvolvimento de frutos são contraditórias. De acordo com Anderson \& Morgan (1958) e Barnes \& Madsen (1961) na Califórnia e British Columbia, intensos danos folhares devido às infestações em macieiras resultam na diminuição do tamanho e retardam o amadurecimento dos frutos. Entretanto, de acordo com informações mais recentes, a alimentação dos ácaros raramente é suficientemente severa para afetar o crescimento dos frutos (University of California, 1991).

Não foram encontrados dados quantitativos sobre as perdas causadas por B. rubrioculus. De uma maneira geral, esta espécie é considerada uma praga de frutíferas de folhas decíduas que apresenta ampla distribuição, encontrando-se na América do Norte e do Sul, Europa, África do Sul, Austrália e Ásia (Jeppson et al., 1975; University of California, 1991).

Nos EUAN, B. rubrioculus era considerada a principal espécie de ácaro em pomares de maçã nas regiões montanhosas do sul da Califórnia; também era freqüente em culturas de amêndoas, pêssegos, ameixa e pêra (Barnes \& Madsen, 1961). Mais recentemente, esta espécie foi relatada causando problemas somente em amêndoas, nesta mesma região (Hoy, 1985). Segundo Lienk et al. (1980), B. rubrioculus não é de importância econômica em pomares de maçã em Nova York, tendo atingido status de praga apenas em algumas ocasiões no Vale de Hudson. Também em Wisconsin e Carolina do Norte, maiores populações eram encontradas somente em pomares não pulverizados (Farrier et al., 1980; Oatman, 1973). No Canadá, a espécie é encontrada em 
praticamente todos os pomares, especialmente naqueles abandonados, mas raramente apresenta importância econômica (Amano \& Chant, 1990; Anderson \& Morgan, 1958; Herbert, 1962).

$\mathrm{Na}$ América do Sul, é relatada a presença de $B$. rubrioculus infestando frutíferas na Argentina e Chile. No Chile, esta espécie era dominante antes da utilização de organofosforados, mas atualmente, quase desapareceu, tendo sido substituída por Panonychus ulmi (Koch) e Tetranychus urticae Koch (Gonzalez, 1981).

Como no Chile, B. rubrioculus era a espécie dominante na Itália e foi substituida por P. ulmi, provavelmente devido à intensiva aplicação de pesticidas (Kremer, 1971). $\mathrm{Na}$ Inglaterra, esta espécie é uma praga ocasional de maçã (Inglaterra, 1985). Em Geórgia, Rússia e Azerbaijão (CIS), os autores referiam-se à espécie como uma das mais nocivas e comuns, na década de 1960 e 1970 (Anfinnikov, 1979; Daneshvar, 1978; Loladse, 1989). Na Polônia, em levantamentos realizados em pomares de ameixa e maçã, B. rubrioculus foi uma espécie bastante comum, sendo encontrada em $55,9 \%$ e $78,4 \%$ das amostras infestadas, respectivamente (Skorupska, 1976 e 1979). Em pomares de maçã não tratados por mais de 10 anos na Alemanha, desenvolveram-se grandes populações de $B$. rubrioculus (Karg, 1971). Na Bulgária, em trabalhos realizados na década de 1970, esta espécie foi considerada uma das pragas mais importantes de frutíferas, juntamente com P. ulmi (Chak"rov, 1970). Na Espanha, B. rubrioculus é uma praga de frutiferas, juntamente com $P$. ulmi e T. urticae (Vinuela, 1984).

$\mathrm{Na}$ Ásia, a maioria dos trabalhos referindo-se a B. rubrioculus como praga são da década de 1970 (Iren \& Okul, 1974; Smol'Yannikov, 1970). Em Crimea, Ucrânia (CIS), esta espécie foi substituida por Amphitetranychus viennensis (Zacher) quando DDT foi substituido por organofosforados (Galetenko, 1978).

\section{- medidas utilizadas para o controle da espécie}

Comumente, B. rubrioculus é controlada quando os ácaros encontram-se em dormência, no estágio de ovo (University of California, 1991). Na Califórnia, pulverizações com óleo e organofosforados controlaram os ovos hibernantes, não sendo necessário o controle na estação seguinte (Hoy, 1985). Em CIS, preparações de óleo 
mineral a $4-5 \%$ resultou em mais de $95,6 \%$ de controle dos ovos de $B$. rubrioculus (Abdullaev \& Mugutdinov, 1976).

Em pomares de macieiras, na Romênia, os resultados de ensaios visando o controle de B. rubrioculus e $P$. ulmi mostraram que os produtos mais efetivos foram óxido de fenbutatinaa e propargite, como ovicidas; clorfensom + propargite; dicofol + cihexatina; bromopropilato; amitraz e oxitetraciclina (Iacob et al., 1980). Também em macieiras, na Turquia, bons resultados foram obtidos utilizando um óleo de emulsão e pulverizações com azinfós-metila, malatiom, paratiom, fentiom, dimetoato, fenitrotiom e demetom metila para o controle de ninfas de verão desta espécie (Iren \& Okul, 1974).

Entre os acaricidas testados para o controle de B. rubrioculus, em CIS, dimetoato aplicado antes da brotação e após a floração resultou em $98,2 \%$ de controle e seu efeito durou por 45-50 dias (Abdullaev \& Mugutdinov, 1976).

Não tem sido relatado o desenvolvimento de resistência a pesticidas em populações de $B$. rubrioculus. Em pomares de amêndoas na Califórnia, populações desta espécie expostas à forte pressão de seleção de organofosforados não desenvolveram resistência a estes produtos (Hoy, 1985). Sob alta pressão química, a atividade de B. rubrioculus foi reduzida na Ucrânia, diferentemente de $A$. viennensis e $P$. ulmi, que passaram a causar mais danos (Akimov et al., 1994).

Apenas têm sido realizados trabalhos básicos sobre controle biológico de B. rubrioculus. Nos EUAN e Canadá, os ácaros predadores de B. rubrioculus são: Amblydromella rhenana (Oudemans), Typhlodromus pyri Scheuten, Euseius finlandicus (Oudemans), Phytoseius macropilis (Banks), Typhlodromus corticis Herbert e Galendromus mcgregori (Chant) (Croft \& Jorgensen, 1977; Herbert, 1959; Jeppson et al., 1975). O fitoseídeo $P$. macropilis também foi observado predando $B$. rubrioculus em pomares de macieiras na Alemanha (Karg, 1971). Na Nova Zelândia o ácaro estigmeídeo Agistemus longisetus Gonzalez foi relatado predando esta espécie (Jeppson et al., 1975). Além de ácaros predadores, alguns insetos também predam $B$. rubrioculus. $O$ tripes Haplothrips faurei Hood é considerado um dos predadores mais importantes da espécie em Ontario, Canadá, enquanto o mirídeo Campylomma livida Reut. mostrou-se importante no controle da espécie na Austrália (Jeppson et al., 1975; Readshaw, 1975). 
O potencial de importância econômica de $B$. rubrioculus é considerado médio. Não têm sido relatados, nos últimos anos, problemas sérios causados pelas infestações desta espécie. Apenas raramente $B$. rubrioculus tem atingido status de praga em pomares. Esta espécie era dominante em pomares de frutíferas de folhas decíduas em diversos países, entretanto, foi substituída por outras espécies, devido à mudanças nos grupos químicos dos produtos utilizados nas culturas, e, em alguns deles, atualmente é raramente encontrada.

$\Rightarrow$ Potencial de Introdução - Médio

- possibilidades de infestação dos produtos importados nos países de origem

* presença e abundância da espécie nos países exportadores.

B. rubrioculus ocorre em vários países exportadores de material vegetal potencialmente infestado. As principais vias de ingresso da praga no país, considerando as referências sobre hospedeiro/país e os dados de importação de produtos vegetais, são: maçãs dos EUAN, Inglaterra, Argentina, Chile, Canadá e Espanha; cerejas e pêras dos EUAN e pêssegos da Argentina (Anexo B, Tabelas 1, 2, 6 e 7).

Atualmente, B. rubrioculus é uma especie abundante em pomares abandonados ou não-tratados e, normalmente, não tem apresentado importância econômica em pomares comerciais nos EUAN e Canadá, exceto em culturas de amêndoas (Amano \& Chant, 1990; Farrier et al., 1980; Herbert, 1962; Hoy, 1985; Lienk et al., 1980; Oatman, 1973).

Não se dispõe de informações sobre a abundância de $B$. rubrioculus na Argentina. Atualmente, a espécie é raramente encontrada no Chile (Gonzalez, 1981).

Na Inglaterra, B. rubrioculus é uma praga ocasional de maçãs e, na Espanha, é uma praga de frutíferas juntamente com P. ulmi e T. urticae (Inglaterra, 1985; Vinuela, 1984). 
B. rubrioculus é raramente encontrada em alguns países exportadores de frutos potencialmente infestados, como o Chile. Em outros países, a espécie não tem atingido níveis de praga ou isto tem ocorrido ocasionalmente, mas deve-se considerá-la relativamente abundante nos pomares.

* volume, frequência e época das importações

O volume das importações de frutos potencialmente infestados por B. rubrioculus é bastante grande.

A Argentina é o principal exportador de maçãs e o quarto principal exportador de pêssegos para o Brasil A frequência das exportações têm sido alta; no período de janeiro de 1992 a agosto de 1996 foram importados 419 lotes de maçãs e 24 lotes de pêssegos pelo Brasil (Anexo B, Tabelas 1 e 6). As importações de maçãs da Argentina pelo Brasil têm sido realizadas durante todo o ano (Anexo C, Tabela 1) (Brasil, 1996).

Os EUAN é o segundo principal exportador de maçãs, pêras e cerejas para o Brasil. A frequência das exportações têm sido alta, tendo sido importados 49 lotes de maçãs, 80 de pêras e 84 de cerejas no periodo considerado (Anexo B, Tabelas 1,2 e 7). As importações de maçãs e pêras dos EUAN têm ocorrido durante praticamente todo o ano (Anexo C, Tabelas 1 e 2). As exportações de cerejas dos EUAN para o Brasil têm sido realizadas no período de abril-agosto e novembro (Anexo C, Tabela 6) (Brasil, 1996).

O Chile é o terceiro principal exportador de maçãs para o Brasil, após Argentina e EUAN e as exportações têm sido freqüentes, tendo sido exportados 45 lotes de maçãs no período considerado (Anexo B, Tabela 1), distribuidos ao longo do ano, exceto em fevereiro e dezembro (Anexo C, Tabela 1) (Brasil, 1996).

Não se dispõe de informações sobre a época de ocorrência de picos populacionais da espécie nos países exportadores de frutos para o Brasil. Como as importações têm sido realizadas durante praticamente todo o ano, considera-se que parte das importações têm sido realizadas em épocas de alto risco de infestação dos frutos. 
Portanto, as possibilidades de infestação de frutos por B. rubrioculus nos países exportadores em que a espécie ocorre são muitas. Apesar da espécie não atingir níveis populacionais de praga na maioria destes países, sua presença não é rara. Grandes volumes de frutos potencialmente infestados pela espécie têm sido importados pelo Brasil, em alta freqüência e durante praticamente todo $o$ ano.

- possibilidades de sobrevivência da espécie às condições de transporte dos materiais.

Ovos de $B$. rubrioculus entram em diapausa no outono/inverno e são extremamente resistentes a baixas temperaturas neste período, pois podem permanecer viáveis até temperaturas de $-27^{\circ} \mathrm{C}$ (Jeppson et al., 1975). Há possibilidades de que frutos colhidos estejam infestados por ovos em diapausa. Portanto, há possibilidades de que estes ovos sobrevivam às condições de transporte de frutos de clima temperado, que é realizado a temperaturas próximas a $0^{\circ} \mathrm{C}$ e alta umidade relativa (Anexo E) (Brasil, 1994).

- possibilidades de detecção dos ácaros na ocasião da chegada de produtos infestados no Brasil.

* localização no hospedeiro/produtos importados

Os ovos de $B$. rubrioculus são encontrados na superficie inferior das folhas de maçã, nas proximidades das nervuras da base das folhas, pecíolos, espinhos dos ramos e na casca de ramos novos. Com o passar da estação, encontram-se ovos também ao longo da nervura central da superficie superior das folhas e na região do final do cálice das maçãs. (Jeppson et al., 1975).

Para a detecção de ovos de $B$. rubrioculus em frutos é necessária uma cuidadosa inspeção, especialmente na região do final do cálice, onde estes podem estar protegidos. 
* dimensões/ coloração da espécie

Os ovos de $B$. rubrioculus são bastante pequenos, medindo cerca de $170 \mu \mathrm{m}$ de diâmetro, esféricos e de coloração vermelho-brilhante (Lienk et al., 1980). As fêmeas medem cerca de $741 \mu \mathrm{m}$ de comprimento, incluindo o rostro (Baker \& Tuttle, 1994). As larvas são vermelho-alaranjadas e após a alimentação tornam-se verde-escuras (Jeppson et al., 1975). O corpo do adulto é achatado dorso-ventralmente e apresentam coloração marrom bronzeada ou verde escura, com as pernas âmbar. Esta espécie distingue-se das outras que infestam macieiras pelo fato das pernas anteriores se estenderem para frente, serem muito longas e apresentarem maiores dimensões (Barnes \& Madsen, 1961).

É necessária uma cuidadosa inspeção de frutos para a detecção de B. rubrioculus, especialmente de ovos, devido à suas reduzidas dimensões. A coloração viva da maioria dos estágios de desenvolvimente da espécie pode dificultar sua detecção, como no caso de frutos de coloração vermelha, como maçãs ou cerejas.

\section{* apresentação de sintomas em plantas/produtos infestados}

Não se dispõe de informações sobre sintomas apresentados em frutos devido às infestações por B. rubrioculus. Estes ácaros não produzem teia (Barnes \& Madsen, 1961).

Consideram-se poucas as possibilidades de detecção de $B$. rubrioculus em frutos infestados devido às suas reduzidas dimensões, por normalmente encontrarem-se em locais abrigados nos mesmos e pela carência de técnicos adequadamente treinados para a detecção de ácaros em material vegetal no Brasil.

$\Rightarrow$ Potencial de estabelecimento - Médio

\section{- disponibilidade de hospedeiros}

Os principais hospedeiros de $B$. rubrioculus cultivados no Brasil são: maçã, pêra, ameixa, pêssego, marmelo e noz. A maioria destas frutíferas são cultivadas em áreas extensas no país, como maçãs, cultivadas em 27.318 ha; pêssegos, em 20.188 ha; nozes, 
em 2.514 ha; pêras, em 2.303 ha e marmelo, em 1.363 ha (Anuário Estatístico do Brasil, 1997).

Os maiores volumes de importações de maçãs dos EUAN têm sido destinados a São Paulo, Santa Catarina e Paraná (Anexo D,Tabela 1), os quais estão entre os principais produtores de maçãs e pêssegos. Também, São Paulo e Paraná são importantes produtores de pêras no Brasil (Anuário Estatístico do Brasil, 1997).

Todas as importações de maçãs do Canadá e Espanha, a quase totalidade das de cerejas dos EUAN $(97,8 \%)$ e a maior parte das de pêssegos da Argentina $(73,5 \%)$ têm sido destinadas a São Paulo, importante produtor de maçãs, pêssegos e pêras (Anexo D, Tabelas 1, 6 e 7) (Anuário Estatístico do Brasil, 1997; Brasil, 1996).

Todas as importações de maçãs da Inglaterra e parte das de pêssegos da Argentina $(18,8 \%)$ têm sido destinadas ao Rio Grande do Sul, onde encontram-se extensas áreas de maçã, sendo atualmente o principal produtor. Este estado também é o principal produtor de pêssegos, nozes e pêras (Anexo D, Tabela 1, 7) (Anuário Estatístico do Brasil, 1997; Brasil, 1996).

A maior parte das importações de maçãs do Chile vêm sendo destinadas a São Paulo $(78,6 \%)$ e Paraná $(11,5 \%)$, que estão entre os principais produtores de maçãs, pêssegos e pêras. Diferentemente, a maior parte das importações de maçãs da Ạgentina, que é o principal exportador desta fruta para o Brasil, destina-se a Pernambuco, onde não encontram-se cultivos destas culturas (Anexo D, Tabela 1) (Anuário Estatístico do Brasil, 1997; Brasil, 1996).

Portanto, há grande disponibilidade de hospedeiros para $B$. rubrioculus nos estados para onde a maioria das importações de frutos potencialmente infestados têm sido destinadas.

- adequação das condições climáticas brasileiras para a sobrevivência, desenvolvimento e reprodução da espécie

A maioria das larvas eclodem quando as temperaturas alcançam 19 a $27^{\circ} \mathrm{C}$. Temperaturas muito altas ou baixas causam uma diminuição na emergência de larvas e, também, a porcentagem diminui bruscamente quando a umidade é superior a $80 \%$. 
Temperaturas acima de $36^{\circ} \mathrm{C}$ na Nova Scotia aparentemente não tem efeitos nocivos sobre os adultos. Entretanto, no Líbano, climas quentes em julho e agosto destroem muitos dos estágios ativos, reduzindo a população. Períodos extensos de chuva influenciam negativamente o desenvolvimento de populações por matar os ácaros ou retardar o desenvolvimento dos estágios imaturos. Altas temperaturas no início da estação são favoráveis ao aumento populacional (Jeppson et al., 1975).

As infestações mais sérias de $B$. rubrioculus redikorzevi - subespécie que ocorre na Bulgária, Hungria, Iugoslávia e CIS - ocorrem quando a umidade relativa é de 61 a $69 \%$, e as infestações não se tornam tão sérias nas áreas com umidade relativa acima de $70 \%$ - condições relativamente secas são mais favoráveis para o desenvolvimento populacional (Jeppson et al., 1975).

$\mathrm{Na}$ Califórnia, EUAN, observou-se que grandes populações geralmente limitam-se às áreas mais frias de produção de amêndoas (Hoy, 1985).

Em British Columbia, Canadá, danos mais evidentes por B. rubrioculus foram observados no final do verão, especialmente em estações de baixa pluviosidade (Anderson \& Morgan, 1958).

As principais regiões de produção de fruteiras de clima temperado, principais hospedeiros de B. rubrioculus, no Brasil são a Sul e Sudeste (São Paulo). Estas regiões são caracterizadas por climas úmidos, onde a umidade relativa do ar geralmente é próxima ou superior a 70\% (Brasil, 1992).

Portanto, as condições climáticas das regiões brasileiras onde os principais hospedeiros de $B$. rubrioculus são cultivados não são favoráveis ao desenvolvimento de populações numerosas da espécie.

\section{- potencial reprodutivo}

A fecundidade média de fềmeas de $B$. rubrioculus é relativamente baixa. A produção de fêmeas de primeira geração é de 20 ovos/fềmea, diminuido até a última geração, com uma média de 7 ovos/fềmea (Jeppson et al., 1975; Lienk et al., 1980). 
O número de gerações de $B$. rubrioculus por ano é bastante variável entre os países, ocorrendo apenas 2 nos EUAN e Canadá e 6 a 7 no sul da antiga USSR (Anderson \& Morgan, 1958; Herbert, 1962; Jeppson et al., 1975; Inglaterra, 1985).

Portanto, considera-se médio o potencial reprodutivo de $B$. rubrioculus.

Apesar da grande disponibilidade de hospedeiros para B. rubrioculus nas regiões para onde a maioria dos frutos potencialmente infestados pela espécie têm sido destinados, o potencial de estabelecimento da espécie é considerado médio, devido à inadequação das condições climáticas brasileiras, onde seus hospedeiros são cultivados, para o desenvolvimento de grandes populações e ao médio potencial reprodutivo da espécie.

\subsubsection{Cenopalpus pulcher (Canestrini \& Fanzago, 1876) (Tenuipalpidae)}

- Sinônimos - Cenopalpus oudemansi (Hatzinikolis \& Emmanouel, 1987), Cenopalpus pyri (Hatzinikolis \& Emmanouel, 1987), Brevipalpus pulcher (Canestrini \& Fanzago)

- Nome vulgar - "flat scarlet mite"

- Distribuição geográfica - Europa (Alemanha, Áustria, Azerbaijão, Bulgária, Dinamarca, Geórgia, Holanda, Hungria, Inglaterra, Itália, Portugal, Ucrânia, ), Ásia (Afeganistão, Chipre, Índia, Irã, Iraque, Israel, Líbano, Paquistão, Síria, Tadiquistão, Turquemenistão, Turquia) e África (Argélia, Egito, Líbia) (Bozai, 1986; Daneshvar, 1978; Elmosa, 1971; Jeppson et al., 1975; Khanov, 1978; Livshits et al., 1980; Menon et al., 1971; Mohyuddin, 1992)

- Hospedeiros - Coniferae, Juglandaceae (Juglans regia), Rosaceae (Cydonia oblonga, Malus domestica, M. sylvestris, Prumus armeniaca, P. domestica, Pyrus sp.) e plantas 
ornamentais (El Halawany et al., 1990; Gutierrez et al., 1989; Jeppson et al., 1975; Meyer, 1979).

- Características biológicas - No Egito, uma geração de ovo a ovo foi completada em uma média de 38,3 dias a $25,5^{\circ} \mathrm{C}$ e em 25,8 dias a $29,2^{\circ} \mathrm{C}$. A reprodução é sexuada (Zaher et al., 1974). Na Europa, observa-se apenas 1 geração por ano, enquanto que no Irã e Iraque observam-se 3 gerações por ano (Elmosa, 1971; Meyer, 1979; Sepasgosarian, 1970).

$\Rightarrow$ Potencial de importância econômica - Médio

- importância econômica e/ou social de seus hospedeiros no Brasil

Os hospedeiros de C. pulcher de importância econômica no Brasil são maçã, pêra, marmelo e noz. A cultura da maçã é de grande importância econômica para o Brasil (ítem 3.4.1) (Anuário Estatístico do Brasil, 1997; Brasil, 1994). A cultura da ameixa vem se expandindo no país.

- danos e perdas causadas devido às infestações pela espécie

Estes ácaros normalmente alimentam-se nas proximidades das nervuras principais e sobre o pecíolo folhar (Bayan, 1984).

Não se dispõe de informações sobre danos e perdas causadas por infestações de C. pulcher. Entretanto, este ácaro é considerado uma praga de frutíferas decíduas, principalmente maçã e marmelo no Egito (Zaher et al., 1974); de maçã no Líbano (Bayan, 1984); de plantas ornamentais e árvores em parques em Crimea (Ucrânia), Georgia e Tadiquistão (CIS) (Livshits et al., 1980); uma das espécies de ácaros mais nocivas no Azerbaijão (CIS) (Daneshvar, 1978) e uma praga ocasional de maçã, pêra, ameixa e noz na Inglaterra e países europeus (Jeppson et al., 1975).

- medidas utilizadas para o controle da espécie

Para o controle de $C$. pulcher têm-se utilizado basicamente o controle químico. 
No Egito, os resultados de ensaios realizados em pomares de maçã indicaram que clorobenzilato, clordimeform, dicofol, dimetoato e pirimifós-metila controlam satisfatoriamente C. pulcher ( $\mathrm{El}$ Kady et al., 1977a). Entre estes pesticidas, clorobenzilato e clordimeform deram os melhores resultados no controle desta espécie (EL Kady et al., 1977). Em pomares de pêra e damasco, o acaricida dicofol deu o melhor controle de C. pulcher e Brevipalpus lanceolatisetae (Attiah) (Soliman et al., 1974).

Para o controle de $C$. pulcher no Irã recomendam-se, no inverno, pulverizações com dinoseb-amonium, e no verão, metidatiom, binapacril e dinobutom (Sepasgosarian, 1970).

$\mathrm{Na}$ Turquia, os piretróides lambda-cialotrina e fenpropatrina, utilizados para o controle de Cydia pomonella L. em macieiras, também suprimiram as populações de C. pulcher (Bulut et al., 1992b).

Em relação ao controle biológico de $C$. pulcher, poucos trabalhos têm sido realizados. No Egito, observou-se que os ácaros Typhlodromips swirskii (Athias-Henriot) e Pronematus ubiquitus (McGregor) predam C. pulcher e parecem desempenhar um papel importante no controle da espécie em macieiras e pereiras; em damasco, Typhlodromips enab (El-Badry) foi um predador bastante efetivo de C. pulcher (El Halawany et al., 1990; Zaher et al., 1971). Na França, em coníferas, os ácaros predadores Amblydromella rhenanoides (Athias-Henriot), Kampimodromus aberrans (Oudemans) e Cheletomimus berlesei (Oudemans) foram coletados em associação com C. pulcher (Gutierrez et al., 1989). Na Índia, o ácaro fitoseídeo Euseius vignus Rishi \& Rather foi observado alimentando-se de formas imaturas de $C$. pulcher em diversos hospedeiros (Rishi \& Rather, 1983).

\section{- status quarentenário}

C. pulcher é considerado uma praga de importância quarentenária para frutíferas decíduas na América do Norte (Kahan, 1989). Maçãs brasileiras têm sido importadas, em sua maior parte, pela Comunidade Européia, mas também pelo Canadá (Brasil, 1994). Desta forma, a simples introdução da espécie pode levar a restrições imediatas na importação de maçãs brasileiras pelo Canadá. 
O potencial de importância econômica de $C$. pulcher no Brasil é considerado médio, de acordo com as informações disponíveis sobre a espécie. Apesar da importância econômica de um de seus principais hospedeiros no Brasil - a maçã -, não se dispõe de informações sobre o impacto na produção da cultura e os trabalhos referindo-se à espécie como praga são antigos. Um fato importante a considerar é o status quarentenário da espécie em paíse importadores de frutos brasileiros. Entretanto, não há justificativas suficientes, no momento, para considerar a espécie como de grande importância econômica.

$\Rightarrow$ Potencial de Introdução - Médio

- possibilidades de infestação dos produtos importados nos países de origem

* presença e abundância da espécie nos países exportadores.

C. pulcher ocorre em alguns países exportadores de frutos potencialmente infestados para o Brasil. As principais vias de ingresso identificadas foram: maçãs da Inglaterra, Holanda, Hungria e Itália; mudas de macieiras da Holanda; pêras de Portugal e ameixas de Portugal e Holanda (Brasil, 1996).

C. pulcher não é uma espécie abundante em paises europeus, os quais são os exportadores de produtos potencialmente infestados para o Brasil. A espécie é considerada uma praga ocasional de maçã, pêra, ameixa e noz na Inglaterra, Dinamarca, Holanda, Portugal, Áustria, Bulgária, Alemanha e Itália (Jeppson et al., 1975).

\section{* volume, frequência e época das importações}

Apesar dos países exportadores de maçãs para o Brasil onde $C$. pulcher ocorre não serem os principais exportadores, pois Holanda, Hungria, Itália e Inglaterra são respectivamente os sétimo, oitavo, décimo primeiro e décimo segundo exportadores de maçãs para o Brasil, volumes relativamente significativos destes frutos têm sido importados, totalizando 292,19 $\mathrm{t}$ da Holanda, 248,08 $\mathrm{t}$ da Hungria, 88,73 t da Itália e 
38,81 t da Inglaterra no período de janeiro de 1992 a agosto de 1996 (Anexo B, Tabela 1) (Brasil, 1996).

Portugal e Holanda são, respectivamente, os sexto e décimo principais exportadores de ameixas para o Brasil, tendo exportado somente 19,88 t e 0,76 t destes frutos para o Brasil no período considerado (Anexo B, Tabela 8) (Brasil, 1996).

Volumes consideráveis de pêras têm sido importados de Portugal, totalizando $1.948,07$ t no período de janeiro de 1992 a agosto de 1996 , colocando este país como o terceiro principal exportador para o Brasil. A frequência das importações de pêras de Portugal tem sido relativamente alta, pois foram importados 27 lotes no período considerado (Anexo B, Tabela 2) (Brasil, 1996).

Não se dispõe de informações sobre a fenologia de $C$. pulcher na Europa para avaliar se as importações dos produtos potencialmente infestados têm sido realizadas em épocas de alto risco de infestação. As importações de pêras de Portugal têm sido realizadas durante a maior parte do ano, no período de julho a fevereiro (Anexo $\mathrm{C}$, Tabela 2) (Brasil, 1996). Provavelmente ocorre algum pico populacional de $C$. pulcher neste período, que corresponde ao verão/outono/inverno, elevando as possibilidades de infestação destes frutos.

Grandes quantidades de mudas de macieiras têm sido importadas da Holanda pelo Brasil, totalizando 336.835 unidades no período de janeiro de 1992 a agosto de 1996 (Brasil, 1996).

Considerando os parâmetros acima, existem possibilidades de infestação de produtos importados no país de origem, entretanto, estas não devem ser consideradas grandes, pois a espécie não é abundante nos paises exportadores de produtos potencialmente infestados.

- possibilidades de sobrevivência da espécie às condições de transporte dos materiais.

C. pulcher apresenta mecanismo de diapausa para sobreviver às condições adversas do inverno e é extremamente resistente a baixas temperaturas. As fêmeas 
hibernantes podem sobreviver a temperaturas de até $-30^{\circ} \mathrm{C}$ (Sepasgosarian, 1970). Isto indica que as fềmeas hibernantes ou aquelas prestes a hibernar associadas a frutos podem sobreviver às condições de transporte dos mesmos, normalmente realizado a baixas temperaturas e alta umidade relativa (Anexo E) (Brasil, 1994).

Ácaros da espécie porventura associados a mudas de macieiras apresentam grandes possibilidades de sobrevivência durante o transporte das mesmas.

Portanto, considera-se grande a possibilidade de sobrevivência dos ácaros às condições de tranporte dos produtos potencialmente infestados.

- possibilidades de deteç̧ão dos ácaros na ocasião da chegada de produtos infestados no Brasil.

\section{* localização na planta hospedeira}

Estes ácaros são relativamente sedentários e vivem em grupos na superficie inferior das folhas ao longo das nervuras. Podem alimentar-se também sobre o pecíolo folhar (Bayan, 1984; Meyer, 1979). Normalmente, os ovos são encontrados ao longo da nervura principal, escondidos entre os tricomas (Meyer, 1979). As fêmeas hibernantes permanecem em ranhuras do tronco do seu hospedeiro ou nas proximidades de gemas (Meyer, 1979; Zaher et al., 1973). Não se dispõe de informações sobre a localização dos ácaros em frutos.

Portanto, para a detecção de C. pulcher, especialmente de ovos e fềmeas hibernantes, é necessária uma detalhada inspeção do material, pois estas formas encontram-se em locais protegidos no hospedeiro.

\section{* dimensões/ coloração da espécie}

Como outros ácaros, as diversas formas de desenvolvimento de $C$. pulcher são bastante pequenas. Os ovos são vermelho-brilhantes, ovais e medem $110 \mu \mathrm{m}$ por $70 \mu \mathrm{m}$. As fềmeas medem cerca de $320 \mu \mathrm{m}$ de comprimento e $160 \mu \mathrm{m}$ de largura e apresentam intensa coloração escarlate. O macho é menor e mais pálido que a fềmea, seu abdomen é quase transparente (Jeppson et al., 1975). 
A coloração avermelhada de ovos de $C$. pulcher pode dificultar a detecção dos mesmos, quando associados a frutos de coloração semelhante, como maçãs ou ameixas. Entretanto, pode facilitá-la, quando associados a frutos de coloração verde, como pêras.

De uma maneira geral, a detecção destes ácaros é dificil devido às suas reduzidas dimensões, especialmente a de ovos.

* apresentação de sintomas em plantas/produtos infestados

Não se dispõe de informações sobre os sintomas causados pelas infestações de C. pulcher.

Consideram-se poucas as possibilidades de detecção de C. pulcher na ocasião da chegada de produtos infestados no Brasil, devido à sua localização de alguns estágios de desenvolvimento em locais protegidos nos hospedeiros, às suas reduzidas dimensões e à carência de técnicos adequadamente treinados para a detecção de ácaros em material vegetal no Brasil.

O potencial de introdução de $C$. pulcher no Brasil é considerado médio pois a espécie não é abundante nos países exportadores de produtos potencialmente infestados, apesar das dificuldades de sua detecção e grande possibilidade de sobrevivência às condições de transporte dos produtos.

\section{$\Rightarrow$ Potencial de estabelecimento - Médio}

\section{- disponibilidade de hospedeiros}

Entre os principais hospedeiros de $C$. pulcher, os cultivados em maiores extensões no Brasil são: maçã, em 27.318 ha; pêra, em 2.303 ha; noz, em 2.514 ha e marmelo, em 1.363 ha (Anuário Estatístico do Brasil, 1997).

As importações de produtos potencialmente infestados por C. pulcher têm sido destinadas a estados onde são cultivadas extensas áreas das principais espécies hospedeiras deste ácaro. 
As mudas de macieiras importadas da Holanda, maçãs importadas da Inglaterra e quase todas as importações de maçãs da Itália têm sido destinadas ao Rio Grande do Sul (Anexo D, Tabela 1). Este estado é principal produtor de maçãs, pêras e nozes (Anuário Estatístico do Brasil, 1997; Brasil, 1996).

Quase todas as importações de maçãs da Holanda $(99,9 \%)$ têm sido destinadas a Santa Catarina (Anexo D, Tabela 1), segundo principal produtor de maçãs (Anuário Estatístico do Brasil, 1997; Brasil, 1996).

As importações de pêras e ameixas de Portugal e de ameixas da Holanda têm sido destinadas a São Paulo (Anexo D, Tabelas 2 e 8), importante produtor de maçãs e pêras (Anuário Estatístico do Brasil, 1997; Brasil, 1996).

Portanto, há grande disponibilidade de hospedeiros para C. pulcher no Brasil, especialmente nas regiões para onde produtos potencialmente infestados têm sido destinados.

\section{- uso proposto}

Os ácaros que, porventura, estejam infestando as mudas de macieiras importadas apresentam alto potencial de estabelecimento.

- adequação das condições climáticas brasileiras para a sobrevivência, desenvolvimento e reprodução da espécie

Um maior número de gerações de $C$. pulcher ocorrem no Irã (3), Iraque (3) e Líbano (2), quando comparado ao de países europeus, onde desenvolve-se apenas 1 geração por ano (Bayan, 1984; Elmosa, 1971; Meyer, 1979; Sepasgosarian, 1970). Este ácaro é considerado uma praga mais séria em países do oriente médio e norte da África, como mencionado anteriormente. Isto indica que as condições climáticas de países destas regiões são mais favoráveis ao desenvolvimento da espécie que as européias.

As condições climáticas de países do Oriente Médio e norte da África são bastante distintas das brasileiras nas regiões de produção dos principais hospedeiros de C. pulcher, isto é, Sul e Sudeste. O clima de países do Oriente Médio e norte da África é predominantemente árido e semi-árido e das regiões Sul e Sudeste do Brasil úmido, 
durante praticamente todo o ano (Brasil, 1992; World Meteorological Organization, 1996).

O potencial de estabelecimento de $C$. pulcher no Brasil é considerado médio. Apesar da grande disponibilidade de hospedeiros para a espécie no país, as condições climáticas dos países onde a espécie se desenvolve melhor são marcadamente distintas daquelas do Brasil, onde seus principais hospedeiros são cultivados.

\subsubsection{Eotetranychus carpini (Oudemans, 1905) (Tetranychidae)}

- Sinônimos - Tetranychus carpini Oudemans, 1905; Tetranychus borealis Ewing, 1913; Eotetranychus carpini borealis (Ewing, 1913); Tetranychus flavus Ewing, 1913; Tetranychus oregonensis McGregor, 1917; Tetranychus monticolus McGregor, 1917; Schizotetranychus carpinula Reck, 1950; Schizotetranychus pterocaryae Reck, 1950 (Flechtmann ${ }^{19}$ ).

- Nomes vulgares - "Yellow spider mite"; E. carpini vitis - "Yellow vine mite"

- Distribuição geográfica - América do Norte (Canadá, EUAN); Ásia (China, Líbano, Turquia); Europa (Espanha, França, Inglaterra, Itália, Suiça) (Flechtmann ${ }^{19}$ ).

Hospedeiros - Betulaceae (Alnus sp., Carpinus betulus, C. orientalis, Corylus sp.); Ericaceae (Vaccinium sp.); Fagaceae (Fagus grandiflora, F. sylvatica); Hippocastanaceae (Aesculus sp.); Juglandaceae (Pterocarya fraxinifolia); Platanaceae (Platanus occidentalis); Rhamnaceae (Rhamnus sp.); Rosaceae (Malus domestica, Prunus avium, $P$. cerasus, $P$. domestica, $P$. sp., Pyrus sp., Rosa rugosa, $R$. sp., Rubus idaeus, R. sp. Spiraea sp.); Salicaceae (Salix caprea, S. sp.); Ulmaceae (Celtis

\footnotetext{
${ }^{19}$ FLECHTMANN, C. H. W. (Pesquisador CNPq, Depto. Zoologia, ESALQ, Universidade de São Paulo,
} Piracicaba, SP). Comunicação pessoal, 1997. 
occidentalis); Vitaceae (Vitis vinifera, V. sp.) (Flechtmann ${ }^{20}$; Villaronga \& Garcia Mari, 1992).

Características biológicas - Na Itália, verificou-se que a primeira geração leva cerca de 1 mês para seu desenvolvimento, e as subseqüentes de 15 a 18 dias (Laffi, 1982). O tempo total de desenvolvimento em laboratório, na França, diminuiu de 28,4 para 9,7 dias quando a temperatura aumentou de $15^{\circ} \mathrm{C}$ para $30,3^{\circ} \mathrm{C}$ (Bonato et al., 1990). As fêmeas desta espécie põem uma média de 30 a 40 ovos (Jeppson et al., 1975; Schruft, 1985). No norte da Itália observam-se de 7 a 8 gerações por ano e na Inglaterra, 6 gerações por ano (Jeppson et al., 1975; Laffi, 1982).

$\Rightarrow$ Potencial de importância econômica - Alto

- importância econômica e/ou social de seus hospedeiros no Brasil

São diversos os hospedeiros de E. carpini que apresentam importância econômica no país, podendo-se destacar maçã e uva, que são de grande importância econômica no país (ítem 3.4.1) (Anuário Estatístico do Brasil, 1997; Brasil, 1994). Além destas fruteiras, pêra e ameixa também apresentam alguma importância no Brasil. Uma outra cultura hospedeira de E. carpini que apresenta grande importância no pais é a de rosas, uma das flores mais cultivadas e apreciadas.

\section{- danos e perdas causadas devido às infestações pela espécie}

Infestações de E. carpini no início do desenvolvimento das videiras inibem o crecimento das brotações, enquanto que em um período posterior, evitam sua lignificação, induzem queda prematura de folhas e reduzem o conteúdo de açúcar dos frutos (Laffi, 1982). Severas infestações em pereiras e macieiras também podem causar danos (Barnes \& Madsen, 1961; Westigard \& Berry, 1970).

Não foram encontrados dados quantitativos sobre as perdas causadas por E. carpini, entretanto, diversos autores referem-se à espécie como uma importante praga.

${ }^{20}$ FLECHTMANN, C. H. W. (Pesquisador CNPq, Depto. Zoologia, ESALQ, Universidade de São Paulo, Piracicaba, SP). Comunicação pessoal, 1997. 
$\mathrm{Na}$ França, Espanha e Itália, E. carpini é um dos ácaros predominantes em videiras, juntamente com Tetranychus urticae Koch e Panonychus ulmi (Koch) (Arias Giralda et al., 1988;; Duso \& Liguori, 1984; Liguori, 1980; Schruft, 1985; Villaronga et al., 1991), sendo considerado uma das pragas mais importantes da cultura na região (Arias Giralda et al., 1988; Egger, 1996; Jeppson et al., 1975; Laffi, 1982). Também, tem causado danos a avelãs na Espanha (Villaronga \& Garcia Mari, 1992).

$\mathrm{Na}$ América do Norte, foi relatada a ocorrência da espécie atingindo níveis de praga em pomares de macieiras e pereiras no noroeste dos EUAN, especialmente em Oregon (Jeppson et al., 1975; Westigard \& Berry, 1970).

No Líbano, é uma das espécies de ácaros predominantes e de maior importância econômica em ameixa (Bayan, 1989).

\section{- medidas utilizadas para o controle da espécie}

Têm sido relatada a efetividade de ácaros e insetos predadores no controle de E. carpini na Europa. Na Itália, os predadores considerados mais eficientes são os fitoseídeos Typhlodromus pyri Scheuten, Kampimodromus aberrans (Oudemans), Phytoseius plumifer (Canestrini \& Fanzago), Amblyseius andersoni (Chant) e Typhlodromus exhilaratus Ragusa, além de antocorídeos e do coccinelídeo, Stethorus punctillum (Weise) (Castagnoli et al., 1989; Duso et al., 1993; Laffi, 1982; Schruft, 1985). Na Suiça, eficiente controle de populações da espécie foi observado pelos fitoseídeos $K$. aberrans e $T$. pyri (Baillod et al., 1982b). Os predadores considerados mais eficientes no controle de E. carpini não ocorrem no Brasil (Moraes, 1986).

Apesar do controle exercido sobre E. carpini pelos inimigos naturais, têm sido necessário também o controle químico. Os acaricidas que vêm controlando eficientemente a espécie são: piridabem, em videiras na França (Chichignoud \& Martin, 1991); cihexatina, em pereiras em Oregon, EUAN (Westigard et al., 1986); dicofol, protoato, tetradifom, fensom, clorfensom, benzoximato e propargite em videiras na Itália (Laffi, 1982).

Foi relatada a resistência de populações de $E$. carpini somente a organofosforados (Cranham \& Helle, 1985). 
Considera-se alto o potencial de importância econômica de $E$. carpini no Brasil devido à importância econômica de seu principais hospedeiros e, principalmente, devido à importância da espécie, que tem sido considerada uma das princiais pragas de videiras nos países do Mediterrâneo e alcança níveis de praga em pomares na América do Norte. Têm sido necessária a aplicação de pesticidas para o controle da espécie. O controle biológico também tem se mostrado bastante importante para evitar ou minimizar sérias infestações nos países onde E. carpini ocorre. Entretanto, os inimigos naturais relatados como eficientes para o controle da espécie não são assinalados no Brasil. Desta maneira, caso a praga seja introduzida no país, poderá atingir níveis populacionais mais elevados que nos países onde ocorre atualmente, pois estará livre da ação destes inimigos naturais.

\section{$\Rightarrow$ Potencial de Introdução - Alto}

\section{- possibilidades de infestação dos produtos importados nos países de origem}

* presença e abundância da espécie nos países exportadores.

E. carpini ocorre em vários países exportadores de material vegetal potencialmente infestado. As principais vias de ingresso da praga no Brasil são: mudas de videiras da Itália e França, pêras e maçãs dos EUAN e pêras da China (Anexo B, Tabelas 1,2 e 4) (Brasil, 1996).

Dentre os países exportadores mencionados acima, E. carpini é encontrado abundantemente na Itália, França e em algumas regiões dos EUAN (Bals, 1995; Egger, 1996).

* volume, frequência e época das importações

Mudas de videiras da França e Itália têm sido importadas em grandes volumes (Anexo B, Tabela 4) (Brasil, 1996).

As importações de mudas de videiras têm sido realizadas em setembro (Anexo C, Tabela 4), que corresponde a um dos meses de safra nos países do Mediterrâneo (Brasil, 
1994, Brasil, 1996). Na Itália, observou-se uma maior abundância da espécie no período final de crescimento das videiras (Lozzia et al., 1984). Certamente, no período de safra, as populações ainda são numerosas no campo. Deste modo, as importações de mudas de videiras da Itália e França têm sido realizadas em épocas de alto risco de infestação.

Os EUAN é o segundo principal exportador de maçãs e pêras para o Brasil. A frequência das importações têm sido alta; foram importados 49 lotes de maçãs e 80 lotes de pêras dos EUAN no período de janeiro de 1992 a agosto de 1996. As importações têm sido realizadas durante quase todo o ano (Anexo B, Tabelas 1 e 2; Anexo $\mathrm{C}$, Tabelas 1 e 2) (Brasil, 1996).

Portanto, são grandes as possibilidades de introdução de E. carpini no Brasil através da importação de maçãs e pêras dos EUAN e de mudas de videiras da Itália e França, considerando a abundância da espécie nestes países e o volume, frequência e época das importações.

- possibilidades de sobrevivência da espécie às condições de transporte dos materiais.

Durante o inverno, fềmeas fertilizadas permanecem em diapausa sob a casca solta das árvores ou na camada superficial do solo (Jeppson et al., 1975; Laffi, 1982), sobrevivendo a baixas temperaturas neste período. Isto indica que há possibilidades de que fềmeas em diapausa ou que iriam migrar para sítios de hibernação, porventura associadas a pêras ou maçãs, sobrevivam às condições de transporte dos mesmos, que é realizada a baixas temperaturas e alta umidade relativa (Anexo E) (Brasil, 1994).

Ácaros da espécie que estejam infestando mudas de videiras apresentam grandes possibilidades de sobrevivência às condições de transporte das mesmas.

Portanto, consideram-se altas as possibilidades de sobrevivência de E. carpini às condições de transporte dos produtos potencialmente infestados. 
- possibilidades de deteção dos ácaros na ocasião da chegada de produtos infestados no Brasil.

\section{* localização na planta hospedeira}

Colônias pequenas de E. carpini encontram-se na superficie inferior das folhas. A postura é realizada nesta região, nas proximidades da nervura principal e demais nervuras. Fêmeas hibernantes permanecem em locais protegidos em ranhuras ou sob a casca das plantas (Jeppson et al., 1975; Schruft, 1985). De uma maneira geral, os ácaros permanecem em locais de dificil visualização, sendo necessária uma detalhada inspeção para sua detecção. Um cuidado especial deve ser dispendido para a detecção de ovos e formas hibernantes.

\section{* dimensões/ coloração da espécie}

Os ovos de $E$. carpini são consideravelmente menores que os de $T$. urticae, medindo cerca de $100 \mu \mathrm{m}$, apresentando coloração verde-pálida. Os estágios imaturos também são verde-pálidos ou amarelo-esverdeados. Os adultos são muito pequenos e tênues, sendo que as fềmeas medem cerca de $318 \mu \mathrm{m}$ e os machos $200 \mu \mathrm{m}$ de comprimento; apresentam coloração amarela ou verde clara, com 2 ou 3 pares de pequenas manchas no corpo. As fêmeas hibernantes são amarelo-limão brilhantes (Baker \& Tuttle, 1994; Barnes \& Madsen, 1961; Jeppson et al., 1975).

Devido às pequenas dimensões destes ácaros e à discreta coloração da maior parte de seus estágios de desenvolvimento, considera-se dificil a detecção da espécie.

\section{* apresentação de sintomas em plantas/produtos infestados}

Ranhuras, manchas, descoloração ou áreas necróticas nas folhas podem indicar infestação por E. carpini (Jeppson et al., 1975; Laffi, 1982). Entretanto, alguns destes sintomas podem ser confundidos com outros problemas fitossanitários. Na América do Norte, a alimentação dos ácaros causa sintomas semelhantes a manchas de míldio (Jeppson et al., 1975). 
Normalmente, a presença de teia nas plantas pode indicar a infestação de ácaros, especialmente os da subfamília Tetranychinae, entretanto, E. carpini produz muito pouca teia (Jeppson et al., 1975).

São poucas as possibilidades de deteç̧ão de E. carpini em frutos ou mudas infestadas devido às suas reduzidas dimensões e coloração discreta da maioria dos estágios de desenvolvimento, por poderem encontrar-se em locais protegidos no hospedeiro e pela carência de técnicos adequadamente treinados para deteç̧ão de ácaros em material vegetal.

$\Rightarrow$ Potencial de estabelecimento - Alto

\section{- disponibilidade de hospedeiros}

Os hospedeiros de E. carpini encontrados no Brasil são: Vaccinium sp., em áreas alagadiças; algumas espécies do gênero Platamus, especialmente nos estados sulinos, utilizados em arborizações de ruas e parques; Salix, o vimeiro, representado no sul do Brasil por 2 espécies; as plantas ornamentais Rosa e Spiraea, flor-de-noiva; e as frutíferas maçã, uva, ameixa, pêra e amora.

Os hospedeiros de E. carpini cultivados em áreas mais extensas no Brasil são uva, em 60.396 ha; maçã, em 27.318 ha; pêra, em 2.303 ha e rosas, principalmente em São Paulo, Rio Grande do Sul e Minas Gerais (Anuário Estatístico do Brasil, 1997).

Os maiores volumes de importações de maçãs dos EUAN têm sido destinados a São Paulo, Santa Catarina e Paraná (Anexo D, Tabela 1), estados onde encontra-se a maior parte das áreas produtoras da cultura desta fruta (Anuário Estatístico do Brasil, 1997; Brasil, 1996).

Da mesma forma, os maiores volumes de pêras importadas dos EUAN são destinados à São Paulo e Paraná, e da China ao Paraná (Anexo D, Tabela 2). Estes estados são os principais produtores de pêras, uvas e maçã (Anuário Estatístico do Brasil, 1997; Brasil, 1996). 
Todos os lotes de mudas de videiras e macieiras importadas da Itália e França pelo Brasil têm sido destinados ao Rio Grande do Sul (Anexo D, Tabela 4), que é o principal produtor de uvas e de maçãs no Brasil (Anuário Estatístico do Brasil, 1997; Brasil, 1996).

Portanto, há grande disponibilidade de hospedeiros para E. carpini no Brasil, especialmente nas regiões para onde têm se destinado a maior parte das importações de produtos potencialmente infestados pela espécie.

\section{- uso proposto}

Ácaros da espécie que encontrem-se associados a mudas de videiras e macieiras importadas apresentam um alto potencial de estabelecimento.

\section{- potencial reprodutivo}

O período de desenvolvimento de E. carpini é relativamente curto. $\mathrm{Na}$ Itália, verificou-se que a primeira geração leva cerca de 1 mês para seu desenvolvimento, e as subseqüentes de 15 a 18 dias (Laffi, 1982).

Apesar da fecundidade das fềmeas de E. carpini não ser muito elevada, pois põem uma média de 30 a 40 ovos, a espécie desenvolve um grande número de gerações por ano, chegando a 7-8 gerações no norte da Itália (Jeppson et al., 1975; Laffi, 1982; Schruft, 1985).

Portanto, considera-se alto o potencial reprodutivo da espécie.

- adequação das condições climáticas brasileiras para a sobrevivência, desenvolvimento e reprodução da espécie

$\mathrm{Na}$ Itália e França observou-se que as populações de E. carpini são sensíveis ao calor e a chuvas fortes seguidas de calor intenso, que podem resultar em altas mortalidades, principalmente de ovos (Jeppson et al., 1975). Umidades abaixo de 30\% tem efeitos adversos no desenvolvimento da espécie, no Líbano (Bayan, 1989).

Nos estados brasileiros onde concentra-se a produção dos principais hospedeiros de E. carpini - São Paulo, Rio Grande do Sul, Paraná e Santa Catarina -, o clima é 
caracterizado como temperado úmido e calor e chuvas fortes seguidas de calor intenso podem ocorrer nos meses de verão. Entretanto, na maior parte do ano, as temperaturas são amenas a umidade relativa é alta (Brasil, 1992).

Portanto, em uma análise preliminar, pode-se considerar que as condições climáticas brasileiras são adequadas ao desenvolvimento de $E$. carpini.

O potencial de estabelecimento de E. carpini no Brasil é considerado alto devido à grande disponibilidade de seus hospedeiros no pais, à adequação das condições climáticas ao desenvolvimento da espécie, ao alto potencial reprodutivo e à prática da importação de mudas potencialmente infestadas.

\subsubsection{8 - Eotetranychus willamettei (McGregor, 1917) (Tetranychidae)}

- Sinônimo - Tetranychus willamettei McGregor, 1917

- Nome vulgar - "Willamette mite"

- Distribuição geográfica - América do Norte (EUAN) (Flechtmann ${ }^{21}$ )

- Hospedeiros - Aceraceae (Acer negundo), Fagaceae (Quercus garryana, Q. lobata), Polygonaceae (Eriogonum jamesii), Rosaceae (Ameliancher sp., Malus domestica, M. sp., Purshia tridentata; Pyrus communis, Sorbus domestica), Ulmaceae (Ulmus sp.), Vitaceae (Vitis vinifera) (Flechtmann ${ }^{21}$ ).

- Características biológicas - As larvas eclodem em 7 dias ou menos e o período ninfal total leva cerca de 10 dias (Jeppson et al., 1975).

${ }^{21}$ FLECHTMANN, C. H. W. (Pesquisador CNPq, Depto. Zoologia, ESALQ, Universidade de São Paulo, Piracicaba, SP). Comunicação pessoal, 1997. 
$\Rightarrow$ Potencial de importância econômica -Médio

- importância econômica e/ou social de seus hospedeiros no Brasil

Os hopedeiros de $E$. willamettei que apresentam importância econômica no Brasil são: uva e maçã, frutas de grande importância econômica no país (ítem 3.4.1) (Anuário Estatístico do Brasil, 1997; Brasil, 1994).

- danos e perdas causadas devido às infestações pela espécie

A alimentação sobre brotos em desenvolvimento pode impedir o crescimento e causar a deformação de folhas, encurtamento dos internódios e afinamento dos caules. Pode ocorrer uma diminuição no tamanho e qualidade dos frutos, desuniformidade e atraso na maturação dos mesmos (Jeppson et al., 1975).

As referências sobre a importância econômica da espécie são contraditórias. De acordo com Flaherty et al.(1969) e Schruft (1985), E. willamettei raramente causa danos econômicos em videiras nos EUAN e normalmente não há necessidade de tratamentos para seu controle, pois as videiras toleram altas populações deste ácaro, exceto em variedades de mesa. Entretanto, é considerada por Loeb English et al. (1986) e Jeppson et al. (1975) uma séria praga de videiras na Califórnia, juntamente com Tetranychus pacificus McGregor.

A população de E. willamettei não excedeu o limiar de dano econômico de 30 ácaros/folha em videiras em casa-de-vegetação na Califórnia (Karban et al., 1991).

Em avaliações sobre o efeito de infestações de $E$. willamettei em videiras Chenin Blanc e Zinfandel na Califórnia, não foram observados efeitos significativos na produção das variedades após a alimentação pelos ácaros. Entretanto, as infestações causaram uma redução significativa no conteúdo de açúcar de ambas variedades (McNally \& Farnham, 1985).

Infestação por $E$. willamettei reduziram o conteúdo de sólidos solúveis das uvas durante o primeiro ano de infestação. Após infestação por 2 anos, o peso total de frutos por videira foi reduzido em cerca de $18 \%$ a 1308 ácaros-dias; o tamanho médio das uvas 
foi reduzido em 8\% a 1308 ácaros-dias, enquanto não foram observadas reduções significativas no crescimento das brotações ou espessura do caule (Welter et al.,1989a).

Videiras Zinfandel que haviam apresentado alto nível de infestação por E. willamettei (1347 ácaros-dias) apresentaram uma redução de cerca de $15 \%$ na produção no primeiro ano após o início do controle. Entretanto, não foram observadas reduções significativas no crescimento vegetativo, tamanho médio das bagas ou número de cachos por planta. No segundo ano após o início do tratamento, não foi observada redução na produção (Welter et al., 1991).

\section{- efeito benéfico de $E$. willamettei em parreirais}

Diversos trabalhos têm relatado o efeito benéfico deste ácaro em parreirais, pois videiras que suportam populações de $E$. willamettei tendem a não ter ataques severos de T. pacificus, espécie que ocorre conjuntamente com $E$. willamettei economicamente mais importante nos EUAN.

$\mathrm{Na}$ Califórnia, E. willamettei foi útil em manter populações de Galendromus occidentalis (Nesbitt) no final da estação, quando T. pacificus não estava mais presente. Observou-se um equilibrio entre as populações de $T$. pacificus e seus predadores em parreirais onde as condições eram favoráveis para $E$. willamettei e ácaros da família Tydeidae, presas alternativas para G. occidentalis, e não foram realizadas pulverizações. Este equilíbrio não foi alcançado quando as presas alternativas não estavam presentes, quando então danos significativos foram causados à cultura (Flaherty et al.,1969 e 1972).

Loeb English \& Karban (1988) também constataram que a presença de E. willamettei teve um efeito negativo sobre populações de $T$. pacificus em casa-devegetação e no campo. Em alguns experimentos, o efeito negativo foi mais pronunciado quando as videiras haviam sido previamente danificadas por $E$. willamette $i$, em outros, a alimentação concomitante das duas espécies foi necessária para que o efeito negativo sobre $T$. pacificus ocorresse.

Os resultados de experimentos indicam que a causa da redução na população de $T$. pacificus não é a interferência fisica entre esta espécie e $E$. willamettei, mas sim a resistência induzida, que tem um efeito sistêmico (Hougen Eitzman \& Karban, 1995). 
- medidas utilizadas para o controle da espécie

Normalmente, não há necessidade de aplicação de tratamentos para o controle de E. willamettei em uva, seu principal hospedeiro, exceto em variedades de mesa (Schruft, 1985).

Não foram encontradas na literatura referências sobre desenvolvimento de resistência a pesticidas em populações de $E$. willamettei.

Na Califórnia, as populações de E. willamettei e $T$. pacificus geralmente são limitadas pelo fitoseídeo G. occidentalis, o predador mais abundante e o único cuja distribuição coincide com a de $E$. willamettei e $T$. pacificus sobre as folhagens. Outros predadores, principalmente das famílias Bdellidae e Anystidae, podem ser importantes em reduzir o número de ácaros sobreviventes ao período de hibernação nas fissuras dos troncos (Kinn \& Doutt, 1972a; Loeb English et al., 1986).

O potencial de importância econômica de $E$. willamettei é considerado médio. Apesar dos principais hospedeiros da espécie apresentarem importância econômica no Brasil, as informações sobre a severidade das infestações são variáveis. Alguns autores consideram que as infestações pela espécie não afetam a produção, enquanto que outros consideram-a uma praga importante, principalmente de variedades de uva de mesa. Estudos realizados sobre o efeito benéfico de infestações de $E$. willamettei para minimizar o efeito de infestações por T. pacificus em parreirais nos EUAN e o fato de não ser necessária a utilização de controle químico da espécie indicam que esta espécie não é de grande importância econômica para a cultura de uva neste país.

Apesar de não dispôr de dados para considerar E. willamettei uma espécie de importância econômica, mencionou-se acima que na Califórnia as populações da espécie são limitadas pelo ácaro fitoseídeo $G$. occidentalis. No Brasil este inimigo natural não é assinalado (Moraes, 1986). Portanto, caso a espécie seja introduzida no país, poderá causar problemas mais sérios que em sua região de origem. 
$\Rightarrow$ Potencial de Introdução - Alto

- possibilidades de infestação dos produtos importados nos países de origem

\section{* presença e abundância da espécie nos países exportadores.}

E. willamettei ocorre nos EUAN, sendo abundante na Califórnia (Jeppson et al., 1975; Loeb English et al., 1986; Schruft, 1985). Os produtos importados dos EUAN que podem estar infestados por $E$. willamettei são uvas e mudas de videiras, maçãs e pêras (Anexo B, Tabelas 1,2,3 e 4) (Brasil, 1996).

\section{* volume, frequência e época das importações}

O volume das importações de produtos potencialmente infestados por E. willamettei pelo Brasil têm sido bastante grande. Os EUAN têm sido o principal exportador de uvas e o segundo principal exportador de maçãs e pêras para o Brasil (Anexo B, Tabelas 1,2 e 3) (Brasil, 1996).

A frequência das importações de uvas, pêras e maçãs dos EUAN pelo Brasil têm sido altas, tendo sido importados 124, 80 e 49 lotes destas frutas, respectivamente, no período de janeiro de 1992 a agosto de 1996 (Anexo B, Tabelas 1,2 e 3) (Brasil, 1996).

Não se dispõe de informações detalhadas sobre a fenologia de $E$. willamettei nos EUAN para avaliar se as importações dos produtos potencialmente infestados têm sido realizadas em épocas de alto risco de infestação. Entretanto, as importações de maçãs, pêras e uvas deste país têm sido realizadas durante praticamente todo o ano (Anexo $\mathrm{C}$, Tabelas 1,2 e 3) (Brasil, 1996), sendo alto o risco de infestação destes frutos, quaisquer que sejam as épocas de ocorrência de picos populacionais da espécie.

Considerando os parâmetros acima, são altas as possibilidades de infestação de produtos importados no país de origem. 
- possibilidades de sobrevivência da espécie às condições de transporte dos produtos.

As fềmeas adultas entram em diapausa no inverno (Jeppson et al., 1975), sendo resistentes a baixas temperaturas neste periodo. É possivel que fềmeas hibernantes ou prestes a hibernar associadas a frutos sobrevivam às condições de transporte dos mesmos, que no caso de maçãs e uvas é realizado a baixas temperaturas e alta umidade relativa (Anexo E) (Brasil, 1994).

Ácaros da espécie porventura associados a mudas de videiras importadas apresentam altas possibilidades de sobreviverem às condições de transporte das mesmas.

Portanto, considera-se alta a possibilidade de sobrevivência dos ácaros às condições de tranporte dos produtos potencialmente infestados.

- possibilidades de detecção dos ácaros na ocasião da chegada de produtos infestados no Brasil.

\section{* localização na planta hospedeira}

Estes ácaros permanecem em colônias alimentando-se na superficie inferior das folhas de videiras. A oviposição é realizada em qualquer local da superficie inferior das folhas, sendo os ovos aderidos à epiderme, tricomas folhares ou às nervuras. As fềmeas hibernantes podem ser encontradas isoladas ou em grupos sob a casca das videiras,

principalmente na porção inferior destas (Jeppson et al., 1975). Portanto, é necessária uma detalhada inspeção para detecção destes ácaros, que podem estar em locais bem protegidos das plantas, tendo-se cuidado especial com ovos nas proximidades das nervuras e fềmeas hibernantes sob a casca das videiras.

Não foram encontradas informações sobre a localização dos ácaros quando infestando frutos.

\section{* dimensões/coloração da espécie}

Como outros ácaros, as diversas formas de desenvolvimento de $E$. willamettei são bastante pequenas. Os ovos são minúsculos, arredondados, transparentes e brilhantes. As 
fêmeas de verão apresentam coloração amarela-pálida ou marfim, enquanto que as hibernantes são âmbar a amarelas (Jeppson et al., 1975).

A visualização destes ácaros é dificultada por suas reduzidas dimensões e pela coloração discreta da maioria dos estágios de desenvolvimentodesta espécie. As fềmeas hibernantes que apresentam coloração mais forte, sendo mais facilmente visualizadas, normalmente encontram-se em locais protegidos nas plantas.

\section{* apresentação de sintomas em plantas/produtos infestados}

As folhas infestadas por E. willamettei passam a apresentar aparência mosqueada, com manchas amareladas, quando as colônias são pequenas $\mathrm{e}$, por folhagem de coloração palha, quando a densidade dos ácaros é alta (Jeppson et al., 1975; Schruft, 1985).

A presença de teia sobre as plantas pode sinalizar infestação por $E$. willamettei, apesar de não a produzirem abundantemente (Schruft, 1985).

Consideram-se poucas as possibilidades de detecção de $E$. willamettei na ocasião da chegada de produtos infestados no Brasil devido às suas reduzidas dimensões; coloração discreta da maioria dos estágios de desenvolvimento da espécie; à localização nos hospedeiros, que pode ser em locais de difficil visualização e à carência de técnicos adequadamente treinados para a detecção de ácaros em material vegetal no Brasil.

\section{$\Rightarrow$ Potencial de estabelecimento - Alto}

\section{- disponibilidade de hospedeiros}

Os hospedeiros de E. willamettei cultivados em áreas mais extensas no Brasil são: maçã, em 27.318 ha e uva, em 60.396 ha. As importações de produtos potencialmente infestados por E. willamettei têm sido destinadas a estados onde são cultivadas extensas áreas destes hospedeiros.

As mudas de videiras importadas dos EUAN têm sido destinadas ao Rio Grande do Sul $(83,3 \%)$ e Bahia (16,7\%) (Anexo D, Tabela 4). No Brasil, o Rio Grande do Sul é principal produtor de uvas e de maçãs. A Bahia, juntamente com Pernambuco, são os 
principais produtores de uva irrigada no Brasil. (Anuário Estatístico do Brasil, 1997; Brasil, 1996).

A quase totalidade das importações de uvas $(98,7 \%)$ e a maior parte das de maçãs $(61,7 \%)$ e pêras $(83,7 \%)$ dos EUAN têm sido destinadas a São Paulo (Anexo D, Tabelas 3,2 e 1). Este estado é o segundo principal produtor de uvas e importante produtor de maçãs no Brasil (Anuário Estatístico do Brasil, 1997; Brasil, 1996).

Cerca de $20 \%$ das importações de pêras dos EUAN têm sido destinadas a Santa Catarina (Anexo D, Tabela 2), segundo principal produtor de maçãs e importante produtor de uvas (3.985 ha) no país (Anuário Estatístico do Brasil, 1997; Brasil, 1996).

Portanto, há grande disponibilidade de hospedeiros para E. willamettei no Brasil, especialmente nos estados para onde produtos potencialmente infestados têm sido destinados.

\section{- uso proposto}

Os ácaros que, porventura, estejam infestando mudas de videiras apresentam um alto potencial de estabelecimento no país.

- adequação das condições climáticas brasileiras para a sobrevivência, desenvolvimento e reprodução da espécie

A distribuição geográfica de E. willamettei é restrita aos EUAN, sendo encontrado principalmente na Califórnia, onde predominam baixas umidades relativas, baixa pluviosidade e, durante o verão, as temperaturas são elevadas (World Meteorological Organization, 1996). No Brasil, condições climáticas semelhantes em regiões onde hospedeiros de $E$. willamettei são cultivados encontram-se em Pernambuco e Bahia, onde a cultura da uva é irrigada (Brasil, 1992). Em uma análise preliminar, caso E. willamettei seja introduzido no Brasil, poderá encontrar condições climáticas favoráveis ao seu desenvolvimento nestes estados.

Portanto, considera-se alto o potencial de estabelecimento de E. willamettei no Brasil devido à disponibilidade de hospedeiros no país, ao uso proposto de produtos 
potencialmente infestados e às condições climáticas favoráveis ao desenvolvimento da espécie em ao menos uma região brasileira produtora de uva - seu principal hospedeiro.

\subsubsection{9 - Oligonychus vitis Zaher \& Shehata, 1965 (Tetranychidae)}

- Distribuição geográfica - África (Egito), América do Norte (EUAN), América do Sul (Chile), Ásia (Índia) (Flechtmann ${ }^{22}$ ).

- Hospedeiros - Myrtaceae (Eucalyptus sp., Heteropyxis natalensis), Rosaceae (Pyracantha sp.), Vitaceae (Vitis vinifera) (Flechtmann ${ }^{22}$ ).

$\Rightarrow$ Potencial de importância econômica - Baixo

- importância econômica e/ou social de seus hospedeiros no Brasil

O principal hospedeiro de $O$. vitis e que apresenta importância econômica no Brasil é a uva, fruta de grande importância econômica no país (ítem 3.4.1) (Anuário Estatístico do Brasil, 1997; Brasil, 1994).

- danos e perdas causadas devido às infestações pela espécie

Não se dispõe de informações sobre danos e perdas causadas por infestações de O. vitis.

No Egito, algumas citações referem-se a esta espécie como sendo predominante sobre folhas e estacas de videiras, ou como importante praga desta cultura em algumas regiões do país (Rizk et al., 1978ab). Entretanto, de acordo com Yousef (1970), O. vitis não é abundante, quando comparado a outros ácaros.

Encontrou-se uma única referência sobre $O$. vitis no Chile, na qual Gonzalez (1983) o considera uma das pragas introduzidas nociva a videiras.

${ }^{22}$ FLECHTMANN, C. H. W. (Pesquisador CNPq, Depto. Zoologia, ESALQ, Universidade de São Paulo, Piracicaba, SP). Comunicação pessoal, 1997. 
- medidas utilizadas para o controle da espécie

Foram poucos os trabalhos encontrados relacionados ao controle de $O$. vitis.

No Egito, os compostos mais efetivos em ensaios visando ao controle de $O$. vitis e Tenuipalpus granati Sayed foram dicofol, clorobenzilato e uma mistura de tetradifom e dimetoato. Os ácaros Agistemus exsertus Gonzalez, Euseius gossipi (El Badry) e Tydeus californicus (Banks) foram observados predando O. vitis naquele país (Rizk et al., 1978b).

O potencial de importância econômica de $O$. vitis é considerado baixo pois encontraram-se poucas referências considerando a espécie como praga, estas são relativamente antigas e não relatam os danos ou perdas causadas.

\subsubsection{0. - Panonychus ulmi (Koch, 1836) (Tetranychidae)}

- Sinônimos - Tetranychus ulmi Koch, 1836; Oligonychus ulmi (Koch, 1836); Metatetranychus ulmi (Koch, 1836); Paratetranychus ulmi (Koch, 1836); Tetranychus pilosus Canestrini \& Fanzago, 1876; Paratetranychus pilosus (Canestrini \& Fanzago, 1876); Tetranychus alboguttatus Zacher, 1913; Metatetranychus alboguttatus (Zacher); Paratetranychus pilosus occidentalis McGregor \& Newcomer, 1928; Oligonychus alni Oudemans, 1929; Metatetranychus alni (Oudemans, 1929); Oligonychus muscorum Oudemans, 1929; Metatetranychus muscorum (Oudemans, 1929); Oligonychus potentillae Oudemans, 1929; Metatetranychus potentillae (Oudemans, 1929); Metatetranychus mali Oudemans, 1931; Metatetranychus canestrinii Oudemans, 1939 $\left(\right.$ Flechtmann ${ }^{23}$ ).

- Nomes vulgares - "European red spider mite", "Fruit tree red spider mite"

${ }^{23}$ FLECHTMANN, C. H. W. (Pesquisador CNPq, Depto. Zoologia, ESALQ, Universidade de São Paulo, Piracicaba, SP). Comunicação pessoal, 1997. 
- Distribuição geográfica - África (África do Sul, Argélia, Egito, Marrocos, Líbia, Tunísia), América Central (Costa Rica), América do Norte (Bermuda, Canadá, EUAN), América do Sul (Argentina, Brasil, Chile, Uruguai, Venezuela), Ásia (Afeganistão, China, Coréia, Índia, Irã, Israel, Japão, Líbano, Síria, Taiwan, Turquia, Vietnan), Europa (Alemanha, Áustria, Bélgica, Bulgária, CIS, Dinamarca, Espanha, Finlândia, França, Grécia, Hungria, Ilha Madeira, Irlanda, Itália, Iugoslávia, Lituânia, Noruega, Países Baixos, Polônia, Portugal, Reino Unido, Romênia, Suécia, Suiça, Tchecoslováquia), Oceania (Austrália, Nova Zelândia, Tasmânia) (Flechtmann ${ }^{24}$ )

- Hospedeiros - Amaranthaceae (Amaranthus sp.), Apiaceae (Daucus carota), Betulaceae (Alnus glutinosa, A. incana, A. sp., Betula pubescens, $B$. sp., B. verrucosa, Corylus avellana), Caprifoliaceae (Lonicera japonica, Symphoricarpos foetidus), Chenopodiaceae (Chenopodium sp.), Convolvulaceae (Calystegia sepium, Convolvulus arvensis), Curcubitaceae (Cucumis sp., Curcubita maxima, C. pepo), Ebenaceae (Diospyros sp.), Fabaceae (Medicago sativa, Phaseolus sp., Trifolium pratense, Trifolium sp., Vicia sativa), Fagaceae (Castanea sativa, Fagus sylvatica, Quercus sp.), Gramineae (Avena sativa, Sorghum halepense, Triticum aestivum, Zea mays), Grossulariaceae (Ribes aureum, $R$. sanguineum, Ribes sp.), Hippocastanaceae (Aesculus hippocastamum), Juglandaceae (Juglans regia), Juncaceae (Juncus maritimus), Leguminosae (Acacia longifolia, Dalbergia sisso, Desmodium canescens, Laburnum alpinum, Robinia pseudoacacia, Wisteria sinensis), Malvaceae (Hibiscus sp., Malva sp.), Moraceae (Ficus carica, Artocarpus heterophyllus, Morus nigra, M. sp.), Myricaceae (Myrica pensylvanica), Myrtaceae (Syzygium sp.), Oleaceae (Fraxinus excelsior, F. sp.), Polemoniaceae (Phlox sp.), Polygonaceae (Polygonum aviculare, Rumex obtusifolius), Rhamnaceae (Rhamnus alnus, R. frangula, R. sp.), Rosaceae (Amelanchier sp., Cotoneaster tomentosus, Crataegus monogyna, C. sp., C. succulenta, Cydonia oblonga, Eriobotrya japonica, Fragaria sp., F. vesca, Malus domestica, M. sp., Potentilla fruticosa, Prumus americana, P. armeniaca, P. avium, P. cerasus, P. chinensis,

\footnotetext{
${ }^{24}$ FLECHTMANN, C. H. W. (Pesquisador CNPq, Depto. Zoologia, ESALQ, Universidade de São Paulo, Piracicaba, SP). Comunicação pessoal, 1997.
} 
$P$. divaricata, $P$. domestica, $P$. dulcis, $P$. insititia, $P$. padus, $P$. persica, $P$. sp., P. spinosa, Pyracantha sp., Pyrus baccata, P. communis, $P$. pyrifolia, $P$. sargentii, $P$. sp., Rosa canina, R. multiflora, R. palustris, R. sp., Rubus idaeus, R. occidentalis, $R$. sp., Sorbus aria, S. aucuparia, S. chrysophylla, S. conradina, S. fennica, S. hostii, S. scandica), Rubiaceae (Gardenia jasminoides), Rutaceae (Citrus aurantiifolia, C. aurantium, C. grandis), Salicaceae (Populus sp., P. tremula, Salix alba), Sapindaceae (Sapindus saponaria), Saxifragaceae (Hydrangea macrophylla), Solanaceae (Atropa belladonna), Theaceae (Camellia sinensis), Tiliaceae (Tilia cordata), Ulmaceae (Ulmus americana, U. campestris, U. glabra, U. hollandica, U. procera, U. rubra, U. scabra, U. sp.), Umbelliferae (Petroselinum hortense), Vitaceae (Vitis labrusca, V. sp., V. vinifera) (Flechtmann ${ }^{25}$ ).

- Características biológicas - Para $P$. ulmi completar uma geração são necessárias de 3 a 6 semanas, dependendo das temperaturas. $O$ número de gerações por ano varia de acordo com o local; na Holanda podem-se desenvolver de 3-5 gerações, enquanto que em Virginia, EUAN normalmente são encontradas de 9-10 gerações (Van de Vrie, 1985a). Durante seu ciclo de vida, as fềmeas podem depositar de 10 a 90 ovos, sendo a média de 45 (Jeppson et al., 1975). No Brasil, o número de ovos por fềmea foi de 45 e 51 (Kovaleski \& Vendramim, 1993).

\section{- Situação de $P$. ulmi no Brasil}

Este encontra-se atualmente nas regiões produtoras de maçã do Sul do Brasil e constitui uma das principais pragas da cultura no país (Kovaleski \& Vendramim, 1993), sendo necessária a aplicação de medidas de controle para a espécie.

O controle biológico deste ácaro no Brasil tem-se mostrado viável em pomares onde adota-se o monitoramento e o manejo integrado de pragas (Lorenzato \& Secchi, 1993), entretanto, o controle químico também é necessário e comumente empregado. São muitos os acaricidas registrados para o controle de $P$. ulmi em maçã no Brasil (Andrei, 1996). O desenvolvimento de resistência a acaricidas por populações de $P$. ulmi no Brasil

\footnotetext{
${ }^{25}$ FLECHTMANN, C. H. W. (Pesquisador CNPq, Depto. Zoologia, ESALQ, Universidade de São Paulo, Piracicaba, SP). Comunicação pessoal, 1997.
} 
praticamente não tem sido relatado, com exceção do trabalho de Humeres et al (1995), que constatou a ocorrência de resistência de populações de $P$. ulmi a clofentezine em pomares de macieiras nas regiões de São Joaquim, Santa Catarina e Vacaria, Rio Grande do Sul.

É bastante importante evitar a introdução de novos biótipos desta praga no Brasil, que podem vir a agravar os problemas que já vem sendo causados pela espécie na cultura da maçã ou mesmo causar problemas em outras culturas.

$\Rightarrow$ Potencial de importância econômica - Alto

- importância econômica e/ou social de seus hospedeiros no Brasil

P. ulmi é uma espécie polífaga, que apresenta um grande espectro de hospedeiros, infestando cerca de 130 espécies vegetais $\left(\right.$ Flechtmann $^{26}$ ). As culturas às quais $P$. ulmi causa maiores problemas em outros países são frutíferas de folhas decíduas, principalmente maçã, pêra, ameixa, marmelo, pêssego e videiras (Jeppson et al., 1975; Van de Vrie, 1985a; Schruft, 1985; Soenen et al., 1977). Dentre os hospedeiros de P. ulmi, os que apresentam maior importância econômica no Brasil são uva e maçã (item 3.4.1). O pêssego e a pêra também são frutíferas importantes no Brasil (Anuário Estatístico do Brasil, 1997; Brasil, 1994).

- danos e perdas causadas devido às infestações pela espécie

$P$. ulmi é uma espécie de grande importância econômica, sendo considerada uma das quatro espécies de tetraniquídeos mais importantes (Rabbinge, 1985). É considerado o ácaro-praga mais importante em frutíferas decíduas nos EUAN, Europa, Canadá, Nova Zelândia, Tasmânia, Japão, Argentina e Chile (Costa Comelles et al., 1994; Gonzalez, 1984; Herbert, 1981; Lienk et al., 1980; Monetti \& Fernández, 1995; Soenen et al., 1977; Van de Vrie, 1985a). Esta espécie também é uma séria praga de videiras na Europa, Canadá e leste dos EUAN (Schruft, 1985).

\footnotetext{
${ }^{26}$ FLECHTMANN, C. H. W. (Pesquisador CNPq, Depto. Zoologia, ESALQ, Universidade de São Paulo, Piracicaba, SP). Comunicação pessoal, 1997.
} 
Em maçã, as infestações causam redução na produção de frutos durante o ano da infestação e no ano seguinte a esta, devido à redução no número de flores e no crescimento das árvores, principalmente das brotações (Beers \& Hull, 1990; Hoyt \& Tanigoshi, $1983^{27}$ in Van de Vrie, 1985a; Zwick et al., 1976).

A redução na produção de maçãs causada por infestações de $P$. ulmi se deve principalmente à redução no peso dos frutos, como observado em Israel, em Golden Delicious; em Oregon e Washington, EUAN e em Crimea, Ucrânia (Beers \& Hull, 1990; Bulgak, 1979; Palevsky et al., 1996; Zwick et al., 1976). Observou-se também uma alteração na coloração e firmeza dos frutos (Zwick et al., 1976).

As infestações de $P$. ulmi em videiras também afetam o desenvolvimento de brotos e inflorescências e a qualidade dos frutos (Schruft, 1985).

São poucas as informações disponiveis sobre as perdas quantitativas causados por infestações de $P$. ulmi. Em macieiras, populações de 100 ou mais ácaros/folha levaram a perdas de 40 a $65 \%$ da produção na Ucrânia (Bulgak, 1979).

\section{- medidas utilizadas para o controle da espécie}

Para o controle de $P$. ulmi têm-se utilizado métodos químicos e biológicos. Também vêm sendo realizados trabalhos na área de resistência de plantas.

Várias espécies de ácaros predadores fitoseídeos, além de insetos predadores foram observadas predando P. ulmi em videiras e macieiras (Hoy, 1985; Lorenzato \& Secchi, 1993; Schruft, 1985). Entretanto, são poucas as espécies de importância para o controle biológico.

Liberações artificiais do fitoseídeo predador Typhlodromus pyri Scheuten para o controle de $P$. ulmi em parreirais têm tido sucesso, mas estes ácaros não são capazes de controlar a praga em todos os cultivos, sendo às vezes necessária a aplicação de acaricidas (Schruft, 1985).

Em pomares de macieiras, também vêm sendo realizadas liberações de ácaros predadores para o controle de $P$. ulmi. Em Oregon, EUAN, observou-se que liberações

${ }^{27}$ HOYT, S. C.; TANIGOSHI, L. K. Economic injury levels for apple insect and mite pests. In: CROFT, B. A; HOYT, S. C. (Ed.) Integrated management of insect pests of pome and stone fruit. New Yor: John Wiley \& Sons, 1983. p. 203-217. 
de Galendromus occidentalis (Nesbitt) e T. pyri apresentam aspectos complementares que permitem o controle de $P$. ulmi e $A$. schlechtendali conjuntamente (Croft \& Mac Rae, 1992). Em alguns países europeus, como Holanda, Suiça e Itália, bons resultados têm sido obtidos em pomares em que foram utilizados acaricidas seletivos e liberações de T. pyri, algumas vezes resistentes a alguns pesticidas (Baillod et al., 1982b; Wertheim, 1990).

O controle biológico de $P$. ulmi é viável em pomares de maçã onde se utiliza o manejo integrado de pragas. Em Cataluña, Espanha, em pomar onde utilizavam-se somente inseticidas seletivos aos inimigos naturais, $P$. ulmi manteve-se controlado biologicamente, sendo que o fitoseídeo Amblyseius andersoni (Chant) foi o predador mais eficiente. $\mathrm{O}$ mesmo ocorreu no Reino Unido, onde $T$. pyri tornou-se suficientemente abundante, mantendo as populações de $P$. ulmi abaixo do nível de dano econômico (Easterbrook et al., 1985). No Brasil, em pomares onde o controle químico não foi utilizado, o controle biológico de $P$. ulmi e Tetranychus urticae Koch mostrou-se tecnicamente viável (Lorenzato \& Secchi, 1993).

Alguns trabalhos têm sido realizados comparando a susceptibilidade de variedades de macieiras às infestações por $P$. ulmi. Em Israel, a cultivar Golden Delicious foi mais sensivel à infestação pelo ácaro que Oregon Spur (Palevsky et al., 1996). Na Califórnia, EUAN, as variedades Standard, Red Delicious, Golden Delicious, Rome Beauty e Jonathan foram mais susceptiveis às infestações pelo ácaro, enquanto que, Gravensteins e Yellow Newtons foram menos danificadas (Barnes \& Madsen, 1961). No Brasil, não se observou diferença no ciclo de desenvolvimento de $P$. ulmi entre as cultivares Gala e Golden Delicious, embora Golden Delicious tenha sido mais adequada para os adultos que Gala (Ribeiro et al., 1988). Em Washington, EUAN, Beers \& Hull (1987) compararam o efeito de infestações de $P$. ulmi sobre 3 variedades de maçã (Golden Delicious, Satayman e Delicious) e, de uma maneira geral, Delicious pareceu ser mais tolerante aos danos que as demais variedades.

Apesar da importância do controle biológico, a aplicação de pesticidas também é necessária para o controle de $P$. ulmi. 
Os acaricidas que vêm apresentando maior eficiência para o controle de $P$. ulmi são: hexitiazox, clofentezine, flucicloxurom, amitraz, bifentrina; cihexatina, dicofol, propargite, azociclotina, óxido de fenbutatinaa, bromopropilato e cihexatina + benzoximato (Aveyard, 1988; Kuijpers \& Zwaan, 1992; Park et al., 1986; Pollak \& Drinkall, 1990; Rathman et al., 1990; Vogt et al., 1990). Muitas vezes, pulverizações com óleo antes da eclosão das larvas dos ovos em diapausa são efetivas e dão melhores resultados que tratamentos após a brotação, quando as larvas já eclodiram (Baillod et al., 1982a; Reis Filho \& Petri, 1992; Soenen et al., 1977).

Entretanto, em vários países estão ocorrendo problemas no controle químico de $P$. ulmi devido ao desenvolvimento de resistência a pesticidas por populações da espécie.

- riscos de introdução de biótipos distintos de $P$. ulmi no Brasil

- biótipos resistentes a pesticidas

A ocorrência de biótipos de $P$. ulmi resistentes a pesticidas é relatada em países onde P. ulmi já ocorria, causava problemas de ordem econômica e era controlado quimicamente, mesmo antes da espécie ser introduzida no Brasil, ou em paises onde utilizava-se intensivamente o controle químico para combater outras pragas de frutíferas.

Já se mencionava em 1961 na Califórnia que os programas de controle de P. ulmi em macieiras vinham sendo complicados devido à resistência desta espécie a organofosforados e outros acaricidas (Barnes \& Madsen, 1961). Também na Inglaterra, Cranham $(1975,1982 \mathrm{a}$ e b) relataram alta resistência de $P$. ulmi a dimetoato (inseticida acaricida organofosforado), binapacril (fungicida com ação acaricida) e tetradifom (acaricida específico).

Altos níveis de resistência a outros inseticidas-acaricidas organofosforados foram relatados. Em Nova York, EUAN, populações de $P$. ulmi apresentaram indícios de um alto grau de tolerância a carbofenotiom e etiom (Lienk, 1970). Na Tchecoslováquia, os niveis de resistência a tiometom variaram de 10 a 103 vezes e a fenitrotiom de 8 a 68 vezes (Hurkova et al., 1983). 
$\mathrm{Na}$ cultura da uva, a aplicação de um largo espectro de organofosforados para o controle das principais pragas da videira causou o desenvolvimento de um alto grau de resistência a estes produtos, que hoje são inefetivos para o controle de $P$. ulmi (Schruft, 1985).

Após se verificar a resistência de populações de $P$. ulmi a organofosforados, resistência a pesticidas de diversos grupos químicos tem sido relatada em diversas regiões.

Durante as décadas de 1960 e 1970, populações de $P$. ulmi em países europeus tornaram-se resistentes a vários compostos, como ometoato, dimetoato e alguns acaricidas (Sterk \& Highwood, $1992^{28}$ citado por Sterk, 1994).

Atualmente, há dificuldades em vários países europeus em controlar P. ulmi com os acaricidas ovolarvicidas hexitiazox e clofentezine (Sterk \& Highwood, $1992^{18}$ citado por Sterk, 1994).

Na Pensilvânia, EUAN e Austrália ocorrem populações de $P$. ulmi resistentes a organotin. Em laboratórios, estas populações mostraram altos níveis de resistência a hexitiazox e clofentezine, sugerindo a ocorrência de resistência cruzada aos produtos (Rathman et al., 1990).

$\mathrm{Na}$ Itália, resultados de testes em laboratório confirmaram a suspeita de que populações de $P$. ulmi em pomares de macieira estariam apresentando alto nível de resistência a clofentezine (Angeli et al., 1994).

Resistência ao acaricida organoestânico cihexatina foi relatada em vários países. Na Nova Zelândia, foram relatados problemas no controle de $P$. ulmi com este produto, tendo sido confirmada em laboratório a ocorrência de populações resistentes a níveis de 6,3 a 21,9 vezes em relação às populações susceptíveis (Chapman et al., 1987). Em Virginia, EUAN, observou-se uma reduzida efetividade de cihexatina no controle no controle de $P$. ulmi em macieiras, resultante de uma diminuição na susceptibilidade ao composto (Pfeiffer \& Pfeiffer, 1986). Após 5 anos de tratamentos com cihexatina para o

${ }^{28}$ STERK, G.; HIGHWOOD, D. P. Implemention of IRAC anti-resistance guidelines with IPM programmes for Belgian apple and pear orchards. In: BRITISH CROP PROTECTION CONFERENCE, PESTS AND DISEASES, Brighton, 1992. Proceedings. 1992. p.517-526. 
controle de $P$. ulmi no Canadá e Iugoslávia, as populações canadenses permaneceram homogeneamente susceptíveis, enquanto que algumas populações iugoslavas desenvolveram resistência ao produto (Stamenkovic et al., 1985).

Resistência ao acaricida organoclorado dicofol por populações de $P$. ulmi que infestavam macieiras foi relatada em Suweon, Coréia, em um nível de 5,7 vezes, quando comparada a populações susceptíveis (Park et al., 1986).

Em uma revisão realizada por Cranham \& Helle (1985) sobre desenvolvimento de resistência a acaricidas em tetraniquídeos, constatou-se que existem fortes evidências de que $P$. ulmi apresenta resistência múltipla a dez grupos de acaricidas: fensom, tetradifom, dicofol, binapacril, organofosforados, carbamatos, quinometionato, clordimeform, propargite e cihexatina.

A introdução de biótipos de $P$. ulmi resistentes a pesticidas comumente utilizados e eficientes no Brasil para o controle da espécie pode levar a um aumento nas dosagens ou no número de tratamentos necessários, aumentando os custos de produção da cultura e causando maiores prejuízos ambientes.

- biótipos de $P$. ulmi que infestam videiras

As opiniões de pesquisadores quanto à possibilidade de que ácaros desta espécie que infestam videiras representem um biótipo distinto daquele que infesta macieiras são contraditórias. De acordo com B. Gotz (1956) ${ }^{29}$ citado por Schruft (1985), é evidente que as formas de $P$. ulmi que se alimentam em videiras representam um biótipo específico pois não se obtém sucesso quando são transferidos natural ou artificialmente para outras culturas. Diferentemente, segundo Vrabl (1974), as populações de $P$. ulmi sobre videiras não são biótipos distintos daquelas de macieiras, já que não existem diferenças morfológicas e os ácaros não apenas sobrevivem e se reproduzem quando tranferidos de uma planta a outra, mas também migram espontâneamente.

No Brasil, somente têm sido relatadas infestações de $P$. ulmi em macieiras.

${ }^{29}$ B. Götz, 1956 - comunicação pessoal 
É conveniente, portanto, evitar que sejam introduzidos biótipos específicos de videiras ou que ataquem videiras e macieiras, pois este ácaro têm causado sérios problemas em parreirais em outros países.

Considerando os ítens acima, o potencial de biótipos de $P$. ulmi em causar ou agravar problemas em culturas de importância econômica no Brasil é elevado.

\section{$\Rightarrow$ Potencial de Introdução - Alto}

- possibilidades de infestação dos produtos importados nos países de origem

* presença e abundância da espécie nos países exportadores.

As principais vias de ingresso de biótipos distintos de $P$. ulmi no Brasil, considerando as referências encontradas sobre populações resistentes a pesticidas ou infestações de videiras nos diferentes países, são: maçãs dos EUAN, França, Nova Zelândia, Holanda, Hungria, Espanha, Canadá, Itália e Inglaterra; mudas de macieiras da Holanda; uvas dos EUAN e Holanda e mudas de videiras dos EUAN e Alemanha (Brasil, 1996).

De uma maneira geral, $P$. ulmi é bastante abundante em países exportadores de produtos potencialmente infestados para o Brasil, sendo a espécie mais comum em pomares de frutíferas decíduas da América do Norte e Europa (Lienk et al., 1980; Soenen et al., 1977). Em macieiras, é particularmente abundante no norte da Europa, nordeste dos EUAN e leste do Canadá. Na Nova Zelândia, também é a espécie mais comum (Van de Vrie, 1985a). P. ulmi é considerado um dos principais artrópodos-praga em frutíferas na Itália e em macieiras em Portugal (Janela, 1996; Oberhofer \& Graffin, 1982). Em videiras, P. ulmi é uma importante praga no norte da Europa, Canadá e leste dos EUAN (Schruft, 1985).

* volume, frequência e época das importações

$O$ volume das importações de produtos potencialmente infestados por novos biótipos de $P$. ulmi pelo Brasil é bastante grande. 
Biótipos distintos de $P$. ulmi podem ser introduzidos através da importação de maçãs de 9 dentre os 14 países que têm exportado estes frutos para o Brasil. EUAN, França e Nova Zelândia são, respectivamente, o segundo, quarto e quinto principais exportadores de maçãs para o Brasil (Anexo B, Tabela 1) (Brasil, 1996).

O volume das importações de uvas também têm sido bastante grande, sendo a quarta fruta mais importada de janeiro de 1992 a agosto de 1996 (Tabela 3). Os EUAN têm sido o principal exportador de uvas para o Brasil (Anexo B, Tabela 3) (Brasil, 1996).

Grandes quantidades de mudas de macieiras e videiras têm sido importadas. A Holanda têm sido o único país a exportar mudas de macieiras para o Brasil, tendo exportado um total de 336.835 mudas no período considerado. Um grande número de mudas de videiras também têm sido importadas dos EUAN e Alemanha (Anexo B, Tabela 4) (Brasil, 1996).

As importações de maçãs e uvas dos EUAN têm sido bastante freqüentes. Foram importados 49 lotes de maçãs e 124 lotes de uvas deste país pelo Brasil no período considerado (Anexo B, Tabelas 1 e 3) (Brasil, 1996).

As importações de maçãs e uvas dos EUAN têm sido realizadas durante praticamente todo o ano (Anexo B, Tabelas 1 e 3) (Brasil, 1996), sendo alto o risco de infestação destes frutos, quaisquer que sejam as épocas de ocorrência de picos populacionais da espécie.

Considerando os ítens acima, são muitas as possibilidades de infestação por biótipos distintos de $P$. ulmi de produtos importados, devido à abundância da espécie nos países onde ocorrem e aos grandes volumes e alta freqüência das importações de produtos potencialmente infestados.

\section{- possibilidades de sobrevivência da espécie às condições de transporte dos materiais.}

Estes ácaros passam o inverno no estágio de ovo, em diapausa (Van de Vrie, 1985a), sendo bastante resistentes a baixas temperaturas neste periodo. É possível, portanto, que ovos em diapausa porventura associados a frutos de maçãs sobrevivam às 
condições de transporte dos mesmos, que é realizado a baixas temperaturas e alta umidade relativa (Anexo E) (Brasil, 1994).

Ácaros desta espécie que estejam infestando mudas de videiras ou macieiras apresentam grandes possibilidades de sobrevivência às condições de transporte das mesmas.

Considera-se, portanto, alta a possibilidade de sobrevivência dos ácaros às condições de tranporte dos produtos potencialmente infestados.

- possibilidades de detecção dos ácaros na ocasião da chegada de produtos infestados no Brasil.

\section{* localização na planta hospedeira}

Estes ácaros não se agregam em colônias bem-definidas, encontrando-se dispersos em ambas superficies folhares. As formas imaturas alimentam-se principalmente na superficie inferior das folhas, mas os adultos alimentam-se em ambas superficies, especialmente quando as infestações são intensas. Ovos não diapáusicos são depositados principalmente na superficie inferior das folhas. Ovos em diapausa são depositados em grupos em áreas rugosas na base das gemas, em fendas e pontos que marcam o início de novas brotações (Jeppson et al., 1975; Van de Vrie, 1985a). Ovos também podem ser encontrados em frutos de maçã, no cálice e pedúnculo (Flechtmann, 1967; Lienk et al., 1980). As larvas recém-eclodidas buscam brotações novas (Jeppson et al., 1975).

Desta forma, para a detecção de $P$. ulmi em mudas ou frutos, especialmente a de ovos, é necessária uma detalhada inspeção.

\section{* dimensões/ coloração da espécie}

Os ovos de $P$. ulmi medem $147 \mu \mathrm{m}$ de diâmetro (Lienk et al., 1980). Os ovos de verão aparentemente variam de coloração, dependendo do local e do estágio de desenvolvimento, podendo ser verde-pálidos, verde-escuros, marrom-avermelhados, laranja-escuros ou vermelho-brilhantes. Os ovos hibernantes são vermelhos. As larvas recém-eclodidas são de coloração alaranjada-pálida, tornando-se em seguida marrom- 
avermelhadas, com a margem anterior pálida. As protoninfas também variam de coloração, mas mostram as primeiras evidências de manchas pálidas na base das setas, que se tornam mais distintas na deutoninfa. A fêmea adulta recém-emergida é verde escura aveludada, marrom aveludada ou verde amarronzada. Posteriormente, a coloração muda para vermelho amarronzado e apresentam manchas brancas nas bases das setas dorsais (Jeppson et al., 1975). As fêmeas medem cerca de $329 \mu \mathrm{m}$ e os machos $313 \mu \mathrm{m}$ de comprimento (Baker \& Tuttle, 1994).

A maioria dos estágios de desenvolvimento de $P$. ulmi apresenta coloração viva, o que pode facilitar ou dificultar sua visualização, dependendo da coloração do substrato. Ovos diapáusicos de coloração vermelha podem passar desapercebidos em frutos de maçã. Algumas formas apresentam coloração discreta, como ovos não-diapáusicos e fêmeas recém-emergidas, podendo passar desapercebidos em uma inspeção superficial, especialmente em mudas. Como ocorre com os outros ácaros, a deteç̧ão da espécie é dificultada por suas pequenas dimensões.

* apresentação de sintomas em plantas/produtos infestados

As infestações de $P$. ulmi causam descoloração e bronzeamento folhar, freqüentemente seguido por queda das folhas (Jeppson et al., 1975; Van de Vrie, 1985a).

A presença de teia sobre as plantas pode sinalizar infestação por $P$. ulmi, apesar de estes ácaros normalmente produzirem pouca teia (Van de Vrie, 1985a).

Consideram-se poucas as possibilidades de detecção de $P$. ulmi na ocasião da chegada de produtos infestados no Brasil devido às suas reduzidas dimensões; à localização nos hospedeiros, que pode ser em locais de dificil visualização e à carência de técnicos adequadamente treinados para a deteç̧ão de ácaros em material vegetal no Brasil.

- disseminação de $P$. ulmi através de material em trânsito.

P. ulmi é uma espécie originária da Europa (Lienk et al., 1980), que atualmente encontra-se distribuida por todas as áreas de cultivo de maçã e outras frutíferas no mundo 
(Jeppson et al., 1975; Van de Vrie, 1985a). Isto se deve, em muito, à presença de ovos em diapausa em material comercial. No Brasil, Flechtmann (1967) detectou um grande número de ovos de P. ulmi em um lote de maçãs importadas da Argentina em uma casa comercial de Piracicaba - São Paulo e cogita-se a hipótese de que tenha sido introduzido no país desta maneira. Aparentemente, esta espécie foi introduzida nos EUAN através de material comercial e, agora, encontra-se amplamente distribuido na América do Norte (Lienk et al., 1980).

Mudas ou material para propagação de frutiferas também podem veicular formas viáveis de P. ulmi. Ácaros desta espécie foram interceptados pelo "Yokohama Plant Protection Station", no Japão, em mudas de ameixa importadas da Alemanha (Masaki, 1991). No Irã, o ácaro vermelho europeu foi introduzido através de estacas de maçã infestadas provenientes da França e Suiça em 1971 (Bayatassadi \& Parsi, 1980).

Para evitar a disseminação de $P$. ulmi através da comercialização de frutos, têm sido estabelecidos tratamentos para eliminação dos ovos associados a estes. No Canadá, ovos em diapausa de $P$. ulmi e formas dormentes de $T$. mcdanieli em frutos de maçã foram mortos por dibrometo de etileno a uma dosagem de $6 \mathrm{mg} / 1$ por 4 horas a $24^{\circ} \mathrm{C}$. Não ocorreu injúria nos frutos e o sabor não foi alterado (Bond et al., 1973). Também, a utilização de atmosferas com $90 \%$ de dióxido de carbono por $72 \mathrm{~h}$ a $18^{\circ} \mathrm{C}$ ou por $48 \mathrm{~h}$ a $25^{\circ} \mathrm{C}$ matou todos os ovos; $75 \%$ de dióxido de carbono por $60-168$ horas matou cerca de $98 \%$ dos ovos (Herne \& Bond, 1981).

Apesar da espécie encontrar-se amplamente distribuida no mundo, é considerada uma praga de importância quarentenária para alguns países ou regiões (Holdeman, $1986^{30}$ citado por Kahan, 1989). São tomados cuidados para evitar sua introdução em regiões onde ainda não ocorre. Por exemplo, na Austrália $P$. ulmi está presente em New South Wales e Queensland, no leste da Austrália, mas não no oeste do país e, por isto, são adotadas restrições de produtos de áreas onde a espécie ocorre para áreas onde não ocorre (Schagen ${ }^{31}$ ).

${ }^{30}$ HOLDEMAN, Q. (Ed) Plant pests of phytosanitary significance to importing countries and states. 5.ed. Sacramento: California Department of Food and Agriculture, 1986.

${ }^{31}$ SCHAGEN, J. V. (Área de Quarentena, Agriculture Western Australia) Comunicação pessoal, 1997. 
Portanto, o potencial de introdução de biótipos distintos de $P$. ulmi no Brasil é alto, devido às grandes possibilidades de infestação dos produtos importados nos países onde ocorrem, às possibilidades de sobrevivência dos ácaros às condições de transporte dos produtos potencialmente infestados e às poucas possibilidades de detecção dos ácaros na ocasião da introdução dos produtos infestados.

$\Rightarrow$ Potencial de estabelecimento - O potencial de estabelecimento de $P$. ulmi no Brasil não será avaliado devido à espécie já ocorrer no país.

\subsubsection{1 - Tetranychus canadensis (McGregor, 1950) (Tetranychidae)}

- Sinônimo - Septanychus canadensis (McGregor, 1950)

- Distribuição geográfica - América do Norte (Canadá, EUAN), Europa (Hungria, Polônia) (Flechtmann ${ }^{32}$ ).

- Hospedeiros - Anacardiaceae (Rhus hirtellum), Asclepiadaceae (Asclepias sp.), Bromeliaceae (Cryptonthus angustifolia), Caprifoliaceae (Diervilla sp., Viburnum opulus), Chenopodiaceae (Atriplex canescens, A. polycarpa, A. semibaccata), Convolvulaceae (Ipomoea batatas), Fabaceae (Gymnocladus canadensis, Phaseolus sp., Trifolium pratense), Fagaceae (Fagus grandiflora), Hammamelidaceae (Hamamelis virginiana), Hippocastanaceae (Aesculus hippocastanum), Juglandaceae (Carya cordiformis), Liliaceae (Polygonatum biflorum), Magnoliaceae (Magnolia sp.), Malvaceae (Abelmoschus esculentus, Althaea rosea, Gossypium hirsutum), Meliaceae (Azadirachta indica, Melia sp.), Moraceae (Maclura pomifera, M. sp.), Oleaceae (Fraxinus pensylvanica, F. velutina, F. sp.), Poaceae (Echinochloa colona, Hordeum vulgare, Secale cereale, Triticum aestivum, Zea mays), Rosaceae (Malus domestica, M. sp., Potentilla hippiana, Prunus americana, P. domestica, P. sp., P. virginiana,

${ }^{32}$ FLECHTMANN, C. H. W. (Pesquisador CNPq, Depto. Zoologia, ESALQ, Universidade de São Paulo, Piracicaba, SP). Comunicação pessoal, 1997. 
Pyrus baccata, Rosa multiflora, R. sp.), Salicaceae (Populus sp.), Solanaceae (Lycopersicum esculentum), Ulmaceae (Ulmus americana, U. laevis, U. rubra, U. sp.) (Flechtmann ${ }^{33}$ ).

$\Rightarrow$ Potencial de importância econômica - Baixo

- importância econômica e/ou social de seus hospedeiros no Brasil

São diversos os hospedeiros de $T$. canadensis que apresentam importância econômica no Brasil, destacando-se trigo, feijão, algodão, milho, laranja, maçã, pêssego, rosas e hortícolas, incluindo tomate. No Brasil, dentre estes hospedeiros, milho, feijão, trigo e algodão são culturas extensivas de grande importância econômica. As frutíferas hospedeiras de $T$. canadensis também são bastante importantes no Brasil. Laranja é a principal e maçã a sexta principal fruta no país, em valor de produção. Tomate é cultivado em áreas extensas por todo o país (Anuário Estatístico do Brasil, 1997; Brasil, 1994).

\section{- danos e perdas causadas devido às infestações pela espécie}

Não se dispõe de dados sobre perdas quantitativas causadas por $T$. canadensis. A única referência considerando este ácaro como uma praga é a de Jeppson et al. (1975), que o considera uma praga de diversas culturas, plantas ornamentais e árvores, causando problemas principalmente a pêssego, ameixa, maçã, tomate, feijão, batata-doce, quiabo, algodão, trevo, cevada, centeio, milho, trigo, ornamentais, rosas e laranja.

\section{- medidas utilizadas para o controle da espécie}

Não foram encontradas referências sobre medidas utilizadas para o controle de T. canadensis. Sabe-se, entretanto, que populações desta espécie apresentam resistência a organofosforados (Cranham \& Helle, 1985).

\footnotetext{
${ }^{33}$ FLECHTMANN, C. H. W. (Pesquisador CNPq, Depto. Zoologia, ESALQ, Universidade de São Paulo, Piracicaba, SP). Comunicação pessoal, 1997.
} 
O potencial de importância econômica de Tetramychus canadensis é considerado baixo. Encontrou-se apenas uma referência considerando a espécie como praga, relativamente antiga, sem relatar os danos ou perdas causadas. A ausência de trabalhos sobre medidas de controle também é um indicativo da não importância da espécie.

\subsubsection{2 - Tetranychus mcdanieli McGregor, 1931 (Tetranychidae)}

- Nome vulgar - "McDaniel spider mite"

- Distribuição geográfica - América do Norte (Canadá, EUAN) e Europa (França) $\left(\right.$ Flechtmann $^{34}$ ).

- Hospedeiros - Aceraceae (Acer saccharum), Caprifoliaceae (Lonicera japonica), Fabaceae (Thermopsis pinetorum), Grossulariaceae (Ribes sp.), Moraceae (Morus sp.), Poaceae (Phleum pratense), Ranunculaceae (Thalictrum fendleri), Rosaceae (Fragaria virginiana, Malus domestica, Prunus americana, P. avium, P. persica, Rubus idaeus), Ulmaceae (Ulmus americana), Vitaceae (Vitis vinifera) (Flechtmann ${ }^{34}$ )

- Características biológicas - O tempo de desenvolvimento de uma geração de T. mcdanieli a $40-65 \%$ de umidade relativa a $18,21,24,27,29,32$ e $35^{\circ} \mathrm{C}$ foram, respectivamente $31,21,18,15,14$ e 10 dias; a fecundidade total de fềmeas nestas mesmas condições foi de 51, 88, 126, 119, 157, 183 e 134 ovos (Tanigoshi et al., 1975). O número de gerações por ano varia de 7 a 9 nos EUAN e Canadá, dependendo das condições de temperatura (Jeppson et al., 1975).

\footnotetext{
${ }^{34}$ FLECHTMANN, C. H. W. (Pesquisador CNPq, Depto. Zoologia, ESALQ, Universidade de São Paulo, Piracicaba, SP). Comunicação pessoal, 1997.
} 


\section{$\Rightarrow$ Potencial de importância econômica - Alto}

- importância econômica e/ou social de seus hospedeiros no Brasil

São diversos os hospedeiros de $T$. mcdanieli que apresentam importância econômica no Brasil, destacando-se maçã, uva e pêssego. As cultura às quais T. mcdanieli vêm causando danos mais sérios em outros países são maçã e uva (Anuário Estatístico do Brasil, 1997; Brasil, 1994).

\section{- danos e perdas causadas devido às infestações pela espécie}

Nos EUAN, observou-se descoloração e diminuição do crescimento dos frutos de macieiras Red Delicious devido à infestação por T. mcdanieli. Uma redução significativa no crescimento dos frutos ocorreu quando as infestações excederam 2.000 ácaros-dia (Tanigoshi \& Browne, 1981).

$\mathrm{Na}$ França, infestações no início do desenvolvimento de videiras causaram descoloração e necrose difusa sobre os órgãos das plantas jovens. No verão, grandes manchas vermelhas foram relatadas sobre as folhas (Rambier, 1982).

Não se dispõe de dados sobre perdas quantitativas causadas por T. mcdanieli, mas a espécie tem sido considerada uma séria praga de frutíferas decíduas, principalmente no centro e oeste dos EUAN e no Canadá, e especificamente de videiras, na França (Haley et al., 1990; Jeppson et al., 1975; Lienk et al., 1980; Rambier, 1982; Tanigoshi et al., 1975).

\section{- medidas utilizadas para o controle da espécie}

Além do controle químico de $T$. mcdanieli, o controle biológico tem sido utilizado com sucesso em algumas situações.

Nos EUAN, uma maior eficiência no controle de $T$. mcdanieli foi obtida utilizando-se cihexatina juntamente com cloreto de cálcio (Tanigoshi \& Babcock, 1990). $\mathrm{Na}$ França, entre os acaricidas testados para o controle de T. mcdanieli, o mais eficiente foi Acafor (dicofol + etiom) (Rambier, 1982). 
Algumas dificuldades foram apontadas quanto ao controle químico de T. mcdanieli. Os tratamentos durante o inverno não são efetivos pois os ácaros hibernam em locais protegidos. Durante o verão, a abundante formação de teia pelos ácaros dificulta a cobertura das aplicações (Jeppson et al., 1975).

O desenvolvimento de resistência a pesticidas por populações de $T$. mcdanieli também tem comprometido a eficiência de tratamentos químicos. A primeira observação de resistência da espécie foi feita em Washington, EUAN a acaricidas organofosforados em 1950 (Tanigoshi et al., 1975). Atualmente, há fortes evidências de resistência múltipla da espécie a acaricidas, tendo sido relatada resistência a fensom, tetradifom, binapacril e organofosforados (Cranham \& Helle, 1985).

$\mathrm{O}$ controle biológico tem se mostrado efetivo principalmente em pomares onde se utiliza o manejo integrado de pragas, ou quando liberam-se predadores resistentes a pesticidas. Em um pomar de maçã no Canadá onde o manejo integrado de pragas havia sido adotado por 4 anos, a população de T. mcdanieli manteve-se abaixo do nível de dano econômico pela ação do ácaro fitoseídeo Galendromus occidentalis (Nesbitt) (Madsen \& Carty, 1977). Em Champagne, França, os danos causador por T. mcdanieli em videiras foram reduzidos após liberações de ácaros fitoseídeos Typhlodromus pyri Scheuten (Blaise \& Louvet, 1992). Biótipos de G. occidentalis resistentes a alguns pesticidas têm controlado populações de $T$. mcdanieli em pomares de maçã e ameixa nos EUAN (Anthon \& Smith, 1975; Hoy et al., 1983).

\section{- status quarentenário}

T. mcdanieli é uma praga de importância quarentenária para a África do Sul (Barnes, 1975). Na Austrália, a espécie também não ocorre e são empregadas medidas para evitar sua introdução $\left(\right.$ Schagen $\left.^{35}\right)$.

O potencial de importância econômica de T. mcdanieli no Brasil é elevado devido à importância econômica de seus hospedeiros no país; por ser considerada uma séria praga de frutíferas decíduas; devido à necessidade de aplicação de pesticidas para seu

\footnotetext{
${ }^{35}$ SCHAGEN, J. V. (Área de Quarentena, Agriculture Western Australia) Comunicação pessoal, 1997.
} 
controle e à apresentação de resistência múltipla a acaricidas por populações da espécie e ao seu status quarentenário em países onde ainda não ocorre. Os inimigos naturais considerados eficientes para controlar a espécie não ocorrem no Brasil. Isto indica que a espécie pode vir a causar danos mais sérios aqui que nos países onde ocorre atualmente.

$\Rightarrow$ Potencial de Introdução - Alto

- possibilidades de infestação dos produtos importados nos países de origem

* presença e abundância da espécie nos países exportadores.

T. mcdanieli ocorre em países exportadores de produtos potencialmente infestados. As principais vias de ingresso identificadas foram: maçãs e pêras dos EUAN e Canadá; mudas de videiras da França e EUAN; pêssegos, framboesas, amoras, cerejas, uvas e ameixas dos EUAN (Brasil, 1996).

T. mcdanieli é uma espécie abundante nos países exportadores de produtos potencialmente infestados, especialmente no norte e oeste dos EUAN, em Washington, Oregon, Colorado e Califórnia; no sul do Canadá e na França, principalmente em Champagne (Barnes \& Madsen, 1961; Haley et al., 1990; Jeppson et al., 1975; Lienk et al., 1980; Tanigoshi \& Babcock, 1990;.

* volume, frequência e época das importações

O volume das importações de produtos potencialmente infestados por T. mcdanieli pelo Brasil é bastante grande. Os EUAN têm sido o segundo principal exportador de maçãs, pêras, cerejas, framboesas e pêssegos e o principal exportador de ameixas e uvas para o Brasil (Anexo B, Tabelas 1,2,7,9,6,8 e 3). Um grande número de mudas de videiras têm sido importadas da França e EUAN (Anexo B, Tabela 4) (Brasil, 1996).

As importações de maçãs, pêras, uvas, pêssegos, ameixas, cerejas e framboesas dos EUAN têm sido bastante freqüentes, tendo sido importados $49,80,124,214,182$, 
84 e 24 lotes, respectivamente, no período de janeiro de 1992 a agosto de 1996 (Anexo B, Tabelas 1,2,3,6,8,7 e 9) (Brasil, 1996).

As importações de pêras e maçãs têm sido realizadas durante quase todo o ano, sendo que as de maçãs concentraram-se em janeiro e fevereiro e as de pêras em agosto, dezembro e janeiro (Anexo $\mathrm{C}$, Tabelas 1 e 2). As importações de pêssegos dos EUAN têm sido realizadas no período de abril a outubro, sendo mais freqüentes de junho a agosto, e as de ameixas no período de maio a outubro, concentrando-se também de junho a agosto (Anexo $\mathrm{C}$, Tabelas 7 e 8). As importações de cerejas dos EUAN têm sido realizadas no período de abril a agosto e em novembro, concentrando-se de junho a agosto e as de framboesas no período de maio a agosto e em outubro e novembro, sendo mais freqüentes em junho e agosto (Anexo $\mathrm{C}$, Tabelas 6 e 9). As importações de uvas dos EUAN têm sido realizadas no periodo de junho a dezembro e em fevereiro e março, concentrando-se em agosto (Anexo C, Tabela 3) (Brasil, 1996).

Nos EUAN, as infestações por T. mcdanieli tornam-se severas no final de julho e agosto (Barnes \& Madsen, 1961; Jeppson et al., 1975), portanto, estes são considerados os meses de maior risco de infestação de produtos.

Desta maneira, a maior parte das importações de pêras, pêssegos, ameixas, uvas, cerejas e framboesas têm sido realizadas em épocas de alto risco de infestação pela espécie.

São muitas as possibilidades de infestação de produtos importados por T. macdanieli devido à abundância da espécie nos países exportadores e aos grandes volumes e alta freqüência das importações de produtos potencialmente infestados, que, em grande parte, têm sido realizadas em épocas de alto risco de infestação.

\section{- possibilidades de sobrevivência da espécie às condições de transporte dos materiais.}

As fềmeas adultas entram em diapausa no inverno (Jeppson et al., 1975), sendo resistentes a baixas temperaturas neste periodo. Muitas vezes, frutos colhidos encontramse infestados por fềmeas de T. mcdanieli hibernantes ou prestes a hibernar (Barnes \& Madsen, 1961; Bond et al., 1973). Estas fềmeas apresentam alta resistência a baixas 
temperaturas e podem sobreviver às condições de resfriamento em que os frutos são transportados (Anexo E) (Brasil, 1994). Para eliminação destes ácaros dos frutos, é necessária a realização de tratamentos quarentenários (Barnes, 1975; Bond et al., 1973).

Ácaros desta espécie porventura associados a mudas de videiras apresentam grandes possibilidades de sobrevivência às condições de transporte das mesmas.

Considera-se, portanto, alta a possibilidade de sobrevivência de $T$. mcdanieli às condições de transporte dos produtos potencialmente infestados.

- possibilidades de deteç̧ão dos ácaros na ocasião da chegada de produtos infestados no Brasil.

\section{* localização na planta hospedeira/ produtos infestados}

No início das infestações os ácaros alimentam-se preferencialmente na superficie inferior das folhas e, posteriormente, infestam ambas superficies (Jeppson et al., 1975). Os ovos são postos principalmente na superficie inferior das folhas (University of California, 1991). Frutos podem estar infestados por um grande número de fềmeas que permanecem na região do final do cálice (Barnes \& Madsen, 1961). As fềmeas hibernantes encontram-se sob a casca das plantas, logo abaixo do nível do solo, e na matéria orgânica na base das plantas (Barnes \& Madsen, 1961; Jeppson et al., 1975).

Portanto, para a deteç̧ão de T. mcdanieli em frutos ou mudas, especialmente a de ovos e fềmeas hibernantes, deve-se proceder uma detalhada inspeção.

\section{* dimensões/ coloração da espécie}

Como outras espécies de ácaros, T. macdanieli é pequeno. Os ovos são esféricos e medem cerca de $130 \mu \mathrm{m}$ de diâmetro, os machos tem cerca de $302 \mu \mathrm{m}$ e as fềmeas $382 \mu \mathrm{m}$ de comprimento (Baker \& Tuttle, 1994; Nielsen, 1958).

Os ovos de $T$. mcdanieli são claros de coloração palha. As fềmeas adultas são esverdeadas ou amareladas e podem apresentar uma única ou duas manchas escuras na extremidade final do corpo. As fềmeas hibernantes são alaranjadas-brilhantes (Barnes \& Madsen, 1961). Portanto, T. mcdanieli apresenta colorações discretas, com exceção das 
fềmeas hibernantes que, normalmente, permanecem em locais protegidos, o que dificulta a visualização destes ácaros.

\section{* apresentação de sintomas em plantas/produtos infestados}

As folhas infestadas por $T$. mcdanieli apresentam enrolamento de bordas, pontuações e bronzeamento (Jeppson et al., 1975).

Frutos severamente infestados apresentam a região do final do cálice coberta por fina teia, de modo que parecem estar forrados com papel celofane (Barnes \& Madsen, 1961).

A presença de teia sobre as plantas pode sinalizar infestação por $T$. mcdanieli, pois estes tecem-a abundantemente (Jeppson et al., 1975).

Consideram-se poucas as possibilidades de detecção de $T$. mcdanieli na ocasião da chegada de produtos infestados ao Brasil devido às suas reduzidas dimensões e coloração discreta da maioria dos estágios de desenvolvimento, por poderem estar em locais protegidos nos hospedeiros e pela carência de técnicos adequadamente treinados para detecção de ácaros em material vegetal no país.

\section{- introdução acidental de $T$. mcdanieli}

O primeiro registro da presença de T. mcdanieli na França foi realizado em 1982, em Champagne, onde estes ácaros estavam infestando e causando sérios danos em videiras. Dentre as várias hipóteses levantadas quanto à ocorrência da espécie naquele país, a mais aceita é a de introdução acidental. Cogitou-se a possibilidade de introdução do ácaro juntamente com lotes de ácaros predadores resistentes a pesticidas, que eram transportados juntamente com ácaros fitófagos dos quais se alimentam e, muitas vezes, liberados nas culturas junto com as presas (Rambier, 1982). 


\section{$\Rightarrow$ Potencial de estabelecimento - Alto}

\section{- disponibilidade de hospedeiros}

São diversos os hospedeiros de T. mcdanieli encontrados no Brasil, como: madressilva, amora, ameixa, maçã, pêra, pêssego, framboesa e uva.

Os hospedeiros de T. mcdanieli cultivados em áreas mais extensas no Brasil são: maçã, em 27.318 ha; pêra, em 2.303 ha; pêssego, em 20.188 ha e uva, em 60.396 ha (Anuário Estatístico do Brasil, 1997).

Como pode-se observar nas Tabelas 1 e 2 (Anexo D), a maior parte das maçãs e pêras importadas dos EUAN de janeiro de 1992 a agosto de 1996 foram destinadas a São Paulo, Santa Catarina e Paraná e todas as importações de pêras dos EUAN têm sido destinadas a São Paulo; estes estados são importantes produtores destas frutíferas. Santa Catarina é o estado onde encontram-se áreas mais extensas de cultivos de maçãs (Anuário Estatístico do Brasil, 1997; Brasil, 1996).

Da mesma maneira, a maior parte das importações de uvas e pêssegos dos EUAN foram destinadas a São Paulo, onde encontram-se extensas áreas cultivadas destas frutíferas, sendo o segundo principal produtor de uva e o terceiro principal produtor de pêssego no país (Anexo D, Tabelas 3 e 7) (Anuário Estatístico do Brasil, 1997; Brasil, 1996).

As mudas de videiras importadas dos EUAN têm sido destinadas ao Rio Grande do Sul $(83,3 \%)$ e à Bahia $(16,7 \%)$ e todas as importações da França para o Rio Grande do Sul (Anexo D, Tabela 4) (Brasil, 1996). Ambos estados produzem uva, sendo que o Rio Grande do Sul é o principal produtor brasileiro. O Rio Grande do Sul atualmente também é o principal produtor de maçãs (Anuário Estatístico do Brasil, 1997).

Portanto, há grande disponibilidade de hospedeiros de T. mcdanieli no Brasil, especialmente nas regiões para onde os produtos potencialmente infestados pela espécie têm sido destinados. 
- uso proposto

Os ácaros que, porventura, estejam infestando mudas de videiras apresentam um alto potencial de estabelecimento.

- adequação das condições clímáticas brasileiras para a sobrevivência, desenvolvimento e reprodução da espécie

As informações encontradas sobre as condições climáticas favoráveis ao desenvolvimento de $T$. mcdanieli são contraditórias. Alguns autores consideram que a espécie aumenta rapidamente e causa danos mais severos em climas quentes e secos (Barnes \& Madsen, 1961; Jeppson et al., 1975), enquanto que outra citação informa que a espécie se reproduz melhor em locais mais altos e frios (University of California, 1991).

Em estudos sobre a biologia de $T$. mcdanieli, observou-se que a temperatura ótima de desenvolvimento da espécie é de 29 a $32^{\circ} \mathrm{C}$ (Nielsen, 1958).

As condições climáticas mais favoráveis ao desenvolvimento de $T$. mcdanieli, considerando as informações sobre importância da praga nas áreas onde a espécie ocorre, são aquelas de Champagne, França; Washington, Oregon e Califórnia nos EUAN e de British Columbia no Canadá.

As condições climáticas nos estados brasileiros onde concentra-se a produção de maçãs e uvas (São Paulo, Santa Catarina, Paraná, Rio Grande do Sul), assemelham-se com as de Champagne, França (World Meteorological Organization, 1996).

É interessante notar que as condições climáticas do oeste dos EUAN, provavelmente região de origem de $T$. mcdanieli, em uma análise geral, não são semelhantes às condições de Champagne, França, onde este ácaro foi introduzido e se estabeleceu. No oeste dos EUAN, o clima é mais seco que o do norte da França.

Em uma análise preliminar, as condições climáticas brasileiras nos estados onde concentra-se a produção dos hospedeiros de $T$. mcdanieli são favoráveis ao desenvolvimento da espécie. 
- potencial reprodutivo

O potencial reprodutivo de $T$. mcdanieli pode ser considerado alto devido à alta fecundidade das fềmeas, que produzem uma média de 88 ovos a $21^{\circ} \mathrm{C}$ e 126 ovos a $24^{\circ} \mathrm{C}$ e ao grande número de gerações por ano, que varia de 7 a 9 nos EUAN e Canadá (Jeppson et al., 1975; Tanigoshi et al., 1975).

Considerando os parâmetros acima, o potencial de estabelecimento de T. mcdanieli no Brasil é alto devido à disponibilidade de hospedeiros; à adequação das condições climáticas para seu desenvolvimento em algumas das regiões onde seus principais hospedeiros são cultivados; à importação de material para propagação vegetativa potencialmente infestado e ao alto potencial reprodutivo da espécie.

\subsubsection{3 - Tetranychus pacificus McGregor, 1919 (Tetranychidae)}

- Nomes vulgares - "Pacific spider mite", "Pacific mite"

- Distribuição geográfica - América do Norte (Canadá, EUAN e México) $\left(\right.$ Flechtmann $\left.^{36}\right)$.

- Hospedeiros - Amaranthaceae (Amaranthus sp.), Aristolochiaceae (Asarum sp.), Asclepiadaceae (Asclepias sp.), Asteraceae (Helianthus annuus; Madia sativa), Betulaceae (Betula lenta), Convolvulaceae (Ipomoea purpurea), Curcubitaceae (Cucumis spp., Curcubita sp.), Fabaceae (Glycine max, Medicago sativa, M. sp., Phaseolus sp., Robinia pseudoacacia, Thermopsis pinetorum, Trifolium sp., Vicia sp.), Gramineae (Zea mays), Garryaceae (Garrya flavescens), Grossulariaceae (Ribes sp.), Hydrangeaceae (Philadelphus gordonianus), Juglandaceae (Juglans regia), Lamiaceae (Salvia sp.), Magnoliaceae (Magnolia fraseri), Malvaceae (Gossypium sp.), Moraceae (Ficus carica, Morus sp.), Oleaceae (Syringa sp.), Papaveraceae (Bocconia sp., Eschscholtzia

\footnotetext{
${ }^{36}$ FLECHTMANN, C. H. W. (Pesquisador CNPq, Depto. Zoologia, ESALQ, Universidade de São Paulo, Piracicaba, SP). Comunicação pessoal, 1997.
} 
californica), Rhamnaceae (Ceanothus sp., Rhammis betulaefolia), Rosaceae (Cotoneaster sp., Malus domestica, Prunus armeniaca, P. avium, P. domestica, P. dulcis, P. persica, Pyrus communis, Rosa sp., Rubus sp.), Rutaceae (Citrus sp.), Ulmaceae (Ulmus sp.), Vitaceae (Vitis sp.) (Carlson et al., 1970; Dibble, 1979; Flechtmann ${ }^{37}$; Hoy, 1985; Jeppson et al., 1975; Karlik et al.,1995; Pritchard \& Baker, 1952; Rice et al., 1976).

- Características biológicas - $\mathrm{O}$ ciclo de desenvolvimento de $T$. pacificus, de ovo a adulto, requer de 10 a 14 dias. Cada fêmea produz de 50-100 ovos num período de 2 a 4 semanas. O número de gerações por ano depende da duração dos climas de verão (Jeppson et al., 1975; Schruft., 1985).

$\Rightarrow$ Potencial de importância econômica - Alto

\section{- importância econômica e/ou social de seus hospedeiros no Brasil}

T. pacificus é uma espécie polífaga e apresenta um grande número de hospedeiros de importância econômica. No Brasil, pode-se destacar algodão, soja, milho, citros, curcubitáceas, maçã, pêssego, uva e rosas. Dentre estes hospedeiros, milho, soja e algodão são cultivados em grandes extensões. Citros, uva e maçã estão entre as seis frutiferas mais importantes no Brasil, em valor da produção (Tabela 1). Melancia e melão também são frutíferas importantes no país, cultivadas em extensas áreas (Anuário Estatístico do Brasil, 1997). Outra cultura hospedeira deste ácaro de grande importância econômica no país é a de rosas.

- danos e perdas causadas devido às infestações pela espécie

As folhas, começando do topo das plantas, tornam-se marrons e morrem como se tivessem sido chamuscadas por fogo. Em infestações pesadas, as plantas tornam-se cobertas por teia, as folhas secam e as plantas morrem (Jeppson et al., 1975)..

\footnotetext{
${ }^{37}$ FLECHTMANN, C. H. W. (Pesquisador CNPq, Depto. Zoologia, ESALQ, Universidade de São Paulo, Piracicaba, SP). Comunicação pessoal, 1997.
} 
Em alguns hospedeiros, como pêra e citros, sérios efeitos são produzidos por populações relativamente baixas, o que sugere a injeção de toxinas pelos ácaros. Em outros como maçã, uva e feijão, causam manchamentos típicos, como aqueles produzidos por outros tetraniquídeos, devido à remoção de clorofila das células (Jeppson et al., 1975).

A alimentação dos ácaros sobre milho resulta em secamento prematuro da folhagem que reduz a produção de grãos por aumentar o tombamento dos caules, reduzir o tamanho e o conteúdo de água dos grãos (Jeppson et al., 1975).

Na Califórnia, EUAN observou-se que a alimentação de T. pacificus causou uma redução na fotossíntese folhar e na condutância estomatal de videiras (Welter et al., 1989b). Os danos às folhas das videiras causam uma diminuição na maturidade $\mathrm{e}$ qualidade dos frutos (Flaherty et al.,1981 ${ }^{38}$ in Schruft, 1985).

Em amêndoas, a alimentação dos ácaros causou manchamento folhar e desfolha sob densidades populacionais relativamente baixas, quando comparada a infestações por Panonychus ulmi (Koch), Panonychus citri (McGregor) ou Bryobia rubrioculus (Scheuten) (Hoy, 1985).

Juntamente com Tetranychus turkestani (Ugarov \& Nikolskii), infestações de T. pacificus na Califórnia causam desfolha em roseiras, que resulta em injúrias devido à incidência solar, tornando-as sem valor comercial (Karlik et al., 1995).

Em soja, observou-se que a produção foi reduzida quando as populações de T. pacificus e Tetranychus urticae Koch excediam 4-6 ácaros por unidade de amostragem (área circular com um diâmetro de 0,5 polegadas na superfície inferior das folhas) (Carlson, 1969).

Não se dispõe de dados sobre perdas quantitativas causadas por T. pacificus, entretanto, este ácaro é considerado uma das mais importantes pragas em culturas de uvas, amêndoas, maçã, ameixa, pêssego, rosas, curcubitáceas, nozes e soja no oeste dos EUAN (Carlson et al., 1970; Dibble, 1979; Haley \& Baker, 1982; Hoy, 1985; Karlik et al., 1995; Pritchard \& Baker, 1952; Schruft, 1985).

${ }^{38}$ FLAHERTY, D. L.; JENSEN, F. L.; KASIMATIS, A. N.; KIDO, H.; MOLLER, W. J. Grape pest management. Berkeley: University of California, 1981. 312p. (Publ. Agric. Sci, n.4105). 


\section{- medidas utilizadas para o controle da espécie}

Para o controle de T. pacificus têm-se utilizado o controle químico e, em algumas culturas, o controle biológico.

Entre diversos produtos testados para o controle de $T$. pacificus em uva, monocrotofós foi o mais efetivo. Propargite também foi recomendado devido à baixa toxicidade a mamíferos (Stafford \& Kido, 1969). Os pesticidas que apresentaram toxicidade média para $T$. pacificus e baixa para o ácaro predador Galendromus occidentalis (Nesbitt), aconselháveis em programas de controle integrado, foram etiom, carbofenotiom e dialifor (Ali Niazee et al., 1974). Triadimefom, fungicida utilizado para o controle de oídio, levou a um aumento na abundância de ácaros predadores, observandose um declínio nas populações de T. pacificus e Eotetranychus willamettei (McGregor) (Loeb English et al., 1986).

O melhor controle de $T$. pacificus foi obtido utilizando-se grânulos fosforados aplicados no solo na época do plantio e no estágio de plântula ou pulverizações das folhagens com dicofol ou carbofenotiom (Carlson, 1969).

Na Califórnia, T. pacificus é controlado em algodão com o uso de dicofol (Dennehy \& Granett, 1982).

Em videiras, o controle biológico de $T$. pacificus é bastante importante. $O$ predador mais abundante e importante é o ácaro fitoseídeo G. occidentalis. Outros ácaros predadores, principalmente das famílias Bdellidae (Bdella longicornis L.) e Anystidae e insetos predadores, como o tripes Scolothrips sexmaculatus (Pergande) e o coccinelídeo Stethorus punctum (Lec.), também auxiliam a controlar as populações da praga (Kinn \& Doutt, 1972a; Robinson, $1953^{39}$ in Chazeau, 1985; Schruft, 1985; Sorensen et al., 1983).

Liberações do ácaro fitoseídeo G. occidentalis em parreirais controlaram populações de $T$. pacificus não submetidos a tratamentos químicos, levando a um aumento na produção de uvas (Kinn et al., 1974; Kinn \& Doutt, 1972b). A presença de presas alternativas é fundamental para manter altas as populações do ácaro predador,

${ }^{39}$ ROBINSON, A. G. Notes on Stethorus punctum (Lec.) (Coleoptera: Coccinellidae), a predator of tetranychid mites in Manitoba. Annual Report of the Entomological Society of Ontario, p.24-26, 1952. 
possibilitando o controle de $T$. pacificus. $\mathrm{O}$ ácaro tetraniquídeo $E$. willamettei e o tideídeo Homeopronematus anconai (Baker) podem servir como presas alternativas para G. occidentalis quando as populações de $T$. pacificus estão baixas (Flaherty et al., 1972; Knop \& Hoy, 1983).

O controle microbiano de $T$. pacificus também está sendo utilizado em algodão na Califórnia, EUAN. Em testes de campo, Dibeta (thuringiensin) foi efetivo no controle de T. pacificus (Grau, 1987).

\section{- status quarentenário}

T. pacificus é uma espécie considerada quarentenária para os paises integrantes do Cone Sul pelo Comitê de Sanidade Vegetal do Cone Sul (COSAVE) (Brasil, 1995). Desta forma, a introdução da espécie pode levar a restrições na exportação de produtos para países vizinhos, que representam importantes importadores de frutas brasileiras (Brasil, 1994).

O potencial de importância econômica de $T$. pacificus no Brasil é alto, devido ao grande número de hospedeiros de importância econômica no país, por ser uma praga muito séria nas áreas onde ocorre, devido à necessidade de controle químico da espécie $\mathrm{e}$ ao seu status quarentenário em países importadores de produtos brasileiros. $\mathrm{O}$ inimigo natural considerado como mais eficiente no controle de T. pacificus não ocorre no Brasil, portanto, caso a espécie seja introduzida no país, seus danos podem vir a ser mais sérios que nas áreas onde ocorre atualmente.

$\Rightarrow$ Potencial de Introdução - Alto

- possibilidades de infestação dos produtos importados nos países de origem

* presença e abundância da espécie nos países exportadores.

T. pacificus ocorre na América do Norte, sendo uma praga séria especialmente nos EUAN, importante exportador de frutos, flores e mudas que podem estar infestadas 
pela espécie para o Brasil. As principais vias de ingresso identificadas foram uvas e mudas de videiras, maçãs, pêras, pêssegos, nectarinas, ameixas, rosas e mudas de roseiras, melões e amoras dos EUAN (Anexo B, Tabelas 3,4,1,2,6,10,8,11,12,13,14) (Brasil, 1996).

Na Califórnia, T. pacificus é uma praga abundante em culturas de frutíferas, curcubitáceas, rosa, soja e algodão (Carlson et al., 1970; Dibble, 1979; Haley \& Baker, 1982; Hanna et al., 1996; Hoy, 1985; Jeppson et al., 1975; Karlik et al., 1995; Leigh, 1985; Pritchard \& Baker, 1952). Para se ter uma idéia da abundância de T. pacificus nos EUAN, 600-1400 ácaros podem ser encontrados por folha em parreiras pesadamente infestadas (Jeppson et al., 1975).

\section{* volume, frequência e época das importações}

$\mathrm{O}$ volume das importações de produtos potencialmente infestados por $T$. pacificus pelo Brasil têm sido bastante grande. Os EUAN têm sido o principal exportador de uvas, nectarinas e ameixas e o segundo principal exportador de maçãs, pêras e pêssegos para o Brasil (Anexo B, Tabelas 3,10,8,1,2,6) (Brasil, 1996).

A frequência das importações de pêssegos, nectarinas, ameixas, uvas, pêras e maçãs dos EUAN pelo Brasil têm sido altas, tendo sido importados 214, 186, 182, 124, 80 e 49 lotes destas frutas, respectivamente, de janeiro de 1992 a agosto de 1996 (Anexo B, Tabelas 6,10,8,3,2,1) (Brasil, 1996).

As importações de maçãs, pêras e uvas dos EUAN têm sido realizadas durante praticamente todo o ano (Anexo C, Tabelas 1,2,3) (Brasil, 1996), sendo alto o risco de infestação destes frutos, quaisquer que sejam as épocas de ocorrência de picos populacionais da espécie.

No período de janeiro de 1992 a agosto de 1996 foram importadas 2.400 mudas de videiras e 5.214 mudas de roseiras dos EUAN (Anexo B, Tabelas 4 e 12)(Brasil, 1996). 
* ocorrência de $T$. pacificus em frutos embalados.

Uma incidência considerada alta (10 a 60 ácaros/100.000 frutos) de $T$. pacificus foi constatada em frutos de nectarina (Prumus persica v. nucipersica) embalados, quando realizada a inspeção de amostras por um período de 3 anos na Califórnia (Curtis et al., 1992). Issto evidencia a possibilidade de infestação de frutos por T. pacificus nos EUAN.

São muitas as possibilidades de infestação de produtos importados dos EUAN por T. pacificus principalmente devido à abundância da espécie naquele país, ao grande volume e à alta freqüência das importações de produtos potencialmente infestados.

- possibilidades de sobrevivência da espécie às condições de transporte dos materiais.

As fềmeas adultas entram em diapausa no inverno (Jeppson et al., 1975; Schruft, 1985), sendo resistentes a baixas temperaturas neste período. É possivel que fềmeas hibernantes ou prestes a hibernar associadas a frutos sobrevivam às condições de transporte dos mesmos, que normalmente é realizado a temperaturas próximas a zero, no caso dos frutos de clima temperado ou um pouco superior, no caso de melões (Anexo E) (Brasil, 1994).

Os ácaros desta espécie porventura associados a rosas e mudas de roseiras ou de videiras apresentam grandes possibilidades de sobrevivência durante o transporte dos mesmos.

Considera-se, portanto, alta a possibilidade de sobrevivência dos ácaros às condições de tranporte dos produtos potencialmente infestados.

\section{- intercepção de $T$. pacificus em material vegetal importado}

Ácaros desta espécie foram interceptados pelo "Yokohama Plant Protection Station", no Japão, em abóboras importadas dos EUAN (Masaki et al., 1991).

Vários lotes de pêssegos, nectarinas e damascos portando larvas, machos e fềmeas vivas e ovos de $T$. pacificus foram interceptados pelo Serviço de Vigilância 
Agropecuária no Aeroporto Internacional de Guarulhos, São Paulo em junho de 1997 (Flechtmann ${ }^{40}$ ).

Isto exemplifica a possibilidade de infestação de frutos nos EUAN e a sobrevivência dos ácaros às condições de transporte dos mesmos.

Para eliminação de $T$. pacificus de frutos para exportação, vêm sendo estabelecidos tratamentos quarentenários, como fumigação ou utilização de atmosferas controladas. Na Califórnia, resultados preliminares de mortalidade de larvas e adultos de T. pacificus e outros insetos presentes em uvas tratadas com atmosferas controladas com concentrações variáveis de $\mathrm{O}_{2}$ e $\mathrm{CO}_{2}$ indicam que muitos destes tratamentos podem fornecer significativo controle sobre as pragas sem afetar a qualidade do produto (Ahumada et al.,1996).

\section{- possibilidades de detecção dos ácaros na ocasião da chegada de produtos infestados no Brasil.}

\section{* localização na planta hospedeira}

T. pacificus alimenta-se em ambas superficies folhares. As fềmeas hibernantes encontram-se sob ou em ranhuras da casca das plantas hospedeiras (Jeppson et al., 1975; Schruft, 1985), sendo necessária uma detalhada inspeção das plantas para sua detecção.

\section{* dimensões/ coloração da espécie}

Como outros ácaros, as diversas formas de desenvolvimento de $T$. pacificus são pequenas, sendo que as fềmeas medem cerca de $350 \mu \mathrm{m}$ e os machos $256 \mu \mathrm{m}$ de comprimento (Baker \& Tuttle, 1994). Os ácaros são amarelos e apresentam 3 manchas escuras irregulares em cada lado do histerossoma. As fêmeas hibernantes são de coloração alaranjada (Jeppson et al., 1975).

A coloração discreta de alguns estágios de desenvolvimento e as reduzidas dimensões de $T$. pacificus, especialmente de ovos, dificulta a visualização destes ácaros.

\footnotetext{
${ }^{40}$ FLECHTMANN, C. H. W. (Pesquisador CNPq, Depto. Zoologia, ESALQ, Universidade de São Paulo, Piracicaba, SP). Comunicação pessoal, 1997.
} 


\section{* apresentação de sintomas em plantas/produtos infestados}

As folhas infestadas por T. pacificus tornam-se manchadas ou bronzeadas $\mathrm{e}$ posteriormente secam (Jeppson et al., 1975; Schruft, 1985).

A presença de teia sobre as plantas pode sinalizar infestação por T. pacificus, pois estes produzem-a abundantemente (Schruft, 1985).

Consideram-se poucas as possibilidades de deteç̧ão de T.pacificus na ocasião da chegada de produtos infestados no Brasil devido às pequenas dimensões da espécie, à coloração discreta da maioria dos estágios de desenvolvimento e à localização nas plantas hospedeiras, especialmente a de fềmeas hibernantes.

$\Rightarrow$ Potencial de estabelecimento - Alto

\section{- disponibilidade de hospedeiros}

Muitos hospedeiros de T. pacificus são encontrados no Brasil. Devido à grande diversidade de espécies vegetais utilizadas pelo ácaro como hospedeiras, provavelmente, em qualquer região em que forem introduzidos produtos infestados, estes ácaros encontrarão um hospedeiro adequado.

Os hospedeiros de T.pacificus cultivados em áreas mais extensas no Brasil são: milho (14.522.806 ha), algodão herbáceo (1.077.753 ha), soja (11.544.577 ha), citros (992.177 ha), melancia (72.726 ha), melão (11.508 ha), maçã (27.318 ha), uva (60.396 ha) e pêssego (20.188 ha) (Anuário Estatístico do Brasil, 1997).

As importações de produtos potencialmente infestados por T. pacificus têm sido destinadas a estados onde são cultivadas extensas áreas das principais espécies hospedeiras deste ácaro.

As mudas de videiras importadas dos EUAN têm sido destinadas ao Rio Grande do Sul $(83,3 \%)$ e Bahia $(16,7 \%)$ (Anexo D, Tabela 4). O Rio Grande do Sul é principal produtor de uvas, maçãs, pêssegos, pêras, melancia e soja no país. A Bahia, juntamente com Pernambuco, são os principais produtores de uva irrigada, sendo cultivados nesta região 3.899 ha desta frutifera. Também encontram-se, neste estado, extensas áreas de 
culturas de laranja, algodão e melancia (Anuário Estatístico do Brasil, 1997; Brasil, 1996).

Todas as importações de melões e amoras, a quase totalidade das de uvas $(98,7 \%)$, pêssegos $(99,2 \%)$, nectarinas $(99,8 \%)$ e ameixas $(99,9 \%)$ e a maior parte da de maçãs $(61,7 \%)$ e pêras $(83,7 \%)$ dos EUAN têm sido destinadas a São Paulo (Anexo $\mathrm{D}$,Tabelas $3,7,9,8,1,2)$. Este estado é o principal produtor brasileiro de citros, segundo principal produtor de uvas e algodão herbáceo e importante produtor de maçã e pêssego no Brasil (Anuário Estatístico do Brasil, 1997; Brasil, 1996).

Cerca de $20 \%$ das importações de pêras dos EUAN têm sido destinadas a Santa Catarina (Anexo D, Tabela 2), segundo principal produtor de maçãs e pêssegos e importante produtor de uvas no país (Anuário Estatístico do Brasil, 1997; Brasil, 1996).

As importações de mudas de roseiras importadas dos EUAN têm sido destinadas a Minas Gerais, onde são cultivas extensas áreas de milho, feijão e soja e onde encontrase uma importante região produtora de flores, especialmente rosas (Anuário Estatístico do Brasil, 1997; Brasil, 1996).

\section{- uso proposto}

Os ácaros que, porventura, estejam infestando mudas de videiras ou roseiras apresentam um alto potencial de estabelecimento.

- adequação das condições climáticas brasileiras para a sobrevivência, desenvolvimento e reprodução da espécie

As populações de $T$. pacificus aumentam em condições secas e quentes (Flaherty et al., 1972). Em cultivos de rosas na Califórnia, EUAN, a ausência de chuvas de verão e a ocorrência de temperaturas máximas diárias abaixo de $35^{\circ} \mathrm{C}$ favoreceram $\mathrm{o}$ desenvolvimento dos ácaros (Karlik et al., 1995). A espécie prefere parreirais em regiões secas e quentes (Pritchard \& Baker, 1952; Schruft, 1985). As populações de T. pacificus em parreirais irrigados com aspersores foram cerca de metade daqueles não irrigados (Kinn et al., 1974). 
As informações sobre as condições climáticas favoráveis ao desenvolvimento de T. pacificus indicam que a espécie se adaptaria melhor às regiões áridas ou semi-áridas no Brasil. Nestas regiões, encontram-se importantes áreas de produção de hospedeiros da espécie, como uva, algodão e curcubitáceas.

\section{- potencial reprodutivo}

O potencial reprodutivo de T. pacificus é alto. O ciclo de vida é bastante curto, levando de 10 a 14 dias o desenvolvimento de ovo a adulto e a produção de ovos por fềmea é elevado, variando de 50-100 (Jeppson et al., 1975; Schruft, 1985).

Portanto, considera-se alto o potencial de estabelecimento de T. pacificus no Brasil devido à grande disponibilidade de hospedeiros para a praga, à adequação das condições climáticas de algumas regiões no país para seu desenvolvimento e ao alto potencial reprodutivo da espécie.

\subsubsection{4. - Tetranychus schoenei McGregor, 1941 (Tetranychidae)}

- Sinônimo - Septanychus schoenei McGregor, 1950

- Distribuição geográfica - América do Norte (leste e sudeste dos EUAN) (Flechtmann ${ }^{41}$; Jeppson et al., 1975).

- Hospedeiros - Anacardiaceae (Rhus typhina, Toxicodendron radicans), Apocynaceae (Plumeria sp.), Asclepiadaceae (Asclepias purpurascens, A. sp.), Asteraceae (Arctium minus, Solidago altissima, S. graminifolia), Betulaceae (Betula populifolia), Bignoniaceae (Bignonia sp.), Caprifoliaceae (Symphoricarpos foetidus, Viburnum sp.), Celastraceae (Celastrus scandens), Fabaceae (Desmodium canadense, D. canescens, Glycine max, Gymnocladus canadensis, Phaseolus sp., Robinia pseudoacacia),

\footnotetext{
${ }^{41}$ FLECHTMANN, C. H. W. (Pesquisador CNPq, Depto. Zoologia, ESALQ, Universidade de São Paulo,
} Piracicaba, SP). Comunicação pessoal, 1997. 
Fagaceae (Fagus grandifolia), Hydrangeaceae (Philadelphus inodorus), Juglandaceae (Carya glabra, C. illinoensis), Malvaceae (Gossypium hirsutum, G. sp.), Menispermaceae (Menispermum canadense), Moraceae (Morus alba), Rosaceae (Malus coronaria, M. domestica, M. sp., Potentilla anserina, $P$. norvegica, Prumus pensylvanica, $P$. serotina, $P$. sp., Pyrus sp., Rosa multiflora, $R$. palustris, $R$. sp., Rubus allegheniensis, $R$. idaeus, $R$. occidentalis, $R$. odoratus, $R$. sp., Spiraea sp.), Tiliaceae (Tilia sp.), Ulmaceae (Ulmus americana, U. sp.) (Flechtmann ${ }^{42}$ ).

- Características biológicas - O período de eclosão das larvas ao estágio adulto de T. schoenei variou de 23 a 34 dias (Cagle, 1943). Podem ocorrer aproximadamente 9 gerações por ano; formas hibernantes, entretanto, podem apresentar 5 a 8 gerações por ano. As fềmeas produzem até 106 ovos durante sua vida, sendo a produção média 3,7 ovos/dia (Jeppson et al., 1975).

\section{$\Rightarrow$ Potencial de importância econômica - Baixo}

- importância econômica e/ou social de seus hospedeiros no Brasil

São diversos os hospedeiros de $T$. schoenei que apresentam importância econômica no Brasil, destacando-se soja, feijão, algodão, maçã, pêra e rosas. No Brasil, dentre estes hospedeiros, soja, feijão e algodão são cultivados em grandes extensões. A maçã é de grande importância econômica no país (ítem 3.4.1) (Anuário Estatístico do Brasil, 1997; Brasil, 1994;). As rosas são as flores mais apreciadas no Brasil, sendo de grande importância econômica.

\section{- danos e perdas causadas devido às infestações pela espécie}

Em macieiras, a alimentação dos ácaros causa bronzeamento das folhagens e os frutos perdem a cor no outono, sendo necessário vendê-los para a indústria. Infestações severas causam queda prematura de folhas (Cagle, 1943; Jeppson et al., 1975).

${ }^{42}$ FLECHTMANN, C. H. W. (Pesquisador CNPq, Depto. Zoologia, ESALQ, Universidade de São Paulo, Piracicaba, SP). Comunicação pessoal, 1997. 
Não se dispõe de dados sobre perdas quantitativas causadas por T. schoenei. A única referência considerando este ácaro como uma praga é a de Jeppson et al. (1975), que considera esta espécie uma séria praga de maçã, algodão, olmeiros, feijão, sarças, framboesa, ameixas e amoras silvestres.

\section{- medidas utilizadas para o controle da espécie}

Não foram encontradas referências sobre medidas utilizadas para o controle de T. schoenei. Entretanto, sabe-se que populações desta espécie apresentam resistência a organofosforados (Cranham \& Helle, 1985).

O potencial de importância econômica de Tetranychus schoenei para o Brasil é considerado baixo. Encontrou-se apenas uma referência considerando a espécie como praga ocasional, relativamente antiga, sem relatar os danos ou perdas causadas. A ausência de trabalhos sobre medidas de controle também indica pouca importância econômica da espécie.

\subsubsection{5. - Tetranychus turkestani (Ugarov \& Nikolskii, 1937) (Tetranychidae)}

- Sinônimos - Eotetranychus turkestani Ugarov \& Nikolskii, 1937; Tetranychus atlanticus McGregor, 1941

> Nomes vulgares - "strawberry mite", "turkestan spider mite"

- Distribuição geográfica - América Central (Costa Rica), América do Norte (EUAN e México), Europa (Bulgária, França, Espanha, Grécia, Holanda, Ilhas Canárias, Iugoslávia, Hungria, Polônia, Portugal, Suiça), Ásia (CIS, China, Irã, Iraque, Israel, Japão, Paquistão, Turquia), África (África do Sul, Egito, Marrocos), Oceania (Nova Zelândia) (Flechtmann ${ }^{43}$; Hassan et al., 1974).

${ }^{43}$ FLECHTMANN, C. H. W. (Pesquisador CNPq, Depto. Zoologia, ESALQ, Universidade de São Paulo, Piracicaba, SP). Comunicação pessoal, 1997. 
- Hospedeiros - Aceraceae (Acer negundo), Amaranthaceae (Amaranthus albus, A. patulus), Apiaceae (Apium graveolens, Daucus carota, Pimpinella saxifraga), Araliaceae (Aralia sp.), Aristolochiaceae (Asarum canadense), Asclepiadaceae (Asclepias sp.), Asteraceae (Arctium sp., Chrysanthemum sp., Cirsium arvense, Helianthus annuus, Heterotheca subaxillaris, Sonchus sp., Tagetes erecta, Xanthium saccharatum, Zinnia elegans), Balsaminaceae (Impatiens noli-tangere), Betulaceae (Corylus avellana), Cannabaceae (Humulus lupulus), Caprifoliaceae (Diervilla lonicera), Caryophyllaceae (Dianthus sp., Stellaria nemorum), Chenopodiaceae (Chenopodium album), Convolvulaceae (Convolvulus arvensis, C. sp., Cressa cretica), Curcubitaceae (Citrullus lanatus, Cucumis melo, C. sativus, Curcubita maxima, C. moschata), Ebenaceae (Diospyros sp.), Euphorbiaceae (Manihot sp., Ricinus communis), Fabaceae (Arachis hypogeae, Glycine max, Glycyrrhiza glabra, Lathyrus odoratus, Lupinus sp., Melilotus sp., Medicago sativa, Phaseolus vulgaris, P. sp., P. lunatus, Sesbania aegyptiaca, Trifolium incarnatum, Vigna mungo, Vicia faba), Grossulariaceae (Ribes nigrum, Ribes sp.), Hydrangeaceae (Philadelphus coronarius), Juglandaceae (Juglans regia), Lamiaceae (Galeopsis speciosa, G. tetrahit, Glechoma hederaceae, Lamium album, Mentha sp.), Magnoliaceae (Liriodendron tulipifera, Magnolia acuminata), Malvaceae (Abelmoschus esculentus, Abutilon avicennae, Gossypium hirsutum, G. sp., Hibiscus cannabinus, Malva neglecta, M. parviflora), Moraceae (Ficus carica, Morus alba, M. sp.), Oleaceae (Fraximus americana, Jasminum sambac, Ligustrum sp.), Papaveraceae (Papaver sp., Sanguinaria canadensis), Plantaginaceaea (Plantago major), Poaceae (Zea mays), Polygonaceae (Polygonum argyrocoleon, P. aviculare, P. nodosum), Primulaceae (Lysimachia vulgaris, Primula officinalis), Ranunculaceae (Aquilegia sp.), Rosaceae (Cydonia oblonga, Fragaria vesca, Fragaria sp., Malus domestica, Potentilla sp., Prunus avium, $P$. domestica, $P$. dulcis, $P$. pensylvanica, Prunus persica, Rosa sp., Rubus idaeus), Rutaceae (Citrus sp.), Salicaceae (Populus tremula, Salix sp.), Solanaceae (Capsicum sp., Datura stramonium, Lycopersicon esculentum, Solanum elaegnifolium, S. melongena), Ulmaceae (Ulmus americana, U. pumila), Urticaceae (Urtica dioica), Verbenaceae (Verbena sp.), Violaceae (Viola 
sp.), Vitaceae (Vitis vinifera) (Atanasov et al., 1983; Balevski \& Ganova Lazarova, 1973; Flechtmann ${ }^{44} ;$ Hoy, 1985).

Características biológicas - $\mathrm{O}$ tempo médio de desenvolvimento de T. turkestani é de 26-29 dias a $15,5^{\circ} \mathrm{C}$ e $6-7$ dias a $29,4^{\circ} \mathrm{C}$ para as fềmeas e um pouco mais curto para os machos (Carey \& Bradley, 1982). O limiar inferior de desenvolvimento é $7,3^{\circ} \mathrm{C}$ (Uspenskii, 1978). Observam-se de 8 a 16 gerações por ano (Jeppson et al., 1975). Na Bulgária observam-se de 10 a 11 gerações e em CIS, em áreas de cultivo de algodão, de 11 a 15 gerações por ano (Atanasov, 1983; Uspenskii, 1978). No Iraque, a produção de ovos por fêmea é de cerca de 82 ovos a $25^{\circ} \mathrm{C}$ e nos EUAN, a progênie a $23,8^{\circ} \mathrm{C}$ é de 85 ovos e a $29,4^{\circ} \mathrm{C}$ é de 73 ovos (Al Mallah \& Abdalla, 1990; Carey \& Bradley, 1982).

\section{$\Rightarrow$ Potencial de importância econômica - Alto}

\section{- importância econômica e/ou social de seus hospedeiros no Brasil}

T. turkestani é uma praga polífaga, que apresenta um grande número de hospedeiros de importância econômica no Brasil. Podem-se destacar soja, feijão, algodão, milho, maçã, pêssego, uva, curcubitáceas e rosas, que são seriamente prejudicadas pela praga em outros países. Milho, soja, feijão e algodão são cultivados grandes extensões no Brasil. Uva, maçã e pêssego são a quarta, sexta e décima primeira principais frutiferas no Brasil, respectivamente, em valor da produção. Melancia e melão também são importantes no Brasil, cultivadas em extensas áreas (Anuário Estatístico do Brasil, 1997). As rosas são as flores mais apreciadas no Brasil, sendo sua cultura de importância econômica no país.

- danos e perdas causadas devido às infestações pela espécie

Populações numerosas causam queda de folhas e morte das plantas (Jeppson et al., 1975). Não há uma relação linear entre a alimentação dos ácaros e a diminuição na

\footnotetext{
${ }^{44}$ FLECHTMANN, C. H. W. (Pesquisador CNPq, Depto. Zoologia, ESALQ, Universidade de São Paulo, Piracicaba, SP). Comunicação pessoal, 1997.
} 
taxa fotossintética, indicando que os ácaros injetam toxinas nas plantas durante a alimentação (Brito et al., 1986; Jeppson et al., 1975).

Infestações de T. turkestani causam severa e rápida desfolha de algodão nos EUAN, podendo haver perda total de botões florais e frutos (Leigh, 1985). Este ácaro é considerado a espécie mais nociva do gênero Tetranychus que infesta algodão na Califórnia (Brito et al., 1986). As infestações reduzem a produtividade em mais de $22 \%$, havendo uma diminuição no tamanho das maçãs de algodão, na viabilidade das sementes e na produção de fios, além de retardamento na maturação (Jeppson et al., 1975). No Kasaquistão, infestações no início do desenvolvimento das plantas inibiu significantemente o crescimento e levou a uma redução de $61,6 \%$ na produtividade, enquanto que infestações mais tardias reduziram-a em 43,7\%.(Wehner, 1989).

Na França e Bulgária, as infestações de T. turkestani têm causado o secamento e queda prematura das folhas de milho (Fauvel et al., 1987; Nikolov et al., 1983). Na França, quando infestações ocorreram nas 3 semanas anteriores à floração, o comprimento das espigas e o peso dos grãos foram afetados, resultando em perdas de $20 \%$ ou mais (Fauvel et al., 1987).

Não se dispõe de dados sobre perdas quantitativas devido às infestações por T. turkestani em frutíferas. Têm sido relatados danos à videira na França, principalmente na costa do Mediterrâneo e na Hungria (Bozai, 1976; Rambier, 1979; Schruft, 1985); à maçã (Van de Vrie, 1985a); ao morango, na costa Atlântica dos EUAN e na Bulgária (Atanasov, 1983; Wysoki, 1985); ao pêssego e pêra na França (Bassino et al., 1975; LeClant \& Milaire, 1975) e à amêndoa na Califórnia, EUAN (Hoy, 1985).

T. turkestani é uma das pragas mais sérias e amplamente distribuidas nos EUAN, Europa, CIS, Japão e países do Oriente Médio e Oriente Próximo (Jeppson et al., 1975). Nos EUAN, é uma praga importante de amêndoa, curcubitáceas, rosa, soja e algodão (Dennehy \& Granett, 1984; Dibble, 1979; Hoy, 1985; Karlik et al., 1995; Miller \& Cornell, 1974). Na Europa, é considerado uma praga de milho na França e Bulgária (Fauvel et al., 1987; Nikolov et al., 1983); de uva, pêra, pêssego e soja na França (Bassino et al., 1975; Blanc, 1988; LeClant \& Milaire, 1975; Rambier, 1979); e de flores em casas-de-vegetação, pimentão e amendoim na Bulgária (Atanasov, 1971; Atanasov et 
al., 1983; Balevski \& Ganova Lazarova, 1973). Na Ásia, é uma praga séria de algodão no sul do Kasaquistão, Tadiquistão (CIS) e Irã (Couillaud \& Aubertin, 1970; De Millo, 1979; Wehner, 1989) e de girassol no Irã (Navvab Gojrati \& Zare, 1978ab). Na África, especialmente no Egito, também é uma praga em algodão (Hassan et al., 1974).

\section{- medidas utilizadas para o controle da espécie}

Para o controle de $T$. turkestani na maioria das culturas que infesta utilizam-se pesticidas. Populações da espécie somente têm desenvolvido resistência a organofosforados (Cranham \& Helle, 1985), não tendo sido relatados problemas no controle com outros grupos de pesticidas.

Em algodão, a praga tem sido controlada por propargite, dicofol, chlorpirifós, abamectina e enxofre (Al"Ne Ami, 1981; Grafton et al., 1987; Leigh et al., 1990). Em milho, quando as infestações são esporádicas, pode-se utilizar acaricidas clássicos como cihexatina ou dicofol, entretanto, quando ocorrem regularmente, recomenda-se hexitiazox ou clofentezine (Fauvel et al., 1987). Em videiras, na Hungria, recomendam-se pulverizações antes da quebra da dormência das gemas utilizando-se formotiom, dimetoato ou fosfamidom (Bozai, 1976). Na Bulgária, em morango, framboesa e "black currant", os acaricidas mais eficientes foram dicofol, azociclotina, óxido de difenildiazene, dinobutom e uma mistura de dicofol e dinocap (Atanasov, 1983).

Diversos predadores têm sido associados a $T$. turkestani e muitos deles são considerados eficientes. Entretanto, suas densidades populacionais muitas vezes não são suficientes para controlar as infestações (Fauvel et al., 1987; Nikolov et al., 1983). Podem-se destacar os tripes Frankliniella occidentalis (Pergande) e Scolothrips sp.; os antocorídeos Geocoris pallens, Orius tristicolor (White), Orius albidipennis (Reut.) e Orius sp.; os coccinelídeos Stethorus gilvifrons (Muls.), Stethorus punctillum (Weise) e Scymnus spp.; o crisopídeo Chrysopa sp. e o ácaro fitoseídeo Amblyseius andersoni (Chant) (Ahmed \& Ahmed, 1988; Atanasov, 1983; Fatemi, 1983b; Fauvel et al., 1987; Georgis, 1977; Leigh et al., 1990; Nikolov et al., 1983; Rajkovic, 1988; Selim, 1977).

O controle biológico tem sido utilizado com sucesso em algumas culturas. Liberações de ácaros fitoseídeos são realizadas em culturas de morango, pimentão e em 
pomares de amêndoa. Na Bulgária, liberações de Phytoseiulus persimilis Athias-Henriot foram efetivas para o controle de T. turkestani, reduzindo a necessidade de aplicação de pesticidas em culturas de pimentão e morango (Atanasov, 1983; Atanasov et al., 1983). Em pomares de amêndoa, na Califórnia, têm sido utilizados biótipos de Galendromus occidentalis (Nesbitt) (Cameron et al., 1982).

Portanto, o potencial de importância econômica de T. turkestani no Brasil é alto devido ao grande número de hospedeiros de importância econômica no pais; à seriedade das perdas e problemas que vêm causando em outros países e à necessidade de aplicação de pesticidas para seu controle.

\section{$\Rightarrow$ Potencial de Introdução - Alto}

- possibilidades de infestação dos produtos importados nos países de origem

* presença e abundância da espécie nos países exportadores.

T. turkestani ocorre em vários países exportadores de produtos que podem estar infestados pela espécie para o Brasil. As principais vias de ingresso identificadas foram: morango, roseira e melão dos EUAN; pêssegos, pêras e mudas de videiras da França e pêssegos da Espanha (Anexo B, Tabelas 15, 12, 13, 6, 2,4) (Brasil, 1996).

T. turkestani é abundante nos países exportadores de produtos potencialmente infestados. Nos EUAN, este ácaro é uma importante praga de rosas e curcubitáceas (melão e abóboras), principalmente na Califórnia, e de morango, nos estados da costa do Atlântico (Dibble, 1979; Jeppson et al., 1975; Karlik et al., 1995). Na França, T. turkestani é uma das principais pragas de pêras e pêssegos, também causando danos a videiras (Bassino et al., 1975; LeClant \& Milaire, 1975; Rambier, 1979). Na Espanha, T. turkestani é uma das espécies de Tetranychus mais importantes, representando $25 \%$ dos espécimens coletados e sendo encontrado em todo o país (Ferragut \& Santonja, 1989; Villaronga et al., 1993). 
* volume, frequência e época das importações

O volume das importações de produtos potencialmente infestados por T. turkestani é bastante grande. Os EUAN têm sido o principal exportador de morangos para o Brasil, tendo exportado cerca de $235 \mathrm{t}$ no período de janeiro de 1992 a agosto de 1996 (Anexo B, Tabela 15). A França tem sido o quarto principal exportador de pêras para o Brasil, tendo exportado cerca de $3.946 \mathrm{t}$ neste mesmo período (Anexo B, Tabela 2). Um grande número de mudas de videiras têm sido importadas da França e de roseiras dos EUAN pelo Brasil (Anexo B, Tabelas 4 e 12) (Brasil, 1996).

As importações de morangos dos EUAN, de pêssegos da Espanha, de pêras da França pelo Brasil têm sido freqüentes, tendo sido importados 87,10 e 9 lotes destes frutos, respectivamente, no período considerado (Anexo B, Tabelas 15, 6 e 2) (Brasil, 1996).

Em culturas de rosas, na Califórnia, observou-se que a porcentagem de folhas infestadas por $T$. turkestani e $T$. pacificus aumentou no período de março a abril, mantendo-se em um nível alto até agosto e diminuindo em setembro (Karlik et al., 1995). As importações de maior número de roseiras dos EUAN têm sido realizadas em maio $\mathrm{e}$ junho, período em que os níveis populacionais da espécie estão altos (Anexo C, Tabela 12) (Brasil, 1996). Portanto, são altas as possibilidades de infestação de roseiras importadas dos EUAN por T. turkestani.

As importações de morangos dos EUAN têm sido realizadas durante quase todo o ano, exceto em dezembro (Anexo C, Tabela 10) (Brasil, 1996), sendo alto o risco de infestação destes frutos, quaisquer que sejam as épocas de ocorrência de picos populacionais da espécie.

Considerando os parâmetros acima, são muitas as possibilidades de infestação de produtos importados por $T$. turkestani, devido à abundância da espécie nos países exportadores, aos grandes volumes e à alta frequência das importações de produtos potencialmente infestados. 
- possibilidades de sobrevivência da espécie às condições de transporte dos materiais.

As fềmeas adultas de T. turkestani entram em diapausa no inverno (Jeppson et al., 1975), sendo resistentes a baixas temperaturas neste período. É possível que fêmeas hibernantes ou prestes a migrar para os locais de hibernações associadas a frutos sobrevivam às condições de transporte dos mesmos, que é realizado a temperaturas próximas a zero, no caso de morangos e pêras, e um pouco superior, no caso de melões (Anexo E) (Brasil, 1994).

Ácaros desta espécie infestando rosas, roseiras e mudas de videiras importadas apresentam grandes possibilidades de sobrevivência às condições de transporte dos mesmos.

Portanto, considera-se alta a possibilidade de sobrevivência destes ácaros às condições de tranporte dos produtos potencialmente infestados.

- possibilidades de deteç̧ão dos ácaros na ocasião da chegada de produtos infestados no Brasil.

\section{* localização na planta hospedeira}

Os ácaros formam colônias e alimentam-se principalmente na superficie inferior das folhas, entretanto, quando as densidades populacionais são altas, formas móveis são encontradas também nos caules, gemas e frutos imaturos (Atanasov, 1970).

As fềmeas hibernantes são encontradas na matéria orgânica do solo ou sob a casca solta dos troncos (Jeppson et al., 1975), portanto, para que sejam detectadas, é necessária uma minuciosa inspeção destas áreas.

\section{* dimensões/ coloração da espécie}

Como as outras espécies de ácaros, as diversas formas de desenvolvimento de T.turkestani são bastante pequenas. As fềmeas medem cerca de $456 \mu \mathrm{m}$ e os machos $285 \mu \mathrm{m}$ de comprimento (Baker \& Tuttle, 1994). 
Os ovos de $T$. turkestani são quase incolores, tornando-se opacos e finalmente marfins, antes da eclosão das larvas. As larvas recém eclodidas são pálidas, quase incolores, tornando-se em seguida esverdeadas, com manchas escuras em cada lado do corpo. As protoninfas e deutoninfas apresentam coloração palha, com manchas laterais. A coloração das fềmeas é variável, podendo ser âmbar, verde, marrom ou quase pretas. As fềmeas hibernantes são de coloração laranja-brilhantes (Jeppson et al., 1975). Observa-se, portanto, que a maioria das formas de desenvolvimento de T. turkestani apresentam colorações discretas, com exceção das fêmeas hibernantes, as quais normalmente permanecem em locais protegidos, dificultando sua detecção.

* apresentação de sintomas em plantas/produtos infestados

As folhas infestadas por T. turkestani apresentam, em sua superficie superior, áreas mortas nos locais correspondentes aos pontos de alimentação dos ácaros na superficie inferior (Jeppson et al., 1975).

Estes ácaros produzem teia, portanto, a presença desta sobre as plantas ou frutos pode sinalizar infestação pela espécie (Jeppson et al., 1975).

\section{- intercepção de $T$. turkestani em material vegetal importado}

Ácaros desta espécie foram interceptados pelo "Yokohama Plant Protection Station", no Japão, em abóboras importadas dos EUAN. T. turkestani ainda não havia sido assinalado no Japão (Masaki et al., 1991). Isto exemplifica a possibilidade de infestação de frutos em países onde a espécie ocorre e a sobrevivência dos ácaros às condições de transporte dos mesmos.

Consideram-se poucas as possibilidades de detecção de T. turkestani na ocasião da chegada de produtos infestados no Brasil devido às suas reduzidas dimensões e colorações discretas, por poderem estar em locais protegidos nos hospedeiros e à carência de técnicos adequadamente treinados para detecção de ácaros em material vegetal no país. 


\section{$\Rightarrow$ Potencial de estabelecimento - Alto}

\section{- disponibilidade de hospedeiros}

Muitos hospedeiros de T. turkestani são encontrados no Brasil. Devido à grande diversidade de espécies vegetais utilizadas pelo ácaro como hospedeiras, provavelmente, em qualquer região em que forem introduzidos produtos infestados, estes ácaros encontrarão hospedeiros adequados.

Os hospedeiros de T. turkestoni cultivados em áreas mais extensas no Brasil são: milho (14.522.806 ha), algodão herbáceo (1.077.753 ha), soja (11.544.577 ha), feijão (5.729.765 ha), amendoim (91.898 ha), citros (992.177 ha), melancia (72.726 ha), melão (11.508 ha), caqui (4.754 ha), maçã (27.318 ha), uva (60.396 ha), pêssego (20.188 ha) e tomate (62.186 ha) (Anuário Estatístico do Brasil, 1997).

As importações de produtos potencialmente infestados por T. turkestani têm sido destinadas a estados onde são cultivadas extensas áreas das principais espécies hospedeiras deste ácaro.

As mudas de videiras importadas da França têm sido destinadas ao Rio Grande do Sul (Anexo D, Tabela 4), principal produtor de uva, maçã, pêssego, pêra, melancia e soja e importante produtor de caqui no Brasil (Anuário Estatístico do Brasil, 1997; Brasil, 1996).

Todas as importações de pêssegos da Espanha e França, de melões dos EUAN e a quase totalidade das de morangos dos EUAN e cerca de $70 \%$ das de pêras da França têm sido destinadas a São Paulo (Anexo D, Tabelas 7, 10, 2), principal produtor de citros, amendoim, tomate e caqui; segundo principal produtor de uvas e algodão herbáceo e importante produtor de maçã e pêssego no Brasil (Anuário Estatístico do Brasil, 1997; Brasil, 1996).

Cerca de 30\% das importações de pêras da França têm sido destinadas a Santa Catarina (Anexo $\mathrm{D}$, Tabela 2), segundo principal produtor de maçãs e pêssegos e importante produtor de uvas no país (Anuário Estatístico do Brasil, 1997; Brasil, 1996).

As importações de mudas de roseiras importadas dos EUAN têm sido destinadas

a Minas Gerais, onde são cultivadas extensas áreas de milho, feijão e soja e onde 
encontram-se regiões produtoras de rosas (Anuário Estatístico do Brasil, 1997; Brasil, 1996).

Portanto, há grande disponibilidade de hospedeiros de T. turkestani no Brasil, especialmente nos estados para onde têm sido destinados os produtos potencialmente infestados pela espécie.

\section{- uso proposto}

Os ácaros desta espécie que porventura estejam infestando mudas de videiras ou roseiras apresentam um alto potencial de estabelecimento.

- adequação das condições climáticas brasileiras para a sobrevivência, desenvolvimento e reprodução da espécie

Altas temperaturas diárias e limitada pluviosidade favorecem o desenvolvimento de T. turkestani (Jeppson et al., 1975). No Irã, observou-se que um dos principais fatores afetando a flutuação populacional desta espécie foi a umidade relativa; os picos populacionais ocorrem em seguida a períodos de baixa umidade relativa (Fatemi, 1983a). Em cultivos de algodão na Califórnia, $T$. turkestani é a espécie predominante no final da primavera e começo do verão (Leigh, 1985).

As informações sobre as condições climáticas favoráveis ao desenvolvimento de T. turkestani indicam que a espécie se adaptaria melhor às regiões mais secas no Brasil, que podem ser encontradas principalmente na região Nordeste e parte da Centro-Oeste. Nestas regiões encontram-se extensas áreas de hospedeiros da espécie, como uva, algodão, curcubitáceas, soja e milho.

\section{- potencial reprodutivo}

O potencial reprodutivo de $T$. turkestani é alto. $\mathrm{O}$ ciclo de vida da espécie é relativamente curto, variando de 6 a 30 dias, dependendo da temperatura (Carey \& Bradley, 1982). Observa-se um grande número de gerações por ano, variando de 8 a 16 
(Jeppson et al., 1975). A produção de ovos por fềmea é elevada, sendo de 81,7 ovos a $25^{\circ} \mathrm{C}$ (Al Mallah \& Abdalla, 1990).

O potencial de estabelecimento de T. turkestani no Brasil é considerado alto devido à grande disponibilidade de hospedeiros para a espécie no país, ao alto potencial reprodutivo da espécie, à adequação das condições climáticas de algumas regiões no país ao desenvolvimento da espécie e à importação de material para propagação vegetativa potencialmente infestado.

\subsubsection{6 - Tetranychus urticae Koch, 1836 (Tetranychidae)}

- Sinônimos - Acarus telarius Linnaeus, 1758; Tetranychus telarius (Linnaeus, 1758); Acarus sambuci Schrank, 1781; Tetranychus sambuci (Schrank, 1781); Tetranychus dugesii Cano \& Alcacio, 1896; Tetranychus textor Oudemans, 1929; Tetranychus russeolus Koch, 1838; Tetranychus viburni (Koch, 1838); Tetranychus fervidus Koch, 1841; Acarus cucumeris Boisduval, 1867; Tetranychus cucumeris (Boisduval, 1867); Acarus rosarum Boisduval, 1867; Tetranychus rosarum (Boisduval, 1867); Acarus cinnabarinus Boisduval, 1867; Tetranychus cinnabarinus (Boisduval, 1867); Acarus haematodes Boisduval, 1867; Tetranychus telarius haematodes (Boisduval, 1867); Acarus ferrugineus Boisduval, 1867; Tetranychus ferrugineus (Boisduval, 1867); Acarus vitis Boisduval, 1867; Tetranychus vitis (Boisduval, 1867); Distigmatus pilosus Donnadieu, 1875; Tetranychus major Donnadieu, 1875; Tetranychus piger Donnadieu, 1875; Tetranychus minor Donnadieu, 1875; Tetranychus longitarsus Donnadieu, 1875; Tetranychus plumistoma Donnadieu, 1875; Tetranychus fici Mirray, 1877; Tetranychus eriostemi Murray, 1877; Tetranychus inaequalis Targioni Tozzetti, 1878; Tetranychus bimaculatus Harvey, 1892; Tetranychus altheae von Hanstein, 1901; Epitetranychus hamatus Zacher, 1916; Epitetranychus aequans Zacher, 1916; Epitetranychus alceae Oudemans, 1928; Tetranychus reinwardtiae (Oudemans, 1930); Epitetranychus caldarii 
Oudemans, 1931; Tetranychus caldarii (Oudemans, 1931); Tetramychus fragariae Oudemans, 1931; Tetranychus fransseni Oudemans, 1931; Tetranychus aspidistrae Oudemans, 1931; Tetramychus choisyae Oudemans, 1931; Tetranychus stellaria Oudemans, 1931; Tetranychus violae Oudemans, 1931; Tetranychus manihotis Oudemans, 1931; Eotetranychus inexspectatus André, 1933; Tetranychus dahliae Oudemans, 1937; Eotetranychus scabrisetus Ugarov \& Nikolskii, 1937; Eotetranychus curcubitacearum Sayed, 1946; Tetranychus multisetis Mc Gregor, 1950; Tetranychus arabicus Attiah, 1967; Tetranychus aduncus Flechtmann \& Baker, 1967; Tetranychus ricinus Saba, 1973 (Flechtmann ${ }^{45}$ )

- Nomes vulgares - -"two spotted spider mite", ácaro rajado

- Distribuição geográfica - é relatada a ocorrência da espécie em 98 países (Flechtmann ${ }^{45}$ )

- Hospedeiros - T. urticae é a espécie que apresenta maior número de hospedeiros entre os ácaros tetraniquídeos, infestando cerca de 900 espécies vegetais, incluindo a maioria das culturas agrícolas e plantas ornamentais (Flechtmann ${ }^{45}$; Jeppson et al., 1975; Van de Vrie, 1985a).

- Situação da praga no Brasil - No Brasil, T. urticae encontra-se amplamente distribuido, causando problemas a diversas culturas. São poucos os trabalhos sobre resistência de $T$. urticae no país, como pode-se observar na Tabela 9. Os níveis de resistência a pesticidas apresentados pelo ácaro rajado no Brasil são baixos, quando comparados aos níveis apresentados em outros países. Desta maneira, não é desejável a introdução de biótipos resistentes a pesticidas através da importação de produtos vegetais, que complicariam seriamente os programas de controle da praga, podendo levar a aumento nos custos de produção e a problemas ambientais.

\footnotetext{
${ }^{45}$ FLECHTMANN, C. H. W. (Pesquisador CNPq, Depto. Zoologia, ESALQ, Universidade de São Paulo, Piracicaba, SP). Comunicação pessoal, 1997.
} 
$\Rightarrow$ Potencial de importância econômica - Alto

\section{- importância econômica e/ou social de seus hospedeiros no Brasil}

No Brasil, as culturas de importância econômica às quais o ácaro rajado vêm causando problemas são: algodão, feijão, maçã, mamão, mamona, mandioca, morango, ornamentais, pêssego, soja e tomate (Anuário Estatístico do Brasil, 1997; Flechtmann, 1985).

- danos e perdas causadas devido às infestações pela espécie

T. urticae é uma das espécies de ácaros de maior importância econômica e mais nociva (Jeppson et al., 1975; Rabbinge, 1985).

O nível de dano de plantas ornamentais em casas-de-vegetação às infestações por T. urticae é extremamente baixo devido ao valor estético das folhagens. Em rosas da cultivar Sonia, o confinamento de 5 fềmeas adultas jovens em folhas recém-expandidas resultou em danos conspícuos após 1 dia (Van de Vrie, 1985a).

Em espécies hortícolas em casas-de-vegetação no Reino Unido e Holanda, o então denominado $T$. cimnabarimus, atualmente considerado sinônimo de $T$. urticae $\left(\right.$ Flechtmann ${ }^{46}$ ), foi relatado causando uma forma distinta de dano, que parece estar relacionado à injeção de toxinas. Neste caso, poucos ácaros foram suficientes para causar sérios danos. Ao invés de manchas típicas, os foliolos infestados tornam-se prematuramente cloróticos com pequenas lesões transparentes, assemelhando sintoma de deficiência de magnésio. Regiões amarelo-brilhantes desenvolvem-se sobre os folíolos. Estas regiões tornam-se necróticas e coalescem gradualmente até que toda a folha murche e morra (Foster \& Barker, 1978).

$\mathrm{Na}$ California, EUAN, pomares inteiros de amêndoa tornam-se desfolhados e severos danos podem ocorrer rapidamente em julho e agosto (Hoy, 1985).

Em citros, a alimentação de $T$. urticae sobre folhas jovens causa depressões e áreas cloróticas que também são visíveis na superfície superior. Os ácaros também podem

${ }^{46}$ FLECHTMANN, C. H. W. (Pesquisador CNPq, Depto. Zoologia, ESALQ, Uníversidade de São Paulo, Piracicaba, SP). Comunicação pessoal, 1997. 
se alimentar em frutos verdes causando bronzeamento quando estes amadurecem (McMurtry, 1985).

Em videiras, um alto grau de desfolhação ocorre devido às infestações por T. urticae, com consequências para a maturação e qualidade dos frutos. Os cachos de uvas também são atacados, o que causa o aparecimento de manchas escuras sobre a casca (Schruft, 1985). Na África do Sul, altos níveis populacionais das formas de verão de T. urticae causaram bronzeamento das margens das folhas mais novas, que permaneceram pequenas e deformadas e, em seguida, murcharam e cairam prematuramente. Folhas mais velhas apresentam clorose (Schwartz; 1990). Na Tchecoslováquia, Hluchy \& Pospisil (1991) constataram uma relação significante entre a densidade de infestação de eriofí́deos e T. urticae e o peso das uvas. Na Espanha, videiras que haviam sido tratadas com deltametrina, para o controle de Lobesia botrana Den. \& Schiff (Lepidoptera: Tortricidae), foram totalmente desfolhadas por T. urticae, o que reduziu o grau Baumé do suco de uva. As videiras desfolhadas tiveram os frutos, estacas e brotos atacados. As videiras danificadas brotaram tardiamente e produziram somente brotos raquíticos (Arias Giralda \& Nieto Calderon, 1982). Na Suiça, uma redução significativa na qualidade e quantidade da produção ocorreu quando o dano folhar foi sério (Baillod et al.; 1989). Na Europa, T. urticae é considerado uma das principais pragas de videiras (Kassemeyer, 1996).

Severas infestações em lúpulo causam mosqueamento das folhas, com grande produção de teia; os ácaros também alimentam-se sobre os estróbilos, que tornam-se secos, vermelhos e quebradiços, tendendo a despedaçar. A qualidade e a produção pode ser grandemente reduzida e podem ocorrer perdas totais (Cranham, 1985).

Em algodão, Cannerday \& Arant (1964) relataram perdas de produtividade de 14$44 \%$ e perdas na qualidade das fibras e sementes associadas à infestação por $T$. urticae. No Brasil, as infestações de T. urticae em algodoeiros causaram redução de até $25 \%$ na produção e afetou a qualidade das fibras (Oliveira, 1972).

Populações de $T$. urticae aumentam rapidamente em morangueiros nos EUAN durante a estação de crescimento, causando redução na quantidade e qualidade dos frutos (Sances et al., 1982). Na África do Sul, quando a cultura de morango não é tratada 
adequadamente, as perdas na produção podem alcançar $50 \%$ devido às infestações por esta espécie (Coates, $1974^{47}$ citado por Wysoki, 1985).

\section{- medidas utilizadas para o controle de $T$. urticae}

Para o controle de T. urticae têm-se utilizado principalmente o controle químico. Entretanto, em algumas culturas, especialmente de frutiferas ou em culturas em casa-devegetação, pode-se utilizar o controle biológico, muitas vezes em associação com o controle químico.

Os métodos de controle aplicáveis dependem do hospedeiro, bem como da utilização prévia de pesticidas, devido ao rápido desenvolvimento de resistência a acaricidas (Jeppson et al., 1975). Há um grande número de trabalhos relacionados ao controle químico de T. urticae.

Os acaricidas que têm se mostrado mais eficientes para o controle de $T$. urticae são formetanato e dinobutom em Taiwan (Wu et al., 1985); bifentrina, fluvalinato e azociclotina na Austrália (Gough, 1990); hexitiazox e clofentezine nos EUAN (Rock, 1987); bromopropilato, abamectina, clorfensom, fenpyroximato, azociclotina e hexitiazox na Coréia (Song et al., 1995; Ahn et al., 1996); cihexatina, propargite, clorfenetol e clorfensom em CIS (Litvinov et al., 1985); aldicarb, na Tchecoslováquia e EUAN (Cranham, 1985); flucicloxurom em macieiras na Hungria (Kuijpers \& Zwaan, 1992); amitraz na Espanha, Itália, França, África do Sul e Reino Unido (Aveyard, 1988); clofentezine em macieiras na Holanda (Mandersloot, 1987); bromopropilato em videiras na Ucrânia (Bol'Shakova \& Litvinov, 1994); hexitiazox e bifentrina em videiras na Romênia (Turcanu, 1992); clofentezine e hexitiazox em videiras na Suiça (Boller, 1988).

Nos EUAN, o controle biológico têm sido utilizado em pomares e em culturas de morango. Em pomares de amêndoa na Califórnia, o desenvolvimento de um manejo integrado tem sido baseado na utilização de biótipos do ácaro predador Galendromus occidentalis (Nesbitt) resistentes a alguns pesticidas em combinação com o uso de doses abaixo das recomendadas dos acaricidas seletivos propargite e cihexatina (Hoy, 1985).

${ }^{47}$ COATES, T. J. D. The influence of some natural enemies and pesticides on various populations of Tetranychus cinnabarinus (Boisduval), T. lombardinii Baker and Pritchard and T. ludeni Zacher (Acari: Tetranychidae) with aspects of their biologies. Repubublic of South Africa, Department of Agriculture, Technical Service, Entomological Memoirs., v.42, p.1-40, 1974. 
Em morango, bons resultados têm sido obtidos na utilização de ácaros predadores (Phytoseiulus persimilis Athias-Henriot, G. occidentalis e Neoseiulus californicus (McGregor)) (Oatman et al., 1977).

Em maçã na Suiça e Itália, resultados promissores foram obtidos em um pequeno pomar onde se utilizou o controle integrado por 3 anos, liberando-se o ácaro predador Typhlodromus pyri Scheuten e utilizando-se acaricidas seletivos para o controle de Panonychus ulmi (Koch) e T. urticae (Baillod et al., 1982b).

$\mathrm{Na}$ Holanda, em culturas de uva em casa-de-vegetação, framboesa, pêssego e ameixa, $P$. persimilis foi efetivo, mesmo que em pequenos números, não sendo necessária a aplicação de controle químico (Wildeman, 1975).

Biótipos de ácaros predadores resistentes a alguns pesticidas têm sido utilizados para o controle de T. urticae em alguns países. Populações de G. occidentalis resistentes a inseticidas organofosforados foram introduzidas de Michigan, EUAN e liberadas em parreirais na Geórgia (CIS) (Chubinnishvili et al., 1982). Também em parreirais na Ucrânia (CIS), obteve-se sucesso experimental na liberação e aclimatização de biótipos de G. occidentalis introduzidos do Canadá, EUAN e Austrália para o controle do ácaro rajado (Bol'Shakova \& Litvinov, 1991).

\section{- status quarentenário de $T$. urticae}

Apesar da espécie encontrar-se amplamente distribuída no mundo, é considerada uma praga de importância quarentenária para alguns países ou regiões (Holdeman, $1986^{48}$ citado por Kahan, 1989), sendo utilizadas medidas para evitar sua introdução ou a de novos biótipos da espécie.

\section{- biótipos de $T$. urticae resistentes a pesticidas}

Tem sido relatada a ocorrência de biótipos de $T$. urticae resistentes a pesticidas em muitos países onde a espécie sofre of sofreu intensa pressão de seleção por pesticidas (Tabela 9).

${ }^{48}$ HOLDEMAN, Q. (Ed.) Plant pests of phytosanitary significance to importing countries and states. 5.ed. Sacramento: California Department of Food and Agriculture, 1986. 
Há fortes evidências de resistência múltipla de $T$. urticae aos acaricidas fensom, tetradifom, dicofol, binapacril, organofosforados, carbamatos, quinometionatos, clordimeform e cihexatina (Cranham \& Helle, 1985).

Comumente, o desenvolvimento de resistência a um produto por populações de T. urticae causa resistência cruzada a outros produtos, do mesmo grupo químico ou de grupos próximos (Cranham \& Helle, 1985).

T. urticae é considerado a praga de controle mais dificil e custoso de folhagens de maçã em algumas regiões da América do Norte, o que se deve em grande parte ao potencial de desenvolver resistência a acaricidas (Croft \& Hoyt, $1983^{49}$ citado por Prokopy \& Croft, 1994).

Considerando os ítens acima, o potencial de biótipos de T. urticae em causar ou agravar problemas de ordem econômica no Brasil é elevado.

Tabela 9 - Ocorrência de populações de $T$. urticae resistentes a pesticidas por país.

\begin{tabular}{|c|c|c|c|}
\hline \multicolumn{2}{|c|}{ País - cultura } & Pesticidas & Fonte \\
\hline África do Sul & maçã & formetanato, clorfenamida & Myburgh \& Bosman (1970) \\
\hline Alemanha & $\begin{array}{l}\text { pepino } \\
\text { diversos }\end{array}$ & $\begin{array}{l}\text { acaricidas organofosforados, carbamatos e } \\
\text { formamidinas } \\
\text { dimetoato } \\
\text { dicofol } \\
\text { etiom, malatiom, diazinom, } \\
\text { paratiom,mevinfós, fosfamidom, demetom } \\
\text { metila, azinfós-etila, naled }\end{array}$ & $\begin{array}{l}\text { Richter \& Schulze (1990) } \\
\text { Otto (1988), Klunker (1973) } \\
\text { Otto (1988) } \\
\text { Kollner (1973) }\end{array}$ \\
\hline Austrália & $\begin{array}{l}\text { frut. decíduas. } \\
\text { maçã } \\
\text { hort. e ornam. }\end{array}$ & $\begin{array}{l}\text { clofentezine, óxido de fenbutatina } \\
\text { metidatiom, tetradifom, dicofol } \\
\text { óxido de fenbutatina, fluvalinato, } \\
\text { propargite }\end{array}$ & $\begin{array}{l}\text { Herron et al. (1997) } \\
\text { Unwin (1973) } \\
\text { Goodwin (1992) }\end{array}$ \\
\hline & $\begin{array}{l}\text { pêra } \\
\text { pêra e maçã } \\
\text { rosa }\end{array}$ & $\begin{array}{l}\text { óxido de fenbutatina } \\
\text { cihexatina } \\
\text { clofentezine, hexitiazox } \\
\text { bromopropilato, dicofol + tetradifom, }\end{array}$ & $\begin{array}{l}\text { Herron et al. (1994) } \\
\text { Bailey et al. (1984) } \\
\text { Edge \& James }(1983,1986) \\
\text { Gough (1990), } \\
\text { Herron et al. (1993); } \\
\text { Gough (1990) }\end{array}$ \\
\hline
\end{tabular}


dienochlor; enxofre; phorate

\begin{tabular}{|c|c|c|c|}
\hline \multirow{3}{*}{ Brasil } & algodão & monocrotofós & Chiavegato et al. (1983) \\
\hline & rosa & $\begin{array}{l}\text { cihexatina, dimetoato, mevinfós, } \\
\text { propargite, naled }\end{array}$ & Takematsu et al. (1994) \\
\hline & uva & $\begin{array}{l}\text { cihexatina, dimetoato, mevinfós, } \\
\text { propargite, naled }\end{array}$ & Souza Filho et al. (1994) \\
\hline Bulgária & casa -de - veget. & $\begin{array}{l}\text { alta resist. a dimetoato, mevinfós; dicofol } \\
\text { e Kilakar (acar.); fraca a moderada a } \\
\text { propargite, cihexatina, azociclotina, } \\
\text { amitraz }\end{array}$ & Darakchieva (1984) \\
\hline China & diversos & dicofol & Dong (1990) \\
\hline Coréia & $\begin{array}{l}\text { maçã } \\
\text { diversos }\end{array}$ & $\begin{array}{l}\text { dicofol, fenpiroximato, piridabem } \\
\text { dicofol } \\
\text { cihexatina, azociclotina, óxido de } \\
\text { fenbutatina, bifentrina, clofentezine, } \\
\text { hexitiazox, tetradifom, amitraz } \\
\text { demetom metila, propargite, } \\
\text { bromopropilato, benzoximato }\end{array}$ & $\begin{array}{l}\text { Cho et al. (1995) } \\
\text { Kim et al. (1995); } \\
\text { Song et al. (1995) } \\
\text { Kim et al. (1993); } \\
\text { Song et al. (1995) } \\
\text { Lee \& Yoo (1971); } \\
\text { Park et al. (1986) }\end{array}$ \\
\hline Egito & pêssego e maçã & $\begin{array}{l}\text { organofosforados e carbamatos } \\
\text { dimetoato e proclonol }\end{array}$ & $\begin{array}{l}\text { El Din (1992) } \\
\text { Guirguis et al. (1979) }\end{array}$ \\
\hline EUAN & $\begin{array}{l}\text { diversos } \\
\text { algodão } \\
\text { amêndoa } \\
\text { flores e soja } \\
\text { maçã } \\
\text { morango } \\
\text { pêra } \\
\text { frutiferas }\end{array}$ & $\begin{array}{l}\text { dicofol, bifentrina } \\
\text { dicofol, propargite } \\
\text { propargite } \\
\text { bifentrina } \\
\text { dicofol } \\
\text { cihexatina, formetanato } \\
\text { óxido de fenbutatina, cihexatina } \\
\text { cihexatina }\end{array}$ & $\begin{array}{l}\text { Fergusson Kolmes et al. } \\
\text { (1991);Kolmes et al. (1994) } \\
\text { Dennehy \& Granett (1984); } \\
\text { Dennehy et al. (1987) } \\
\text { Keena \& Granett (1987) } \\
\text { Ramdev et al. (1988) } \\
\text { Dennehy et al. (1988), } \\
\text { Rizzieri et al. (1988); } \\
\text { Miller et al. (1985) } \\
\text { Flexner et al. (1995),Hoyt et al. } \\
\text { (1985) } \\
\text { Tanigoshi \& Babcock (1990) }\end{array}$ \\
\hline Grécia & diversos & paratiom metila, metidatiom, metomil & Tsagkarokou et al. (1996) \\
\hline Holanda & rosa & tetradifom, dicofol, paratiom & $\begin{array}{l}\text { Helle \& Vrie (1974); Overmeer } \\
\text { et al. (1975) }\end{array}$ \\
\hline Hungria & diversos & dimetoato, amitraz, cloropropilato & $\begin{array}{l}\text { Hajnal \& Kerenyine-Nemestothy } \\
\text { (1985) }\end{array}$ \\
\hline
\end{tabular}




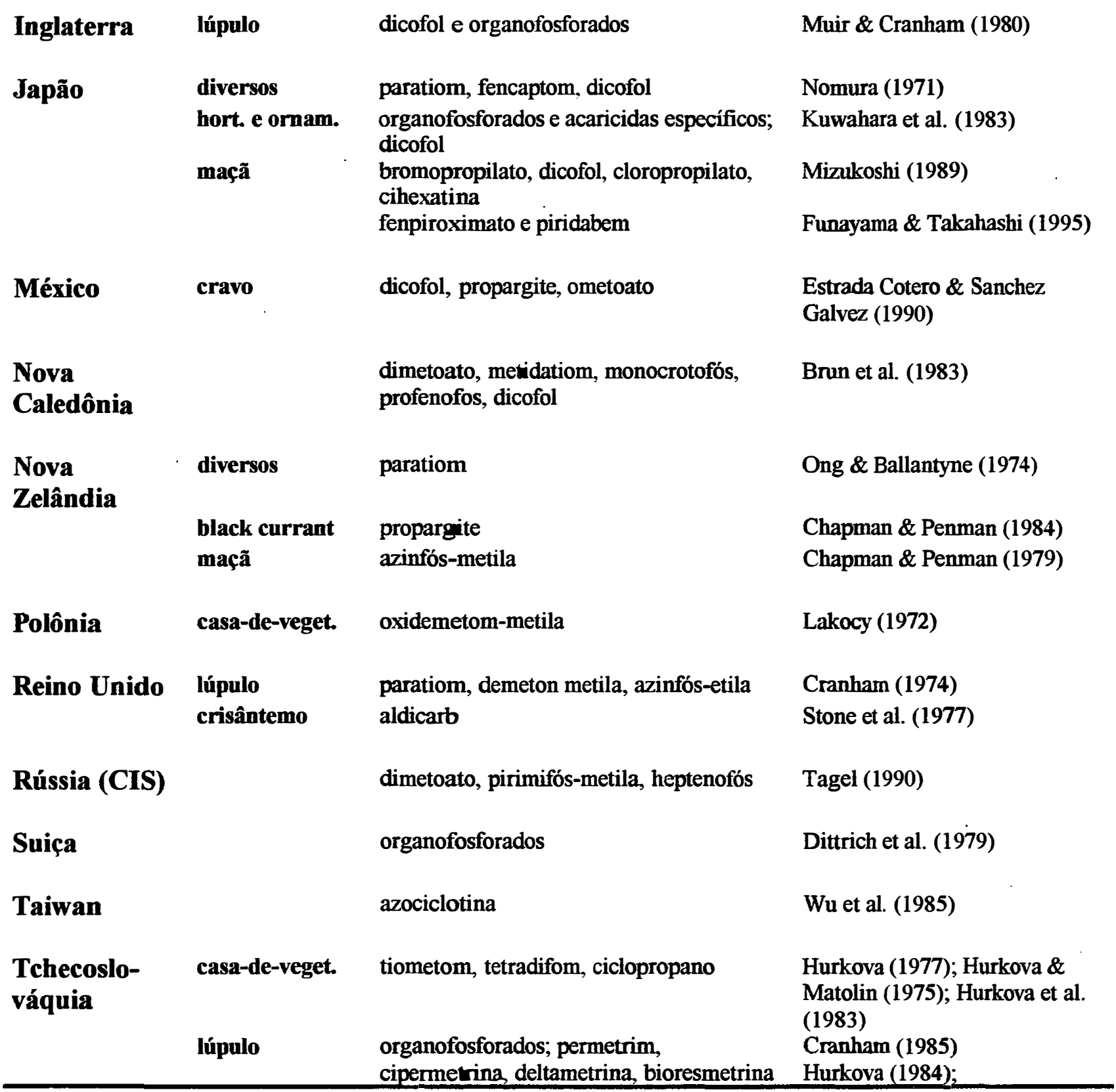


$\Rightarrow$ Potencial de Introdução - Alto

- possibilidades de infestação dos produtos importados nos países de origem

* presença e abundância da espécie nos países exportadores.

As principais vias de ingresso de biótipos de $T$. urticae resistentes a pesticidas no Brasil, considerando as referências encontradas sobre resistência a pesticidas em paises exportadores são: rosas e roseiras da Holanda e EUAN; maçãs da Nova Zelândia, Hungria e EUAN; pêras dos EUAN e China; morangos dos EUAN e Alemanha; mudas de videiras da Alemanha; ameixas dos EUAN e pêssegos da Grécia (Anexo B, Tabelas $11,12,1,2,15,4,8,6)$ (Brasil, 1996).

T. urticae é bastante abundante nos países exportadores onde são relatados biótipos resistentes a pesticidas. Em pomares de maçã, T. urticae é uma das espécies mais nocivas em diversas regiões produtoras, incluindo o leste e meio-oeste da América do Norte e sul e leste da Europa (Prokopy \& Croft, 1994; Van de Vrie, 1985a). T. urticae é a espécie mais comum em cultivos de morangos nos EUAN (Wysoki, 1985). A espécie atinge altos níveis populacionais em parreirais na Alemanha, onde é considerada uma das pragas mais nocivas à cultura (Englert, 1983; Englert \& Holz, 1989).

* volume, frequência e época das importações

$\mathrm{O}$ volume das importações de produtos potencialmente infestados por novos biótipos de T. urticae pelo Brasil é bastante grande.

Os EUAN é o segundo principal exportador de maçãs, pêras e pêssegos para o Brasil (Anexo B, Tabelas 1,2 e 6). A Holanda é o principal exportador de rosas para o Brasil e Holanda e EUAN representam o terceiro e quarto principais exportadores de roseiras, respectivamente (Anexo B, Tabelas 11 e 12). O principal exportador de ameixas e morangos para o Brasil é o EUAN (Anexo B, Tabelas 8 e 15). Grandes quantidades de mudas de videiras têm sido importadas da Alemanha para o Brasil (Anexo B, Tabela 4) (Brasil, 1996). 
As importações de frutas potencialmente infestadas por T. urticae dos EUAN têm sido bastante freqüentes. Foram importados 49 lotes de maçãs, 80 de pêras, 214 lotes de pêssegos, 182 lotes de ameixas e 87 lotes de morangos dos EUAN pelo Brasil de janeiro de 1992 a agosto de 1996. (Anexo B, Tabelas 1, 2, 6, 8, 15) (Brasil, 1996).

Em pomares de amêndoas na Califórnia, EUAN, densas populações de T. urticae ocorrem nos meses de verão, sendo que os níveis populacionais iniciam a aumentar de meados a final de junho (Hoy, 1985).

As importações de maçãs, pêras e morangos dos EUAN têm sido realizadas durante praticamente todo o ano, sendo que as de maçãs têm se concentrado nos meses de janeiro e fevereiro; as de pêras em agosto, janeiro e dezembro e as de morangos de março a junho (Anexo $\mathrm{C}$, Tabelas 1,2 e 10). As importações de pêssegos têm sido realizadas no período de abril a outubro, concentrando-se de junho a agosto e as de ameixas, de maio a outubro, concentrando-se em junho e julho (Anexo C, Tabelas 7 e 8 ). As importações de roseiras têm sido realizadas nos meses de maio, junho e dezembro, concentrando-se em maio e junho (Anexo C, Tabela 11) (Brasil, 1996).

Na Europa, T. urticae migra para as videiras no verão (Kassemeyer, 1996). Os picos populacionais certamente ocorrem nos meses de verão, que corresponde ao período de junho a setembro.

As importações de videiras da Alemanha têm sido realizadas nos meses de abril e dezembro (Anexo C, Tabela 4), enquanto as importações de rosas da Holanda têm sido realizadas no período de fevereiro a abril e em agosto e outubro, mas os maiores volumes têm sido importados em maio. Diferentemente, as importações de roseiras provenientes do mesmo país têm sido realizadas em junho (Anexo C, Tabelas 11 e 12); as importações de maçãs da Hungria têm sido realizadas em janeiro e novembro (Anexo C, Tabela 1); as importações de pêssegos da Grécia têm sido realizadas em maio, agosto-setembro e novembro, sendo que os maiores volumes foram importados em novembro (Anexo $\mathrm{C}$, Tabela 7); as importações de morangos da Alemanha têm sido realizadas em outubro (Anexo C, Tabela 10) (Brasil, 1996). 
Desta maneira, observa-se que grande parte das importações de pêras, morangos, pêssegos e ameixas dos EUAN; roseiras da Holanda e pêssegos da Grécia têm sido realizadas em épocas de alto risco de infestação.

Portanto, são muitas as possibilidades de infestação de produtos importados pelo Brasil por biótipos de $T$. urticae resistentes a pesticidas devido à abundância da espécie nos países exportadores, aos grandes volumes e à alta frequência das importações de produtos de países onde estes biótipos são relatados.

- possibilidades de sobrevivência da espécie às condições de transporte dos materiais.

Fêmeas adultas fertilizadas entram em diapausa no inverno (Hoy, 1985; Schruft, 1985; Van de Vrie, 1985a), sobrevivendo a baixas temperaturas neste período. As fềmeas hibernantes porventura associadas aos frutos provavelmente podem sobreviver às condições de transporte dos mesmos, que é realizado a baixas temperaturas e alta umidade relativa (Anexo E) (Brasil, 1994).

Ácaros desta espécie infestando mudas de videiras, rosas e roseiras apresentam grandes possibilidades de sobrevivência às condições de transporte dos mesmos.

Portanto, considera-se alta a possibilidade de sobrevivência de T. urticae às condições de tranporte dos produtos potencialmente infestados.

- possibilidades de detecção dos ácaros na ocasião da chegada de produtos infestados no Brasil.

\section{* localização na planta hospedeira}

Normalmente, $T$. urticae alimenta-se e forma colônias na superficie inferior das folhas, mas podem ser encontrados ácaros na superficie superior, quando as densidades populacionais são altas (Hoy, 1985). A oviposição é realizada na superficie inferior das folhas (Cranham, 1985). Também podem colonizar os frutos, alimentando-se destes, como observado em citros (Jeppson et al., 1975) e videiras (Schruft, 1985). As fềmeas 
adultas hibernam sob escamas ou em fendas da casca, na matéria orgânica do solo, em ervas daninhas ou sobre os frutos (Hoy, 1985; McMurtry, 1985; Schruft, 1985; Van de Vrie, 1985a).

Em avaliações realizadas em Taiwan, ácaros desta espécie foram encontrados em cachos de uvas em 8 dos 10 parreirais amostrados. Em média, 10\% dos cachos estavam infestados, entretanto, a densidade de ácaros nos cachos foi baixa $(0,63 \%)$ (Ho \& Chen, 1994). Em cachos de uvas os ácaros podem passar desapercebidos na região dos pecíolos das bagas.

Desta forma, para a detecção de T. urticae em mudas ou frutos, especialmente a de ovos e formas hibernantes, deve-se proceder uma detalhada inspeção.

\section{* dimensões/ coloração da espécie}

Todas as fases ativas do ácaro rajado apresentam coloração esverdeada. As fềmeas medem cerca de $370 \mu \mathrm{m}$ de comprimento e freqüentemente apresentam de uma a três manchas escuras no dorso e os machos medem $285 \mu \mathrm{m}$ de comprimento. Os ovos são esféricos e amarelados (Baker \& Tuttle, 1994; Flechtmann, 1985). As fềmeas hibernantes de T. urticae apresentam coloração laranja ou vermelha (Hoy, 1985; Schruft, 1985).

Portanto, para a deteç̧ão de T. urticae, especialmente a de ovos, que são muito pequenos e de coloração discreta, é necessária uma inspeção cuidadosa.

\section{* apresentação de sintomas em plantas/produtos infestados}

Os primeiros sintomas de infestação por $T$. urticae são manchas cloróticas e amarelecimento folhar causados pela alimentação dos ácaros na superficie inferior das folhas (Hoy, 1985; Schruft, 1985). A colonização de T. urticae em frutos pode resultar no bronzeamento dos frutos maduros (Jeppson et al., 1975).

Os ácaros desta espécie produzem teia abundantemente (McMurtry, 1985; Van de Vrie, 1985b), o que pode sinalizar a infestação. 
Consideram-se poucas as possibilidades de deteç̧ão de $T$. urticae na ocasião da chegada de produtos infestados no Brasil devido à suas reduzidas dimensões e coloração discreta, por poderem estar em locais protegidos nas plantas e pela carência de técnicos adequadamente treinados para deteç̧ão de ácaros em material vegetal no país.

\section{- disseminação de $T$. urticae através de material em trânsito.}

T. urticae têm sido interceptado em material vegetal em trânsito pelos serviços de quarentena vegetal de vários países. Ácaros desta espécie foram interceptados em pontos de entrada da Nova Zelândia em morangos provenientes da Inglaterra e em maçãs, rosas e orquídeas provenientes da Austrália (Manson, 1967). No Japão, T. urticae foi interceptado pelo "Yokohama Plant Protection Station" em: abóboras importadas dos EUAN e da Nova Zelândia; crisântemos de Taiwan, Holanda e Singapura; cravos dos EUAN, Taiwan e Sri Lanka; pêras da Coréia; rosas do Canadá, Malásia e Singapura; couve-de-bruxelas da Austrália e outras espécies omamentais da Malásia, Singapura, Nova Zelândia, Taiwan, EUAN e Reino Unido (Masaki, 1991; Kaneda, 1993). Na Holanda, T. urticae foi interceptado sobre bambus dos EUAN e Dianthus de Israel no período de 1992 a 1994 (Ackerman et al., 1994 e 1995). No Brasil, T. urticae foi detectado no Aeroporto Internacional de Guarulhos, São Paulo em roseiras importadas do Equador (Moraes ${ }^{50}$ ).

Para evitar a introdução ou reintrodução de $T$. urticae através da comercialização de frutos, muitos países importadores exigem a realização de tratamentos para eliminação destes ácaros. Por exemplo, frutos de kiwi importados da Nova Zelândia pelo Japão são fumigados na chegada do material devido à presença de $T$. urticae, o que representa um gasto estimado em \$ 4 a \$ 5 milhões por ano (Baker \& Cowley, 1989).

$\Rightarrow$ Potencial de estabelecimento - O potencial de estabelecimento de T. urticae no Brasil não será avaliado devido à espécie encontrar-se amplamente distribuida no país.

\footnotetext{
${ }^{50}$ MORAES, G. J. de (Pesquisador CNPq, Dept. Zoologia - Escola Superior de Agricultura "Luiz de Queiroz" - Piracicaba - SP - Brasil). Comunicação pessoal, 1997.
} 


\subsubsection{Considerações gerais}

Como pode-se observar na Tabela 10, 6 espécies de ácaros - A. schelchtendali, B. chilensis, E. carpini, T. mcdanieli, T. pacificus e T. turkestani - apresentam alto potencial de importância econômica, introdução e estabelecimento no Brasil. Estas espécies são de importância quarentenária para o Brasil, sendo necessária a implementação de medidas para evitar sua introdução no país. Para estas espécies, dispõe-se de dados suficientes para justificar seu status quarentenário no país.

Devido à maioria destas espécies serem polífagas, são várias as vias de ingresso no país, podendo ser introduzidas através de diversos tipos de frutos e de rosas, além de frutos e mudas de macieiras e videiras. Observa-se que os estados para os quais têm sido destinados os produtos potencialmente infestados são importantes produtores das culturas ameaçadas, isto é, que são severamente infestadas pelos ácaros nos países onde ocorrem. Além de danos à cultura da uva, várias destas espécies podem causar sérios danos a outras culturas frutiferas e mesmo a culturas extensivas de grande importância econômica no país, como no caso de $T$. pacificus e $T$. turkestani (Tabela 11). Portanto, considerando as atuais vias de ingresso destas pragas no país, é necessário prosseguir a ARP, selecionando as medidas mais eficientes para minimizar os riscos de introdução e estabelecimento destas pragas no país.

Comparando as espécies de ácaros atualmente consideradas pragas de importância quarentenária para o Brasil e aquelas associadas a uva e maçã cuja importância quarentenária foi avaliada no trabalho, verifica-se que realmente é necessária uma atualização e revisão da lista vigente. Somente uma das espécies avaliada como de importância quarentenária para o país está presente na atual lista de pragas de importância quarentenária - T. pacificus. Para a outra espécie associada a frutíferas atualmente considerada quarentenária para o Brasil, B. lewisi, não foram encontrados dados suficientes para justificar seu status quarentenário.

Duas espécies de ácaros-praga, $T$. urticae e $P$. ulmi, que já são assinaladas no Brasil e apresentam biótipos distintos em outros países, apresentam alto potencial de importância econômica e introdução no país (Tabela 10). Até recentemente, era difícil 
argumentar que pragas amplamente distribuidas no país deveriam ser consideradas de importância quarentenária. Entretanto, já é aceito que biótipos distintos de uma praga que já ocorre em uma região pode apresentar importância quarentenária para um país ou região, como citado por Baker et al. (1993). Para o Brasil, onde não têm sido relatados problemas sérios com populações destas espécies resistentes a pesticidas, é bastante importante adotar medidas quarentenárias para evitar introduções de biótipos resistentes no país. Também é importante a adoção de medidas para evitar a introdução de biótipos de $P$. ulmi que infestem videiras, já que no Brasil esta espécie têm causado problemas somente em macieiras. 
Tabela 10. Avaliação do potencial de importância econômica, introdução e estabelecimento no Brasil de espécies de ácaros associados às culturas de uva e maçã.

\begin{tabular}{lccc}
\hline Espécie & $\begin{array}{c}\text { Potencial de } \\
\text { import. econômica }\end{array}$ & $\begin{array}{c}\text { Potencial de } \\
\text { introducão }\end{array}$ & $\begin{array}{c}\text { Potencial de } \\
\text { estabelecimento }\end{array}$ \\
\hline Aculus schlechtendali & Alto & Alto & Alto \\
\hline Amphytetranychus viennensis & Alto & Médio & Médio \\
\hline Brevipalpus chilensis & Alto & Alto & Alto \\
\hline Brevipalpus lewisi & Médio & Médio & Alto \\
\hline Bryobia rubrioculus & Médio & Médio & Médio \\
\hline Cenopalpus pulcher & Médio & Alto & Médio \\
\hline Eotetranychus carpini & Alto & Alto & Alto \\
\hline Eotetranychus willamettei & Médio & Alto & Alto \\
\hline Oligonychus vitis & Baixo & -- & -- \\
\hline Panonychus ulmi & Alto & Alto & --- \\
\hline Tetranychus canadensis & Baixo & -- & -- \\
\hline Tetranychus mcdanieli & Alto & Alto & Alto \\
\hline Tetranychus pacificus & Alto & Alto & Alto \\
\hline Tetranychus schoenei & Baixo & --- \\
\hline Tetranychus turkestani & Alto & Alto & Alto \\
\hline Tetranychus urticae & Alto & Alto & -- \\
\hline
\end{tabular}

-- não foi avaliado 


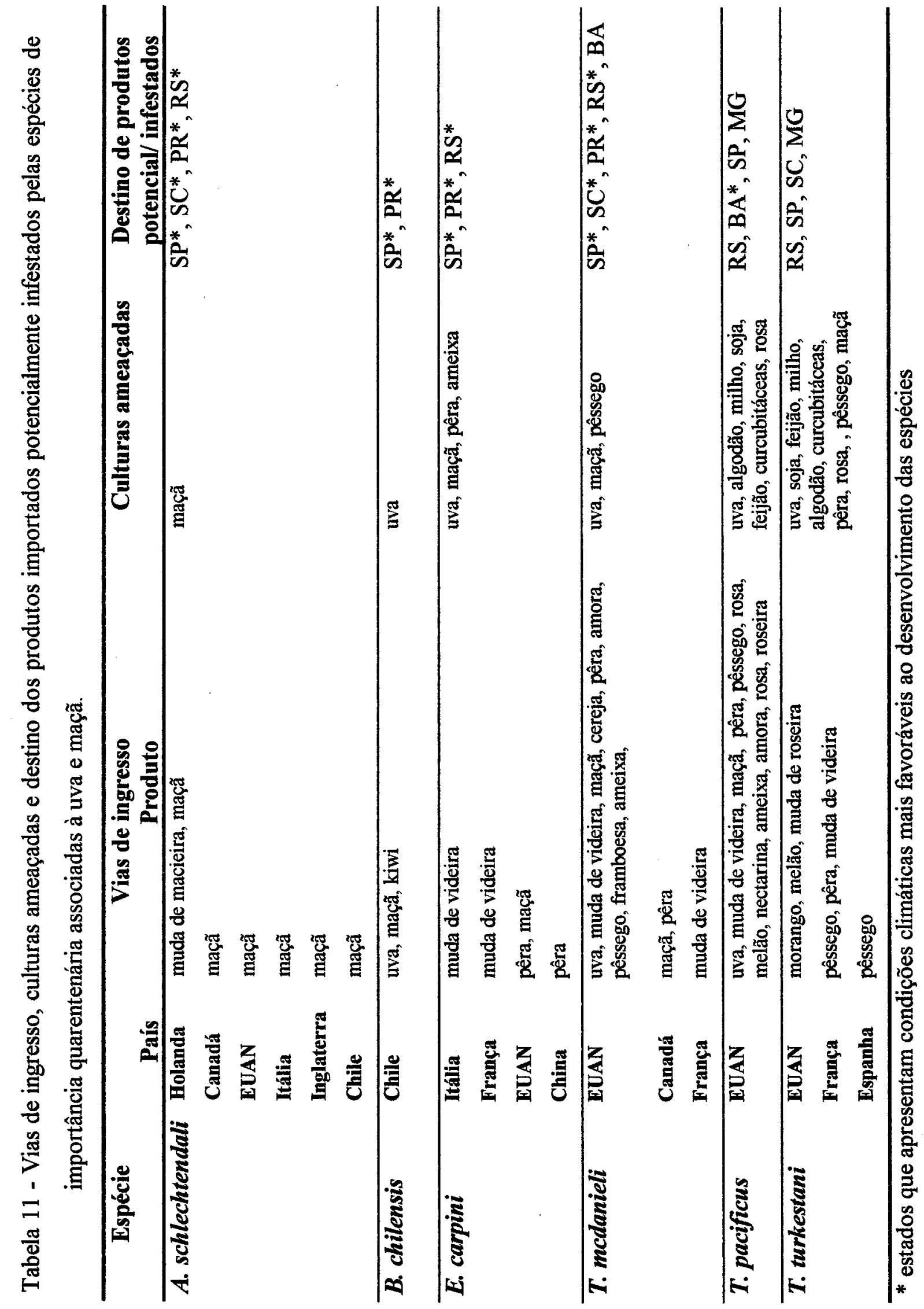


As espécies que apresentam médio ou baixo potencial de importância econômica podem não estar causando problemas sérios nos países onde ocorrem devido à ação de inimigos naturais nestes. Caso a espécie seja introduzida no Brasil, na ausência destes inimigos naturais, poderá vir a causar problemas sérios.

Como exemplo desta questão temos a introdução do ácaro verde da mandioca, Mononychellus tanajoa (Bondar), na África. Em grande parte da América do Sul, o continente de origem deste ácaro, mais especificamente no Brasil, os danos causados à cultura da mandioca não eram muito severos e, quando introduzido acidentalmente na África, tornou-se uma das pragas mais sérias da cultura, levando a perdas significativas na produção (Herren \& Neuenschwander, 1991; Janssen \& Yaninek, 1993). Isto ocorreu devido à ausência de inimigos naturais eficientes no novo continente (Moraes ${ }^{51}$ ).

Entretanto, acordos internacionais estabelecem que uma espécie somente pode ser listada como praga quarentenária quando se dispõe de argumentos para isto. A primeira justificativa que dever ser apresentada é a importância econômica da espécie nos países onde é assinalada. É necessário reavaliar este conceito tendo como base casos de introduções de pragas como M. tanajoa na África.

Algumas das espécies que apresentaram médio ou baixo potencial de importância econômica foram assim avaliadas devido a poucas informações sobre danos causados nos seus países de origem. Seria interessante solicitar informações sobre o status da espécies a especialistas nos países onde ocorre para assegurar que não vêm causando problemas nestes países. Corre-se o risco de não estar encontrando informações sobre as espécies por não ter acesso à bibliografia destes países.

O trabalho foi conduzido utilizando dados de importação de produtos vegetais pelo Brasil de janeiro de 1992 a agosto de 1996. Caso seja iniciada importação de produtos de países com os quais não havia comercialização anteriormente, ou se intensifique a comercialização com alguns deles, deve-se avaliar novamente o potencial de introdução de algumas das espécies.

${ }^{\text {SI }}$ MORAES, G. J. de (Pesquisador CNPq, Dept. Zoologia - Escola Superior de Agricultura "Luiz de Queiroz" - Piracicaba - SP - Brasil). Comunicação pessoal, 1997. 
Isto se evidencia no caso de $A$. viennensis, espécie que apresenta alto potencial de importância econômica para o país, mas médio potencial de introdução, devido aos volumes de importação de produtos potencialmente infestados serem pequenos e à baixa freqüência das importações. Também pode-se citar Tetranychus kanzawai Kishida, espécie associada a maçã e uva, de grande importância econômica no Japão, Filipinas e Taiwan (Ashihara, 1995; Ho et al., 1995; Villacarlos \& Vasquez, 1988), países que atualmente não são exportadores de produtos potencialmente infestados por esta espécie para o Brasil (Brasil, 1996; Flechtmann ${ }^{52}$, Jeppson et al., 1975).

Qualquer nova informação sobre as espécies deve ser incorporada à sua ARP, pois, assim como a importação de produtos de países distintos, pode alterar a avaliação realizada.

${ }^{52}$ FLECHTMANN, C. H. W. (Pesquisador CNPq, Depto. Zoologia, ESALQ, Universidade de São Paulo, Piracicaba, SP). Comunicação pessoal, 1997. 


\subsection{CONCLUSÕES}

- É necessário revisar a lista vigente de pragas de importância quarentenária para o Brasil, no que se refere a ácaros.

- Seis espécies de ácaros associados às culturas de uva e maçã (A. schlechtendali, B. chilensis, E. carpini, T. mcdanieli, T. pacificus e T. turkestani) são de importância quarentenária para o Brasil, devendo-se adotar medidas quarentenárias para evitar sua introdução no país.

- Além de evitar a introdução e estabelecimento de ácaros-praga não assinalados no Brasil, é extremamente importante evitar introduções de biótipos de $P$. ulmi e T. urticae resistentes a pesticidas e de $P . u l m i$ que infestem videiras. . 


\section{4. disSEMINAÇÃo de ÁCAROS FITÓFAGOS ATRAVÉS DE MATERIAL PARA PROPAGaÇÃo VEGETATIVA de Arachis pintoi (Krap. \& Greg.) (FABACEAE).}

\subsection{INTRODUÇÃO}

Ácaros fitófagos podem ser veiculados por uma grande variedade de materiais vegetais, ser introduzidos em áreas isentas e causar sérios problemas a culturas importantes.

Arachis pintoi (Krapovickas \& Gregory) (Fabaceae) é uma leguminosa perene originária do Brasil, que vem sendo utilizada principalmente como fixadora de nitrogênio atmosférico em pastagens nas savanas tropicais. Devido às suas características agronômicas promissoras, esta leguminosa tem sido amplamente distribuida no país e exportada para diversos países da América Latina e Austrália.

A propagação de $A$. pintoi pode ser realizada por meio de sementes ou estolhos. Quando a propagação é realizada por meio de sementes, esta leguminosa se estabelece mais rapidamente que quando se utilizam estolhos. Entretanto, é comumente propagada por meio de estolhos devido às dificuldades de colheita das sementes, que se formam no solo (Fisher \& Cruz, 1994; Cardozo \& Ferguson, 1995).

Muito pouco se sabe sobre os problemas fitossanitários de $A$. pintoi e, conseqüentemente, das pragas que podem estar sendo disseminadas através de material de propagação vegetativa desta leguminosa.

O objetivo deste trabalho foi avaliar os ácaros fitófagos associados a $A$. pintoi e alertar quanto à possibilidade de veiculação de ácaros através de estolhos desta leguminosa, que poderiam ser dispersos a outras regiões no Brasil ou a outros países. 


\subsection{REVISÃO DE LITERATURA}

\subsubsection{Utilização de $A$. pintoi}

A. pintoi é uma leguminosa, originária do estado da Bahia - Brasil (Grof, $1984^{1}$ in Cardozo \& Ferguson,1995), que vem sendo exportada para a Austrália e diversos países da América Latina, principalmente Colômbia, Costa Rica e México (Asakawa \& Ramirez, 1989; Vilarreal \& Chavez, 1991; Gomez et al., 1994; Jones, 1993; Cook et al., 1990). Nestes paises, as características agronômicas da espécie vêm sendo avaliadas e ,em alguns, ela já está sendo utilizada.

A. pintoi é utilizado principalmente como fixador de nitrogênio em pastagens, onde pode ser associado a diversas gramíneas, principalmente Brachiaria. Em associação de Brachiaria decumbens com $A$. pintoi na Colômbia, verificou-se que mais de $60 \%$ do nitrogênio encontrado na leguminosa foi fixado da atmosfera (Suárez-Vásquez et al., 1992). A. pintoi é considerada uma leguminosa de alta qualidade, bem aceita pelo gado durante todo o ano e bem adaptada a pisoteio pesado nas savanas (Lascano \& Thomas, 1988; Grof, 1985).

Além da utilização como forrageira em pastagens, $A$. pintoi tem mostrado alto potencial como cobertura em culturas de café, banana, dendê, e macadâmia, na Colômbia

1 GROF, B. Arachis pintoi: una leguminosa forrajera promisoria para los LLanos Orientalis de Colombia. Pasturas Tropicales - Boletín Informativo, n.7, p.1-4, 1984. 
(De La Cruz et al, 1994; Suárez-Vásquez et al.,1992). Na Austrália, bons resultados foram obtidos quando se avaliou a utilização de $A$. pintoi como cobertura perene em pomares (Firth \& Wilson, 1995; Firth, 1993). Cardozo \& Ferguson (1995) relataram que A. pintoi também pode ser associado a cultivos de milho e feijão sem interferir na produtividade destas culturas.

O plantio de $A$. pintoi também pode ser utilizado como medida para reduzir populações de nematóides em culturas. A formação de galhas em raizes de tomateiro foi reduzida em quase $50 \%$ quando associou-se a leguminosa à cultura (Domingues Valenzuela, et al., 1990).

\subsubsection{Problemas fitossanitários de $A$. pintoi.}

São poucas as informações sobre os problemas fitossanitários de $A$. pintoi.

$\mathrm{Na}$ Colômbia, um vírus filamentoso foi isolado de plantas que apresentavam sintomas de manchas anelares nas folhas e isolados induziram os mesmos sintomas quando inoculados mecanicamente (Morales et al., 1991).

Alguns registros da ocorrência de ácaros fitófagos em $A$. pintoi foram realizados na Costa Rica. Foram detectados Tetranychus urticae Koch, 1836 e Brevipalpus sp. em folhas de $A$. pintoi utilizado como cobertura em cultivo de pupunha (Bactris gasipaes Kunth.). Também observou-se um ataque severo de Oligonychus gossypii (Zacher, 1921) na haste e na superficie inferior de folhas de $A$. pintoi utilizado como planta ornamental em jardins; na haste das plantas observaram-se pontos brancos, que se transformaram em mosqueados amarelados com o avanço da infestação, e a superficie inferior das folhas infestadas apresentou uma coloração variável entre amarelo e marrom (Vargas et al., 1996). 


\subsection{METODOLOGIA}

Amostras de plantas de $A$. pintoi foram coletadas no campo experimental do Centro Nacional de Pesquisa Agropecuária do Cerrado - CPAC - EMBRAPA - Planaltina - DF.

Em laboratório, as plantas coletadas foram cuidadosamente examinadas ao estereoscópio, utilizando um aumento igual ou superior a 30 vezes, para detecção de ácaros fitófagos. A inspeção acarológica foi realizada examinando-se a superficie dos tecidos, dando atenção especial aos locais geralmente utilizados como abrigo por ácaros, isto é, regiões próximas a nervuras, ranhuras no caule, escamas das gemas, ou à região que circunda os pecíolos.

Os ácaros detectados foram montados em lâminas microscópicas, em meio de Hoyer, exceto para eriofíideos, que foram montados em meio modificado de Berlese ao qual é adicionado iodo. Após a montagem das lâminas, estas permaneceram em estufa a $60^{\circ} \mathrm{C}$ por aproximadamente 5 dias, sendo então lutadas com esmalte incolor.

A identificação dos ácaros detectados foi realizada em microscópio de contraste de fase, consultando-se a bibliografia pertinente.

As espécies identificadas como novas foram descritas. Os desenhos foram realizados com o auxílio de uma câmara clara acoplada ao microscópio de contraste de fase. As medições dos ácaros eriofídeos foram realizadas a um aumento de 100 vezes.

Colônias de ácaros do gênero Tetranychus presentes nas amostras foram transferidas, em laboratório, para plantas de Arachis prostata Benth, uma leguminosa freqüentemente associada com gramíneas em jardins, e de Arachis hypogeae L., amendoim. Observou-se o desenvolvimento das colônias dos ácaros nestes hospedeiros. 


\subsection{RESULTADOS E DISCUSSÃO}

Foram detectadas e descritas ${ }^{2}$ duas espécies novas de ácaros fitófagos nas amostras de $A$. pintoi, uma pertencente ao gênero Tetranychus, da familia Tetranychidae, e outra ao gênero Aceria, da família Eriophyidae.

Tetranychus ogmophallos Ferreira \& Flechtmann, 1997 (Figuras 4.1-14)

\section{Diagnose}

As fềmeas apresentam as estrias entre as setas dorsais $e_{1}$ e $f_{1}$ em padrão de diamante; o par de setas proximais à seta duplex na perna I é alinhado com a maioria das outras setas proximais; unhas empodiais com um esporão dorso-mediano bem desenvolvido; quetotaxia das pernas única.

Nos machos, o botão do edeago apresenta as angulações anterior e posterior pequenas; quando não cuidadosamente focalizado a um aumento de $500 \mathrm{x}$, assemelha-se ao edeago de Tetranychus evansi Baker \& Pritchard, 1960; entretanto, sob um aumento de 1000 vezes, observa-se que o eixo do botão é quase paralelo ao eixo principal; a angulação anterior (proximal) é curta e agudamente angulada e a posterior é consideravelmente mais longa e agudamente angulada; a linha dorsal do botão é quase plana, apenas levemente arqueada. A haste do edeago é posterior e longitudinalmente (verticalmente) sulcada e do

2 FERREIRA, D. N. M.; FLECHTMANN, C. H. W. Two new phytophagous mites (Acari: Tetranychidae, Eriophyidae) from Arachis pintoi from Brazil. Systematic and Applied Acarology, v.2, p.181-188, 1997. 
fundo do sulco projeta-se uma estrutura em forma de espinho (côncava ?), quase tão longa quanto a largura da haste na junção com o botão; esta estrutura é direcionada posteriormente e para baixo em um ângulo de cerca de $45^{\circ}$ com o eixo do caule principal. Fêmea . Medidas em micrômetros do alótipo, com as variações de 10 parátipos.

Estilóforo arredondado anteriormente; peritremas encurvados distalmente. Estrias prodorsais longitudinais; estrias opistossomais transversas mas em padrão de diamante entre as setas $e_{1}$ e $f_{1}$. Setas dorsais do corpo longas, extendendo-se para trás das bases das próximas duas fileiras de setas. Área pré-genital com estrias longitudinais, cerca de metade delas são linhas pontilhadas; epiginio com estrias transversas, um pouco arqueadas. Espinerete ("sensilo terminal" do tarso do palpo) robusto, um pouco mais longo que uma vez e meia sua largura. Tarso I com uma seta sensorial e três setas táteis em linha circumsegmental com a seta duplex proximal. Tíbia I com 9, ocasionalmente 10, setas táteis e uma sensorial (solenídio). Empódios I-IV com esporões dorsomedianos bem desenvolvidos.

Quetotaxia das pernas, da coxa para o tarso:

$$
\begin{array}{ll}
\text { I } & 2-1-10-5-9[10](1)-12(2)+2 \text { duplexes } \\
\text { II } & 2-1-6-5-7[6]-13(1)+1 \text { duplex } \\
\text { III } & 1-1-4-4-6-9(1) \\
\text { IV } & 1-1-4-4-7-10(1)
\end{array}
$$

Obs.: número de setas táteis seguido de [ ], significa contagem alternativa (mais rara); e de ( ), significa número de setas sensoriais.

Comprimento do corpo, incluindo gnatossoma 450 (405 - 480); largura 243 (217 $-247), n=10$.

Macho. Medidas em micrômetros do holótipo seguido das variações em 10 parátipos.

Menores que as fềmeas. Empódio I dividido em três lâminas (placas), com um esporão dorsomediano robusto, bem desenvolvido. Tarso I com duas setas sensoriais (solenídio) e duas setas táteis proximais à seta duplex proximal e uma seta tátil em linha circumsegmental com a seta duplex proximal. Tíbia I com quatro (às vezes três) setas 
sensoriais e nove (às vezes oito) setas táteis. Fiandeira ("sensilo terminal" do tarso do palpo) aproximadamente duas vezes e meia tão largo quanto longo. Edeago curvado dorsalmente, cabeça ou botão com curta angulação anterior aguda e maior angulação posterior aguda; linha dorsal do botão apenas levemente arqueada; haste do edeago médio-posteriormente e longitudinalmente (verticalmente) sulcada; do fundo do sulco projeta-se uma estrutura em forma de espinho, tão longa quanto a largura da haste na junção com o botão, direcionada póstero-ventralmente a $45^{\circ}$.

Quetotaxia das pernas, da coxa para o tarso:

$$
\begin{array}{ll}
\text { I } & 2-1-10(9)-5-9[8](4[3])-13(3)+2 \text { duplexes } \\
\text { II } & 2-1-6-5-7-13[12](1)+1 \text { duplex } \\
\text { III } & 1-1-4-4-6-9(1) \\
\text { IV } & 1-1-4-4-7-10[9](1)
\end{array}
$$

Comprimento do corpo, incluindo gnatossoma 450 (405 - 480); largura 243 (217 $-247), \mathrm{n}=10$.

Material Tipo. Holótipo macho, 39 parátipos machos; 70 parátipos fềmeas, de Arachis pintoi (Krap. \& Greg.) (Fabaceae), em 33 preparações microscópicas, coletados por DNMF, no Centro de Pesquisas Agropecuárias do Cerrado, EMBRAPA, Planaltina, DF, Brasília, Brasil, em 08 de dezembro de 1995. Material depositado na coleção do Departamento de Zoologia, Universidade de São Paulo - ESALQ, Piracicaba, São Paulo, Brasil.

Etimologia. A designação específica, ogmophallos, é derivada do masculino Grego ogmos $=$ sulco e do masculino Grego phallos $=$ pênis, edeago, referindo-se ao sulco médio-longitudinal do edeago. Tetranychus também é masculino.

Observações Biológicas. As fềmeas de $T$. ogmophallos são de coloração vermelhacarmim escuras. Formam grandes colônias em ambas superficies folhares, causando clorose e queda prematura das folhas; observou-se formação de densa e abundante teia sobre as plantas. 
Estes ácaros foram facilmente transferidos para plantas de $A$. prostrata, uma leguminosa freqüentemente associada a gramíneas em jardins; e para amendoim, $A$. hypogeae. Em ambas, colônias de $T$. ogmophallos desenvolveram-se bem; as plantas de amendoim mantidas em laboratório sofreram danos severos e morreram. 

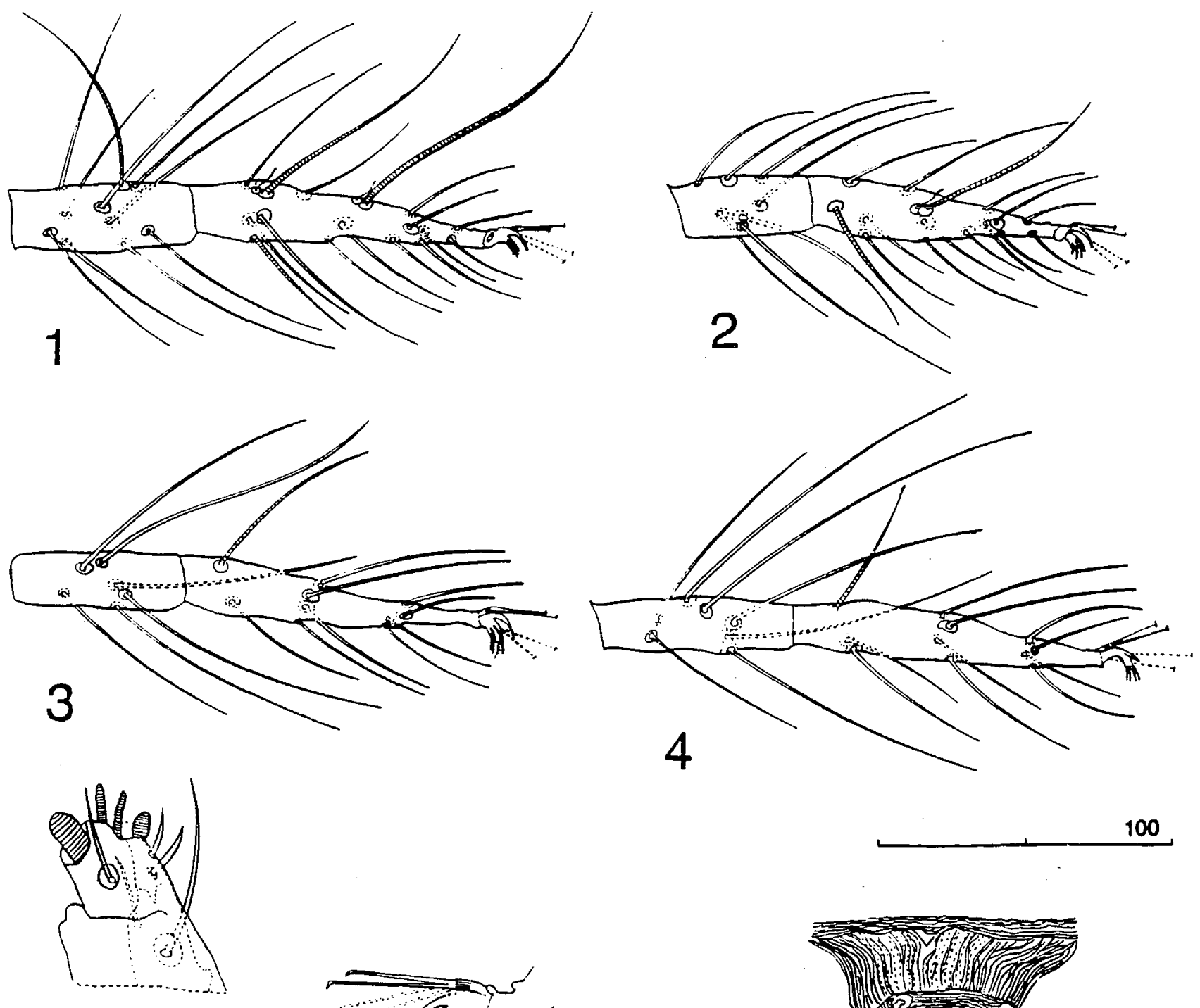

5
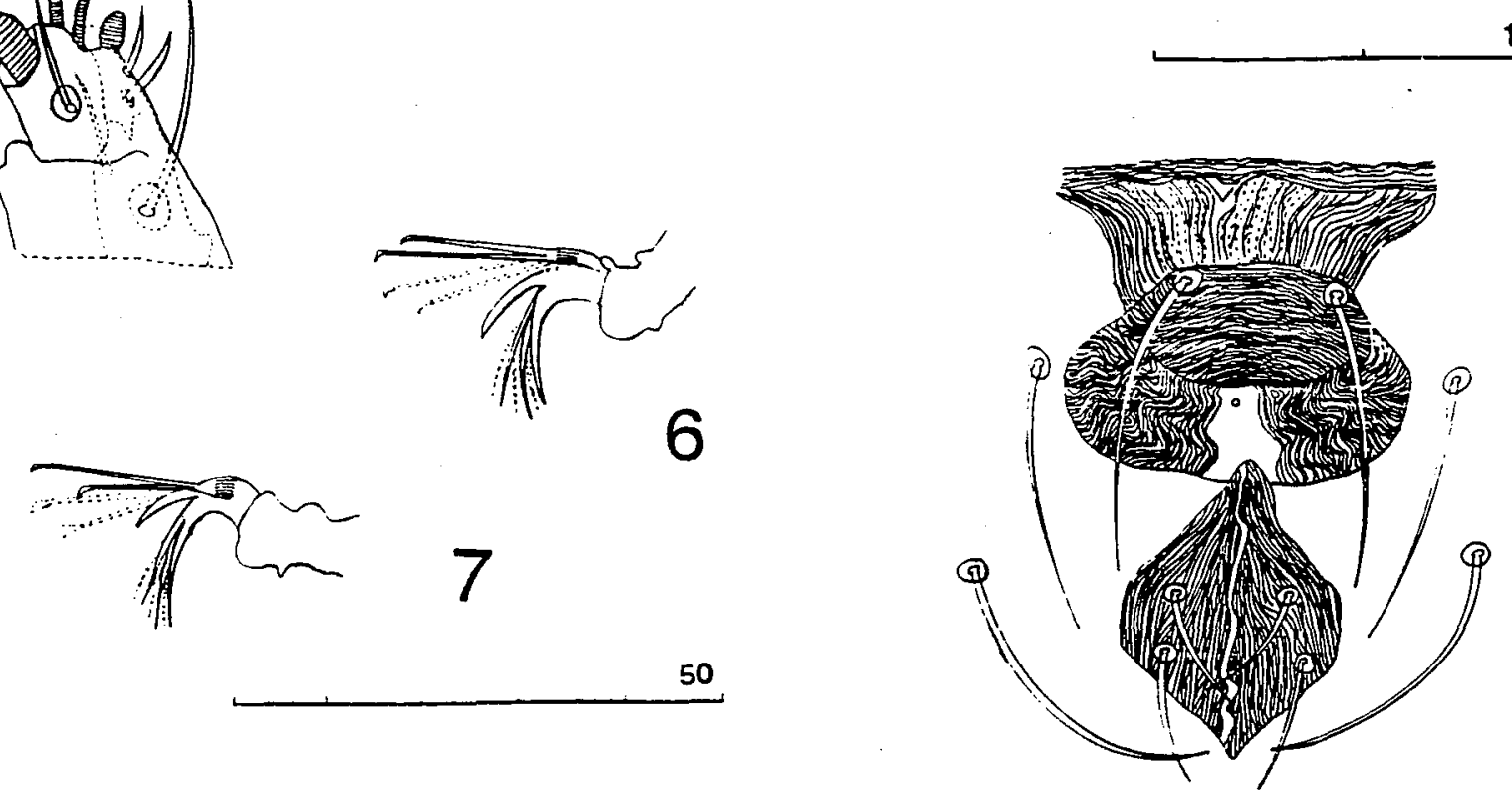

Figuras 4.1-8 - Tetranychus ogmophallos Ferreira \& Flechtmann, fềmea

1- tarso e tíbia I; 2- tarso e tíbia II; 3- tarso e tíbia III; 4- tarso e tíbia IV;

5- tarso palpal; 6-apêndices tarsais I; 7-apêndices tarsais II; 8- área gênito-anal 

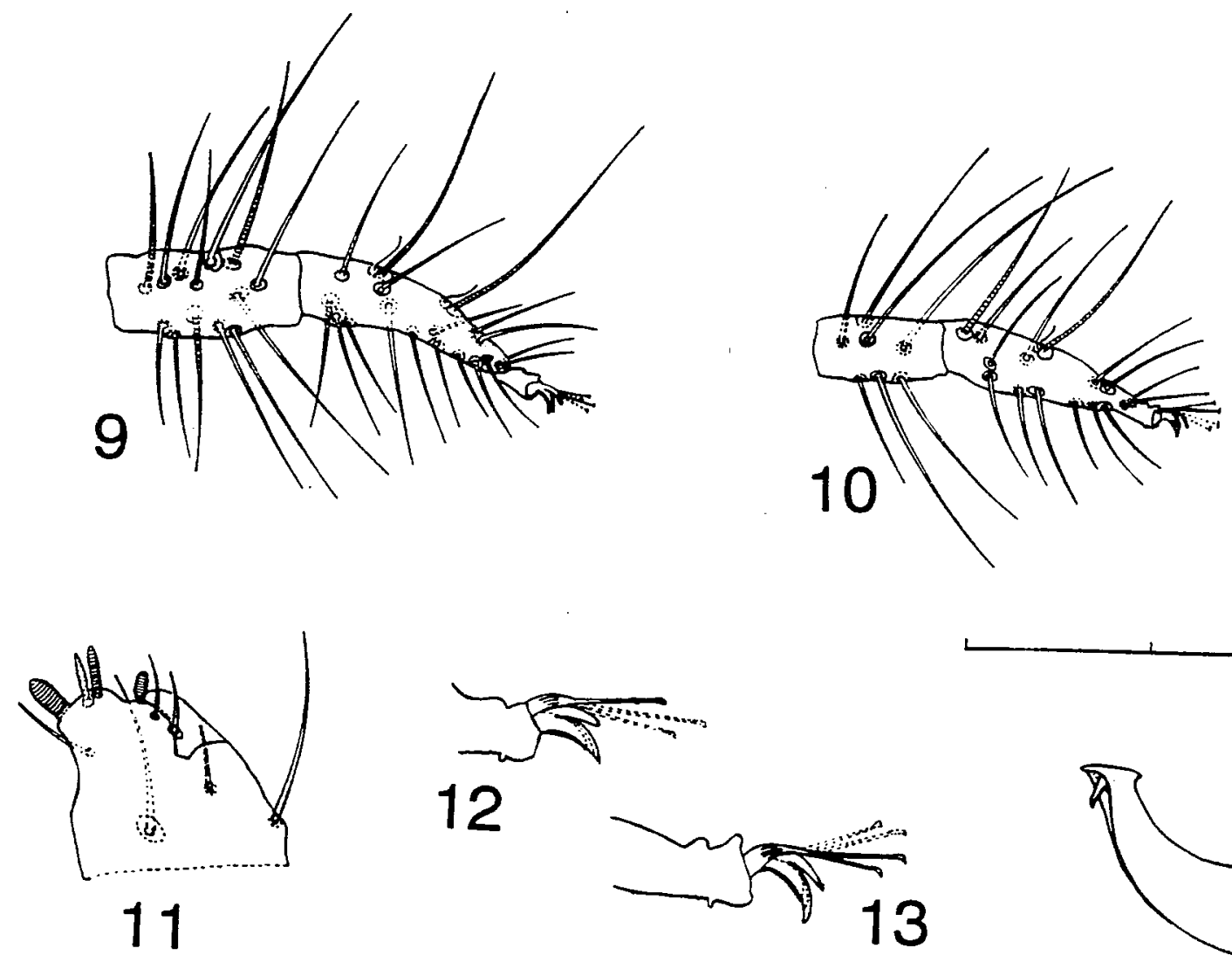

50

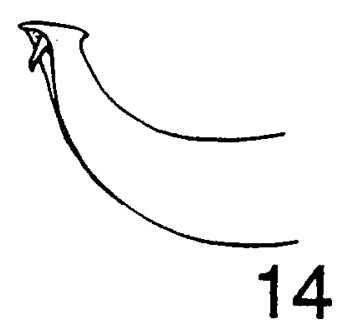

Figuras 4.9-14 - Tetranychus ogmophallos Ferreira \& Flechtmann, macho

9- tarso e tíbia I; 10- tarso e tibia II; 11-tarso palpal; 12-apêndices tarsais I; 13 - apêndices tarsais II; 14 - edeago (ampliado). 
Aceria pintoi Ferreira \& Flechtmann, 1997 (Figuras 4.15-22).

Diagnose. $A$. pintoi é o primeiro eriofídeo a ser descrito de uma planta do gênero Arachis ou de qualquer outra Fabaceae da tribo Aeschinomenae, que inclue Arachis (Amrine \& Stasny, 1994). Esta espécie difere de todas as outras Aceria descritas de Fabaceae; daquelas descritas de Acacia spp., difere pelo lobo ântero-mediano largo e curto, o qual é triangular e agudo em $A$. aechmaspus $\mathrm{S}$. Meyer (1990b), A. liopeltus $\mathrm{S}$. Meyer (1990b), A. spinosciae S. Meyer (1990b), A. nelensis S. Meyer (1990b), A. albidae S. Meyer (1990b), A. skukuzae S. Meyer (1990b), A. acacifloris S. Meyer (1990b), A. karrooi S. Meyer (1990b), A. transvaalensis S. Meyer (1990b), A. dictynus S. Meyer (1990b), A. leptum S. Meyer (1990b), A. bosforus S. Meyer (1990b), A. potamius S. Meyer (1990b), A. burnleya Keifer (1965), A. amnicolus S. Meyer (1990b), A. niloticae S. Meyer (1990b), A. calidensis S. Meyer (1990b) e de $A$. giraffae S. Meyer (1990a); pelas linhas longitudinais do escudo dorsal bem definidas difere de $A$. falciformis Keifer (1969a) e de A. rosas-costae Keifer (1952), que apresentam as linhas do escudo tênues ou obsoletas; de $A$. calilupini Keifer (1946) pelo empódio com 6 raios (7 raios em calilupini); de $A$. geoffrae Keifer (1969b), que apresenta um padrão de escudo confuso, consistindo de linhas de traços tênues, e empódios com 5 raios, e, de $A$. dalae Keifer (1960), que tem 14 linhas longitudinais na cobertura genital (8 em $A$. pintoi); e de $A$. boissieri Roivainen (1953), que apresenta as setas do escudo dorsal longas (22-25 $\mu \mathrm{m}$ ) (mais curtas em $A$. pintoi, de 18-19 $\mu \mathrm{m}$ ) e é uma espécie muito menor, de 125-140 $\mu \mathrm{m}$ de comprimento (A. pintoi mede 160-229 $\mu \mathrm{m}$ de comprimento).

Fêmea. Medidas em micrômetros; holótipo com a variação de 9 parátipos .

Alongada, vermiforme, 214 (179-229) de comprimento do corpo; 53 (55-65) de largura. Gnatossoma 29 (26-28) de comprimento. comprimento da seta basal 3 (2-3); seta anti-apical com 5 (4-5) de comprimento; quelíceras de 19 (18-30) de comprimentonto. Escudo prodorsal 28 (27-31) de comprimento, 47 (44-62) de largura, linhas medianas extendendo-se até um pouco mais de um terço do escudo; linhas admedianas extendem- 
se por todo o comprimento do escudo e conectam-se posteriormente através de um largo ângulo V; segundas e terceiras linhas submedianas presentes. Setas do escudo prodorsal sobre tubérculos na borda posterior do escudo, separados em 22 (18-24), de 18 (18-19) de comprimento, extendendo-se para trás, até o oitavo anel. Pernas com todas as setas normais presentes. Pernas I 31 (29-33); fềmur 8 (8-10), seta do fềmur 10 (7-10); genu 5 (4-6), seta do genu 24 (22-25); tíbia 7 (5-8), seta da tíbia 5 (6-7); tarso 6 (6-8), seta lateral 21 (19-24), seta dorsal 14 (11-17), seta mesal 4 (4-7), solenídio 8 (7-9), empódio 7 (6-8) de comprimento com 6 raios. Pernas II 31 (27-30); fềmur 8 (8-9), seta do fềmur 9 (8-10); genu 4 (4-4), seta do genu 6 (8-10); tíbia 6 (5-6); tarso 5 (5-7), seta lateral 22 (22-25), seta dorsal 5 (5-6), seta mesal 4 (4-5), solenídio 8 (8-9), empódio 7 (7-7) de comprimento com 6 raios. Coxa, seta coxal 1, 10 (6-7) e separadas em 14 (13-16); seta coxal 2, 14 (14-15) e separadas em 11 (10-11); seta coxal 3, 37 (31-37) e separadas em 24 (23-26). Coxas com poucos grânulos. Linha esternal com 4 (2-4) de comprimento. Região coxiesternal com 6 (4-6) anéis, microtuberculados. Epiginio 23 (22-23) de largura, 15 (13-16) de comprimento, com 8 estrias longitudinais em uma fileira; seta genital com 12 (11-15) de comprimento. Opistossoma -anéis praticamente subiguais dorsoventralmente; anéis completamente microtuberculados, com exceção de duas regiões lisas que extendem-se por todo o comprimento do opistossoma. Microtubérculos em forma de contas, conspícuos. Anéis terminais 5-6 dorsalmente lisos e ventralmente com microtubérclos finos e alongados. Seta lateral com 25 (24-27) de comprimento, sobre o anel 2-3 (2-4); seta ventral 1 sobre o anel 10-11 (10-15), separadas em 40 (3539) por 10 (10-14) microtubérculos, de 40 (35-30) de comprimento; seta ventral 2 sobre o anel 23 (23-29), separadas em 19 (17-19) por 5 (4-6) microtubérculos, de 14 (13-16) de comprimento; seta ventral 3 sobre o anel 39 (38-47), separadas em 22 (20-25) por 5 (5-7) microtubérculos, de 26 (25-29) de comprimento. Número total de anéis dorsais 48 (47-56), total de anéis ventrais 44 (32-53). Seta caudal 53 (52-55) de comprimento; seta acessória 6 (6-7) de comprimento. 
Macho . Medidas em micrômetros; alótipo com a variação de 3 parátipos.

Menor que a fêmea, 161 (143-187) de comprimento; 50 (52-53) de largura. Gnatossoma 24 (26-28) de comprimento, seta basal não vista, seta anti-apical com 4 (45) de comprimento; quelíceras (20-24) de comprimento. Escudo prodorsal 26 (26-30) de comprimento, 46 (45-48) de largura, tubérculos setais separados em 18 (18-21), de 18 (17-18) de comprimento. Pernas com todas as setas normais. Pernas I 26 (27-30); fêmur 7 (6-8), seta do fềmur 7 (6-7); genu 4 (4-4), seta do genu 19 (17-18); tíbia 6 (5-6), seta da tíbia 4 (4-4); tarso 5 (6-7), seta lateral 18 (19-19), seta dorsal 14 (12-14), seta mesal 4 (4-4), solenídio 8 (7-8), empódio 6 (6-6) de comprimento com 6 raios. Pernas II 25 (25-26); fềmur 7 (6-7), seta do fềmur 6 (6-7); genu 4 (4-4), seta do genu 6 (7-9); tíbia 4 (4-5); tarso 5 (5-5), seta lateral 20 (18-21), seta dorsal 4 (4-5), seta mesal 3 (3-4), solenídio 8 (8-8), empódio 6 (6-6) de comprimnto com 6 raios. Coxa, seta coxal 1, 5 (58) e separadas em 12 (12-13); seta coxal 2, 12 (11-14) e separadas em 9 (9-10); seta coxal 3, 28 (23-29) e separadas em 22 (19-22). Coxas com poucos grânulos. Linha esternal com (4-5) de comprimento. Região coxiesternal com 6 (5-6) anéis, microtuberculados. Genitália 18 (18-19) de largura, 14 (13-15) de comprimento, granulada; papilas pontiagudas, como mostrado na Figura 21; estruturas genitais internas complexas, não completamente entendidas (Figura 22); seta genital com 11 (10-11) de comprimento. Opistossoma como na fêmea; seta lateral com 20 (20-22) de comprimento, sobre o anel 1 (1-2); seta ventral 1 sobre o anel 8-9 (8-10), separadas em 33 (31-32) por 11 (9-11) microtubérculos, de 25 (31-33) de comprimento; seta ventral 2 sobre o anel 18 (18-20), separadas em 17 (16-17) por 7 (4-5) microtubérculos, de 11 (12-13) de comprimento; seta ventral 3 sobre o anel 33 (32-35), separadas em 21 (13-19) por 9 (5-6) microtubérculos, de 26 (23-26) de comprimento. Número total de anéis dorsais 42 (41-42), total de anéis ventrais 38 (37-40). Seta caudal 41 (42-46) de comprimento; seta acessória 6 (6-7) de comprimento.

Material Tipo. Holótipo fêmea, 30 parátipos fềmeas; alótipo macho, 3 parátipos machos, em 12 preparações microscópicas, na coleção do Departamento de Zoologia, Universidade de São Paulo - ESALQ, Piracicaba, São Paulo, Brasil. 
Localidade Tipo. Planaltina, Distrito Federal, Brasil. Janeiro de 1995, coletado por DNMF.

Planta Hospedeira . Coletados de gemas de Arachis pintoi (Krap. \& Greg.) (Fabaceae).

Relação com a Planta Hospedeira. Os ácaros são "leaf vagrants", causando leve bronzeamento.

Etimologia. pintoi da designação específica da planta hospedeira.

Portanto, não se recomenda a utilização de estolhos para a propagação de A. pintoi, pois estes podem servir como fonte de infestação dos ácaros detectados. Caso seja necessária a propagação destas plantas por meio de estolhos, deve-se proceder uma cuidadosa inspeção do material antes do plantio. T. ogmophallos, pertencente á família Tetranychidae, onde encontram-se os ácaros-praga de maior importância agrícola, pode causar problemas não só à cultura de $A$. pintoi, como também a pelo menos uma outra cultura de importância econômica - o amendoim. Os eriofí́deos $A$. pintoi, por suas reduzidas dimensões e por encontrarem-se em locais protegidos nas plantas, podem facilmente passar desapercebidos em uma inspeção superficial do material. 

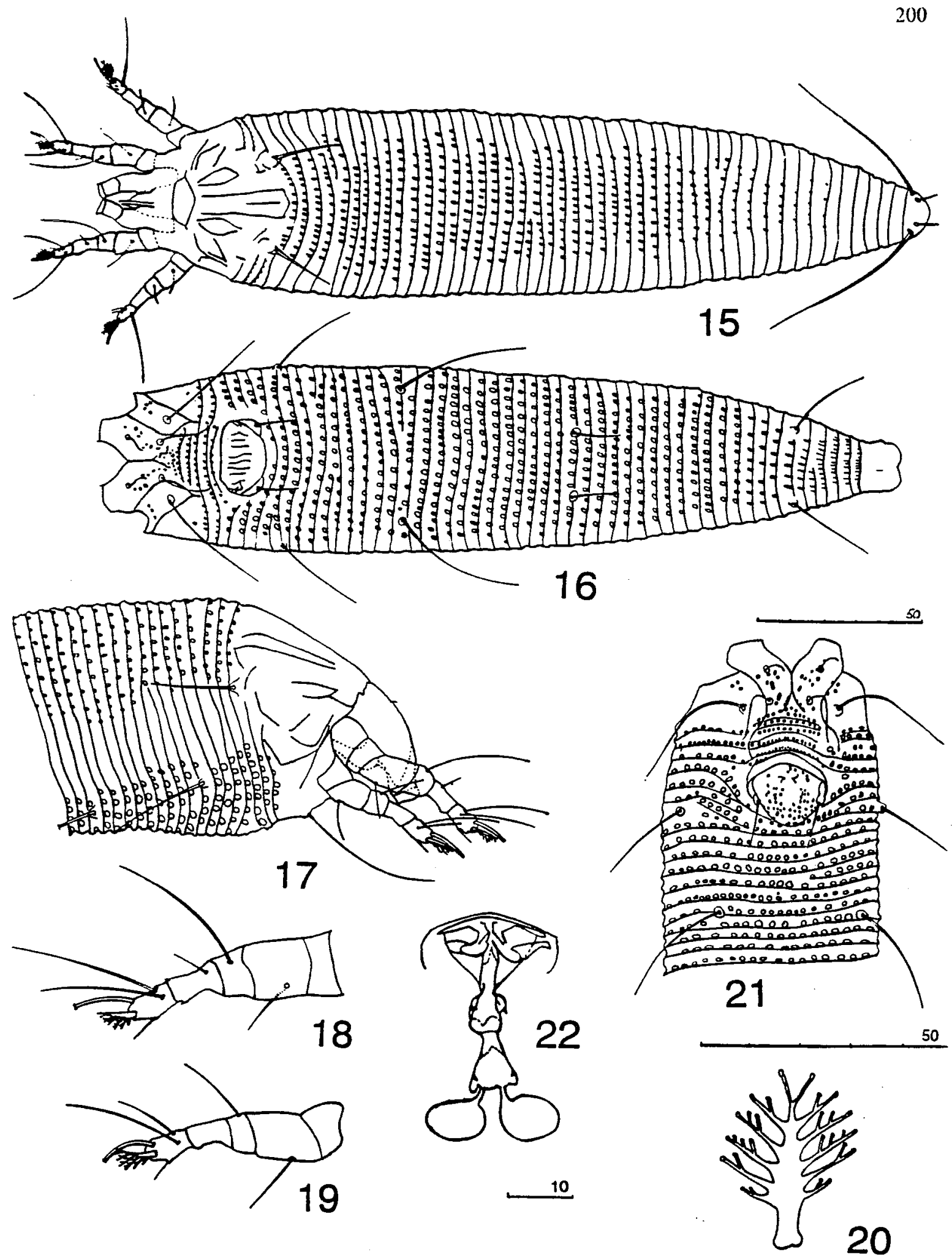

Figuras 4.15-22-Aceria pintoi Ferreira \& Flechtmann; 15-20 fêmea; 21-22 macho. 15- vista dorsal; 16- vista ventral; 17- vista lateral; 18- perna I; 19- perna II; 20- empódio (ampliado); 21- aspecto ventral; 22- estruturas genitais internas. 


\subsection{CONCLUSÕES}

- Estolhos de Arachis pintoi (Krap. \& Greg) podem servir como fonte de infestação de ácaros fitófagos pertencentes às espécies $A$. pintoi e $T$. ogmophallos.

- Além de culturas de A. pintoi, T. ogmophallos pode infestar A. prostrata $e$ A. hypogeae, o amendoim. 


\section{ANEXO A. ÁCAROS INTERCEPTADOS EM MATERIAL VEGETAL IMPORTADO.}

Tabela 1. Espécies de Rhizoglyphus interceptadas na Nova Zelândia associadas a material vegetal proveniente de diferentes países. (MANSON, 1972).

\begin{tabular}{lll}
\hline \multicolumn{1}{c}{ Espécie } & \multicolumn{1}{c}{ Produto } & \multicolumn{1}{c}{ País de Origem } \\
\hline $\begin{array}{c}\text { Rhizoglyphus caladii } \\
\text { Manson }\end{array}$ & tubérculo de Caladium & Nova Guiné \\
\hline $\begin{array}{c}\text { Rhizoglyphus echinopus } \\
\text { (Fumouze \& Robin) }\end{array}$ & bulbos e material vegetal & Holanda, Reino Unido \\
\hline $\begin{array}{c}\text { Rhizoglyphus howensis } \\
\text { Manson }\end{array}$ & semente de palmeira & Ilha de Lord Howe (Austrália) \\
\hline $\begin{array}{l}\text { Rhizoglyphus minutus } \\
\text { Manson }\end{array}$ & taro & Niue (llha Pacífico) \\
\hline $\begin{array}{l}\text { Rhizoglyphus setosus } \\
\text { Manson }\end{array}$ & diversos & Pacifico Sul \\
\hline $\begin{array}{l}\text { Rhizoglyphus singularis } \\
\text { Manson }\end{array}$ & inhame & India \\
\hline $\begin{array}{l}\text { Rhizoglyphus tacitri } \\
\text { Manson }\end{array}$ & raiz de Citrus & Tahiti \\
\hline
\end{tabular}

Fonte Manson (1972).

${ }^{1}$ espécie cosmopolita, já assinalda na Nova Zelândia

2 espécie nova 
Tabela 2. Espécies de ácaros detectadas em produtos alimentícios de origem vegetal na Califórnia - EUAN, provenientes de países orientais, no periodo de setembro de 1980 a agosto de 1982 .

\begin{tabular}{|c|c|c|}
\hline Espécie Interceptada & Produto & País de Origem \\
\hline Acarus siro L. complexo & tofu & China e Japão \\
\hline $\begin{array}{l}\text { Aleuroglyphus ovatus } \\
\text { (Troupeau) }\end{array}$ & tofu & China, Japão e Tailândia \\
\hline $\begin{array}{l}\text { Caloglyphus hughesi } \\
\text { Samsinak }\end{array}$ & tamarindo & Tailândia \\
\hline $\begin{array}{l}\text { Caloglyphus oudemansi } \\
\text { (Zachvatkin) }\end{array}$ & $\begin{array}{l}\text { tofu } \\
\text { tamarindo }\end{array}$ & $\begin{array}{l}\text { Tailândia } \\
\text { Filipinas }\end{array}$ \\
\hline Caloglyphus sp. & $\begin{array}{l}\text { tofu } \\
\text { açúcar cru }\end{array}$ & $\begin{array}{l}\text { Japão } \\
\text { México }\end{array}$ \\
\hline Carpoglyphus lactis L. & $\begin{array}{l}\text { tofu } \\
\text { côco fermentado } \\
\text { tâmara } \\
\text { ameixa seca } \\
\text { açúcar cru } \\
\text { tamarindo } \\
\end{array}$ & $\begin{array}{l}\text { China, Japão, Coréia, Taiwan, } \\
\text { Tailândia } \\
\text { Filipinas } \\
\text { Japão } \\
\text { China } \\
\text { China, México } \\
\text { Indonésia e Tailândia } \\
\end{array}$ \\
\hline $\begin{array}{l}\text { Chortogbphus arcuatus } \\
\text { (Troupeau) }\end{array}$ & $\begin{array}{l}\text { tofu } \\
\text { ervas } \\
\end{array}$ & $\begin{array}{l}\text { Tailândia } \\
\text { China }\end{array}$ \\
\hline $\begin{array}{l}\text { Dermatophagoides farinae } \\
\text { Hughes }\end{array}$ & molho de feijão & Tailândia \\
\hline $\begin{array}{l}\text { Dermatophagoides pteronyssus } \\
\text { (Trouessart) }\end{array}$ & $\begin{array}{l}\text { tamarindo } \\
\text { tofu }\end{array}$ & $\begin{array}{l}\text { Tailândia } \\
\text { Filipinas }\end{array}$ \\
\hline $\begin{array}{l}\text { Euroglyphus maynei } \\
\text { (Cooreman) }\end{array}$ & tofu & China \\
\hline $\begin{array}{l}\text { Lepidoglyphus fustifer } \\
\text { (Oudemans) }\end{array}$ & tofi, ervas, algas & China \\
\hline $\begin{array}{l}\text { Suidasia pontifica } \\
\text { Oudemans }\end{array}$ & $\begin{array}{l}\text { tofu } \\
\text { pimenta em pó } \\
\text { pimenta em conserva } \\
\text { picles }\end{array}$ & $\begin{array}{l}\text { China, Japão, Taiwan } \\
\text { Tailândia } \\
\text { Tailândia } \\
\text { Índia }\end{array}$ \\
\hline $\begin{array}{l}\text { Thyreophagus entomophagus } \\
\text { (Laboulbène) }\end{array}$ & gengibre & Japão \\
\hline $\begin{array}{l}\text { Thyreophagus gallegoi } \\
\text { Portus \& Gomez }\end{array}$ & $\begin{array}{l}\text { tofu } \\
\text { "hoisin sauce" }\end{array}$ & $\begin{array}{l}\text { Japão e Filipinas } \\
\text { Japão }\end{array}$ \\
\hline $\begin{array}{l}\text { Tyrophagus putrescentiae } \\
\text { (Schrank) }\end{array}$ & $\begin{array}{l}\text { broto-de-bambu,ameixa } \\
\text { tofu } \\
\text { jujuba (tâmara vermelha) } \\
\text { algas,açúcar crú, cevada } \\
\text { vegetais em conserva, vinagre }\end{array}$ & $\begin{array}{l}\text { Taiwan } \\
\text { Japão, China, Taiwan e Tailândia } \\
\text { China } \\
\text { Japão }\end{array}$ \\
\hline
\end{tabular}

Fonte Olsen (1983). 
Tabela 3 Espécies das familia Tetranychidae e Tenuipalpidae detectadas em material vegetal interceptado em portos e aeroportos da Nova Zelândia no período de 1958 a 1966.

\begin{tabular}{|c|c|c|}
\hline Espécie Interceptada & Hospedeiro & País de Origem \\
\hline $\begin{array}{l}\text { Brevipalpus californicus } \\
\text { (Banks) }\end{array}$ & $\begin{array}{l}\text { Cattleya sp. } \\
\text { Codiaeum sp. e Gardenia sp. e Solanum melongena } \\
\text { Cymbidium longifolium } \\
\text { Murraya koenigii e Plumeria sp. }\end{array}$ & $\begin{array}{l}\text { Austrália } \\
\text { Samoa } \\
\text { Índia } \\
\text { Fiji } \\
\end{array}$ \\
\hline $\begin{array}{l}\text { Brevipalpus obovatus } \\
\text { Donnadieu }\end{array}$ & $\begin{array}{l}\text { Gerbera sp. } \\
\text { Hibiscus sp. e Plumeria sp. } \\
\text { Piper betle }\end{array}$ & $\begin{array}{l}\text { Cook Is. } \\
\text { Norfolk Is. } \\
\text { Fiji } \\
\end{array}$ \\
\hline $\begin{array}{l}\text { Brevipalpus phoenicis } \\
\text { (Geijskes) }\end{array}$ & $\begin{array}{l}\text { Acalypha sp., Citrus sinensis } \\
\text { Citrus aurantifoia e C. limonia } \\
\text { Citrus limonia e Solanum melongena } \\
\text { Citrus paradise } \\
\text { Citrus paradise e Cocos nucifera } \\
\text { Citrus sinensis, Citrus sp., Hibiscus sp. } \\
\text { Citrus sinensis } \\
\text { Citrus sinensis, Citrus sp. } \\
\text { Citrus sinensis } \\
\text { Coleus sp., Gardenia } \text { sp., Hibiscus sp., } \\
\text { Murraya koenigii, Piper betle, Plumeria sp. }\end{array}$ & $\begin{array}{l}\text { Norfolk Is. } \\
\text { Tonga } \\
\text { Samoa } \\
\text { Society Is. } \\
\text { Tahiti } \\
\text { Cook Is. } \\
\text { New Caledonia } \\
\text { Pitcaim Is. } \\
\text { África do Sul } \\
\text { Fiji }\end{array}$ \\
\hline $\begin{array}{l}\text { Eotetranychus queenslandicus } \\
\text { Manson }^{2}\end{array}$ & Codiaeum sp. & Austrália \\
\hline $\begin{array}{l}\text { Schizotetranychus baltazarae } \\
\text { Rimando }\end{array}$ & Murraya koenigii & India \\
\hline Tenuipalpus pacificus Baker & $\begin{array}{l}\text { Cattleya sp. e Platycerium sp. } \\
\text { Orchidaceae }\end{array}$ & $\begin{array}{l}\text { Austrália } \\
\text { Singapura }\end{array}$ \\
\hline Tetranychus Iudeni Zacher & rosa & Austrália \\
\hline $\begin{array}{l}\text { Tetranychus neocaledonicus } \\
\text { Andre }\end{array}$ & Codiaeum sp. & Austrália \\
\hline Tetranychus sp. & $\begin{array}{l}\text { Citrus sinensis } \\
\text { Clematis sp. } \\
\text { Cocos nucifera } \\
\text { Diospyros sp. } \\
\text { Hibiscus sp. } \\
\text { Philodendron } \mathrm{sp} .\end{array}$ & $\begin{array}{l}\text { Austrália } \\
\text { Reino Unido } \\
\text { Cook Is. } \\
\text { Samoa } \\
\text { Fiji } \\
\text { EUAN } \\
\end{array}$ \\
\hline Tetranychus urticae (Koch) & $\begin{array}{l}\text { Fragaria vesca } \\
\text { Malus sylvestris (frutos), Rosa sp., Orchidaceae }\end{array}$ & $\begin{array}{l}\text { Inglaterra } \\
\text { Austrália }\end{array}$ \\
\hline
\end{tabular}

\section{Fonte Manson (1967)}

'espécie não assinalada na Nova Zelândia

${ }^{2}$ espécie nova 
Tabela 4. Tetraniquídeos detectados em abóboras importadas no Japão.

\begin{tabular}{ll}
\hline \multicolumn{1}{c}{ Espécie detectada } & País de origem \\
\hline Panonychus citri (McGregor) & EUAN \\
\hline Tetranychus cinnabarinus (Boisduval) & EUAN \\
\hline Tetranychus gigas Pritchard \& Baker * & EUAN \\
\hline Tetranychus hydrangeae Pritchard \& Baker * & EUAN, México \\
\hline Tetranychus lambi Pritchard \& Baker * & Nova Zelândia \\
\hline Tetranychus pacificus McGregor * & EUAN \\
\hline Tetranychus sp. & EUAN, Mexico, Nova Zelândia, Colômbia \\
\hline Tetranychus turkestani (Ugarov \& Nikolskii) ${ }^{*}$ & EUAN \\
\hline Tetranychus urticae Koch & EUAN, Nova Zelândia \\
\hline
\end{tabular}

Fonte Masaki et al. (1991)

* espécies não assinaladas no Japão 
Tabela 5. Principais espécies da subordem Astigmata interceptadas pelo "Yokohama Plant Protection Station", Japão.

\begin{tabular}{|c|c|c|}
\hline Espécie interceptada & Produto & País de origem \\
\hline \multicolumn{3}{|l|}{ Acaridae } \\
\hline $\begin{array}{l}\text { Caloglyphus berlesei } \\
\text { (Michael) }\end{array}$ & alho & China e Taiwan \\
\hline $\begin{array}{l}\text { Caloglyphus mycophagus } \\
\text { (Mégnin) }\end{array}$ & $\begin{array}{l}\text { gengibre } \\
\text { cebola } \\
\text { Selloum }\end{array}$ & $\begin{array}{l}\text { Tailândia } \\
\text { Taiwan } \\
\text { Indonésia }\end{array}$ \\
\hline Caloglyphus sp. & "golden lycoris" e tuberosa & Taiwan \\
\hline $\begin{array}{l}\text { * Rhizoglyphus echinopus } \\
\text { ( Fumouze \& Robin) }\end{array}$ & $\begin{array}{l}\text { cila, tulipa e Narcissus } \\
\text { chalota } \\
\text { Wakegi }\end{array}$ & $\begin{array}{l}\text { Holanda } \\
\text { França } \\
\text { Taiwan }\end{array}$ \\
\hline $\begin{array}{l}\text { Rhizoglyphus robini } \\
\text { Claparède }\end{array}$ & $\begin{array}{l}\text { cebola } \\
\text { Wakegi } \\
\text { alho } \\
\text { gengibre } \\
\text { chalota } \\
\text { Colocasia } \\
\text { Curcuma siamensis } \\
\text { Ornithogalum } \\
\text { orquideas } \\
\text { tulipa e Hyacinthus }\end{array}$ & $\begin{array}{lll}\text { EUAN, Taiwan, Corea, Nova } \\
\text { Zelândia } \\
\text { Coréia } \\
\text { EUAN, Taiwan } & & \\
\text { Taiwan e Tailândia } & & \\
\text { Bélgica, França } & \\
\text { Taiwan } & \\
\text { Tailândia } & \\
\text { Israel } & \\
\text { Indonésia } & \\
\text { Holanda } & \\
\end{array}$ \\
\hline Rhizoglyphus sp. & $\begin{array}{l}\text { Erythronium } \\
\text { Ornithogalum } \\
\text { Taro } \\
\end{array}$ & $\begin{array}{l}\text { Holanda } \\
\text { Israel } \\
\text { Taiwan } \\
\end{array}$ \\
\hline $\begin{array}{l}\text { * Schwiebia zingiberi } \\
\text { Manson }\end{array}$ & Zingiber officinale & Indonésia \\
\hline $\begin{array}{l}\text { Suidasia medanensis } \\
\text { Oudemans }\end{array}$ & alho & China \\
\hline $\begin{array}{l}\text { * Tyrophagus longior } \\
\text { (Gervais) }\end{array}$ & cebola & EUAN \\
\hline $\begin{array}{l}\text { * Tyrophagus oudemansi } \\
\text { Robertson }\end{array}$ & $\begin{array}{l}\text { cebola } \\
\text { beterraba }\end{array}$ & $\begin{array}{l}\text { Austrália } \\
\text { Holanda } \\
\end{array}$ \\
\hline $\begin{array}{l}\text { Tyrophagus putrescentiae } \\
\text { (Schrank) }\end{array}$ & $\begin{array}{l}\text { cebola } \\
\text { Wakegi } \\
\text { laranja, abóbora } \\
\text { kiwi } \\
\text { rosa } \\
\text { crisântemo } \\
\text { Cymbidium } \\
\text { Dendrobium }\end{array}$ & $\begin{array}{l}\text { Coréia, Tailândia, Nova Zelândia } \\
\text { Coréia } \\
\text { EUAN } \\
\text { Nova Zelândia } \\
\text { Canadá } \\
\text { Taiwan } \\
\text { Nova Zelândia } \\
\text { Singapura }\end{array}$ \\
\hline
\end{tabular}




\begin{tabular}{lll}
\hline Tyrophagus sp. & Tillandsia & Costa Rica \\
& Ornithogalum & Israel \\
& crisântemo & Taiwan \\
& cebola & Austrália, Nova Zelândia, Taiwan \\
& aspargo & Austrália, Nova Zelândia \\
& Dendrobium e Anthurium & Havaí \\
& gerbera, Hyacinthus & Holanda \\
& côco, banana & Filipinas \\
\hline Glycyphagidae & & \\
\hline Glycyphagus destructor & Wakegi & Taiwan \\
(Schrank) & & \\
\hline Glycyphagus sp. & cebola & EUAN \\
& Wakegi & Taiwan \\
\hline
\end{tabular}

Fonte Masaki (1991), Kaneda (1993)

* espécies não assinaladas no Japão

Tabela 6. Principais espécies da subordem Prostigmata interceptadas pelo "Yokohama Plant Protection Station", Japão (MASAKI, 1991; KANEDA, 1993).

\begin{tabular}{|c|c|c|}
\hline Espécie interceptada & Produto & País de origem \\
\hline \multicolumn{3}{|l|}{ Eriophyidae } \\
\hline Eriophyes tulipae (Keifer) & chalota & França, EUAN \\
\hline \multicolumn{3}{|l|}{ Tarsonemidae } \\
\hline Daidalotarsonemus sp. & Dendrobium & Singapura \\
\hline Tarsonemus bilobatus Suski & Curcubita sp. & EUAN \\
\hline Tarsonemus sp. & $\begin{array}{l}\text { "silver tree" } \\
\text { abóbora } \\
\text { Dracaena }\end{array}$ & $\begin{array}{l}\text { Nova Zelândia } \\
\text { EUAN } \\
\text { Taiwan } \\
\end{array}$ \\
\hline \multicolumn{3}{|l|}{ Tenuipalpidae } \\
\hline $\begin{array}{l}\text { Brevipalpus californicus } \\
\text { (Banks) }\end{array}$ & Dendrobium sp. & Taiwan \\
\hline $\begin{array}{l}\text { Brevipalpus phoenicis } \\
\text { (Geijskes) }\end{array}$ & $\begin{array}{l}\text { Lucospermum sp. } \\
\text { Curcubita sp. }\end{array}$ & $\begin{array}{l}\text { Havaí } \\
\text { Tonga }\end{array}$ \\
\hline Brevipalpus sp. & $\begin{array}{l}\text { orquídea } \\
\text { abóbora } \\
\text { "Belmore sentry palm" }\end{array}$ & $\begin{array}{l}\text { Peru } \\
\text { México } \\
\text { Taiwan } \\
\end{array}$ \\
\hline $\begin{array}{l}\text { Dolichotetranychus floridanus } \\
\text { (Banks) }\end{array}$ & abacaxi & Filipinas, Taiwan, Havaí \\
\hline * Dolichotetranychus sp. & Tillandsia & Guatemala \\
\hline * Tenuipalpus pacificus Baker & $\begin{array}{l}\text { Dendrobium } \\
\text { Nephlolepis }\end{array}$ & $\begin{array}{l}\text { Tailândia, Singapura } \\
\text { Tailândia }\end{array}$ \\
\hline \multicolumn{3}{|l|}{ Tetranychidae } \\
\hline Bryobia sp. & Ornithogalum, lírio & Holanda \\
\hline
\end{tabular}




\begin{tabular}{|c|c|c|}
\hline . & $\begin{array}{l}\text { "wax flower" } \\
\text { Ananas } \\
\text { Tillandsia } \\
\text { repolho chinês } \\
\text { cone de pinheiro }\end{array}$ & $\begin{array}{l}\text { Israel } \\
\text { Tailândia } \\
\text { EUAN } \\
\text { Coréia } \\
\text { Nova Zelândia }\end{array}$ \\
\hline Eurytetranychus sp. & cróton & Tailândia \\
\hline Oligonychus biharensis (Hirst) & Ficus retusa & Taiwan \\
\hline Oligonychus sp. & crisântemo & Taiwan \\
\hline $\begin{array}{l}\text { Panonychus citri } \\
\text { (McGregor) }\end{array}$ & $\begin{array}{l}\text { Citrus sp. } \\
\text { abóbora }\end{array}$ & $\begin{array}{l}\text { China } \\
\text { EUAN }\end{array}$ \\
\hline Panonychus ulmi (Koch) & árvores de ameixa & Alemanha \\
\hline $\begin{array}{l}\text { Tetranychus cinnabarinus } \\
\text { (Boisduval) }\end{array}$ & $\begin{array}{l}\text { Cymbidium } \\
\text { cravo } \\
\text { crisântemo } \\
\text { abóbora } \\
\text { Callistephus }\end{array}$ & $\begin{array}{l}\text { Austrália, Nova Zelândia } \\
\text { Holanda, EUAN, Sri Lanka } \\
\text { Taiwan } \\
\text { EUAN } \\
\text { França } \\
\end{array}$ \\
\hline * Tetranychus desertorum Banks & Curcubita sp. & EUAN \\
\hline $\begin{array}{l}\text { * Tetranychus gigas } \\
\text { Pritchard \& Baker }\end{array}$ & abóbora & EUAN \\
\hline $\begin{array}{l}{ }^{*} \text { Tetranychus hydrangeae } \\
\text { Pritchard \& Baker }\end{array}$ & abóbora & EUAN, México \\
\hline $\begin{array}{l}\text { Tetranychus kanzawai } \\
\text { Kishida }\end{array}$ & $\begin{array}{l}\text { pêra } \\
\text { Gladiolus e tartago } \\
\text { rosa }\end{array}$ & $\begin{array}{l}\text { Coréia } \\
\text { Taiwan } \\
\text { Indonésia } \\
\end{array}$ \\
\hline $\begin{array}{l}{ }^{*} \text { Tetranychus lambi } \\
\text { Pritchard \& Baker }\end{array}$ & abóbora & Nova Zelândia \\
\hline $\begin{array}{l}\text { * Tetranychus neocaledonicus } \\
\text { Andre }\end{array}$ & Curcubita sp. & Tonga \\
\hline * Tetranychus pacificus McGregor & abóbora & EUAN \\
\hline Tetranychus truncatus Ehara & $\begin{array}{l}\text { crisântemo } \\
\text { rosa }\end{array}$ & $\begin{array}{l}\text { Taiwan } \\
\text { Indonésia }\end{array}$ \\
\hline $\begin{array}{l}\text { * Tetranychus turkestani } \\
\text { (Ugarov \& Nikolski) }\end{array}$ & abóbora & EUAN \\
\hline $\begin{array}{l}\text { Tetranychus urticae } \\
\text { Koch }\end{array}$ & $\begin{array}{l}\text { abóbora } \\
\text { crisântemo } \\
\text { cravo } \\
\text { perilla } \\
\text { rosa } \\
\text { Gypsophilla } \\
\text { áster } \\
\text { wideleaf sea lavender } \\
\text { Gladiolus } \\
\text { Montbretia sp. } \\
\text { Hedera sp. } \\
\text { couve-de- Bruxelas } \\
\end{array}$ & $\begin{array}{l}\text { EUAN, Nova Zelândia } \\
\text { Taiwan, Holanda, Singapura } \\
\text { EUAN, Taiwan, Sri Lanka } \\
\text { Coréia } \\
\text { Canadá, Malásia, Singapura } \\
\text { Malásia } \\
\text { Malásia, Singapura } \\
\text { Nova Zelânđia } \\
\text { Taiwan } \\
\text { EUAN } \\
\text { Reino Unido } \\
\text { Austrália } \\
\end{array}$ \\
\hline Tetranychus viennensis Zacher & maçã & China \\
\hline
\end{tabular}

Fonte Masaki (1991), Kaneda (1993)

* espécies não assinaladas no Japão 
Tabela 7. Ácaros interceptados na Holanda -"Plant Protection Service ", em plantas importadas, nos anos de 1992 e 1994.

\begin{tabular}{|c|c|c|}
\hline Espécies interceptadas & Hospedeiros & Países de origem \\
\hline \multicolumn{3}{|l|}{ Eriophyidae } \\
\hline Aceria sp. & Zelkova bonsais & \\
\hline \multicolumn{3}{|l|}{ Penthalodidae } \\
\hline Penthalodes ovalis (Dugés) & Begonia & Alemanha \\
\hline \multicolumn{3}{|l|}{ Tetranychidae } \\
\hline $\begin{array}{l}\text { Oligonychus perditus } \\
\text { Pritchard \& Baker }\end{array}$ & Juniperus chinensis (bonsai) & Japão \\
\hline $\begin{array}{l}\text { Panonychus citri } \\
\text { (McGregor) }\end{array}$ & $\begin{array}{l}\text { Citrus } \\
\text { Ilex crenata } \\
\text { Ficus benjamina } \\
\text { Murraya } \\
\end{array}$ & $\begin{array}{l}\text { Honduras } \\
\text { Japão } \\
\text { Costa Rica } \\
\text { China } \\
\end{array}$ \\
\hline $\begin{array}{l}\text { Tetranychus amicus } \\
\text { Meyer \& Rodrigues }\end{array}$ & $\begin{array}{l}\text { Bergeranthus, Faucaria, } \\
\text { e Chasmatophyllum }\end{array}$ & África do Sul \\
\hline Tetranychus urticae Koch & $\begin{array}{l}\text { Bambus } \\
\text { Dianthus } \\
\end{array}$ & $\begin{array}{l}\text { EUAN } \\
\text { Israel } \\
\end{array}$ \\
\hline $\begin{array}{l}\text { Tetranychus nakahari } \\
\text { Baker \& Tuttle }\end{array}$ & Citrofortunella & Guatemala \\
\hline Tetranychus tumidus Banks & Phoenix & Cuba \\
\hline Tetranychus sp. & Dianthus & Israel \\
\hline
\end{tabular}

Fonte: Ackerman et al. (1994 e 1995) 


\section{ANEXO B. IMPORTAÇÕES BRASILEIRAS DE PRODUTOS VEGETAIS}

Tabela 1. Volume das importações de maçãs pelo Brasil em toneladas (Q) e número de lotes importados ( $\left.\mathrm{N}^{\circ} \mathrm{L}\right)$ de janeiro de 1992 a agosto de 1996.

\begin{tabular}{|c|c|c|c|c|c|c|c|c|c|c|c|c|}
\hline \multirow{2}{*}{$\begin{array}{c}\text { País } \\
\text { exportador }\end{array}$} & \multicolumn{2}{|c|}{1992} & \multicolumn{2}{|c|}{1993} & \multicolumn{2}{|l|}{1994} & \multicolumn{2}{|l|}{1995} & \multicolumn{2}{|l|}{1996} & \multicolumn{2}{|l|}{ Total } \\
\hline & $\mathbf{Q}$ & $\mathbf{N}^{0} \mathbf{L}$ & $\mathbf{Q}$ & $\mathbf{N}^{\circ} \mathbf{L}$ & $\mathbf{Q}$ & $\mathbf{N}^{\circ} \mathbf{L}$ & $\mathbf{Q}$ & $\mathbf{N}^{0} \mathbf{L}$ & $\mathbf{Q}$ & $\mathbf{N}^{\circ} \mathbf{L}$ & $\mathbf{Q}$ & $\mathbf{N}^{\mathbf{N}} \mathbf{L}$ \\
\hline Argentina & 390,70 & 3 & $3.245,75$ & 66 & $360.415,19$ & 94 & $20.140,93$ & 171 & $6.110,05$ & 85 & $390.302,62$ & 419 \\
\hline EUAN & 64,08 & 2 & 336.67 & 8 & $3.076,88$ & 9 & $5.677,48$ & 23 & $1.061,53$ & 7 & $10.216,64$ & 49 \\
\hline Chile & & & \begin{tabular}{|l|}
$1.736,02$ \\
\end{tabular} & 22 & 226,24 & 7 & $3.226,94$ & 12 & 342,70 & 4 & $5.531,90$ & 45 \\
\hline França & 0,02 & 1 & & & $1.173,35$ & 1 & $2.768,37$ & 8 & & & $3.941,74$ & 10 \\
\hline N. Zelândia & & & & & & & 600,59 & 1 & & & 600,59 & 1 \\
\hline Paraguai & & & & & 400,00 & 1 & & & & & 400,00 & 1 \\
\hline Holanda & 0,04 & 1 & & & 292,15 & 1 & & & & & 292,19 & 2 \\
\hline Hungria & & & 53,08 & 1 & 156,00 & 2 & 39 & 1 & & & 248,08 & 4 \\
\hline Espanha & & & & & & & 237,35 & 3 & & & 237,35 & 3 \\
\hline Canadá & 29,68 & 1 & & & & & 166,32 & 2 & & & 196,00 & 3 \\
\hline Itália & & & & & 88,72 & 2 & & & 0,01 & 1 & 88,73 & 3 \\
\hline Inglaterra & & & & & 38,81 & 1 & & & & & 38,81 & 1 \\
\hline Arábia Saudita & & & & & 21,00 & 1 & & & & & 21,00 & 1 \\
\hline Suriname & 0,005 & 1 & & & & & & & & & 0,005 & 1 \\
\hline
\end{tabular}

Fonte: Brasil (1996)

Tabela 2. Volume das importações de pêras pelo Brasil em toneladas (Q) e número de lotes importados ( $\left.\mathrm{N}^{\circ} \mathrm{L}\right)$ de janeiro de 1992 a agosto de 1996.

\begin{tabular}{|c|c|c|c|c|c|c|c|c|c|c|c|c|}
\hline \multirow{2}{*}{$\begin{array}{c}\text { País } \\
\text { exportador }\end{array}$} & \multicolumn{2}{|c|}{1992} & \multicolumn{2}{|c|}{1993} & \multicolumn{2}{|l|}{1994} & \multicolumn{2}{|c|}{1995} & \multicolumn{2}{|l|}{1996} & \multicolumn{2}{|c|}{ Total } \\
\hline & $\mathbf{Q}$ & $\mathbf{N}^{\circ} \mathbf{L}$ & $\mathbf{Q}$ & $\sigma^{\infty} \mathbf{L}$ & & $N^{\circ} \mathbf{L}$ & $\mathbf{Q}$ & $\mathbf{N}^{\circ} \mathbf{L}$ & $\mathbf{Q}$ & $\mathbf{N}^{\circ} \mathbf{L}$ & $\mathbf{Q}$ & $\mathbf{N}^{\circ} \mathbf{L}$ \\
\hline Argentina & 390,72 & 1 & 1197,15 & 34 & $6.430,36$ & 80 & $21.129,98$ & 165 & $13.296,65$ & 102 & $42.444,86$ & $\overline{382}$ \\
\hline EUAN & 156,28 & 8 & 583,06 & 14 & $2.213,74$ & 15 & $7.276,92$ & 29 & 356,51 & 14 & $10.586,51$ & 80 \\
\hline Portugal & & & 723,65 & 10 & 11,00 & 1 & $1.246,44$ & 13 & 2,98 & 3 & $1.984,07$ & 27 \\
\hline Franca & & & & & & & $1.250,35$ & 9 & & & $1.250,35$ & $\overline{9}$ \\
\hline Chile & $\overline{291,00}$ & 9 & 702,92 & 7 & 29,85 & 10 & 156,18 & 5 & 27,34 & 3 & $1.207,29$ & $\overline{34}$ \\
\hline Espanha & & & & & 162,03 & 3 & 708,72 & 11 & & & 870,75 & 14 \\
\hline China & & & & & & & 450,88 & 1 & & & 450,88 & 1 \\
\hline Uruguai & 47,35 & 2 & 15,78 & 1 & 2,5 & 1 & & & & & 65,63 & 4 \\
\hline Canadá & & & 38,14 & 1 & & & & & & & 38,14 & 1 \\
\hline Nova Zelândia & & & & & & & 2,88 & 1 & & & 2,88 & - \\
\hline
\end{tabular}

Fonte: Brasil (1996) 
Tabela 3. Volume das importações de uvas pelo Brasil em toneladas (Q) e número de lotes importados $\left(\mathrm{N}^{\circ} \mathrm{L}\right)$ de janeiro de 1992 a agosto de 1996.

\begin{tabular}{|c|c|c|c|c|c|c|c|c|c|c|c|c|}
\hline \multirow{2}{*}{$\begin{array}{c}\text { País } \\
\text { exportador }\end{array}$} & \multicolumn{2}{|l|}{1992} & \multicolumn{2}{|c|}{1993} & \multicolumn{2}{|c|}{1994} & \multicolumn{2}{|c|}{1995} & \multicolumn{2}{|c|}{1996} & \multicolumn{2}{|l|}{ Total } \\
\hline & Q $\mathbf{N}^{\mathbf{0}}$ & & & $\mathbf{N}^{0} \mathbf{L}$ & & $\mathbf{N}^{0} \mathbf{L}$ & $\mathbf{Q}$ & $\mathbf{N}^{\circ} \mathbf{L}$ & $\mathbf{Q}$ & $\mathbf{N}^{\circ} \mathbf{L}$ & $\mathbf{Q}$ & $\mathbf{N}^{0} \mathbf{L}$ \\
\hline EUAN & $13.978,22$ & 6 & 240,61 & 19 & 47,24 & 4 & $1.748,11$ & 35 & 94,06 & 60 & $16.108,24$ & 124 \\
\hline Chile & 131,1 & 4 & $3.842,30$ & 16 & 476,21 & 20 & $1.692,69$ & $\overline{43}$ & 297,86 & 14 & $6.440,16$ & 97 \\
\hline Argentina & 55,00 & 1 & & & 163,71 & 4 & 109,92 & 7 & 305,71 & 11 & 634,34 & 23 \\
\hline Holanda & & & & & & & 15,13 & 3 & & & 15,13 & 3 \\
\hline China & & & & & 11,7 & 1 & & & & & 11,7 & 1 \\
\hline Uruguai & 0,01 & 1 & & & & & & & & & 0,01 & 1 \\
\hline
\end{tabular}

Fonte: Brasil (1996)

Tabela 4. Volume das importações de mudas de videiras pelo Brasil em unidades (Q) e número de lotes importados ( $\left.{ }^{\circ} \mathrm{L}\right)$ de janeiro de 1992 a agosto de 1996.

\begin{tabular}{|c|c|c|c|c|c|c|c|c|c|c|c|c|}
\hline \multirow{2}{*}{$\begin{array}{c}\text { Pais } \\
\text { exportador }\end{array}$} & \multicolumn{2}{|c|}{1992} & \multicolumn{2}{|c|}{1993} & \multicolumn{2}{|c|}{1994} & \multicolumn{2}{|c|}{1995} & \multicolumn{2}{|c|}{1996} & \multicolumn{2}{|c|}{ Total } \\
\hline & $\mathbf{Q}$ & $\mathbf{N}^{0} \mathbf{L}$ & $\mathbf{Q}$ & $N^{0} L$ & $\mathbf{Q}$ & $N^{0} L$ & $\mathbf{Q}$ & $\mathbf{N}^{\circ} \mathbf{L}$ & $\mathbf{Q}$ & $\mathbf{N}^{0} \mathbf{L}$ & $\mathbf{Q} \mathbf{N}$ & \\
\hline Africa do Sul & & & 70.100 & 1 & & & & & & & 70.100 & 1 \\
\hline Itália & & & & & & & 18.550 & 3 & & & 18.550 & 3 \\
\hline Franca & & & & & & & 16.600 & 2 & & & 16.600 & 2 \\
\hline Alemanha & & & & & 3.000 & 1 & & & 48 & 1 & 3.048 & 2 \\
\hline EUAN & & & & & 2.000 & 1 & & & 400 & $\bar{l}$ & 2.400 & $\overline{2}$ \\
\hline
\end{tabular}

Fonte: Brasil (1996) 
Tabela 5. Volume das importações de kiwis pelo Brasil em toneladas $(\mathrm{Q})$ e número de lotes importados ( $\left.\mathrm{N}^{\circ} \mathrm{L}\right)$ de janeiro de 1992 a agosto de 1996.

\begin{tabular}{|c|c|c|c|c|c|c|c|c|c|c|c|c|}
\hline \multirow{2}{*}{$\begin{array}{c}\text { País } \\
\text { exportador }\end{array}$} & \multicolumn{2}{|c|}{1992} & \multicolumn{2}{|c|}{1993} & \multicolumn{2}{|c|}{1994} & \multicolumn{2}{|c|}{1995} & \multicolumn{2}{|c|}{1996} & \multicolumn{2}{|l|}{ Total } \\
\hline & & $\mathbf{N}^{0} \mathbf{L}$ & $\mathbf{Q}$ & $\mathbf{N}^{0} \mathbf{L}$ & $\mathbf{Q}$ & $\mathbf{N}^{0} \mathbf{L}$ & & $\mathbf{N}^{0} \mathbf{L}$ & $\mathbf{Q}$ & $\mathbf{N}^{0} \mathbf{L}$ & $\mathbf{Q}$ & $\mathbf{N}^{0} \mathbf{L}$ \\
\hline Itália & & & 424,45 & 8 & 611,93 & 9 & $2.915,08$ & 17 & 300,73 & 3 & $4.252,19$ & 37 \\
\hline Chile & & & 804,23 & 27 & 260,14 & 22 & $1.562,24$ & 27 & 62,00 & 4 & $2.688,61$ & 80 \\
\hline Nova Zelândia & & & 170,97 & 4 & & & 910,00 & 4 & 20,00 & 1 & $1.100,97$ & 9 \\
\hline França & & & 89,30 & 1 & 129,00 & 3 & 866,30 & 9 & & & $1.084,60$ & 13 \\
\hline China & 3,20 & 1 & 165,63 & 2 & 2,70 & 1 & & & & & 171,53 & 4 \\
\hline Portugal & 7,17 & 1 & & & 18,00 & 1 & 35,80 & 2 & 39,60 & 1 & 100,57 & 5 \\
\hline Grécia & & & & & & & 78,62 & 1 & & & 78,62 & 1 \\
\hline Espanha & & & & & & & 60,00 & 3 & & & 60,00 & 3 \\
\hline Argentina & & & & & & & & & 20,00 & 1 & 20,00 & 1 \\
\hline EUAN & 9,41 & 1 & & & & & 7,92 & 1 & & & 17,33 & 2 \\
\hline
\end{tabular}

Fonte: Brasil (1996)

Tabela 6. Volume das importações de pêssegos pelo Brasil em toneladas $(\mathrm{Q})$ e número de lotes importados ( $\left.{ }^{\circ} \mathrm{L}\right)$ de janeiro de 1992 a agosto de 1996.

\begin{tabular}{|c|c|c|c|c|c|c|c|c|c|c|c|c|}
\hline \multirow{2}{*}{$\begin{array}{c}\text { País } \\
\text { exportador }\end{array}$} & \multicolumn{2}{|c|}{1992} & \multicolumn{2}{|c|}{1993} & \multicolumn{2}{|c|}{1994} & \multicolumn{2}{|c|}{1995} & \multicolumn{2}{|c|}{1996} & \multicolumn{2}{|c|}{ Total } \\
\hline & $\mathbf{Q}$ & $\mathbf{N}^{\circ} \mathbf{L}$ & $\mathbf{Q}$ & $\mathbf{N}^{0} \mathbf{L}$ & $\mathbf{Q}$ & $\mathbf{N}^{\circ} \mathbf{L}$ & Q 1 & $\mathbf{N}^{0} \mathbf{L}$ & & $\mathbf{N}^{\circ} \mathbf{L}$ & $\mathbf{Q}$ & $\mathbf{N}^{0} \mathbf{L}$ \\
\hline Chile & 39,9 & 8 & $9.729,29$ & 21 & 387,59 & 42 & 718,12 & 59 & 300,03 & 13 & $11.174,93$ & 143 \\
\hline EUAN & $7.903,48$ & 4 & 47,62 & 15 & 74,61 & 10 & 721,45 & 48 & 199,15 & 137 & $8.946,31$ & 214 \\
\hline Grécia & & & 0,02 & 1 & & & 428,58 & 3 & & & 428,6 & 4 \\
\hline Argentina & & & 3,2 & 1 & 7,52 & 5 & 45,12 & 5 & 229,98 & 13 & 285,82 & $\overline{24}$ \\
\hline Paraguai & & & & & & & 50,00 & 1 & & & 50,00 & 1 \\
\hline Portugal & 0,002 & 2 & & & 1,4 & 1 & 12,11 & 7 & 5,72 & 3 & 19,23 & 13 \\
\hline Espanha & & & & & & & 14,58 & 7 & 3,01 & 3 & 17,59 & 10 \\
\hline Uruguai & & & & & 4,7 & 1 & & & 1,89 & 3 & 6,59 & 4 \\
\hline Itália & & & & & & & 3,22 & 1 & & & 3,22 & 1 \\
\hline Holanda & & & & & & & 0,51 & 1 & & & 0,51 & 1 \\
\hline Franca & & & & & & & 0,20 & 2 & & & 0,20 & 2 \\
\hline
\end{tabular}

Fonte: Brasil (1996) 
Tabela 7. Volume das importações de cerejas pelo Brasil em toneladas $(\mathrm{Q})$ e número de lotes importados $\left(\mathrm{N}^{\circ} \mathrm{L}\right)$ de janeiro de 1992 a agosto de 1996.

\begin{tabular}{|c|c|c|c|c|c|c|c|c|c|c|c|c|}
\hline \multirow{3}{*}{$\begin{array}{l}\text { País } \\
\text { exportador } \\
\text { Chile }\end{array}$} & \multicolumn{2}{|c|}{1992} & \multicolumn{2}{|c|}{1993} & \multicolumn{2}{|c|}{1994} & \multicolumn{2}{|c|}{1995} & \multicolumn{2}{|c|}{1996} & \multicolumn{2}{|c|}{ Total } \\
\hline & & $\mathbf{N}^{\mathbf{0}} \mathbf{L}$ & $\mathbf{Q} \mathbf{N}$ & & $\mathbf{Q}$ & $\mathbf{N}^{0} \mathbf{L}$ & $\mathbf{Q}$ & $\mathbf{N}^{*} \mathbf{L}$ & $Q \mathbf{N}^{\mathbf{O}}$ & & $\mathbf{Q}$ & $\mathbf{N}^{\circ} \mathbf{L}$ \\
\hline & 146,68 & 17 & 225,29 & 14 & 208,20 & 26 & 120,62 & 12 & & & 700,79 & 69 \\
\hline EUAN & 4,09 & 1 & 10,38 & 4 & 18,59 & 6 & 123,25 & 17 & 57,99 & 56 & 214,30 & 84 \\
\hline Itália & & & & & & & 133,71 & 6 & 10,95 & 7 & 144,66 & 13 \\
\hline Argentina & & & & & 17,50 & 1 & 21,30 & 1 & & & 38,80 & 2 \\
\hline China & & & 13,08 & 1 & & & & & & & 13,08 & 1 \\
\hline Espanha & & & & & 10,80 & 1 & 1,35 & 1 & & & 12,15 & 2 \\
\hline Portugal & & & & & 1,12 & 1 & 2,25 & 3 & 2,30 & 4 & 5,67 & 8 \\
\hline Holanda & & & & & & & 1,67 & 2 & 0,25 & 1 & 1,92 & 3 \\
\hline Libano & & & & & & & & & 0,32 & 2 & 0,32 & 2 \\
\hline
\end{tabular}

Fonte: Brasil (1996)

Tabela 8. Volume das importações de ameixas pelo Brasil em toneladas (Q) e número de lotes importados ( $\left.\mathrm{N}^{\circ} \mathrm{L}\right)$ de janeiro de 1992 a agosto de 1996.

\begin{tabular}{|c|c|c|c|c|c|c|c|c|c|c|c|c|}
\hline \multirow{2}{*}{$\begin{array}{c}\text { País } \\
\text { exportador }\end{array}$} & \multicolumn{2}{|l|}{1992} & \multicolumn{2}{|c|}{1993} & \multicolumn{2}{|c|}{1994} & \multicolumn{2}{|c|}{1995} & \multicolumn{2}{|c|}{1996} & \multicolumn{2}{|c|}{ Total } \\
\hline & $\mathbf{Q}$ & & $\mathbf{Q}$ & $\mathbf{N}^{\circ} \mathbf{L}$ & $\mathbf{Q}$ & $\mathbf{N}^{0} \mathbf{L}$ & $\mathbf{Q}$ & $\mathbf{N}^{0} \mathbf{L}$ & $\mathbf{Q}$ & $\mathbf{N}^{0} \mathbf{L}$ & $\mathbf{Q}$ & $\mathbf{N}^{\circ} \mathbf{L}$ \\
\hline EUAN & $47.909,20$ & 8 & 346,15 & 16 & 120,67 & 10 & $1.080,78$ & 38 & 174,70 & 110 & $49.631,50$ & 182 \\
\hline Argentina & & & 38,00 & 2 & 952,01 & 20 & 154,58 & 12 & 774,76 & 22 & $1.919,35$ & 56 \\
\hline Chile & 14,88 & 3 & 215,41 & 17 & 242,00 & 22 & 757,18 & 44 & 567,91 & 20 & $1.797,38$ & 106 \\
\hline França & & & & & & & 251,40 & 5 & & & 251,40 & 5 \\
\hline Espanha & & & & & & & 114,97 & 11 & & & 114,97 & 11 \\
\hline Portugal & & & & & 6,43 & 2 & 8,79 & 3 & 4,66 & 4 & 19,88 & 9 \\
\hline Colômbia & & & & & & & & & 10,27 & 1 & 10,27 & 1 \\
\hline Alemanha & 2,16 & 1 & & & & & & & & & 2,16 & 1 \\
\hline China & & & $\overline{0,84}$ & 1 & 1,05 & 1 & & & & & 1,89 & 2 \\
\hline Holanda & & & & & & & 0,76 & 2 & & & 0,76 & 2 \\
\hline
\end{tabular}

Fonte: Brasil (1996) 
Tabela 9. Volume das importações de framboesas pelo Brasil em toneladas (Q) e número de lotes importados ( $\left.{ }^{\circ} \mathrm{L}\right)$ de janeiro de 1992 a agosto de 1996.

\begin{tabular}{|c|c|c|c|c|c|c|c|c|c|c|c|c|}
\hline \multirow{2}{*}{$\begin{array}{c}\text { País } \\
\text { exportador }\end{array}$} & \multicolumn{2}{|c|}{1992} & \multicolumn{2}{|c|}{1993} & \multicolumn{2}{|c|}{1994} & \multicolumn{2}{|c|}{1995} & \multicolumn{2}{|c|}{1996} & \multicolumn{2}{|c|}{ Total } \\
\hline & $\mathbf{Q}$ & $\mathbf{N}^{\circ} \mathbf{L}$ & $\mathbf{Q}$ & $\mathbf{N}^{\circ} \mathbf{L}$ & $\mathbf{Q}$ & $\mathbf{N}^{\circ} \mathbf{L}$ & $\mathbf{Q}$ & $\mathbf{N}^{0} \mathbf{L}$ & $\mathbf{Q}$ & $\mathbf{N}^{0} \mathbf{L}$ & $\mathbf{Q}$ & $\mathbf{N}^{0} \mathbf{L}$ \\
\hline Chile & & & 1,31 & 6 & 2,05 & 13 & 2,15 & 18 & 0,4 & 1 & 5,67 & 36 \\
\hline EUAN & & & & & 0,19 & 2 & 0,62 & 9 & 0,60 & 13 & 1,41 & 24 \\
\hline Holanda & & & & & & & 0,2 & 1 & & & 0,2 & 1 \\
\hline China & & & & & 0,08 & 1 & & & & & 0,08 & 1 \\
\hline Itália & & & & & & & 0,05 & 1 & & & 0,05 & 1 \\
\hline França & & & & & & & 0,004 & 1 & & & 0,004 & 1 \\
\hline
\end{tabular}

Fonte: Brasil (1996)

Tabela 10. Volume das importações de nectarinas pelo Brasil em toneladas (Q) e número de lotes importados ( $\left.{ }^{\circ} \mathrm{L}\right)$ de janeiro de 1992 a agosto de 1996.

\begin{tabular}{|c|c|c|c|c|c|c|c|c|c|c|c|c|}
\hline \multirow{2}{*}{$\begin{array}{c}\text { País } \\
\text { exportador }\end{array}$} & \multicolumn{2}{|l|}{1992} & \multicolumn{2}{|c|}{1993} & \multicolumn{2}{|c|}{1994} & \multicolumn{2}{|c|}{1995} & \multicolumn{2}{|c|}{1996} & \multicolumn{2}{|c|}{ Total } \\
\hline & $\mathbf{Q} \quad \mathbf{N}^{\circ}$ & & $\mathbf{Q}$ & $N^{0} \mathbf{L}$ & $\mathbf{Q}$ & $\mathbf{N}^{\circ} \mathbf{L}$ & $\mathbf{Q} \quad \mathbf{N}$ & $\gamma^{\circ} \mathbf{L}$ & $\mathbf{Q}$ & $\mathbf{N}^{\circ} \mathbf{L}$ & $\mathbf{Q}$ & $\mathbf{N}^{\circ} \mathbf{L}$ \\
\hline EUAN & $12.771,30$ & 9 & 112,37 & 16 & 56,47 & 11 & 586,83 & 42 & 137,04 & 108 & $13.664,01$ & 186 \\
\hline Chile & 39,02 & 4 & $9.022,06$ & 21 & 348,74 & 31 & 389,04 & 41 & 691,97 & 16 & $10.490,83$ & 113 \\
\hline Argentina & 16,32 & 1 & & & 17,32 & 2 & & & 38,83 & 7 & 72,47 & 10 \\
\hline Portugal & & & & & 0,47 & 1 & 7,86 & 6 & 2,30 & 2 & 10,63 & 9 \\
\hline Espanha & & & & & & & 7,24 & 6 & 3,10 & 3 & 10,34 & 9 \\
\hline Holanda & & & & & & & 3,12 & 2 & & & 3,12 & 2 \\
\hline Uruguai & & & & & & & & & 0,42 & 1 & 0,42 & 1 \\
\hline Franca & & & & & & & 0,01 & 1 & & & 0.01 & 1 \\
\hline
\end{tabular}

Fonte: Brasil (1996) 
Tabela 11. Volume das importações de rosas pelo Brasil em unidades (Q) e número de lotes importados ( $\left.\mathrm{N}^{\circ} \mathrm{L}\right)$ de janeiro de 1992 a agosto de 1996.

\begin{tabular}{|c|c|c|c|c|c|c|c|c|c|c|c|c|}
\hline \multirow{2}{*}{$\begin{array}{c}\text { País } \\
\text { exportador }\end{array}$} & \multicolumn{2}{|c|}{1992} & \multicolumn{2}{|c|}{1993} & \multicolumn{2}{|c|}{1994} & \multicolumn{2}{|c|}{1995} & \multicolumn{2}{|c|}{1996} & \multicolumn{2}{|l|}{ Total } \\
\hline & $\mathbf{Q}$ & $\mathbf{N}^{\circ} \mathbf{L}$ & $\mathbf{Q}$ & $\mathbf{N}^{o} \mathbf{L}$ & $\mathbf{Q}$ & $\mathbf{N}^{\circ} \mathbf{L}$ & $\mathbf{Q}$ & $\mathbf{N}^{0} \mathbf{L}$ & $\mathbf{Q}$ & $\mathbf{N}^{0} \mathbf{L}$ & $\mathbf{Q}$ & $\mathbf{N}^{0} \mathbf{L}$ \\
\hline Holanda & 69 & 1 & 300 & 1 & & & 5.725 & 3 & & & 6.094 & 5 \\
\hline Uruguai & & & & & & & & & 17.704 & 5 & 17.704 & 5 \\
\hline Colômbia & & & 42 & 1 & 784 & 1 & & & 275.882 & 31 & 276.708 & 33 \\
\hline Equador & & & & & & & & & 74.544 & 36 & 74.544 & 36 \\
\hline Chile & & & & & & & 476 & 1 & & & 476 & 1 \\
\hline EUAN & 3 & 1 & & & & & & & & & 3 & 1 \\
\hline Guiana Francesa & 1 & 1 & & & & & & & & & 1 & 1 \\
\hline
\end{tabular}

Fonte: Brasil (1996)

Tabela 12. Volume das importações de mudas de roseiras pelo Brasil em unidades (Q) e número de lotes importados ( $\left.\mathrm{N}^{\circ} \mathrm{L}\right)$ de janeiro de 1992 a agosto de 1996.

\begin{tabular}{|c|c|c|c|c|c|c|c|c|c|c|c|c|}
\hline \multirow{2}{*}{$\begin{array}{c}\text { País } \\
\text { exportador }\end{array}$} & \multicolumn{2}{|c|}{1992} & \multicolumn{2}{|c|}{1993} & \multicolumn{2}{|c|}{1994} & \multicolumn{2}{|c|}{1995} & \multicolumn{2}{|c|}{1996} & \multicolumn{2}{|c|}{ Total } \\
\hline & $\mathbf{Q}$ & $\mathbf{N}^{\circ} \mathbf{L}$ & $\mathbf{Q}$ & $\mathbf{N}^{\circ} \mathbf{L}$ & Q 1 & $\mathbf{N}^{0} \mathbf{L}$ & & $\mathbf{N}^{\circ} \mathbf{L}$ & $\mathbf{Q}$ & $\mathbf{N}^{0} \mathbf{L}$ & $\mathbf{Q}$ & $\mathbf{N}^{\circ} \mathbf{L}$ \\
\hline Alemanha & & & 85.000 & 1 & 1.500 & 1 & 40.000 & 1 & & & 126.500 & 3 \\
\hline Colômbia & & & 19.310 & 13 & 25.195 & 2 & & & & & 44.505 & 15 \\
\hline Holanda & & & 8.000 & 1 & & & 1.008 & 1 & & & 9.008 & 2 \\
\hline EUAN & & & 1.710 & 1 & 3.504 & 1 & & & & & 5.214 & 2 \\
\hline Áustria & 54.000 & 1 & & & & & & & & & 54.000 & 1 \\
\hline
\end{tabular}

Fonte: Brasil (1996) 
Tabela 13. Volume das importações de melões pelo Brasil em toneladas $(Q)$ e número de lotes importados $\left(\mathrm{N}^{\circ} \mathrm{L}\right)$ de janeiro de 1992 a agosto de 1996.

\begin{tabular}{|c|c|c|c|c|c|c|c|c|c|c|c|c|}
\hline \multirow{2}{*}{$\begin{array}{c}\text { País } \\
\text { exportador }\end{array}$} & \multicolumn{2}{|c|}{1992} & \multicolumn{2}{|c|}{1993} & \multicolumn{2}{|c|}{1994} & \multicolumn{2}{|c|}{1995} & \multicolumn{2}{|c|}{1996} & \multicolumn{2}{|c|}{ Total } \\
\hline & Q & $\mathbf{N}^{\circ} \mathbf{L}$ & $\mathbf{Q}$ & $\mathbf{N}^{\circ} \mathbf{L}$ & $\mathbf{Q}$ & $\mathbf{N}^{0} \mathbf{L}$ & $\mathbf{Q}$ & $\mathbf{N}^{0} \mathbf{L}$ & $\mathbf{Q}$ & $\mathbf{N}^{0} \mathbf{L}$ & $\mathbf{Q}$ & $\mathbf{N}^{0} \mathbf{L}$ \\
\hline Holanda & & & 477,46 & 4 & & & & & & & 477,46 & 4 \\
\hline Inglaterra & & & $1.094,7$ & 5 & & & & & & & $1.094,7$ & 5 \\
\hline Dinamarca & & & 8,42 & 1 & & & & & & & 8,42 & 1 \\
\hline Alemanha & & & 17,94 & 1 & & & & & & & 17,94 & 1 \\
\hline Argentina & & & 12.600 & 1 & 17,46 & 1 & & & & & $12.617,46$ & 2 \\
\hline Franca & & & & & & & 0,015 & 1 & & & 0,015 & 1 \\
\hline EUAN & 0,49 & 1 & & & 0,26 & 1 & 0,2 & 1 & 2,07 & 4 & 3,02 & 7 \\
\hline Chile & & & & & 2,82 & 3 & 2,85 & 5 & & & 5,67 & 8 \\
\hline Espanha & & & & & & & 0,03 & 1 & & & 0,03 & 1 \\
\hline
\end{tabular}

Fonte: Brasil (1996)

Tabela 14. Volume das importações de amoras pelo Brasil em toneladas $(\mathrm{Q})$ e número de lotes importados ( $\left.\mathrm{N}^{\circ} \mathrm{L}\right)$ de janeiro de 1992 a agosto de 1996.

\begin{tabular}{|c|c|c|c|c|c|c|c|c|c|c|c|c|}
\hline \multirow{2}{*}{$\begin{array}{c}\text { País } \\
\text { exportador }\end{array}$} & \multicolumn{2}{|c|}{1992} & \multicolumn{2}{|c|}{1993} & \multicolumn{2}{|c|}{1994} & \multicolumn{2}{|c|}{1995} & \multicolumn{2}{|c|}{1996} & \multicolumn{2}{|c|}{ Total } \\
\hline & Q & $\mathbf{N}^{\circ} \mathbf{L}$ & $\mathbf{Q}$ & $\mathbf{N}^{0} \mathbf{L}$ & $\mathbf{Q}$ & $N^{a} \mathbf{L}$ & & $\mathbf{N}^{0} \mathbf{L}$ & $\mathbf{Q}$ & $\mathbf{N}^{0} \mathbf{L}$ & $\mathbf{Q}$ & $\mathbf{N}^{\circ} \mathbf{L}$ \\
\hline México & & & & & & & 22,01 & 1 & & & 22,01 & 1 \\
\hline Chile & & & 4,81 & 9 & 2,93 & 11 & 0,32 & 6 & & & 8,06 & 26 \\
\hline EUAN & & & & & & & 2,28 & 5 & 0,55 & 11 & 2,83 & 16 \\
\hline Canadá & & & & & & & $\overline{2,27}$ & 3 & & & 2,27 & 3 \\
\hline
\end{tabular}

Fonte: Brasil (1996) 
Tabela 15. Volume das importações de morangos pelo Brasil em toneladas (Q) e número de lotes importados ( $\left.{ }^{\circ} \mathrm{L}\right)$ de janeiro de 1992 a agosto de 1996.

\begin{tabular}{|c|c|c|c|c|c|c|c|c|c|c|c|c|}
\hline \multirow{2}{*}{$\begin{array}{c}\text { País } \\
\text { exportador }\end{array}$} & \multicolumn{2}{|c|}{1992} & \multicolumn{2}{|c|}{1993} & \multicolumn{2}{|c|}{1994} & \multicolumn{2}{|c|}{1995} & \multicolumn{2}{|c|}{1996} & \multicolumn{2}{|l|}{ Total } \\
\hline & $\mathbf{Q}$ & $\mathbf{N}^{0} \mathbf{L}$ & & $\mathbf{N}^{0} \mathbf{L}$ & $\mathbf{Q}$ & $\mathbf{N}^{\circ} \mathbf{L}$ & & $\mathbf{N}^{\circ} \mathbf{L}$ & $\mathbf{Q}$ & $N^{\circ} \mathbf{L}$ & $\mathbf{Q}$ & $N^{a} L$ \\
\hline EUAN & & & & & 34,86 & 10 & 186,95 & 55 & 13,92 & 22 & 235,73 & 87 \\
\hline Chile & 0,001 & 1 & 0,5 & 1 & 17,56 & 14 & 35,3 & 23 & & & 53,36 & 40 \\
\hline Espanha & & & & & & & 43,96 & 12 & & & 43,96 & 12 \\
\hline Portugal & & & & & & & 40,93 & 13 & & & 40,93 & 13 \\
\hline Colômbia & & & & & & & 9,54 & 8 & & & 9,54 & 8 \\
\hline Reino Unido & & & & & & & 1,95 & 2 & & & 1,95 & 2 \\
\hline Alemanha & & & & & 1,6 & 1 & & & & & 1,6 & 1 \\
\hline México & & & & & & & 0,01 & 1 & & & 0,01 & 1 \\
\hline Uruguai & 0,004 & 1 & & & & & & & & & 0,004 & 1 \\
\hline
\end{tabular}

Fonte: Brasil (1996) 


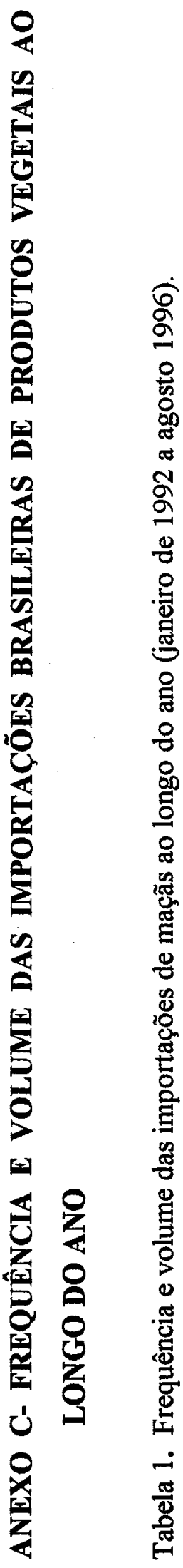

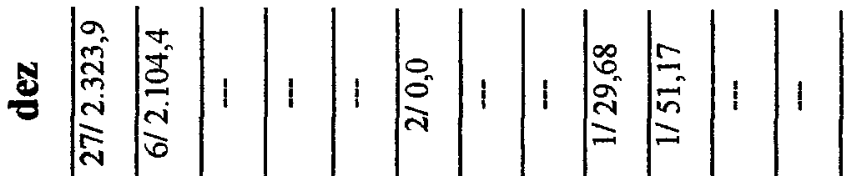

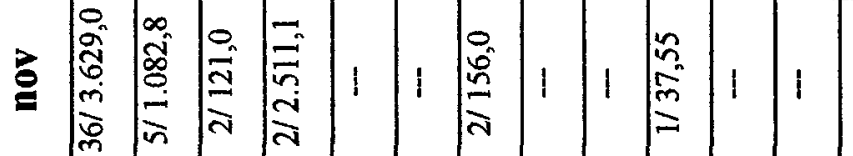

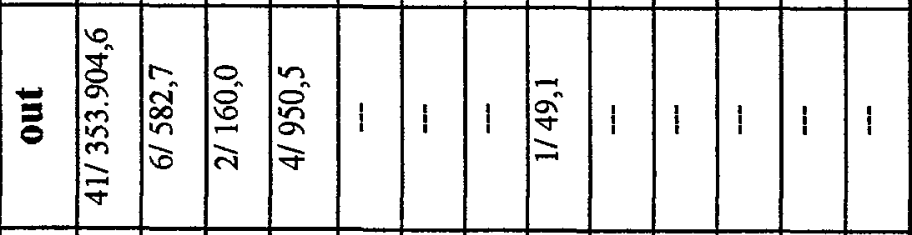

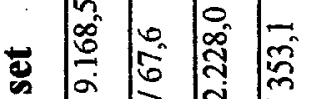

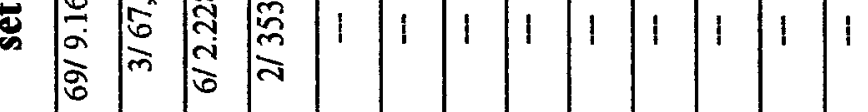

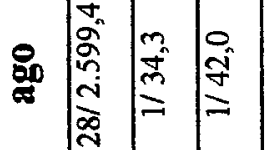

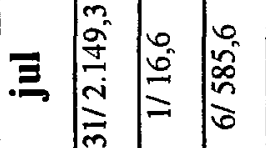

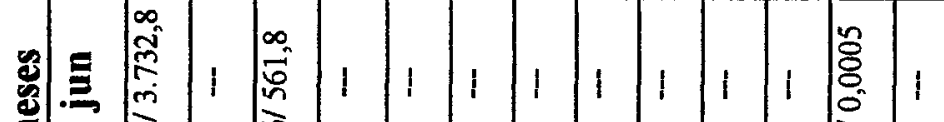

$=$

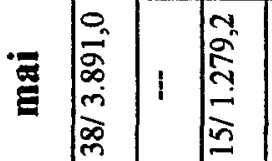

\begin{tabular}{|c|c|c|c|c|c|c|c|c|c|c|c|}
\hline ప & $\begin{array}{l}\infty \\
\infty \\
\infty \\
\equiv\end{array}$ & $\frac{0}{m}$ & 1 & $\mid \begin{array}{l}0 \\
8 \\
8 \\
0\end{array}$ & 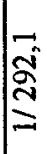 & 1 & 1 & 1 & 1 & $\begin{array}{l}\infty \\
\infty \\
\infty \\
=\end{array}$ & 1 \\
\hline
\end{tabular}

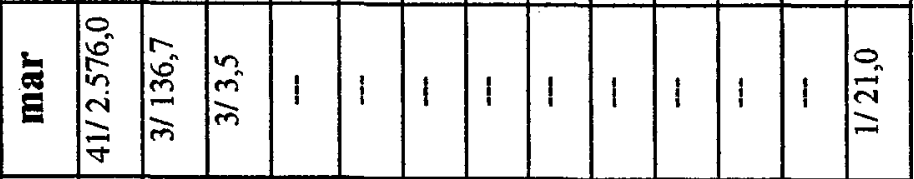

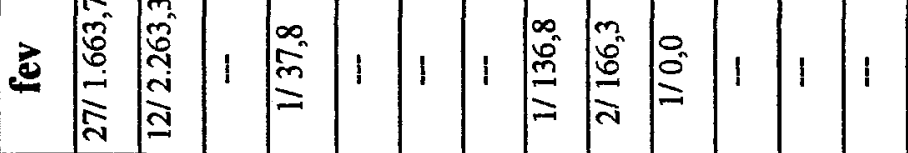

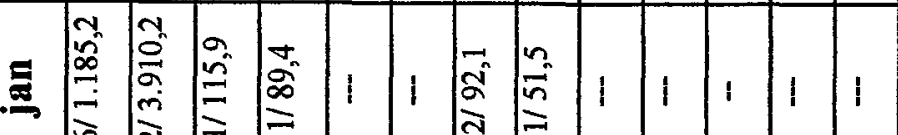

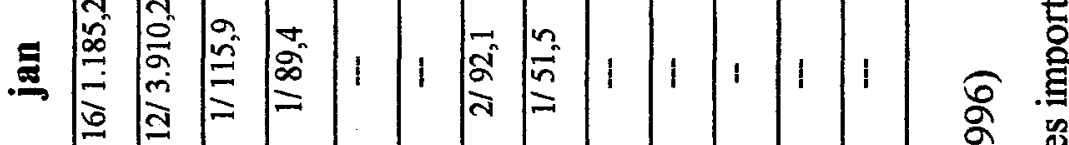

\begin{tabular}{|c|c|c|c|c|c|c|c|c|c|c|c|c|c|}
\hline 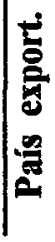 & 壱 & $\frac{2}{8}$ & $\frac{\mathscr{\theta}}{0}$ & 㿣 & 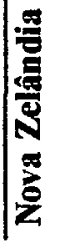 & 吾 & 量 & 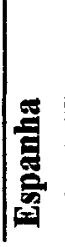 & 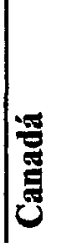 & 焉 & 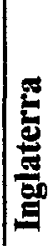 & 昜 & 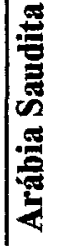 \\
\hline
\end{tabular}

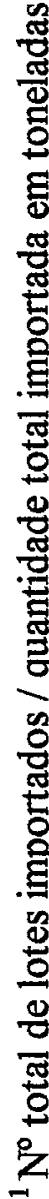




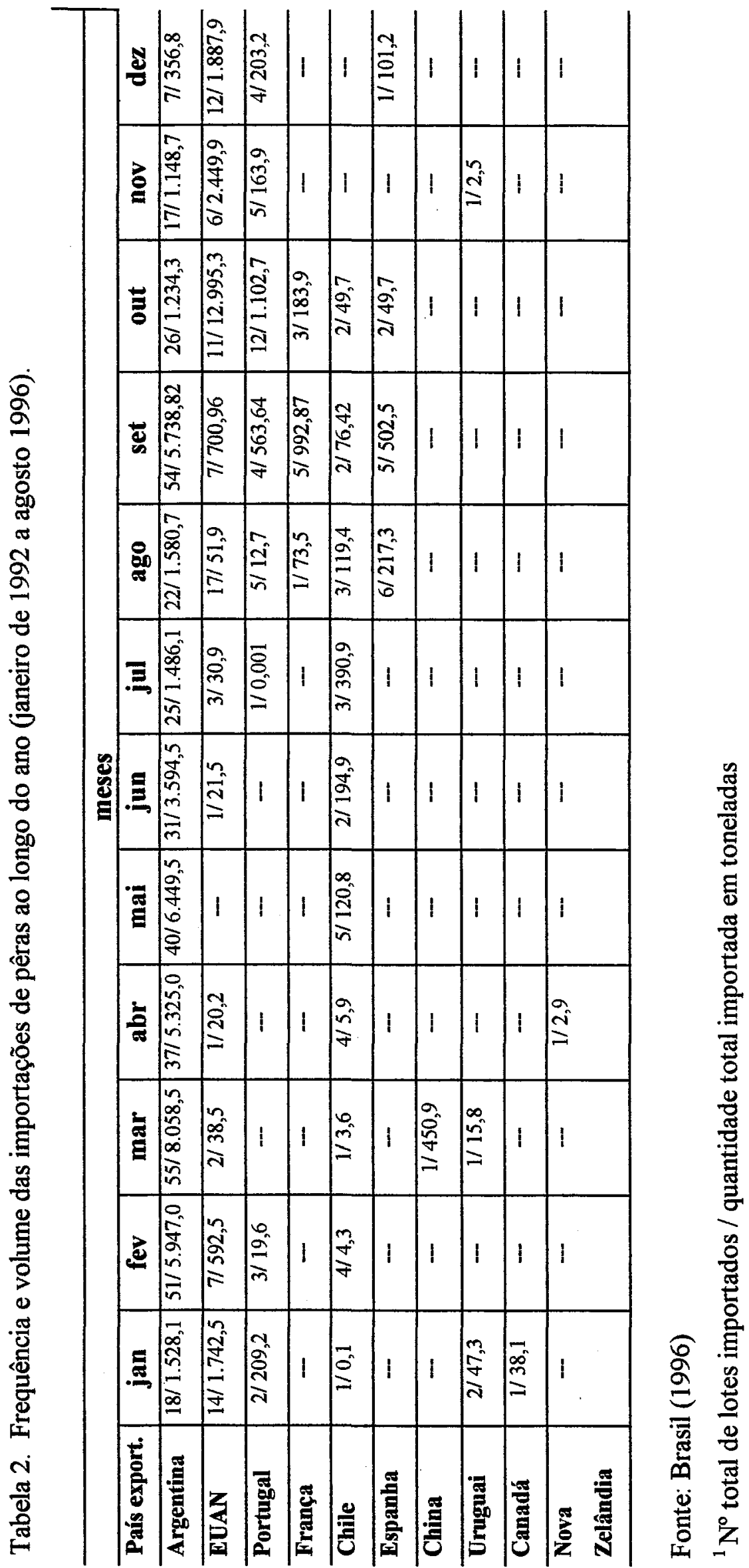




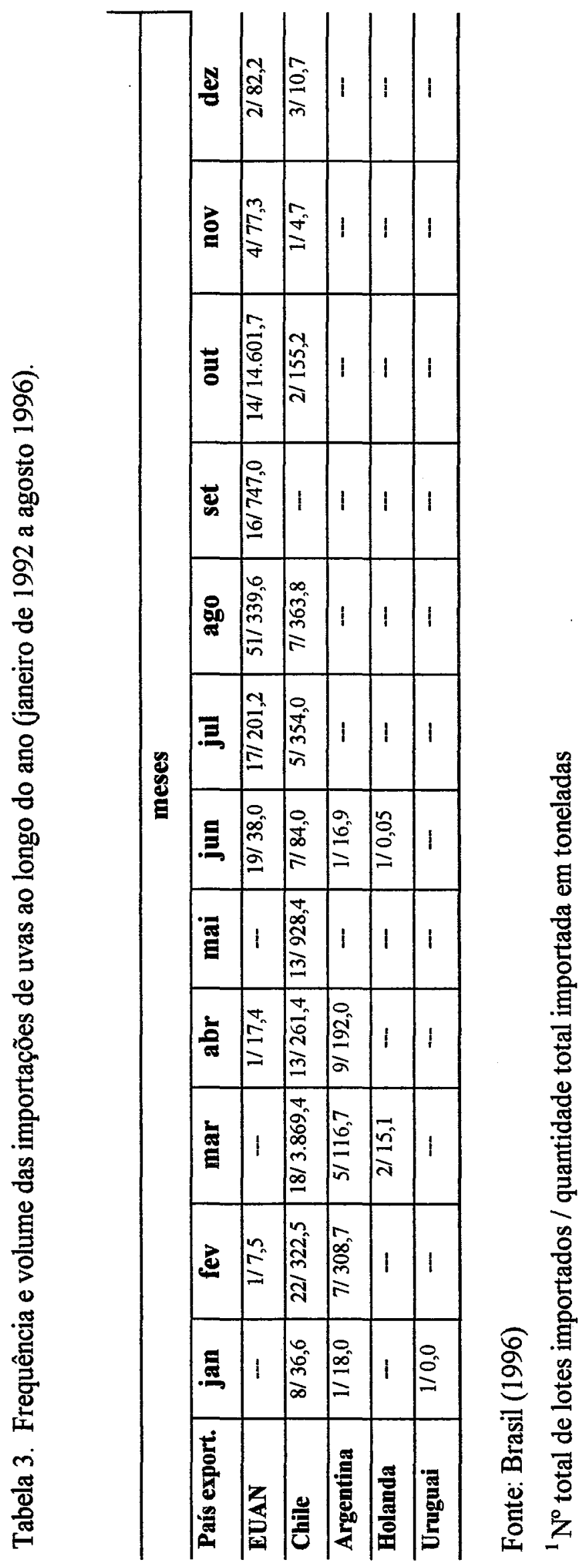




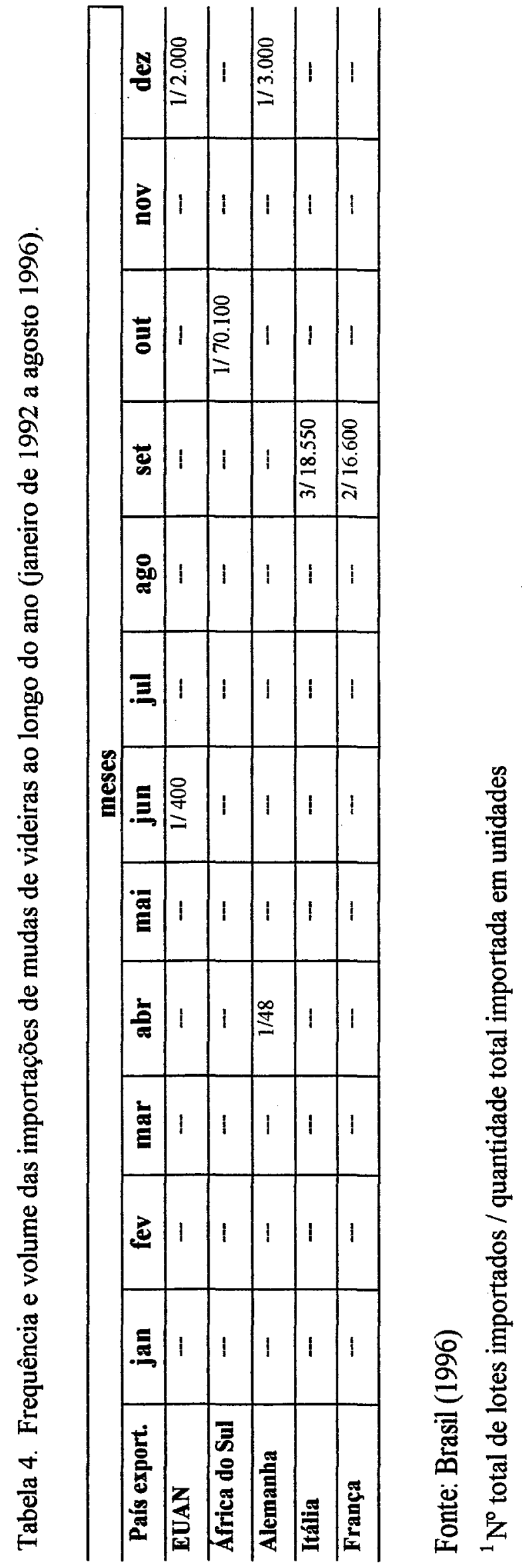




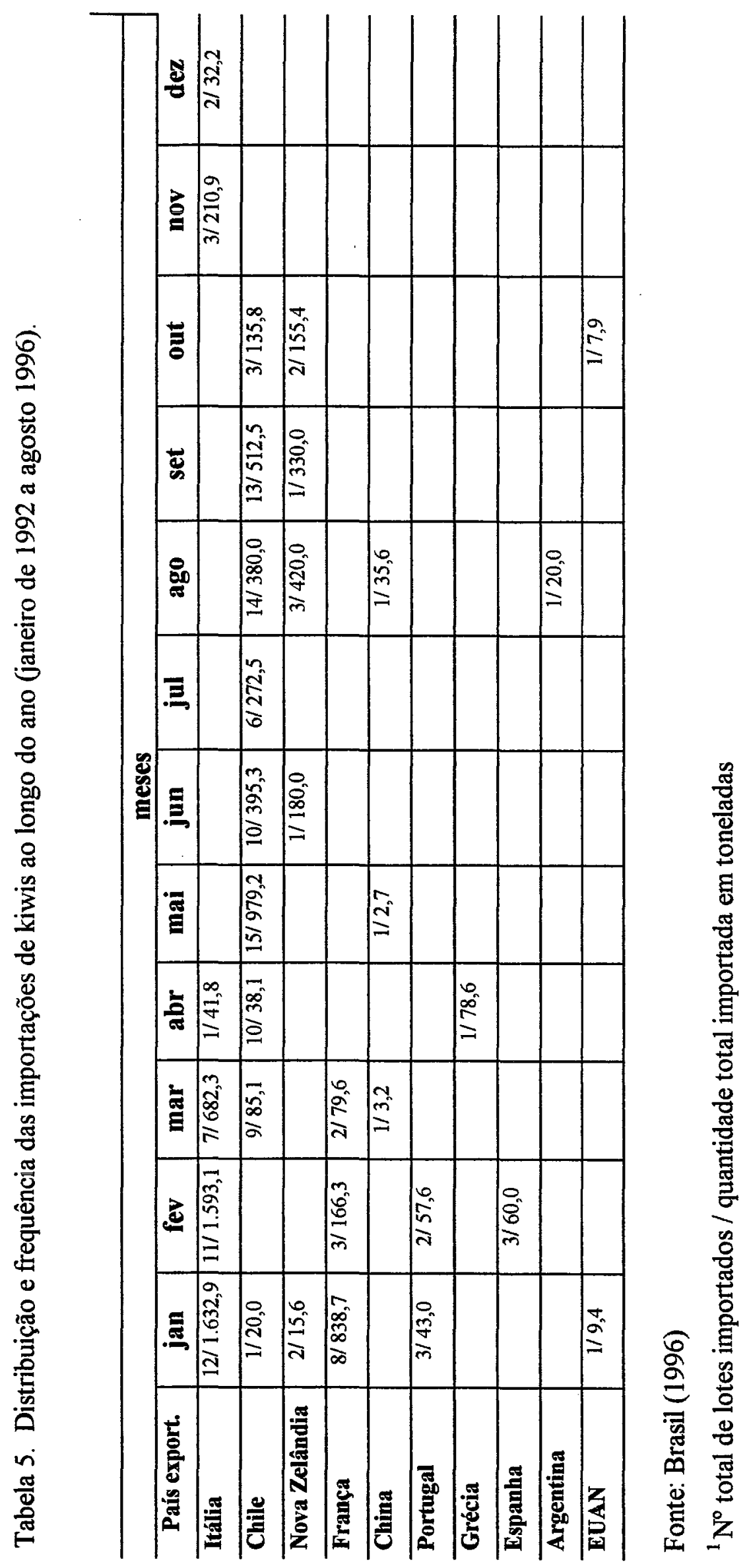




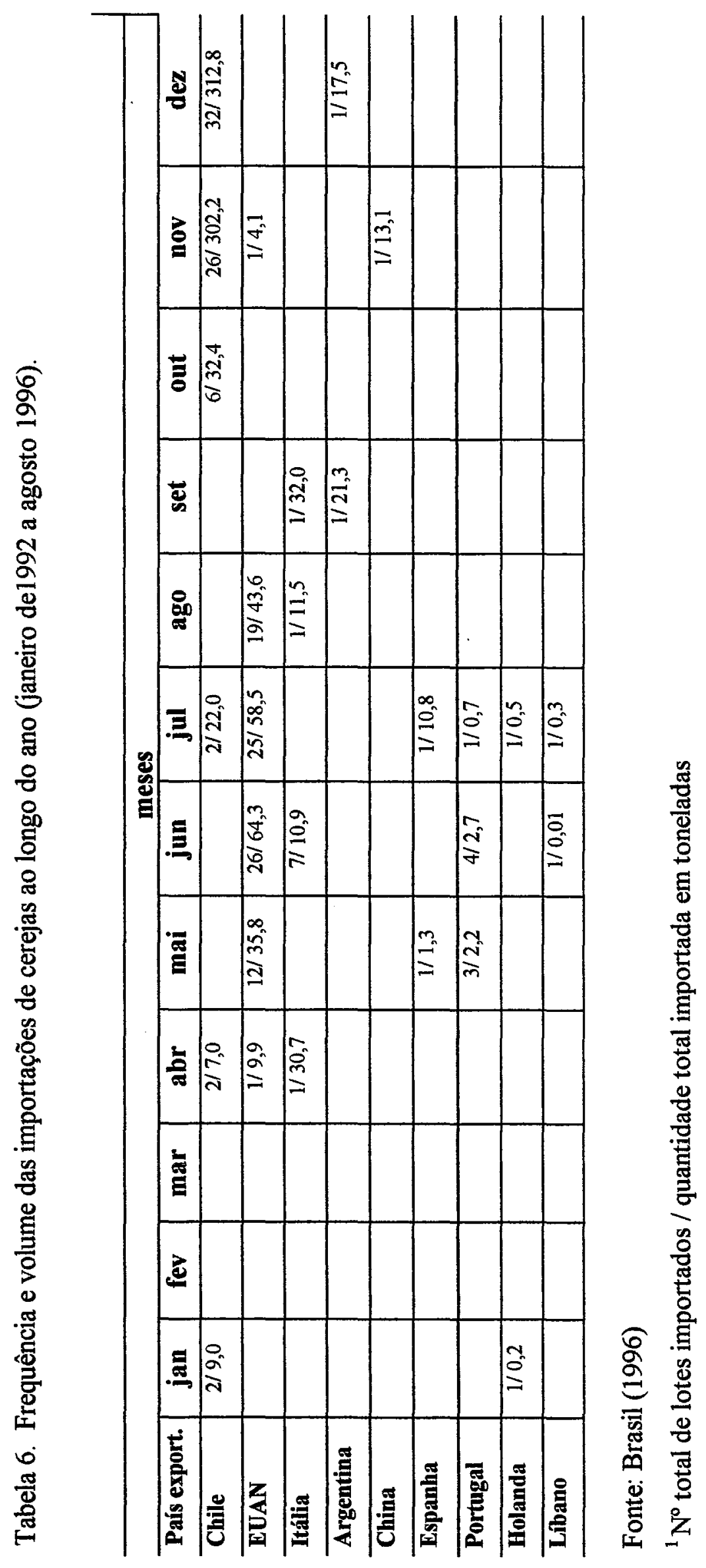




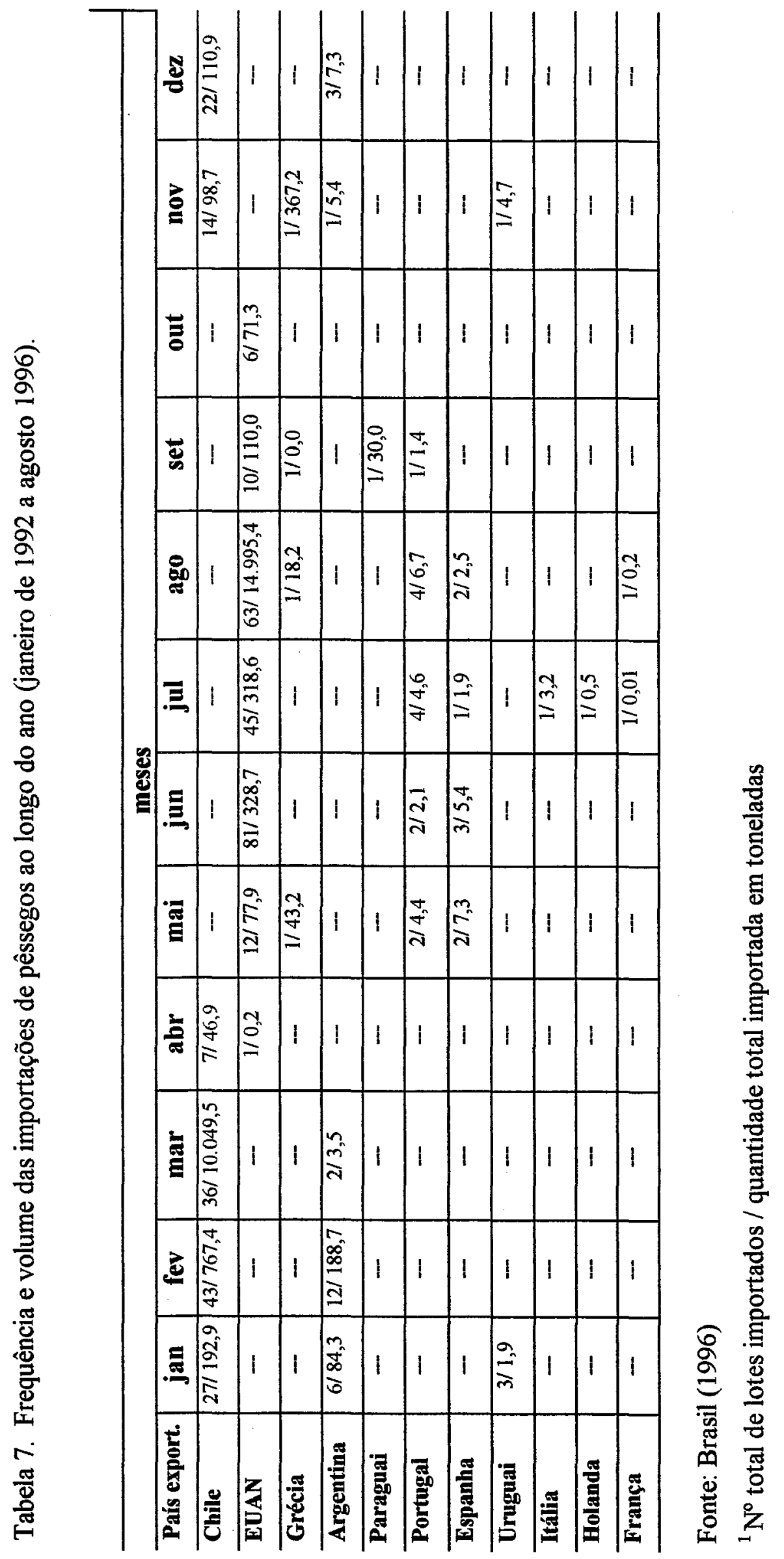




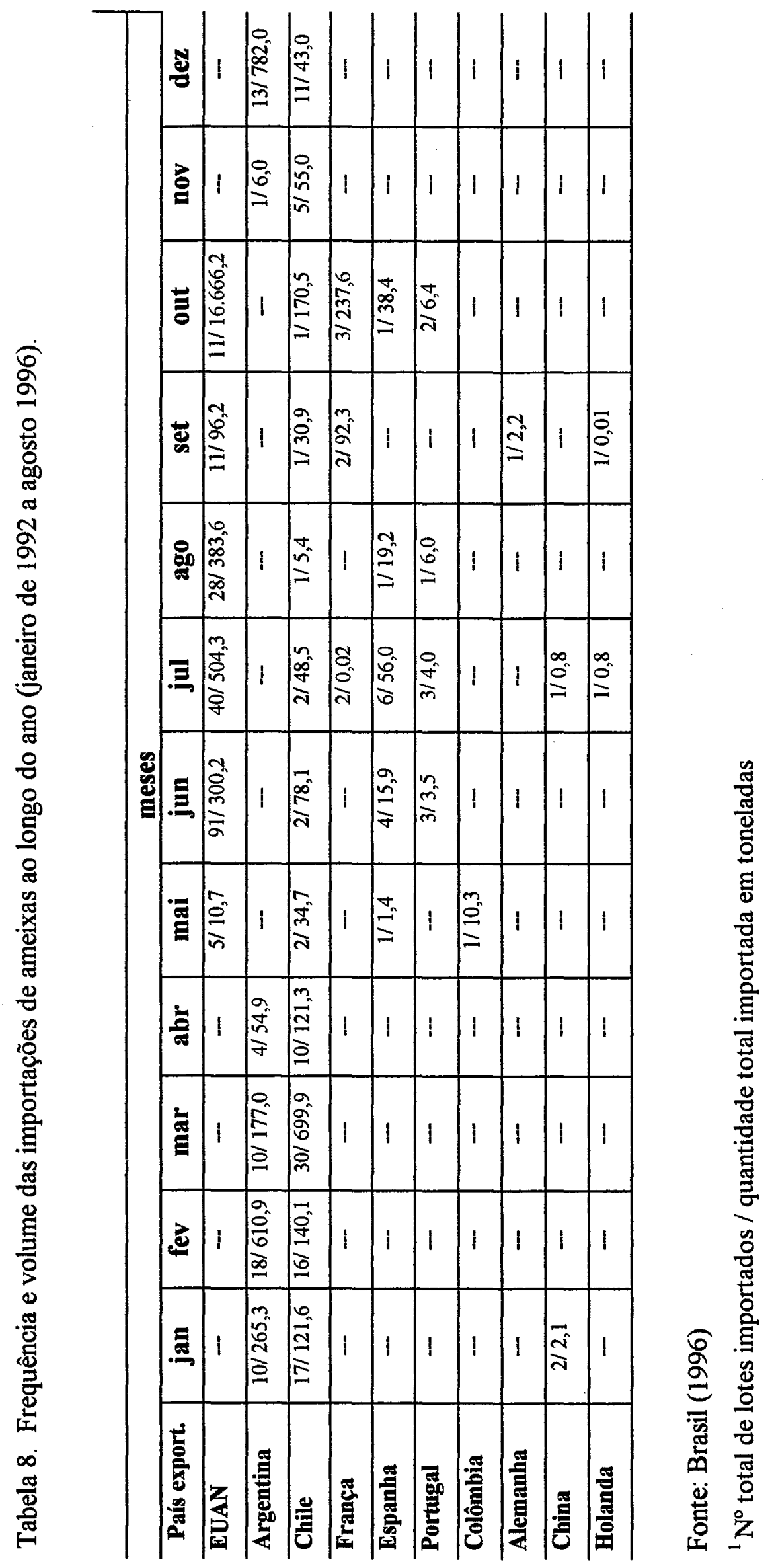




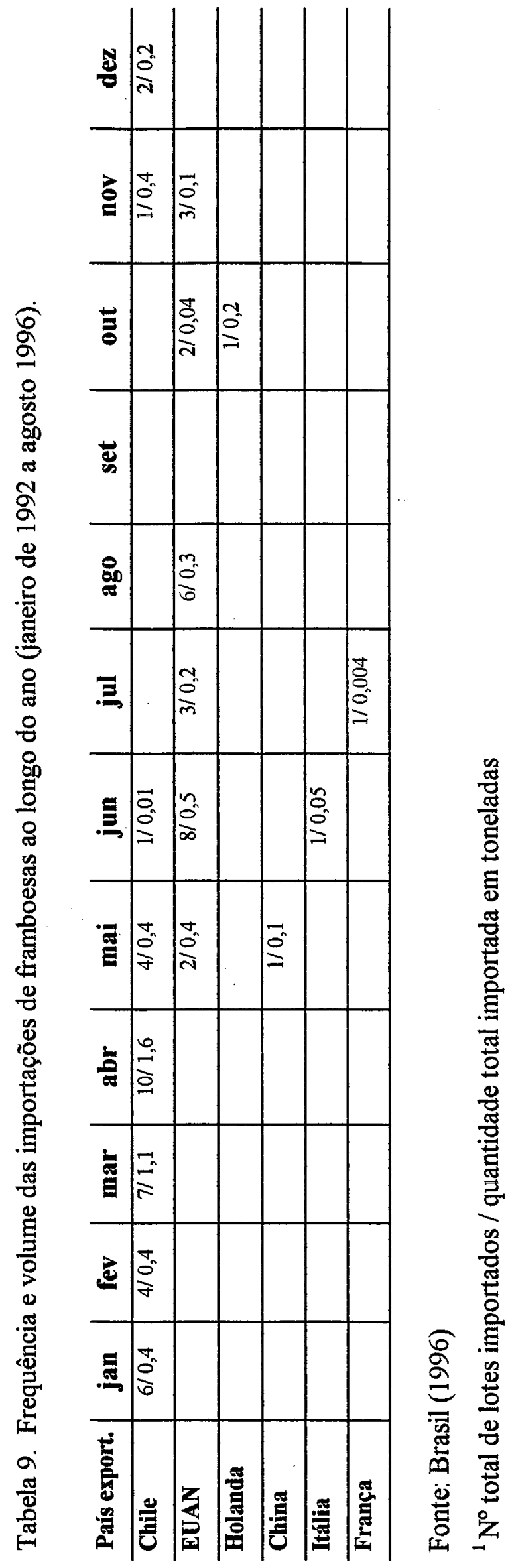




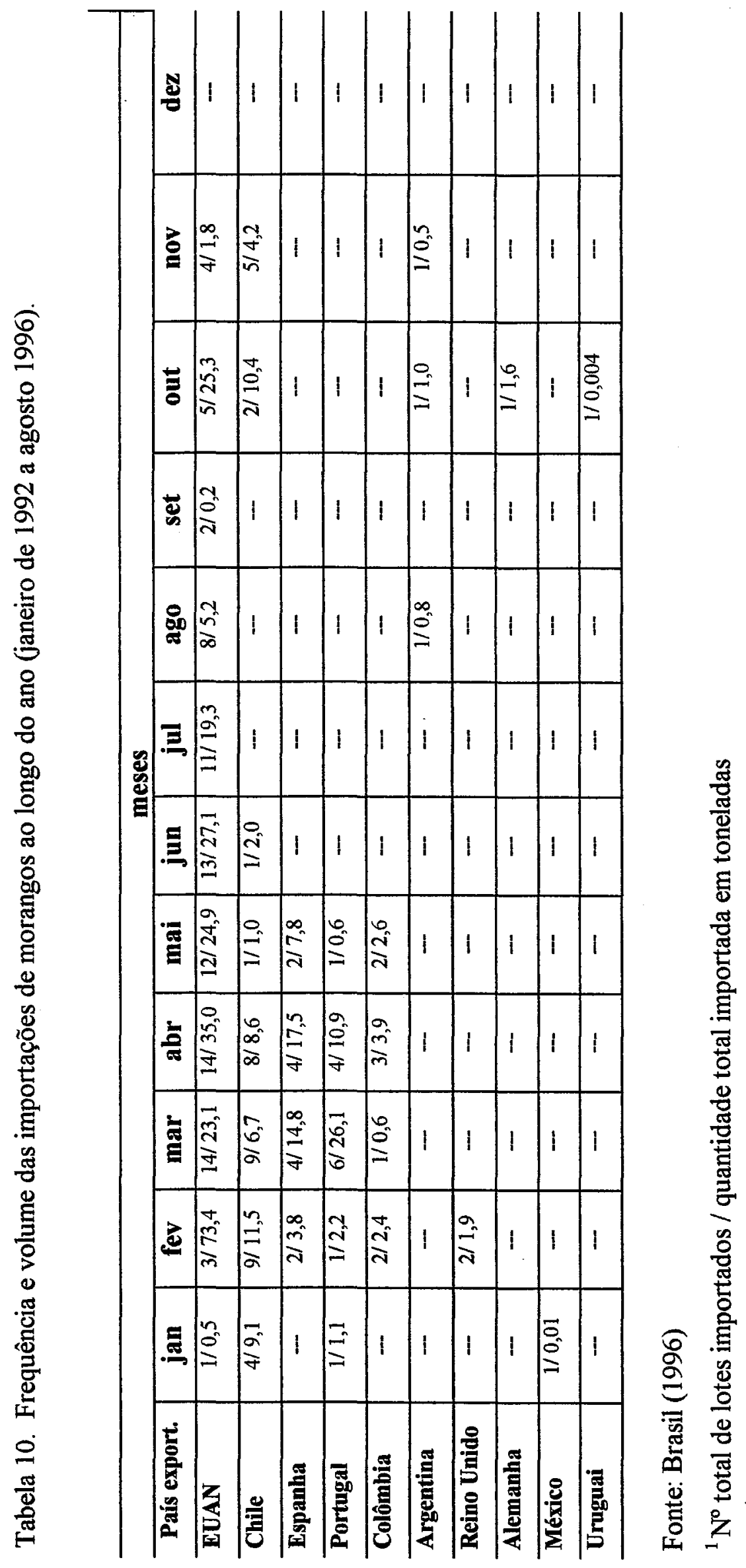




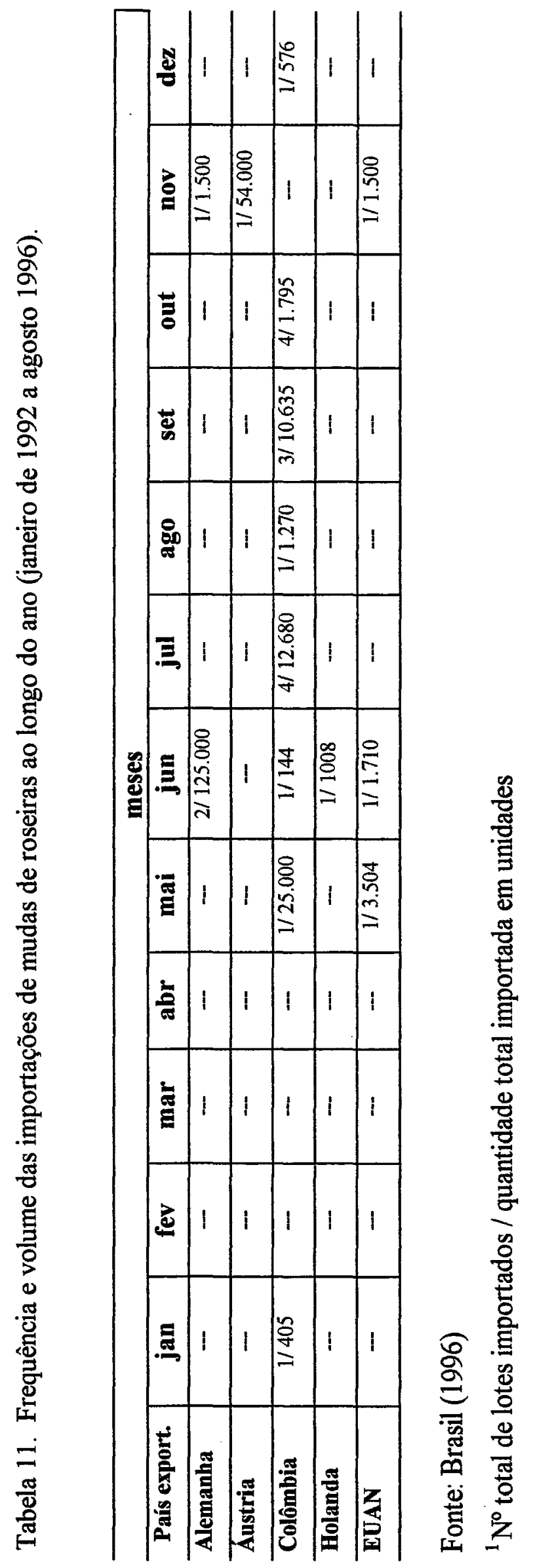




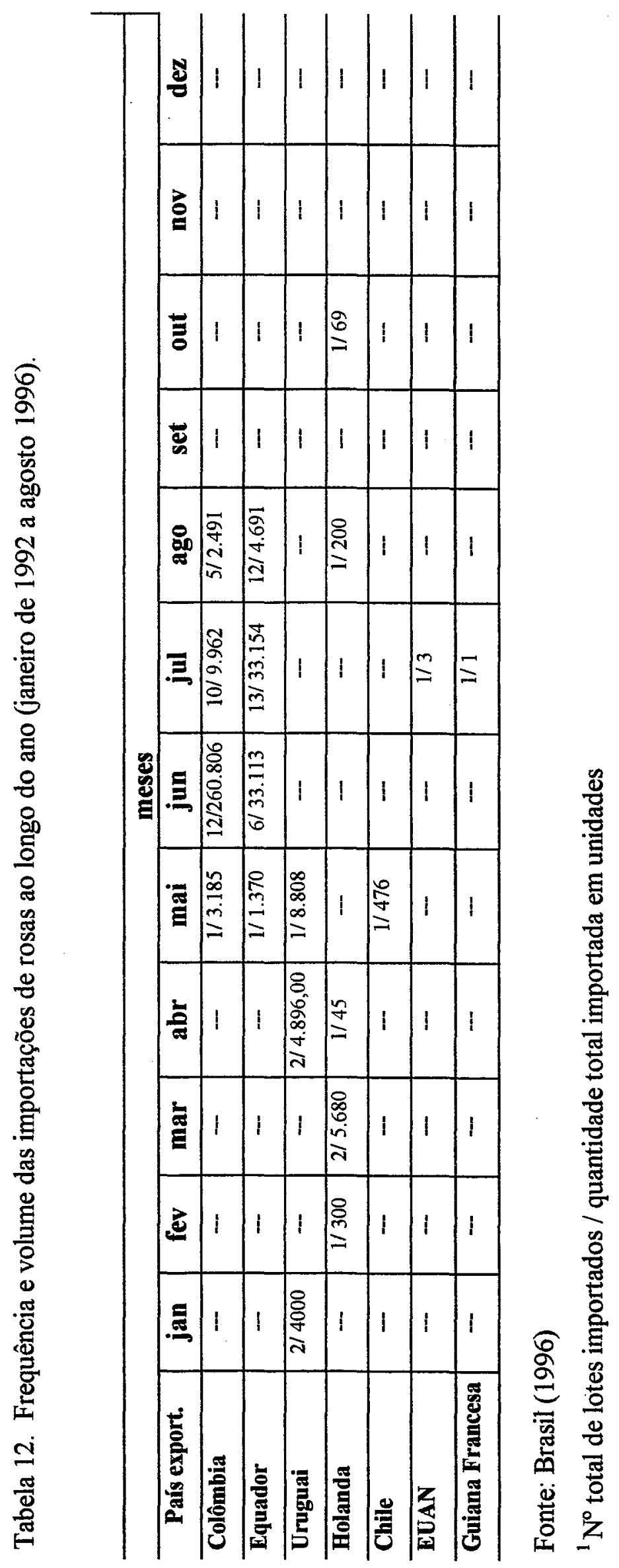




\section{ANEXO D- DESTINO DAS IMPORTAÇÕES BRASILEIRAS DE PRODUTOS VEGETAIS}

Tabela 1. Destino final de maçãs importadas pelo Brasil de janeiro de1992 a agosto de 1996, por país exportador.

\begin{tabular}{|c|c|c|c|c|}
\hline País exportador & Destino final & Chegada & Quantidade (t) & Porcentagem \\
\hline \multirow[t]{11}{*}{ Argentina } & $\mathbf{A L}$ & $\overline{\mathrm{PR}}$ & 19,0 & 0,005 \\
\hline & $\mathbf{B A}$ & PR & 20,0 & 0,005 \\
\hline & DF & PR & 111,4 & 0,03 \\
\hline & $\mathbf{E S}$ & RS, PR & 502,2 & 0,1 \\
\hline & MG & PR & 311,1 & 0,1 \\
\hline & $\overline{\mathbf{P E}}$ & $\mathrm{PB}, \mathrm{PE}$ & $351.046,1$ & 90,5 \\
\hline & PR & $\mathrm{PR}, \mathrm{CE}, \mathrm{SC}$ & $4.600,7$ & 1,2 \\
\hline & $\overline{\mathbf{R J}}$ & RS, PR & $1.963,2$ & 0,5 \\
\hline & $\overline{\mathbf{R S}}$ & RS, PR & $8.544,8$ & 2,2 \\
\hline & $\mathbf{S C}$ & $\overline{\mathrm{SC}, \mathrm{RS}, \mathrm{PR}}$ & $1.223,4$ & 0,3 \\
\hline & $\mathbf{S P}$ & PR, RS, CE & $19.588,5$ & 5,1 \\
\hline \multirow[t]{8}{*}{ EUAN } & $\overline{\mathbf{A M}}$ & $\overline{A M}$ & 316,2 & 3,1 \\
\hline & ES & RJ, PR & 194,5 & 1,9 \\
\hline & MG & MG, PR & 284,5 & 2,8 \\
\hline & $\overline{\mathbf{P A}}$ & PA & 36,0 & 0,3 \\
\hline & $\overline{\text { PR }}$ & $\overline{\mathrm{PR}}$ & 944,9 & 9,3 \\
\hline & $\mathbf{R J}$ & PR & 193,7 & 1,9 \\
\hline & $\mathbf{S C}$ & SC, PR & $1.944,4$ & 19,0 \\
\hline & SP & $\mathrm{SP}, \mathrm{RJ}, \mathrm{PR}$ & $6.302,5$ & 61,7 \\
\hline \multirow[t]{5}{*}{ Chile } & PR & PR & 614,6 & 11,5 \\
\hline & $\mathbf{R J}$ & RJ, PR & 184,4 & 3,5 \\
\hline & RS & RS & 30,7 & 0,6 \\
\hline & SC & $\mathrm{PR}$ & 312,0 & 5,8 \\
\hline & $\mathbf{S P}$ & RJ, RS, PR, SP & $4.205,5$ & 78,6 \\
\hline \multirow[t]{2}{*}{ Holanda } & SC & $\overline{P R}$ & 292,1 & $\overline{99,9}$ \\
\hline & $\mathbf{S P}$ & SP & 0,04 & 0,01 \\
\hline \multirow[t]{3}{*}{ Hungria } & $\mathbf{B A}$ & $\mathrm{RJ}$ & 53,1 & 21,4 \\
\hline & $\overline{\mathbf{P E}}$ & $\mathrm{PE}$ & 156,0 & 62,9 \\
\hline & SP & SP & 39,0 & 15,7 \\
\hline
\end{tabular}




\begin{tabular}{lllll}
\hline Espanha & SP & SP & 237,4 & 100 \\
\hline \multicolumn{1}{l}{ Canadá } & & & & \\
\hline & & & & \\
\hline Itália & RS & SC, PR & $\mathbf{8 8 , 7}$ & 99,9 \\
\hline & PE & PE & $\mathbf{0 , 0 1}$ & 0,01 \\
\hline & & & & \\
\hline Inglaterra & RS & PR & $\mathbf{3 8 , 8}$ & 100 \\
\hline
\end{tabular}

Fonte: Brasil (1996)

Tabela 2. Destino final de pêras importadas pelo Brasil de janeiro de1992 a agosto de 1996, por país exportador.

\begin{tabular}{|c|c|c|c|c|}
\hline País exportador & Destino final & Chegada & Quantidade (t) & Porcentagem \\
\hline \multirow[t]{9}{*}{ EUAN } & $\overline{\mathbf{A M}}$ & $\overline{\mathrm{AM}}$ & 121,6 & 0,6 \\
\hline & ES & $\mathrm{RJ}$ & 132,9 & 0,7 \\
\hline & $\overline{\mathbf{P A}}$ & $\overline{P A}$ & 9,3 & 0,05 \\
\hline & $\overline{\mathbf{P E}}$ & SP & 18,6 & 0,09 \\
\hline & $\overline{\mathbf{P R}}$ & SP, PR & $2.162,5$ & 10,5 \\
\hline & $\overline{\mathbf{R J}}$ & RJ, SP & 56,2 & 0,3 \\
\hline & $\mathbf{R S}$ & PR & 53,3 & 0,3 \\
\hline & SC & SC, PR & 789,0 & 3,8 \\
\hline & SP & SP, PR, & $17.191,7$ & 83,7 \\
\hline \multirow{4}{*}{ Portugal } & MG & MG & 8,3 & 0,4 \\
\hline & PR & $\mathrm{PR}$ & 66,0 & 2,9 \\
\hline & $\mathbf{R J}$ & $\mathrm{RJ}$ & 17,9 & 0,8 \\
\hline & $\mathbf{S P}$ & SP, PR & $2.182,9$ & 95,9 \\
\hline \multirow[t]{2}{*}{ França } & SC & PR & 361,0 & 28,9 \\
\hline & $\mathbf{S P}$ & SP & 889,3 & 71,1 \\
\hline China & PR & $\mathrm{SC}$ & 450,9 & 100 \\
\hline
\end{tabular}

Fonte: Brasil (1996) 
Tabela 3. Destino final de uvas importadas pelo Brasil de janeiro de1992 a agosto de 1996, por país exportador.

\begin{tabular}{lllll}
\hline País exportador & Destino final & Chegada & Quantidade (t) & Porcentagem \\
\hline EUAN & AM & AM & 198,6 & 1,2 \\
\hline & PA & PA & 7,5 & 0,05 \\
\hline PR & SP & 3,6 & 0,02 \\
\hline SP & SP & $15,806,1$ & 98,7 \\
\hline Chile & & & \\
\hline & ES & PR & 7,87 & 0,12 \\
\hline GO & SP & 109,13 & 1,69 \\
\hline MG & PR & 3,39 & 0,05 \\
\hline PR & PR, CE, SP & 327,99 & 5,09 \\
\hline RJ & SP, PR & 54,65 & 0,85 \\
\hline RS & RS & 139,48 & 2,16 \\
\hline SC & SC & 260,52 & 4,04 \\
\hline SP & SP, PR & $5.537,13$ & 85,98 \\
\hline
\end{tabular}

Fonte: Brasil (1996)

Tabela 4. Destino final de -mudas de videiras importadas pelo Brasil de janeiro de1992 a agosto de 1996, por país exportador.

\begin{tabular}{lllll}
\hline País exportador & Destino final & Chegada & Quantidade (un) & Porcentagem \\
\hline EUAN & BA & BA & 400 & 16,7 \\
\hline & RS & RS & 2.000 & 83,3 \\
\hline Itália & RS & RS & 18.550 & 100 \\
\hline & & & & \\
\hline França & RS & RS & 16.600 & 100 \\
\hline
\end{tabular}

Fonte: Brasil (1996) 
Tabela 5. Destino final de kiwis importadas pelo Brasil de janeiro de1992 a agosto de 1996, por país exportador.

\begin{tabular}{lllll}
\hline País exportador & Destino final & Chegada & Quantidade (t) & Porcentagem \\
\hline Chile & BA & BA & 0,1 & 0,003 \\
\hline & PR & PR, SP & 367,4 & 13,8 \\
\hline RJ & RJ, PR & 86,5 & 3,2 \\
\hline RS & RS & 99,3 & 3,7 \\
\hline SP & SP, PR, RS & $1,974,4$ & 73,4 \\
\hline
\end{tabular}

Fonte: Brasil (1996)

Tabela 6. Destino final de cerejas importadas pelo Brasil de janeiro de1992 a agosto de 1996, por país exportador.

\begin{tabular}{lllll}
\hline País exportador & Destino final & Chegada & Quantidade (t) & Porcentagem \\
\hline EUAN & PR & SP & 1,52 & 0,71 \\
\hline & RJ & SP & 3,21 & 1,5 \\
\hline SP & SP & 209,54 & 97,79 \\
\hline
\end{tabular}

Fonte: Brasil (1996) 
Tabela 7. Destino final de pêssegos importados pelo Brasil de janeiro de1992 a agosto de 1996, por país exportador.

\begin{tabular}{lllll}
\hline País exportador & Destino final & Chegada & Quantidade (t) & Porcentagem \\
\hline EUAN & BA & RJ & 44,4 & 0,5 \\
\hline & CE & CE & 0,4 & 0,004 \\
\hline & MG & MG & 6,2 & 0,07 \\
\hline & PR & SP & 3,4 & 0,04 \\
\hline & RJ & RJ, SP & 20,8 & 0,2 \\
\hline SP & SP, PR & $9.026,3$ & 99,2 \\
\hline Argentina & PR & PR & 17,1 & \\
\hline & RJ & RJ, RS & 5,1 & 5,9 \\
\hline & RS & RS & 54,0 & 1,8 \\
\hline & SP & RS, CE, PR, SP & 211,1 & 73,8 \\
\hline Espanha & SP & SP & 18,5 \\
\hline França & SP & SP & 100 \\
\hline
\end{tabular}

Fonte: Brasil (1996)

Tabela 8. Destino final de ameixas importados pelo Brasil de janeiro de1992 a agosto de 1996, por país exportador.

\begin{tabular}{lllll}
\hline País exportador & Destino final & Chegada & Quantidade (t) & Porcentagem \\
\hline EUAN & AM & AM & 5,9 & 0,012 \\
\hline & CE & CE & 1,2 & 0,002 \\
\hline PR & SP & 6,4 & 0,012 \\
\hline RS & SP & 0,6 & 0,001 \\
\hline & SC & SP & 1,4 & 0,003 \\
\hline SP & SP & $47.703,7$ & 99,9 \\
\hline Holanda & SP & SP & & \\
\hline & & & & 100 \\
\hline Portugal & SP & SP & 19,9 & 100 \\
\hline
\end{tabular}

Fonte: Brasil (1996) 
Tabela 9. Destino final de nectarinas importadas pelo Brasil de janeiro de1992 a agosto de 1996, por país exportador.

\begin{tabular}{lllll}
\hline País exportador & Destino final & Chegada & Quantidade (t) & Porcentagem \\
\hline EUAN & PR & SP & 6,4 & 0,1 \\
\hline RJ & RJ & 11,5 & 0,1 \\
\hline SC & SP & 0,5 & 0,004 \\
\hline SP & SP & $13.627,8$ & 99,9 \\
\hline
\end{tabular}

Fonte: Brasil (1996)

Tabela 10. Destino final de morangos importados pelo Brasil de janeiro de1992 a agosto de 1996, por país exportador.

\begin{tabular}{lllll}
\hline País exportador & Destino final & Chegada & Quantidade (t) & Porcentagem \\
\hline EUAN & CE & CE & 1,1 & 0,6 \\
\hline PE & PE & 2,4 & 1,3 \\
\hline SP & SP & 188,1 & 98,2 \\
\hline
\end{tabular}

Fonte: Brasil (1996) 
ANEXo E - CONDIÇões RECOMENDADAS PARA O TRANSPORTE DE FRUTAS FRESCAS

\begin{tabular}{lcc}
\hline Fruta & $\begin{array}{c}\text { Temperatura Ambiente no } \\
\text { container }\left({ }^{\circ} \mathbf{C}\right)\end{array}$ & Umidade Relativa (\%) \\
\hline Maçã - não sensível ao frio & $1,1-2,2$ & $90-95$ \\
\hline Maçã - sensível ao frio & 4,4 & $90-95$ \\
\hline Melão - cantalupe & $3,4-4,4$ & $85-90$ \\
\hline Melão - honeydew & $7,8-10,0$ & $85-90$ \\
\hline Morango & $1,1-2,2$ & $90-95$ \\
\hline Pêra & $0,6-1,7$ & $90-95$ \\
\hline Uva & $1,1-2,2$ & $90-95$ \\
\hline
\end{tabular}

Fonte: USDA citado por Brasil (1994) 


\section{REFERÊNCIAS BIBLIOGRÁFICAS}

ABDULlAEV, A. N.; MUGUTDINOV, N. S. [Brown mite in the orchards of the Dagestan foothills.] Sadovodstvo, n.11, p.24-25, 1976. /Resumo em CAB Abstracts on CD-ROM, 1976-78/

ACKERMAN, R. A.; HALTEREN, P. van; JENNISKENS, M. J. P. J. (Ed.) Annual report 1992: diagnostic centre. Wageningen: Plant Protection Service, 1994. p.105: Interceptions of plant parasitic insect and mite species. (Verslagen en Mededelingen, 170).

ACKerman, R. A.; HALteren, P. van; JENNISKENS, M. J. P. J. (Ed.) Annual report 1994: diagnostic centre. Wageningen: Plant Protection Service, 1995. p.3738 e 127: Interceptions of plant parasitic insect and mite species. (Verslagen en Mededelingen, 177).

AGUILERA, P. A. Nuevas localidades para Stethorus histrio Chazeau (Coleoptera: Coccinellidae) en Chile. Revista Chilena de Entomologia, v.15, p.33-36, 1987. /Resumo em CAB Abstracts on CD-ROM, 1987-89/

AHMED, Z. I.; AHMED, R. F. [The effect of prey (strawberry mite) densities Tetranychus turkestani Ugarov \& Nikolski (Acariformes: Tetranychidae) on the functional and numerical efficiency of Stethorus gilvifrons Mulsant (Coleoptera: Coccinellidae) in the laboratory.] Journal of Agriculture and Water Resources Research, Plant Production, v.7, n.1, p.111-122, 1988. /Resumo em CAB Abstracts on CD-ROM, 1987-89/ 
AHN, YOUNG JOON; YOO, JAI KI; CHO, JUM RAE; LEE, JEANG OON; MOON, SUNG CHUL Evaluation of effectiveness of AC 303630 and flucycloxuron mixtures against Tetranychus urticae (Acari: Tetranychidae) under laboratory and field conditions. Applied Entomology and Zoology, v.31, n.1, p.67-73, 1996. /Resumo em CAB Abstracts on CD-ROM, 1996-97/

AHUMADA, M. H.; MITCHAM, E. J.; MOORE, D. G. Postharvest quality of 'Thompson Seedless' grapes after insecticidal controlled-atmosphere treatments. HortScience, v.31, n.5, p.833-836, 1996.

AKIMOV, I. A.; VOITENKO, A. N.; POGREBNYAK, S. G. [The influence of pesticidal pressure, temperature and humidity on mite complexes in Ukrainian orchards.] Vestnik Zoologii, n.6, p.83-88, 1994. /Resumo em CAB Abstracts on CD-ROM, Jan.-Oct. 1996/

AL MALLAH, N. M.; ABDALLA, S. I. [On the biology of the strawberry mite Tetranychus turkestani Uga. \& Nik. (Tetranychidae, Acariformes) and the susceptibility of three gladiolus cultivars to infestation under greenhouse conditions.] Arab Journal of Plant Protection, v.8, n.1, p.21-24, 1990. /Resumo em CAB Abstracts on CD-ROM, 1990-91/

AL NE'AMI, K. T. [Side effects of insecticides on the strawberry spider mite, Tetranychus turkestani (Ugar. \& Nik.) (Acarina, Tetranychidae) and their natural enemies.] Anzeiger fur Schadlingskunde und Pflanzenschutz, v.54, n.11, p.161164, 1981. /Resumo em CAB Abstracts on CD-ROM, 1982-83/

ALFORD, D. V.; WOODVILL E., H. C.; YARHAM, D. J. Occurrence of bud rot of carnation in Hertfordshire. Plant Pathology, v.25, n.2, p.116-117, 1976. /Resumo em CAB Abstracts on CD-ROM, 1976-78/ 
ALI NIAZEE, M. T.; STAFFORD, E. M.; KIDO, H. Management of grape pests in central California vineyards: toxicity of some commonly used chemicals to Tetranychus pacificus and its predator, Metaseiulus occidentalis. Journal of Economic Entomology, v.67, n.4, p.543-547, 1974.

AMANO, H.; CHANT, D. A. Species diversity and seasonal dynamics of Acari on abandoned apple trees in southern Ontario, Canada. Experimental and Applied Acarology, v.8, p. 71-96, 1990.

AMRINE JR., J. W.; : STASNY, T. A. Catalog of the Eriophyoidea (Acarina: Prostigmata) of the World. West Bloomfield: Indira Publishing House, 1994. $795 p$.

ANDERSON, N. H.; MORGAN, C. V. G. Life-histories and habits of the clover mite, Bryobia praetiosa Koch, and the brown mite, B. arborea M. \& A.; in British Columbia (Acarina: Tetranychidae). The Canadian Entomologist, v. 90, n.1, p.23$42,1958$.

ANDREI, E. Compêndio de defensivos agrícolas. 5. ed. São Paulo: Organização Andrei Editora, 1996. 506p.

ANFINNIKOV, M. A. [Experience in orchard protection.] Zashchita Rastenii, n.9, p.27-28, 1979. /Resumo em CAB Abstracts on CD-ROM, 1979-81/

ANGELI, G.; IORIATTI, C.; FORTI, D.; MAINES, R. [Sensibility to clofentezine in four strains of Panonychus ulmi Koch (Piedmont, Trentino - Alto Adige).] Informatore Fitopatologico, v.44, n.11, p.38-41, 1994. /Resumo em AGRIS on CD-ROM, 1995-96/

ANGERILLI, N. P. D.; BROCHU, L. Some influences of area and pest management on apple mite populations in the Okanagan Valley of British Columbia. Journal of the Entomological Society of British Columbia, v.84, p.3-9, 1987. /Resumo em CAB Abstracts on CD-ROM, 1987-89/ 
ANTHON, E. W.; SMITH, L. O. Integrated control of mites on prunes in central Washington. Journal of Economic Entomology, v.68, n.5, p.655-656, 1975.

ANUÁRIO ESTATÍSTICO DO BRASIL - 1996, v.56, p. 3.30-3.55, 1997.

ARIAS GIRALDA, A.; BAILLOD, M.; CORINO, L.; KREITER, S.; LAURENT, J. C.; SCHRUFT, G.; VALENTIN, G.; VILA, Y. [The mite pests of grapevines.] Stapleford: Schering, 1988. 136p. /Resumo em CAB Abstracts on CD-ROM, 1990-91/

ARIAS GIRALDA, A.; NIETO CALDERON, J. Eficácia de dos insecticidas fosforados orgánicos y dos piretroides contra "polilla del rácimo" (Lobesia botrana Den. \& Schiff.) y efecto secundario sobre "araña amarilla comun" (Tetranychus urticae Koch). Boletin del Servicio de Defensa contra Plagas e Inspección Fitopatológica, v.7, n.1-2, p.185-197, 1982. /Resumo em CAB Abstracts on CDROM, 1982-83/

ARIAS GIRALDA, A; NIETO CALDERON, J. El "ácaro de la roña" (Brevipalpus lewisi McGregor), nuevo parásito de la vid en España: invernación, colonización de las cepas y prospección en la comarca de Guarena (Badajoz). Boletin del Servicio de Defensa contra Plagas e Inspección Fitopatológica, v.11, n.2, p. 193-203, 1985. /Resumo em CAB Abstracts on CD-ROM, 1984-86/

ASAKAWA, N. M.; RAMIREZ, R. CA Inoculation and planting methodology for Arachis pintoi. Pasturas Tropicales, v.11, n.1, p.24-26, 1989.

ASHIHARA, W. [Studies on the occurrence of the Kanzawa spider mite, Tetranychis kanzawai Kishida (Acarina: Tetranychidae) and its biological control by Phytoseiulus persimilis Athias-Henriot (Acarina: Phytoseiidae) on grapevine in greenhouses.] Bulletin of the Fruit Tree Research Station, Extra, n.6, p.75-151, 1995. /Resumo em CAB Abstracts on CD-ROM, 1996-97/

ATANASOV, N. [Mites on fruit crops.] Rastitelna Zashchita, v.31, n.8, p.7-9, 1983. /Resumo em CAB Abstracts on CD-ROM, 1984-86/ 
ATANASOV, N. [Studies of the distribution, food-plants and injuriousness of the Atlantic mite (Tetranychus atlanticus McGregor).] Rasteniev"dni Nauki, v.7, n.6, p.107-114, 1970. /Resumo em CAB Abstracts on CD-ROM, 1972-75/

ATANASOV, N. [The Atlantic mite (Tetranychus atlanticus McGregor) - a pest of groundnut.] Rasteniev"dni Nauki, v.8, n.7, p.149-155, 1971. /Resumo em CAB Abstracts on CD-ROM, 1972-75/

ATANASOV, N.; MITKOV, A.; SLAVOV, D. [Biological control of spider mites on pepper in the greenhouse.] Rastitelna Zashchita, v.31, n.10, p.29-31, 1983. /Resumo em CAB Abstracts on CD-ROM, 1984-86/

AVEYARD, C. S. Recent developments with amitraz for mite control on top fruit. In: BRIGHTON CROP PROTECTION CONFERENCE, PESTS AND DISEASES, Brighton, 1988. Proceedings. Thornton Heath: British Crop Protection Council, 1988, v. 1, p.211-216. /Resumo em CAB Abstracts on CD-ROM, 1990-91/

BADOWSKA-CZUBIK, T.; PALA, E. [The apple leaf mite (Aculus schlechtendali) - a pest of apple.] Ochrona-Roslin, v.37, n.10, p.12-13, 1993. /Resumo em CAB Abstracts on CD-ROM, Jan.-Mar. 1996/

BAGGIO, D.; FIGUEIREDO, S. M.; FLECHTMANN, C. H. W.; ZAMBON, G. Q; MIRANDA, S. H. G. Avaliação da presença de ácaros em cereais armazenados na grande São Paulo. Anais da Escola Superior de Agricultura "Luiz de Queiroz", v.44, p.617-626, 1987.

BAILEY, P.; SWINCER, D.; STONE, C.; EDGE, V. E. Chemical alternatives for controlling twospotted mite (Tetranychus urticae Koch) with resistance to cyhexatin. In: AUSTRALIAN APPLIED ENTOMOLOGICAL RESEARCH CONFERENCE, 4., Adelaide, 1984. Pest control: recent advances and future prospects; proceedings. Adelaide: Australia: South Australian Government Printer, 1984. p.281-285. /Resumo em CAB Abstracts on CD-ROM, 1984-86/ 
BAILLOD, M. ANTONIN P.; GUIGNARD, E.; DUVERNEY, C.; ZAHNER, P.; KLAY, A.; GENINI, M. [Problems of controlling phytophagous mites (P. ulmi and T. urticae) in apple orchards.] Revue Suisse de Viticulture, d'Arboriculture et d'Horticulture, v.14, n.2, p.113-121, 1982a. /Resumo em CAB Abstracts on CDROM, 1982-83/

BAILLOD, M.; ANTONIN, P.; MITTAZ, C. [Migrations, population estimates and injuriousness of the common yelow spider-mite, Tetranychus urticae Koch in viticulture in Wallis.] Revue Suisse de Viticulture, d'Arboriculture et d'Horticulture, v.21, n.3, p.179-183, 1989. /Resumo em CAB Abstracts on CDROM, 1990-91/

BAILLOD, M.; SCHMID, A.; GUIGNARD, E; ANTONIN, P.; CACCIA, R. [Biological control of the red spider mite in viticulture. II. Natural equilibria, population dynamics and experiences with the release of Typhlodromus.] Revue Suisse de Viticulture, d'Arboriculture et d'Horticulture, v.14, n.6, p.345-352, 1982b. /Resumo em CAB Abstracts on CD-ROM, 1982 -83/

BAKER, E. W.; PRITCHARD, A. E. The Tetranychoid mites of Africa. Hilgardia, v.29, n.11, p.455-574, 1960.

BAKER, E. W; TUTTLE, D. M. A new species of Tetranychus (Acarina: Tetranychidae) intercepted at quarantine from cacao. International Journal of Acarology, v.2, n.1, p.13-16, 1976.

BAKER, E. W.; TUTTLE, D. M. A new species of Petrobia (Acari: Tetranychidae) from Mexico collected in quarantine at El Paso, Texas. International Journal of Acarology, v.9, n.3, p.157-159, 1983.

BAKER, E. W.; TUTTLE, D. M. The false spider mites of Mexico (Tenuipalpidae: Acari). Springfield: USDA, 1987. 237p. (Technical Bulletin, 1706)

BAKER, E. W.; TUTTLE, D. M. A guide to the spider mites (Tetranychidae) of the United States. West Bloomfield: Indira Publishing House, 1994. 347p. 
BAKER, R. H. A. The potential for geographical information systems in analysing the risks posed by exotic pests. In: BRIGHTON CROP PROTECTION CONFERENCE, PESTS AND DISEASES, Brighton, 1994. Proceedings. Nottingham: Major Print, 1994, v.1, p.211-216.

BAKER, R. T.; COWLEY, J. M.; HARTE, D. S. Pest risk assessment: a process for the assessment of pest risk associated with the importation of plants and plant products into New Zealand. Auckland: Lynfield Plant Protection Centre, 1993. 12p. (Publications, 1).

BAKER, R.; COWLEY, J. M Evaluation of the economic impact of newly introduced pests. New Zealand Journal of Forestry Science, v.19, n.2-3, p.330-334, 1989.

BALEVSKI, A. [How we control the second generation of the codling moth and the yellow apple mite on vines.] Rastitelna Zashchita, v.28, n.6, p.42-43, 1980. /Resumo em CAB Abstracts on CD-ROM, 1979-81/

BALEVSKI, A.; GANOVA LAZAROVA, P. [Mites of greenhouse flower crops and their control.] Gradinarstvo, v.15, n.9, p.29-32, 1973. /Resumo em CAB Abstracts on CD-ROM, 1972-75/

BALS, N. [An example of practical application of integrated control in vineyards in l'Herault in 1994.] Progrès Agricole et Viticole, v.112, n.15-16, p.334-337, 1995. /Resumo em CAB Abstracts on CD-ROM, Jan.-Oct. 1996/

BARNES, B. N. Irradiation-disinfestation of export fruit as a quarantine treatment for proclaimed insects: the potentialities and problems. In: CONGRESS OF THE ENTOMOLOGICAL SOCIETY OF SOUTHERN AFRICA, 1., 1974. Proceedings. Stellenbosch: Entomological Society of Southern Africa, 1975. p.163-171.

BARNES, M. M.; MADSEN, H. F. Insect and mite pests of apple in California. Berkeley: California Agricultural Experiment Station Extension Service, 1961, 30p. (Circular, 502) 
BASSINO, J. P.; FORT, G.; GENDRIER, J. P.; REBOULET, J. N. [Integrated control in pear orchards. First results obtained in France. A pest that is difficult to master: the common psylla.] In: SYMPOSIUM ON INTEGRATED CONTROL IN ORCHARDS, 5., Bolzano, 1974. Proceedings. Wageningen: Organisation Internationale de Lutte Biologique contre les Animaux et les Plantes Nuisibles, 1975. p. 153-174. /Resumo em CAB Abstracts on CD-ROM, 1976-78/

BAYAN, A. [Biological studies on Cenopalpus pulcher Can. \& Fanz. (TenuipalpidaeAcari), as a pest on apples in Lebanon.] Arab Journal of Plant Protection, v.2, n. 1, p.28-31, 1984. /Resumo em CAB Abstracts on CD-ROM, 1984-86/

BAYAN, A. [Mites on plums in Lebanon. II. Fluctuations of their population density and abundance on plum trees in Baalbeck (Bekaa).] Arab Journal of Plant Protection, v.7, n.1, p.30-36, 1989. /Resumo em CAB Abstracts on CD-ROM, 1990-91/

BAYATASSADI, H.; PARSI, B. [Some studies on the European red mite Panonychus ulmi (Koch) in the region of Gorgan.] Entomologie et Phytopathologie Appliquées, v.48, n.1, p.67-73, 1980. /Resumo em CAB Abstracts on CD-ROM, 1979-81/

BEERS, E. H.; HULL, L. A. Effect of European red mite (Acari: Tetranychidae) injury on vegetative growth and flowering of four cultivars os apples. Environmental Entomology, v.16, n.2, p.569-574, 1987.

BEERS, E. H.; HULL, L. A. Timing of mite injury affects the bloom and fruit development of apple. Journal of Economic Entomology, v.83, n.2, p.547-551, 1990.

BENAVIDES L., A. L. Efecto de la cera y film de cloruro de polivinilo (P. V. C.) sobre el control de la falsa arañita roja de la vid Brevipalpus chilensis Baker al estado de huevo y conservación de frutos de chirimoya (Annona cherimola Mill.) cv. Concha lisa. Quillota, 1991. 127p. Tesis (Ing. Agr.) - Facultad de Agronomia, Universidad Catolica de Valparaiso. /Resumo em AGRIS on CD-ROM, 1991-92/ 
BLAISE, T.; LOUVET, J. M. [A biological control trial against a phytophagous mite. The use of Typhlodromus pyri against Tetranychus mcdanieli in Champagne.] Phytoma, n.436, p.42-44, 1992. /Resumo em CAB Abstracts on CD-ROM, 1993 $-941$

BLANC, M. [Tetranychus turkestani in soybean. Development of the pest in the SouthEastern France, its control.] Defence des Vegetaux, v.42, n.249/250, p.19-20, 1988. /Resumo em AGRIS on CD-Rom, 1989-90/

BLEICHER, E. Ocorrência do ácaro Panonychus ulmi (Koch, 1836) Tuttle \& Baker (1966) no estado de Santa Catarina. O Solo, v.66, n.1, p.64, 1974.

BODINGIUS, P. [Apple rust mite an increasing problem.] Fruitteelt Den Haag, v.80, n.8, p.26-27, 1990. /Resumo em CAB Abstracts on CD-ROM, 1990-91/

BOL'SHAKOVA, V. N.; LITVINOV, P. I. [Characteristics of the development of Tetranychus telarius in the vineyard.] Zashchita Rastenii Moskva, n.7, p.40-42, 1991. /Resumo em CAB Abstracts on CD-ROM, 1993-94/

BOL'SHAKOVA, V. N.; LITVINOV, P. I. [New acaricides in vineyards.] Zashchita Rastenii Moskva, n.5, p.11, 1994. /Resumo em CAB Abstracts on CD-ROM, Jan.-Oct., 1995/

BOLLER, E. [Important time for pest monitoring and predatory mites.] Schweizerische Zeitschrift fur Obst und Weinbau, v.124, n.10, p.285, 1988. /Resumo em CAB Abstracts on CD-ROM, 1987-89/

BONATO, O.; COTTON, D.; KREITER, S.; GUTIERREZ, J. Influence of temperature on the life-history parameters of the yellow grape-vine mite Eotetranychus carpini (Oudemans) (Acari: Tetranychidae). International Journal of Acarology, v.16, n.4, p.241-245, 1990. 
BOND, E. J.; HERNE, D. H. C.; DUMAS, T. Control of overwintering stages of mites on apples using ethylene dibromide. The Canadian Entomologist, v.105, n.6, p.903-908, 1973.

BOSTANIAN, N. J.; PARADIS, R. O.; PITRE, D. Susceptibility of phytophagous mites to a single summer treatment of acaricides in a Quebec apple orchard. Phytoprotection, v.62, n.1, p.33-38, 1981. /Resumo em CAB Abstracts on CDROM, 1982-83/.

BOWMAN, C. E.; BARLETT, P. W. Panonychus citri (McGregor) (Acari: Tetranychidae) infesting imported Citrus mitis in England. Plant Pathology, v.27, n.4, p.201, 1978.

BOZAI, J. [Protection against spider mites damaging grapevines.] Kerteszet es Szoleszet, v.25, n.24, p.6, 1976. /Resumo em CAB Abstracts on CD-ROM, 1976$78 /$

BOZAI, J. [Study of faunistics and population dynamics phytophagous and predatory mites in Hungarian apple orchards (Panonychus ulmi, Tetranychus viennensis, Tetranychus telarius, Brevipalpus pulcher, Amblyseius finlandicus, Phytoseius plumifer, Amblyseius aberrans).] Novenyvedelem, v.20, n.6, p.253, 1986. /Resumo em AGRIS on CD-ROM, 1986-88/

BRASIL. Ministério da Agricultura e Reforma Agrária, Departamento Nacional de Meteorologia Normais climatológicas (1961-1990). Brasília, 1992. 84p.

BRASIL. Ministério da Agricultura e Reforma Agrária, Programa de Apoio à Produção e Exportação Frutícola. Manual de exportação de frutas. Brasília: FRUPEX, 1994. 254p.

- BRASIL. Ministério da Agricultura, do Abastecimento e da Reforma Agrária Diário Oficial, n. 195, out. 1995. 112p. Suplemento. 
BRASIL. Ministério da Agricultura, do Abastecimento e da Reforma Agrária Sistema de controle de importação e exportação. Brasília: Secretaria Nacional de Defesa Agropecuária, 1996.

BRITO, R. M.; STERN, V. M.; SANCES, F. V. Physiological response of cotton plants to feeding of three Tetranychus spider mite species (Acari: Tetranychidae). Journal of Economic Entomology, v.79, n.5, p.1217-1220, 1986.

BRUN, L. O.; EDGE, V. E.; GUTIERREZ, J. The occurrence of five Tetranychus spp. (Acari: Tetranychidae) in New Caledonia and their responses to acaricides. Tropical Pest Management, v.29, n.4, p.371-377, 1983. /Resumo em CAB Abstracts on CD-ROM, 1984-86/

BUChanAN, G. A.; BengSTON, M.; EXLEY, E. M. Population growth of Brevipalpus lewisi McGregor (Acarina: Tenuipalpidae) on grapevines. Australian Journal of Agricultural Research, v.31, n.5 p.957-965, 1980. /Resumo em CAB Abstracts on CD-ROM, 1979-81/

BULGAK, V. D. [Harmfulness of spider mites on apple in the Crimea.] In: NOVOZHILOV, R. V. (Ed.) Injuriousness of insect pests and diseases of agricultural crops. Leningrad: All Union Lenin Academy of Agricultural Sciences, 1979. p.80-86. /Resumo em CAB Abstracts on CD-ROM, 1982-83/

BULUT, H.; OKUL, A.; ATAC, O. [Chemical tests against hawthorn mite (Tetramychus viennensis Zacher) harmful on apple trees in central Anatolia.] Zirai Mucadele Arastirma Yilligi, n.22-23, p.9-10, 1992a. /Resumo em CAB Abstracts on CDROM, Jan.-Oct. 1995/

BULUT, H.; OKUL, A.; CEVIK, T. [Chemical test against codling moth (Cydia pomonella L.) in central Anatolia.] Zirai Mucadele Arastirma Yilligi, n.22-23, p.19-20, 1992b. /Resumo em CAB Abstracts on CD-ROM, Jan.-Oct. 1995/ 
BULUT, H.; ZEKI, C. [Investigations on the effectiveness of some pesticides, used in the control of codling moth (Cydia pomonella L.) (Lepidoptera: Tortricidae), on the population of Tetranychus viennensis Zacher (Acarina, Tetranychidae).] In: TURKISH NATIONAL CONGRESS OF ENTOMOLOGY, 2., 1992. Proceedings. Izmir: Ege Universitesi, 1992. p. 343-353 /Resumo em CAB Abstracts on CDROM, 1993-94/

BYRNE, D. H.; BELLOTTI, A. C.; GUERRERO, J. M. The cassava mites. Tropical Pest Management, v.29, n.4, p.378-394, 1983.

CAGLE, L. R. Life history of the spider mite Tetranychus schoenei McG. Virginia: Agricultural Experiment Station, 1943. 16p. (Technical Bulletin, 87)

CAI, N. H.; QIN, Y. C.; HU, D. X. [Evaluations of the damage of two spider mite species to apple tree.] Acta Phytophylactica Sinica, v.19, n.2, p.165-170, 1992. /Resumo em CAB Abstracts on CD-ROM, 1993-94/

CAMERON, P. J.; WEARING, C. H.; KAIN, W. M.; HOY, M. A. Genetic improvement of Metaseiulus occidentalis: implementing pesticide resistant strains progress and problems. In: AUSTRALASIAN WORKSHOP ON DEVELOPMENT AND IMPLEMENTATION OF IPM, 1982. Proceedings. Auckland: Govt. Print, 1982. p.18-28. /Resumo em CAB Abstracts on CD-ROM, 1982-83/

CANNERDAY, T. D.; ARANT, F. S. The effect of spider mite populations on yield and quality of cotton. Journal of Economic Entomology, v.57, p.553-556, 1964.

CAO, Z. G.; ZHANG, Y. H.; LIU, W.; WANG, Z. L. [Study on insecticide resistance of Tetranychus viennensis (Zacker) and Panonychus ulmi (Koch).] Insect Knowledge, v.27, n.6, p.346-349, 1990. /Resumo em CAB Abstracts on CD-ROM, 1990-91/

CARDOZO, C. I.; FERGUSON, J. E. Producción de semilla de Arachis pintoi cv. maní forrajero perene asociado con cultivos de maíz y frijol. Pasturas Tropicales, v.17, n.3, p.32-36, 1995. 
CAREY, J. R.; BRADLEY, J. W. Developmental rates, vital schedules, sex ratios and life tables for Tetranychus urticae, T. turkestani and T. pacificus (Acarina: Tetranychidae) on cotton. Acarologia, v.23, n.4, p.333-345, 1982.

CARLSON, E. C. Spider mites on soybeans - injury and control. California Agriculture, v.23, n.5, p.16-18, 1969.

CARLSON, E. C.; BEARD, B. H.; TARAILO, R.; WITT, R. L. Testing soybeans for resistance to spider mites. California Agriculture, v.33, n.9, p.9-11, 1970.

CASTAGNOLI, M.; AMATO, F.; MONAGHEDDU, M. [Biological observations and demographic parameters of Eotetranychus carpini (Oud.) (Acarina: Tetranychidae) and its predator Typhlodromus exhilaratus Ragusa (Acarina: Phytoseiidae) under laboratory conditions.] Redia, v.72, n.2, p.545-557, 1989. /Resumo em CAB Abstracts on CD-ROM, 1990-91/

CHAK"ROV, K. [Studies of the winter eggs of fruit-tree mites in the Kamchiiski fruitgrowing area.] Rastitelna Zashchita, v.18, n.5, p.23-25, 1970. /Resumo em CAB Abstracts on CD-ROM, 1972-75/

CHAK"ROV, K. [Control measures against pests of grape vine.] Rastitelna Zashchita, v.21, n. 12, p.12-14, 1973. /Resumo em CAB Abstracts on CD-ROM, 1976-78/

CHAPMAN, R. B.; PENMAN, D. R. Negatively correlated cross-resistance to a synthetic pyrethroid in organophosphorus-resistant Tetranychus urticae. Nature, v.281, n.5729, p.198-299, 1979. /Resumo em CAB Abstracts on CD-ROM, 1979$81 /$

CHAPMAN, R. B.; PENMAN, D. R. Resistance to propargite by European red mite and two-spotted mite. New Zealand Journal of Agricultural Research, v.27, n.1, p.103-105, 1984. /Resumo em CAB Abstracts on CD-ROM, 1984-86/ 
CHAPMAN, R. B.; PENMAN, D. R.; WALKER, J. T. S. European red mite resistance to organotin miticides in Hawke's Bay apple orchards. In: NEW ZEALAND WEED AND PEST CONTROL CONFERENCE, 1987. Proceedings. Palmerston North: New Zealand Weed and Pest Control Society, 1987. p.94-98. /Resumo em CAB Abstracts on CD-ROM, 1987-89/

CHAZEAU, J. Predaceous Insects. In: HELLE, W.; SABELIS, M. W. (Ed.) Spider mites: their biology, natural enemies and control. Amsterdan: Elsevier, 1985. v.1B, cap. 2.3., p.211-246.

CHEPUMAYA, V. I.; MYALOVA, L. A. [Pests and diseases of cherry.] Zashchita Rastenii, n.7, p.53-55, 1981. /Resumo em CAB Abstracts on CD-ROM, 1982-83/

CHIAVEGATO, L. G.; MISCHAN, M. M.; COTAS, M. P. Resistência do ácaro rajado Tetranychus (T.) urticae (Koch, 1836) (Acari, Tetranychidae) proveniente de diferentes regiões algodoeiras aos acaricidas. Cientifica, v.11, n.1, p.57-62, 1983.

CHICHIGNOUD, C.; MARTIN, N. [Pyridabene. Apple and vine acaricide.] Phytoma, n.432, p.60-62, 1991. /Resumo em CAB Abstracts on CD-ROM, 1993-94/

CHMIELEWSKI, W. [The results of studies on the mite fauna in imported goods, with particular reference to the species new for Poland.] Prace Naukowe Instytutu Ochrony Roslin, v.13, n.2, p.187-200, 1972. Resumo em CAB-Abstracts on CDROM, 1972-75/.

CHO, JUM RAE; KIM, YOUNG JOON; AHN, YOUNG JOON; YOO, JAIKI; LEE, JEONG OON [Monitoring of acaricide resistance in field-collected populations of Tetranychus urticae (Acari: Tetranychidae) in Korea.] Korean Journal of Applied Entomology, v.34, n.1, p.40-45, 1995. /Resumo em CAB Abstracts on CD-ROM, Jan.-Oct 1995/

CHUBINNISHVILI, T. I.; KOBLIANIDZE, Y. V.; PETRUSHOV, A. Z.; ZIL'BERMINTS, I. V. [Introduction of resistant Metaseiulus.] Zashchita Rastenii, n. 1, p.30-31, 1982. /Resumo em CAB Abstracts on CD-ROM, 1982-83/ 
CIAMPOLINI, M.; ROTA, P. A.; SCHULTHAUS, S. [Apple rust caused by the eriophyid Aculus schlechtendali.] Informatore Agrario, v.32, n.40, p.2424324245, 1976. /Resumo em CAB Abstracts on CD-ROM, 1976-78/

COLARICCIO, A.; LOVISOLO, O.; CHAGAS, C. M.; GALLETI, S. R.; ROSSETTI, V.; KITAJIMA, E. M. Transmissão mecânica e aspectos ultraestruturais da leprose dos citros. Fitopatologia Brasileira, v.20, n.2, p.208-213, 1995.

COOK, B. G.; WILLIAMS, R. J.; WILSON, G. P. M. Arachis pintoi Krap. et Greg. nom. nud. (pinto peanut) cv. Amarillo. Australian Journal of Experimental Agriculture, v.30, n.3, p.445-446, 1990. /Resumo em CAB-Abstracts on CDROM, 1990-91/

CORNEL, A. J.; HARTWIG, E. K. Importation of used tyre casings: a possible health hazard. South African Journal of Sciences, v.85, n.8, p.487-488, 1989.

COSTA-COMELLES, J.; DEL RIVERO, J. M.; FERRAGUT, F.; GARCIA-MARI, F. Control integrado de ácaros en manzano en España. Investigación Agraria, n.2, p.49-63, dic. 1994.

COUILLAUD, R.; AUBERTIN, F. [Influence of insecticide protection on the technological characteristics of cotton fibre in Iran.] Coton et Fibres Tropicales, v.25, n.4, p.489-494, 1970. /Resumo em CAB Abstracts on CD-ROM, 1972-75/

CRANHAM, J. E. Resistance to organophosphates in red spider mite, Tetranychus urticae, from English hop gardens. Annals of Applied Biology, v.78, n.2, p.99-111, 1974.

CRANHAM, J. E. Resistance to binapacryl in field populations of fruit tree red spider mite, Panonychus ulmi (Koch). Plant Pathology, v.24, p.39-44, 1975.

CRANHAM, J. E. Resistance to organophosphates, and the genetic background, in fruit tree red spider mite, Panonychus ulmi, from English apple orchards. Annals of Applied Biology, v.100, p.11- 23, 1982a. 
CRANHAM, J. E. Resistance to binapacryl and tetradifon, and the genetic background, in fruit tree red spider mite, Panonychus ulmi, from English apple orchards. Annals of Applied Biology, v. 100, p.25-38, $1982 \mathrm{~b}$.

CRANHAM, J. E. Hop. In: HELlE, W.; SABELIS, M. W. (Ed.) Spider mites: their biology, natural enemies and control. Amsterdan: Elsevier, 1985. v.1, cap.3.2.10, p.367-370.

CRANHAM, J. E.; HELLE, W. Pesticide resistance in Tetranychidae. In: HELLE, W; SABELIS, M. W. (Ed.) Spider mites: their biology, natural enemies and control. Amsterdan: Elsevier, 1985. cap.3.4, p.405-421.

CROFT, B. A. Integrated control of apple mites. East Lansing: Michigan State University, Cooperative Extension Service, 1975. 12p. (Extension Bulletin, E-825)

CROFT, B. A.; JORGENSEN, C. D. Typhlodromus mcgregori Chant (Acarina: Phytoseiidae) and its control of phytophagous mites in Utah and southern California apple orchards. Great Basin Naturalist, v.37, n.3, p.366-374, 1977. /Resumo em CAB Abstracts on CD-ROM, 1979-81/

CROFT, B. A.; MAC RAE, I. V. Persistence of Typhlodromus pyri and Metaseiulus occidentalis (Acari: Phytoseiidae) on apple after inoculative release and competition with Zetzellia mali (Acari: Stigmaeidae). Environmental Entomology, v.21, n.5, p.1168-1177, 1992.

CURKOVIC S., TOMISLAV; BARRIA P., GERARDO; GONZALEZ R., ROBERTO Evaluación de acaricidas en el control de las arañitas, Panonychus ulmi (Koch) y Brevipalpus chilensis Baker, y degradación de residuos de chinometionate y pyridaben. Revista Fruticola, v.15, n.3, p.105-114, 1994.

CURTIS, C. E.; CLARK, J. D.; TEBBETS, J. S.; MACKEY, B. E. Incidence of arthropods found in packed nectarine fruit in central California. Southwestern Entomologist, v.17, n.1, p.29-39, 1992. 
DANESHVAR, H. [A study on the fauna of plant mites in Azerbaidzhan.] Entomologie et Phytopathologie Appliquées, v.46, n.1/2, p.117-128, 1978. /Resumo em CAB Abstracts on CD-ROM, 1979-81/

DARAKCHIEVA, L. [Resistance of spider mite to some acaricides.] Rastitelna Zashchita, v.32, n.11, p.34-36, 1984. /Resumo em CAB Abstracts on CD-ROM, 1984-86/

DE LA CRUZ, R.; SUAREZ, S.; FERGUSON, J. E. The contribution of Arachis pintoi as a ground cover in some farming systems of Tropical America. In: KERRIDGE, P. C.; HARDY, B. (Ed.) Biology and agronomy of forage Arachis. Cali:CIAT, 1994. p.102-108. (CIAT publication, 240). /Resumo em AGRIS on CD-ROM, 1993-94/

DE MILLO, A. P. [Ecological-biological characteristics of the harmfulness of spider mites on cotton in Tajikstan.] In: NOVOZHILOV, K. V. (Ed.) Injuriousness of insect pests and diseases of agricultural crops. Leningrad: All Union Lenin Academy of Agricultural Sciences, 1979. p.55-65. /Resumo em CAB Abstracts on CD-ROM, 1982-83/

DELLEI, A.; SZENDREY, L. [Recent data on the mite fauna in vineyards in county Heves.] Novenyvedelem, v.27, n.3, p.124-128, 1991. /Resumo em AGRIS on CDROM, 1991-92/

DENMARK, H. A. Aculus pelekassi Keifer, another citrus mite in Florida. Proceedings of the Florida State Horticultural Society, v.75, p.25-27, 1962.

DENMARK, H. A.; MUMA, M. H. Phytoseiid mites of Brazil (Acari: Phytoseiidae). Revista Brasileira de Biologia, v.33, p.235-276, 1973.

DENNEHY, T. J.; GRANETT, J. Improved detection of dicofol-resistant spider mites in cotton. California Agriculture, v.36, n.11/12, p.11-12, 1982. 
DENNEHY, T. J.; GRANETT, J. Spider mite resistance to dicofol in San Joaquin Valey cotton: inter and intraspecific variability in susceptibility of three species of Tetranychus (Acari: Tetranychidae). Journal of Economic Entomology, v.77, n.6, p.1381-1385, 1984.

DENNEHY, T. J.; GRANETT, J.; LEIGH, T. F.; COLVIN, A. Laboratory and field investigations of spider mite (Acari: Tetranychidae) resistance to the selective acaricide propargite. Journal of Economic Entomology, v.80, n.3, p.565-574, 1987.

DENNEHY, T. J.; NYROP, J. P.; MARTINSON, T. E. Characterization and exploitation of instability of spider mite resistance to acaricides. In: GREEN, M. B.; LE BARON, H. M.; MOBERG, W. K. (Ed.) Managing resistance to agrochemicals: from fundamental research to practical strategies. Washington: American Chemical Society, 1990. cap.5, p.77-91.

DENNEHY, T. J.; NYROP, J. P.; REISSIG, W. H.; WEIRES, R. W. Characterization of resistance to dicofol in spider mites (Acari: Tetranychidae) from New York apple orchards. Journal of Economic Entomology, v.81, n.6, p.1551-1561, 1988.

DIBBLE, J. E. Insect pest management on curcubits. In: DESERT VEGETABLE INSECT SYMPOSIUM, 1., Berkeley, 1978. Berkeley: University of California/ Cooperative Extension, 1979. B14-B19. /Resumo em CAB Abstracts on CDROM, 1979-81/

DIECKMANN, M.; FRISON, E. A.; PUTTER, T. (Ed.) FAO/IPGRI technical guidelines for the safe movement of small fruit germplasm. Rome: FAO, 1994. $2 v$.

DITTRICH, V.; LUETKEMEIER, N.; VOSS, G. Dominant and recessive inheritance of organophosphorous resistance in two strains of Tetranychus urticae. Recent Advances in Acarology, v.1, p.401-404, 1979. /Resumo em CAB Abstracts on CD-ROM, 1979-81/ 
DOMINGUEZ VALENZUELA, J. A.; MARBÁN MENDOZA, N.; DE LA CRUZ, R. Leguminosas de cobertura asociadas con tomate var. "Dina guayabo" y su efecto sobre Meloidogyne arabicida López y Salazar. Turrialba, v.40, n.2, p.217-221, 1990.

DONG, H. F. [Control effect of the enhanced Liuyangmycin on leaf spider mites and its influence on the beneficial phytoseiid predators.] Chinese Journal of Biological Control, v.6, n.3, p.97-101, 1990. /Resumo em CAB Abstracts on CD-ROM, 1990-91/

DORESTE, E. Acarología. 2 ed. San José: IICA, 1988. 410p.

DUSO, C.; LIGUORI, M. [Research on grapevine mites in the Veneto: faunistic aspects and impact of pesticide treatments on the populations of phytophagous and predacious mites.] Redia, v.47, p.337-353, 1984. /Resumo em CAB Abstracts on CD-ROM, 1984-86/

DUSO, C.; TORRESAN, L.; VETTORAZZO, E. [Wild plants as a source of natural enemies: considerations on the occurrence of phytoseiid mites (Acari: Phytoseiidae) in a vineyard and nearby hedge.] Bollettino di Zoologia agraria e di Bachicoltura, v.25, n.2, p.183-203, 1993. /Resumo em CAB Abstracts on CD-ROM, Jan.-Oct. $1995 /$

EASTERBROOK, M. A. The life-history of the eriophyid mite Aculus schlechtendali on apple in South-east England. Annals of Applied Biology, v.91, p. 287-296, 1979.

EASTERBROOK, M. A. Chemical and integrated control of apple rust mite. In: BRITISH CROP PROTECTION CONFERENCE, PESTS AND DISEASES, Brighton, 1984. Proceedings. Croydon: British Crop Protection Council, 1984a. v.3, p.1107-1111 /Resumo em CAB Abstracts on CD-ROM, 1984-86/ 
EASTERBROOK, M. A. The biology and control of the rust mites Aculus schlechtendali and Epitrimerus piri on apple and pear in England. In: GRIFFITHS, D. A.; BOWMAN, C. E. (Ed.). Acarology VI. West Sussex: Ellis Horwood, 1984b. v.2, p.797-803.

EASTERBROOK, M. A. The effects of apple rust mite, Aculus schlechtendali, on the apple tree and its fruit. In: DUSBÁBEK, F.; BUKVA, V. (Ed.) Modern acarology, Prague: Academia; The Hague: SPB Academic Publ., 1991. v.1, p.601-606.

EASTERBROOK, M. A;; FULLER, M. M. Russeting of apples caused by apple rust mite Aculus schlechtendali (Acarina: Eriophyidae). Annals of Applied Biology, v. 109, p.1-9, 1986.

EASTERBROOK, M. A.; PALMER, J. W. The relationship between early-season leaf feeding by apple rust mite, Aculus schlechtendali (Nal.), and fruit set and photosynthesis of apple. Journal of Horticultural Science, v.71, n.6, p.939-44, 1996.

EASTERBROOK, M. A.; SOLOMON, M. G.; CRANHAM, J. E.; SOUTER, E. F. Trials of an integrated pest management programme based on selective pesticides in English apple orchards. Crop Protection, v.4, n.2, p.215-230, 1985. /Resumo em CAB Abstracts on CD-ROM, 1984-86/

EDGE, V. E.; JAMES, D. G. Organo-tin resistance in two-spotted mite, Tetranychus urticae Koch (Acarina: Tetranychidae) in Australia. In: INTERNATIONAL CONGRESS OF PLANT PROTECTION, 10., Brighton, 1983. Proceedings. Croydon: British Crop Protection Council, 1983. v.2, p.639. /Resumo em CAB Abstracts on CD-ROM, 1984-86/

EDGE, V. E.; JAMES, D. G. Organo-tin resistance in Tetranychus urticae (Acari: Tetranychidae) in Australia. Journal of Economic Entomology, v.79, n.6, p.14771483, 1986. 
EGGER, E. [Flexibility of defence strategies.] Informatore-Agrario, v.52, n.14, p.4565, 1996. /Resumo em CAB Abstracts on CD-ROM, Jan.-Oct. 1996/

EL DIN, M. H. T. Development of resistance to organophosphates and carbamates in Tetranychus urticae Koch in fruit orchards in Egypt. Acta Phytopathologica et Entomologica Hungarica, v.27, n.1/4, p.605-608, 1992. /Resumo em CAB Abstracts on CD-ROM, 1993-94/

EL HALAWANY, M. E.; ABOU EL ELA R. G.; ESMAIL, H. M.; EL ELA, R.G. A. Population dynamics of mites and their natural enemies on apple and apricot trees. Agricultural Research Review, v.68, n.1, p.59-66, 1990. /Resumo em CAB Abstracts on CD-ROM, 1992/

EL KADY, M. H.; SAID NASSAR, M. EL; HEYKAL, I. H.; NASSAR, M. EL, S. Effect of certain acaricides on the mite Cenopalpus pulcher on apple trees (Acarina, Tenuipalpidae). Agricultural Research Review, v.55, n.1, p.87-89, 1977. /Resumo em CAB Abstracts on CD-ROM, 1979-81/

ELMOSA, H. M. Studies on the biology of Cenopalpus pulcher (C. and F.) (Acarina, Tenuipalpidae) in Baghdad. Zeitschrift fur Angewandte Entomologie, v.67, n.4, p.394-396, 1971. /Resumo em CAB Abstracts on CD-ROM, 1972-75/

ENGLERT, W. D. [Aspects of integrated plant protection in viticulture.] Mitteilungen der Deutschen Gesellschaft fur Allgemeine und Angewandte Entomologie, v.4, n.1-3, p.171-172, 1983. /Resumo em CAB Abstracts on CD-ROM, 1984 - 86/

ENGLERT, W. D.; HOLZ, B. [Weather, phenology of the grape-vines, diseases, pests, beneficial arthropods and injuries in the viticulture 1985 and 1986.] Mitteilungen aus der Biologischen Bundesanstalt fur Land und Forstwirtschaft Berlin Dahlem, n.248, 1989. 43p. /Resumo em CAB Abstracts on CD-ROM, 1987-89/

EPENHUIJSEN, C. W. [Fruit tree gall mite (Aculus schlechtendali) a pest on apple trees not to be underestimated.] Fruitteelt, v.71, n.8, p.238-241, 1981. /Resumo em CAB Abstracts on CD-ROM, 1979-81/ 
ESAULOV, A. G.; ROSLAVTSEVA, S. A. [Protection of apple trees from codling moth and hawthorn mite in the south Krasnodar region.] Khimiya v Sel'skom Khozyaistve, v.21, n.8, p.36-38, 1983. /Resumo em CAB Abstracts on CD-ROM, 1984-86/

ESTRADA COTERO, S.; SANCHEZ GALVEZ, M. DEL C. Niveles de susceptibilidad de Tetranychus urticae K. (Acarida: Tetranychidae) a ocho acaricidas en el cultivo del clavel (Dianthus caryophyllus L.) en la región de Villa Guerrero, Mexico. Revista Chapingo, v.15, p.67-68, 1990. /Resumo em CAB Abstracts on CD-ROM, 1992/

EUROPEAN AND MEDITERRANEAN PLANT PROTECTION ORGANIZATION Guidelines on pest risk analysis. 1. Check list of information required for pest risk analysis (PRA). Bulletin OEPP/EPPO, v.23, p.191-198, 1993a.

\section{EUROPEAN AND MEDITERRANEAN PLANT PROTECTION ORGANIZATION} Guidelines on pest risk analysis. 2. Pest risk analysis to decide immediate action to be taken on interception of a pest in an EPPO country. Bulletin OEPP/EPPO, v.23, p.199-202, 1993b.

FAO. Global plant quarantine system. Rome, 1993. 1 disquete.

FAO. International standards for phytosanitary measures, Section 1. Import regulations: guidelines for pest risk analysis. Rome, 1995.

-FAO. Trade yearbook. Rome, 1994. 354p. (FAO, 48)

FARRIER, M. H.; ROCK, G. C.; YEARGAN, R. Mite species in North Carolina apple orchards with notes on their abundance and distribution. Environmental Entomology, v.9, n.4, p.425-429, 1980.

FATEMI, H. [Population fluctuation of Tetranychus (Tetranychus) turkestani (Ugarov \& Nikolski) in Esfahan.] Entomologie et Phytopathologie Appliquées, v.50, n.1/2, p.27-37, 1983a. /Resumo em CAB Abstracts on CD-ROM, 1984-86/ 
FATEMI, H. [The fauna of Coccinellidae in Esfahan Province.] Entomologie et Phytopathologie Appliquées, v.50, n.1-2, p.7-8, 1983b. /Resumo em CAB Abstracts on CD-ROM, 1984-86/

FAUVEL, G.; NAIBO, B.; GOFF, C. le; TESSIER, P.; LE GOFF, C. [Maize. Tetranychid mites.] Phytoma, n.388, p.23-27, 1987. /Resumo em CAB Abstracts on CD-ROM, 1990-91/

FERGUSSON KOLMES, L. A.; SCOTT, J. G.; DENNEHY, T. J. Dicofol resistance in Tetranychus urticae (Acari: Tetranychidae): cross resistance and pharmacokinetics. Journal of Economic Entomology, v.84, n.1, p.41-48, 1991.

FERRAGUT, F.; SANTONJA, M. C. Taxonomía y distribución de los ácaros del género Tetranychus Dufour 1832 (Acari: Tetranychidae), en España. Boletin de Sanidad Vegetal, Plagas, v.15, n.3, p.271-281, 1989. /Resumo em CAB Abstracts on CDROM, 1993-94/

FERRARI P., J. A. Efecto de la aplicación de cera y condiciones de almacenaje de frutos de chirimoyo (Anona cherimola Mill.) cv. bronceada sobre el control de la falsa arañita de la vid (Brevipalpus chilensis Baker) y en la evolución de la madurez en postcosecha. Quillota, 1991. 142p. Tesis (Ing. Agr.) - Facultad de Agronomia, Universidad Catolica de Valparaiso. /Resumo em AGRIS on CD-ROM, 1991-92/

FIGUEIREDO JR., E. R. A aranha vermelha da macieira. O Biológico, v.16, p.228$230,1950$.

FIRTH, D.J. Amarillo peanut: a perennial orchard groundcover. WANATCA Yearbook, v.17, p.69-73, 1993. /Resumo em AGRIS on CD-ROM, 1993-94/

FIRTH, D. J.; WILSON, G. P. M. Preliminary evaluation of species for use as permanent ground cover in orchards on the north coast of New South Wales. Tropical Grasslands, v.29, n.1, p.18-27, 1995. /Resumo em AGRIS on CD-ROM, 1995-96/ 
FISHER, M. J.; CRUZ, P. Some ecophysiological aspects of Arachis pintoi. In: KERRIDGE, P. C.; HARDY, B. (Ed.) Biology and agronomy of forage Arachis. Cali:CIAT, 1994. p. 53-70. (CIAT Publication, 240) /Resumo em AGRIS on CDROM, 1993-94/

FLAHERTY, D. L.; LYNN, C. D.; JENSEN, F. L.; LUVISI, D. A. Ecology and integrated control of spider mites in San Joaquin vineyards. California Agriculture, v.23, n.4, p.11, 1969

FLAHERTY, D.; LYNN, C.; JENSEN, F.; HOY, M. Correcting imbalances - spider mite populations in southern San Joaquin vineyards. California Agriculture, v.26, n. 4, p. $10-12,1972$.

FLECHTMANN, C. H. W. Ácaros encontrados sobre maçãs de procedência Argentina. Anais da Escola Superior de Agricultura "Luiz de Queiroz", v.24, p.83-85, 1967.

FLECHTMANN, C. H. W. Elementos de acarologia. São Paulo: Nobel, 1975. 344p.

FLECHTMANN, C. H. W. Ácaros de importância agrícola. São Paulo: Nobel, 1985. $189 \mathrm{p}$.

FLECHTMANN, C. H. W. Ácaros em produtos armazenados e na poeira domiciliar. Piracicaba: FEALQ, 1986. 97p.

FLEXNER, J. L.; WESTIGARD, P. H.; HILTON, R.; CROFT, B. A. Experimental evaluation of resistance management for twospotted spider mite (Acari: Tetranychidae) on southern Oregon pear: 1987-1993. Journal of Economic Entomology, v.88, n.6, p.1517-1524, 1995.

FORSYTHE JR., H. Y.; RINGS, R. W. Eriophyid mites new to Ohio. The Ohio Journal of Science, v.66, n.3, p.265, 1966.

FOSTER, G. N.; BARKER, J. A new biotype of red spider mite (Tetranychus urticae Koch) causing typical damage to tomatoes. Plant Pathology, v.27, p.47-48, 1978. 
FOSTER, J. A. Exclusion of plant pests by inspections, certifications and quarantines. In: PIMENTEL, D. (Ed.) CRC Handbook of pest management in agriculture. Boca Raton: CRC Press, 1991. v.1, p. 311-338.

FREIRE, C. J. S.; CAMELATTO, D.; CANTILLANO, R. F. F.; KOVALESKI, A.; FORTES, J. F. A cultura da maçã. Brasília: EMBRAPA, SPI, $1994.107 \mathrm{p}$. (Coleção Plantar, 19).

FUNAYAMA, K.; TAKAHASHI, Y. [Studies on control and management of apple (Malus pumila) rust mite Aculus schlechtendali (Nalepa), 1: Chemical control and evaluation as alternative food for predatory mites.] Bulletin of the Akita Fruit Tree Experiment Station, n.23, p.1-13, 1993. /Resumo em CAB Abstracts on CD-ROM, 1993-94/

FUNAYAMA, K.; TAKAHASHI, Y. [Resistance to fenpyroximate and pyridaben in two-spotted spider mite, Tetranychus urticae Koch. (Acari: Tetranychidae) in southern Akita Prefecture.] Bulletin of the Akita Fruit Tree Experiment Station, n.25, p. 19-30, 1995. /Resumo em CAB Abstracts on CD-ROM, Jan.-Oct. 1996/

GALETENKO, S. M. [Reducing the resistance of hawthorn mite to acaricides.] Khimiya v Sel'skom Khozyaistve, v.14, n.8, p.40-43, 1976. /Resumo em CAB Abstracts on CD-ROM, 1976- 78/

GALETENKO, S. M. [Resistance of tetranychid mites.] Zashchita Rastenii, n.12, p.21, 1978. /Resumo em CAB Abstracts on CD-ROM, 1979-81/

- GANAPATHI, N. Regulations and plant quarantine in international trade. In: CHAMP, B. R.; HIGHLEY, E.; JOHNSON, G. I. (Ed.) Postharvest handling of tropical fruits. Canberra: Australian Centre for International Agricultural Research, 1994. p. 50-52. /Resumo em AGRIS on CD-ROM, 1995-96/ 
GAZZONI, D. L. Sanidade vegetal como fator de competitividade no comércio internacional e de redução de impactos sociais e ambientais no país produtor. In: CONGRESSO BRASILEIRO DE ENTOMOLOGIA, 16., Salvador, 1997. Resumos. Cruz das Almas: EMBRAPA, CNPMF, 1997. p.5-6.

GEOFFRION, R. [Establishment of the first bases for agricultural warning stations in China, in the province of Shaanxi.] Phytoma, n.390, p.14-18, 1987. /Resumo em CAB Abstracts on CD-ROM, 1987- 89/

GEORGHIOU, G. P.; MELLON, R. B. Pesticide resistance in time and space. In: U. S. - JAPAN COOPERATIVE SCIENCE PROGRAM SEMINAR ON PEST RESISTANCE TO PESTICIDES: CHALLENGES AND PROSPECTS, Palm Springs, 1979. Pest resistance to pesticides: proceedings. New York: Plenum Press, 1983. p. 23-26.

GEORGIS, R. Notes and news. Insect pests and mites. PANS, v.23, n.3, p.327-329, 1977. /Resumo em CAB Abstracts on CD-ROM, 1976-78/

GILIOMEE, J. H.; PRINGLE, K. L. European red mite, Panonychus ulmi (Koch), discovered in South Africa. Phytophylactica, v.4, n.3, p.105-106, 1972. /Resumo em CAB Abstracts on CD-ROM, 1972/

GLASS, E. H. Recent developments in deciduous orchard pest management in the United States. Bulletin OEPP, v.5, n.2, p.101-111, 1975. /Resumo em CAB Abstracts on CD-ROM, 1976-78/

GOMEZ C., G. E.; VALLES, B.; CASTILLO, E.; JARILLO, J. Evaluación de métodos para el establecimiento de Arachis pintoi en una pastura nativa de Veracruz, Mexico. Pasturas Tropicales, v.16, n. 1, p.15-21, 1994.

GONZALEZ, R. H. Las arañitas rojas del manzano y del peral. Revista Fruticola, v.2, n.1, p.3-9, 1981. /Resumo em CAB Abstracts on CD-ROM, 1982-83/

GONZALEZ, R. H. La falsa arañita de la vid Brevipalpus chilensis Baker (Acarina, Tenuipalpidae). Revista Fruticola, v.4, n.2, p.61-65, 1983 . 
GONZALEZ, R. H. Manejo de plagas de la vid. Santiago: Universidad de Chile/Departamento de Sanidad Vegetal, 1983b. 115 p. (Publicaciones en Ciencias Agricolas, 10). /Resumo em CAB Abstracts on CD-ROM, 1984-86/

GONZALEZ, R. H. Desarrollo estacional de insectos y ácaros del manzano 1982-1984.

Revista Fruticola, v.5, n.1, p.3-9, 1984. /Resumo em CAB Abstracts on CDROM, 1984-86/

GONZALEZ, R. H. Plagas del kiwi en Chile. Revista Fruticola, v.7, n.1, p.13-27, 1986. /Resumo em CAB Abstracts on CD-ROM, 1987-89/

GOODWIN, S. Chemical control of bunch mite, Brevipalpus lewisi McGregor (Tenuipalpidae), on grapes in New South Wales. General and Applied Entomology, v.14, p.41-46, 1982. /Resumo em CAB Abstracts on CD-ROM, $1982-83 /$

GOODWIN, S. Insecticide resistance of mites: its impact on ornamental and other horticultural crops. Gosford: New South Wales Agriculture, 1992. 16p. /Resumo em AGRIS on CD-ROM, 1995-96/

GOTOH, T. [Annual life cycle of the hawthorn spider mite, Tetranychus viennensis Zacher (Acarina: Tetranychidae) on deciduous oak.] Japanese Journal of Applied Entomology and Zoology, v.28, n.4, p.254-59, 1984. /Resumo em CAB Abstracts on CD-ROM, 1984-86/

GOTOH, T. [Developmental zero of Tetranychus viennensis Zacher (Acarina: Tetranychidae) on deciduous oak.] Japanese Journal of Applied Entomology and Zoology, v.31, n.2, p.174-175, 1987. /Resumo em CAB Abstracts on CD-ROM, 1987-89/

GOUGH, N. Evaluation of miticides for the control of two-spotted mite Tetramychus urticae Koch on field roses in southern Queensland. Crop Protection, v.9, n.2, p.119-127, 1990. /Resumo em CAB Abstracts on CD-ROM, 1990-91/ 
GRAFTON CARDWELL, E. E.; GRANETT, J.; LEIGH, T. F. Spider mite species (Acari: Tetranychidae) response to propargite basis for an acaricide resistance management program. Journal of Economic Entomology, v.80, n.3, p.579-587, 1987.

GRAU, P. Dibeta: a promising material for Lygus bug and spider mite control in cotton. In: BELTWIDE COTTON PRODUCTION CONFERENCE, Dallas, 1987. Proceedings. Memphis: National Cotton Council of America, 1987. p.136-137. /Resumo em CAB Abstracts on CD-ROM, 1987-89/

GRAVENA, S. Rotação de acaricidas no MIP-citros: menos desequilibrio e resistência. Laranja, v. 15, n.2, p.375-395, 1994.

GROF, B. Forage attributes of the perennial groundnut Arachis pintoi in a tropical savanna environment in Colombia. In: INTERNATIONAL GRASSLAND CONGRESS, 15., Kyoto, 1985. Proceedings. Cali: CIAT, 1985. p.168-170. /Resumo em CAB Abstracts on CD-ROM, 1987-89/

GUIRGUIS, M. W.; MOHAMED, I. I.; EL RAHMAN, A. S. M. A. Cross-resistance to different acaricides in Rogor- and proclonol-selected strains of the mite Tetranychus arabicus Attiah. Agricultural Research Review, v.55, n.1, p.31-39, 1979. /Resumo em CAB Abstracts on CD-ROM, 1979-81/

GUTIERREZ, J. [Species of the genus Tetranychus Dufour (Acarina: Tetranychidae) of economic importance in Madagascar and the neighbouring islands. Competition between the complexes of Tetranychus neocaledonicus André and Tetranychus urticae Koch.] Acarologia, v.16, n.2, p.258-270, 1974.

GUTIERREZ, J.; KREITER, S.; BOLLAND, H. R.; COTTON, D. [Five species of Tenuipalpidae (Acari, Tetranychoidea) living on conifers in France and three of their predators, the caryotype of Oligomerismus oregonensis.] Acarologia, v.30, n.1, p.51-58, 1989. /Resumo em CAB Abstracts on CD-ROM, 1990-91/ 
HAJNAL, A.; KERENYINE-NEMESTOTHY, K. [Pesticide resistance of the spider mite (Tetranychus urticae Koch).] Novenyvedelem, v.21, n.12, p.537-543, 1985. /Resumo em CAB Abstracts on CD-ROM, 1987-89/

HALEY, M. J.; BAKER, L. (Ed.) Integrated pest management for walnuts. Berkeley: California University, Agricultural Sciences Publications, 1982. 96p. /Resumo em CAB Abstracts on CD-ROM, 1982-83/

HALEY, S.; CURRANS, K. G.; CROFT, B. A. A computer aid for decision-making in apple pest management. Acta Horticulturae, n.276, p.27-33, 1990.

HANNA, R.; WILSON, L. T.; ZALOM, F. G.; FLAHERTY, D. L.; LEAVITT, G. M. Spatial and temporal dynamics of spider mites (Acari: Tetranychidae) in 'Thompson Seedless' vineyards. Environmental Entomology, v. 25, n.2, p.370-382, 1996.

HASSAN, S. M.; SAAD, A. S.; MANSOUR, M. H. Evaluation of certain insecticides against aphids, jassids, whiteflies and red spider mites attacking cotton. Bulletin of the Entomological Society of Egypt. Economic Series, n.8, p.41-45, 1974. /Resumo em CAB Abstracts on CD-ROM, 1976-78/

HELLE, W.; VRIE, M. VAN DE Problems with spider mites. Outlook on Agriculture, v.8, n.3, p.119-125, 1974. /Resumo em CAB Abstracts on CD-ROM, 1972-75/

HERBERT, H. J. Note on feeding ranges of six species of predaceous mites (Acarina: Phytoseiidae) in the laboratory. The Canadian Entomologist, v.93, p.380-384, 1959.

HERBERT, H. J. Life history and habits of the brown mite, Bryobia arborea M. \& A. (Acarina: Tetranychidae) on apple in Nova Scotia. The Canadian Entomologist, v.94, n.9, p.934-941, 1962.

HERBERT, H. J. Notes on the biology of the apple rust mite Aculus schlechtendali (Prostigmata: Eriophyoidea), and its density on several cultivars of apple in Nova Scotia. The Canadian Entomologist, v.106, p.1035-38, Oct. 1974. 
HERBERT, H. J. Biology, life tables, and intrinsic rate of increase of the European red mite, Panonychus ulmi (Acarina: Tetranychidae). The Canadian Entomologist, v.113, p.65-71, 1981.

HERBERT, H. J.; SANFORD, K. H. The influence of spray programs on the fauna of apple orchards in Nova Scotia. The Canadian Entomologist, v.101, p.62-67, 1969.

HERNE, D. C.; BOND, E. J. Control by fumigants of winter eggs of European red mite, Panonychus ulmi (Acarina: Tetranychidae), on harvested apples. The Canadian Entomologist, v.113, n.2, p.121-126, 1981.

HERREN, H. R.; NEUENSCHWANDER, P. Biological control of cassava pests in Africa. Annual Review of Entomology, v.36, p.257-283, 1991.

HERRON, G. A.; EDGE, V. E.; ROPHAIL, J. Clofentezine and hexythiazox resistance in Tetranychus urticae Koch in Australia. Experimental and Applied Acarology, v.17, n.6, p.433-440, 1993.

HERRON, G. A.; EDGE, V. E.; ROPHAIL, J. The influence of fenbutatin-oxide use on organotin resistance in two-spotted mite Tetranychus urticae Koch (Acari: Tetranychidae). Experimental and Applied Acarology, v.18, n.11-12, p.753-755, 1994.

HERRON, G. A.; LEARMONTH, S. E.; ROPHAII, J.; BARCHIA, I. Clofentezine and fenbutatin oxide resistance in the two-spotted spider mite, Tetranychus urticae Koch (Acari: Tetranychidae) from deciduous fruit tree orchards in Western Australia. Experimental \& Applied Acarology, v.21, p.163-169, 1997.

HESSEIN, N. A.; PERRING, T. M. Homeopronematus anconai (Baker) (Acari: Tydeidae) predation on citrus flat mite, Brevipalpus lewisi McGregor (Acari: Tenuipalpidae). International Journal of Acarology, v. 14, n.2, p.89-90, 1988. 
HIRUKI, C. Plant diseases associated with mites as vectors of known viruses and unknown etiological agents. In: MARAMOROSCH, K. (Ed.) Plant diseases of viral, viroid, mycoplasm and uncertain etiology. Boulder: Westview Press, 1992. cap.8, p. 129-156.

HLUCHY, M.; POSPISIL, Z. [Damage potential of the phytophagous Eriophyidae and Tetranychidae mites (Acari; Tetrapodili, Prostigmata) in grapevine.] Ochrana Roslin, v.27, n.3/4, p.273-285, 1991. /Resumo em CAB Abstracts on CD-ROM, 1993-94/

HO, C. C.; CHEN, W. H. [Infestation of grape berry by spider mites.] Plant Protection Bulletin Taipei, v.36, n.3, p.251-255, 1994. /Resumo em CAB Abstracts on CDROM, 1996-97/

HO, CHYICHEN; LO, KANGCHEN; CHEN, WENHUA [Spider mites injurious to economic plants in Taiwan and the toxicity of twelve acaricides to two major species (Tetranychidae: Acari).] Journal of Agricultural Research of China, v.44, n.2, p.157-165, 1995. /Resumo em CAB Abstracts on CD-ROM, 1996-97/

HOHN, H.; HOPLI, H. U. [The apple rust mite - often overestimated, but hardly forecastable!] Schweizerische Zeitschrift fur Obst und Weinbau, v.126, n.9, p.259-266, 1990. /Resumo em CAB Abstracts on CD-ROM, 1990-91/

HOPPER, B. E. Ecological aspects of pest risk assessment. Bulletin OEPP/EPPO, v.21, p.587-594, 1991.

HOPPER, B. E. Pest risk analysis: defining the concept. In: APHIS-NAPPO INTERNATIONAL WORKSHOP ON THE IDENTIFICATION, ASSESSMENT, AND MANAGEMENT OF RISKS DUE TO EXOTIC AGRICULTURAL PESTS, Alexandria, 1991. International approaches to plant pest risk analysis: Proceedings. Ottawa: NAPPO, 1993. 3C-2, p. 19-30. /Resumo em CAB Abstracts on CD-ROM, 1993-94/ 
HOPPER, B. E.; CAMPBELL, W. P. Crop protection information needs: a NAPPO perspective. In: INTERNATIONAL CROP PROTECTION INFORMATION WORKSHOP, 1989. Proceedings. Wallingford: BPCC Wheatons, 1989. p.225233.

HOUGEN EITZMAN, D.; KARBAN, R. Mechanisms of interespecif competition that result in successful control of Pacific mites following inoculations of Willamette mites on grapevines. Oecologia, v.103, n.2, p.157-161, 1995.

HOY, M. A. Almonds (California). In: HELLE, W; SABELIS, M. W. (Ed.) Spider mites: their biology, natural enemies and control. Amsterdan: Elsevier, 1985. v.1B, cap.3.2.3, p.299-310.

HOY, M. A.; WESTIGARD, P. H.; HOYT, S. C. Release and evaluation of a laboratory-selected, pyrethroid-resistant strain of the predaceous mite Metaseiulus occidentalis (Acari: Phytoseiidae) in southern Oregon pear orchard and a Washington apple orchard. Journal of Economic Entomology, v.76, n.2, p.383388, 1983.

HOYT, S. C. Integrated chemical control of insects and biological control of mites on apple in Washington. Journal of Economic Entomology, v.62, n.1, p.74-86, 1969.

HOYT, S. C.; WESTIGARD, P. H.; CROFT, B. A. Cyhexatin resistance in Oregon populations of Tetranychus urticae Koch (Acarina: Tetranychidae). Journal of Economic Entomology, v.78, n.3, p.656-659, 1985.

HUANG, K. X.; HU, D. X. Current status of integrated pest management of apple in China. In: INTERNATIONAL CONGRESS OF PLANT PROTECTION, 11., Manila, 1987. 2p. /Resumo em AGRIS on CD-ROM, 1989-90/

HUDSON, W. B. Mite control with overtree sprinklers. In: ANNUAL MEETING WASHINGTON STATE HORTICULTURAL ASSOCIATION, 1970. Proceedings. Washington: Washington State Horticultural Association, 1971. v..66, n. 130, p.132-133. /Resumo em CAB Abstracts on CD-ROM, 1972-75/ 
HUGHES, A. M. The mites of stored food and houses. 2 ed. London: Ministry of Agriculture, Fisheries and Food, 1976. 400p. (Technical Bulletin, 9).

HUMERES, E.; KOVALESKI, A.; RIBEIRO, L. G. Resistência do ácaro vermelho europeu Panonychus ulmi (Koch, 1836) ao acaricida clofentezine em pomares de macieira nas regiões de São Joaquim (SC) e Vacaria (RS). In: CONGRESSO BRASILEIRO DE ENTOMOLOGIA, 15., Caxambu, 1995. Resumos. Lavras: Universidade Federal de Lavras, Departamento de Fitossanidade, 1995. p.17.

HURKOVA, J. Resistance to thiometon and tetradifon in green-house populations of the two-spotted spider mite Tetranychus urticae. Vestnik Ceskoslovenske Spolecnosti Zoologicke, v.41, n.3, p.176-184, 1977. /Resumo em CAB Abstracts on CDROM, 1976-78/

HURKOVA, J. Response of OP-resistant Tetranychus urticae (Acarina) to pyrethroids. Vestnik Ceskoslovenske Spolecnosti Zoologicke, v.48, n.2, p.102-106, 1984. /Resumo em CAB Abstracts on CD-ROM, 1984-86/

HURKOVA, J.; MATOLIN, S. Effects of two cyclopropane miticides on Tetramychus urticae (Acari, Tetranychidae). Acta Entomologica Bohemoslovaca, v.72, n.5, p.209-214, 1975. /Resumo em CAB Abstracts on CD-ROM, 1976-78/

HURKOVA, J.; WEYDA, F.; MUSKA, J. Pesticide resistance of spider mites in Czechoslovakia. In: INTERNATIONAL CONGRESS OF PLANT PROTECTION, 10., Brighton, 1983. Proceedings. Croydon: British Crop Protection Council, 1983. v.2, p. 636. /Resumo em CAB Abstracts on CD-ROM, 1984-86/

IACOB, N. [New mite pests on greenhouse crops and on grapevine.] Analele Institutului de Cercetari pentru Protectia Plantelor, v.14, p.115-120, 1978. /Resumo em CAB Abstracts on CD-ROM, 1979-81/ 
IACOB, N.; BRANCOVEANU, M.; MATEI, I.; POSOIU, V.; BUCIU, E. [Analysis of factors determining biological effectiveness in the control of mites in apple plantations.] Analele Institului de Cercetari pentru Protectia Plantelor, v.16, p.195-205, 1980. /Resumo em CAB Abstracts on CD-ROM, 1982-83/

INGLATERRA. Ministry of Agriculture, Fisheries and Food Bryobia mites. Northumberland: BPCC Graphics, 1985. 6p. (Leaflet 305)

IREN, Z.; OKUL, A. [Investigations on winter sprays and the possibilities of chemical control against Palaeolecanium bituberculatum Targ. on apple trees in central Anatolia.] Bitki Koruma Bulteni, v.14, n.1, p.29-42, 1974. /Resumo em CAB Abstracts on CD-ROM, 1972-75/

JAMES, D. G. Biological control of grapevine mites (Brevipalpus lewisi; Colomerus vitis; Calepitrimerus vitis). Yanco: New South Wales Agriculture, 1992. 95p. /Resumo em AGRIS on CD-ROM, 1995-96/

JANELA, N. M. B. Utilización de ácaros predadores en la lucha contra la araña roja. Fruticultura Profesional, n. 80, p.16-25, 1996.

JANSSEN, A.; YANINEK, J. S. Cassava green mites: A challenge for experts in biological control. Experimental \& Applied Acarology, v. 17, p. 1-4, 1993.

JEPPSON, L. R.; KEIFER, H. H.; BAKER, E. W. Mites injurious to economic plants. Berkeley: University of California Press, 1975. 614p.

JONES, R. M. Persistence of Arachis pintoi cv. Amarillo on three soil types at Samford, south-eastern Queensland. Tropical Grasslands, v.27, n.1, p.11-15, 1993. /Resumo em CAB Abstracts on CD-ROM, 1993-94/

- KAHAN, R. P. Plant protection and quarantine. Boca Raton: CRC Press, 1989. 226p. v.1: Biological concepts.

KANEDA, M. A supplementary list of Acarina intercepted in plant quarantine. Research Bulletin of Plant Protection Japan, v.30, p.125-126, 1993. 
KARBAN, R.; LOEB ENGLISH, G. M.; VERDEGAAL, P. Vaccinating grapevines against spider mites. California Agriculture, v.45, n. 1, p. 19-21, 1991.

KARG, W. [Investigations on the mite fauna of apple orchards with reference to the transition from standard spray programmes to integrated treatment measures.] Archiv fur Pflanzenschutz, v.7, n.4, p.243-279, 1971. /Resumo em CAB Abstracts on CD-ROM, 1972-75/

KARLIK, J. F.; GOODELL, P. B.; OSTEEN, G. W. Sampling and treatment thresholds for spider mite management in field-grown rose plants. HortScience, v.30, n.6, p.1268-1270, 1995.

KASSEMEYER, H. H. Integrated management of grapevine diseases and pests. In: BRIGHTON CROP PROTECTION CONFERENCE, PESTS AND DISEASES, Brighton, 1996. Proceedings. 1996. 3B-1, p.119-124

KEENA, M. A.; GRANETT, J. Cyhexatin and propargite resistance in populations of spider mites (Acari: Tetranychidae) from California almonds. Journal of Economic Entomology, v.80, n.3, p.560-564, 1987.

KEIFER, H. H. Eriophyid studies XVI. Bulletin of the California Department of Agriculture, v.35, n.1, p.39-48, 1946.

KEIFER, H. H. Eriophyid studies XIX. Bulletin of the California Department of Agriculture, v. 41, n.2, p.65-74, 1952.

KEIFER, H. H. Eriophyid studies B-1. Sacramento: California Bureau of Entomology, 1960. 20p. (Special Publications)

KEIFER, H. H. Eriophyid studies B-13. Sacramento: California Bureau of Entomology, 1965. 20p. (Special Publications)

KEIFER, H. H. Eriophyid studies C-1. Washington: USDA, Agricultural Research Service, 1969a. 20p. (Special Publication) 
KEIFER, H. H. Eriophyid studies C-2. Washington: USDA, Agricultural Research Service, 1969b. 20p. (Special Publication)

KHANOV, $O$. [The fauna and biology of plant mites in fruit orchards of the Kopet foothills in Turmenistan.] Izvestiya Akademii Nauk Turmenskoi SSR, Seriya Biologicheskikh Nauk, n.6, p.17-22, 1978. /Resumo em CAB Abstracts on CDROM, 1979-81/

KIM, S. S.; KIM, D. I.; LEE, S. C. [Joint toxic action of acaricide mixtures to the bifenthrin- and the cyhexatin-resistant strain of Tetranychus urticae.] Korean Journal of Entomology, v.23, n.1, p.41-48, 1993. /Resumo em CAB Abstracts on CD-ROM, 1993-94/

KINN, D. N.; DOUTT, R. L. Initial survey of arthropods found in North Coast vineyards of California. Environmental Entomology, v.1, n.4, p.508-513, 1972a.

KINN, D. N.; DOUTT, R. L. Natural control of spider mites on wine grape varieties in northern California. Environmental Entomology, v.1, n.4, p.513- 518, 1972 b.

KINN, D. N.; JOOS, J. L.; DOUTT, R. L.; SORENSEN, J. T.; FOSKETT, M. J. Effects of Tetranychus pacificus and irrigation pratices on yield and quality of grapes in north coast vineyards of California. Environmental Entomology, v.3, n.4, p.601-606, 1974.

KLUNKER, R. [The problem of resistance in spider-mites with special regard to dimethoate resistance.] Nachrichtenblatt fur den Pflanzenschutzdienst in der DDR, v.27, n.4, p.88-90, 1973. /Resumo em CAB Abstracts on CD-ROM, 1976$78 /$

KNOP, N. F.; HOY, M. A. Factors limiting the utility of Homeopronematus anconai (Acari: Tydeidae) in integrated pest management in San Joaquin Valley vineyards. Journal of Economic Entomology, v.76, n.5, p.1181-1186, 1983. 
KOGAN, M. Environmental impact of the introduction of quarantine pests. In: CONGRESSO BRASILEIRO DE ENTOMOLOGIA, 16.; Salvador, 1997. Resumos. Cruz das Almas: EMBRAPA, CNPMF, 1997. p.6.

KOLLNER, V. [Resistance to organic phosphorus compounds in spider mites from chrysanthemum cultures.] Nachrichtenblatt des deutschen Pflanzenschutzdienstes, v.25, n.1, p.7-11, 1973. /Resumo em CAB Abstracts on CD-ROM, 1972-75/

KOLMES, S. A.; DENNEHY, T. J.; SAM, Y. Contrasting behavior of twospotted spider mites (Acari: Tetranychidae) on discontinuous residues of a pyrethroid and a chlorinated hydrocarbon acaricide. Journal of Economic Entomology, v.87, n.3, p.559-565, 1994.

KOVALESKI, A.; VENDRAMIM, J. D. Biologia de Panonychus ulmi (Koch, 1836) (Acari: Tetranychidae) em macieira. Revista de Agricultura, Piracicaba, v.68, n. 1, p.27-41, 1993.

KOZLOWSKI, J. Researches on the occurrence and noxiousness of apple leaf mite Aculus schlechtendali (Nal.). Prace Naukowe Instytutu Ochrony Roslin, v.22, n.2, p.155-162, 1980. /Resumo em CAB Abstracts on CD-ROM, 1984-86/

KOZLOWSKI, J.; BOCZEK, J. Overwintering of the apple rust mite Aculus schlechtendali (Nal.) (Acarina: Eriophyoidea). Prace Naukowe Instytutu Ochrony Roslin, v.29, n. 1, p.51-62, 1987. /Resumo em CAB Abstracts on CD-ROM, 1990$91 /$

KOZLOWSKI, J.; KOZLOWSKA, M. [Intensity of Aculus schlectendali (Nal.) occurrence on selected apple-tree varieties.] In: PRUSZYNSKI, S.; LIPA, J. J. (Ed.) Materials of the 33rd research session of Institute for Plant Protection, 1994. p.227-230 /Resumo em AGRIS on CD-ROM, 1995-96/ 
KREMER, F. W. Change of species dominance among pests of intensively protected pome fruit crops in Italy. Pflanzenschutz Nachrichten Bayer, v.24, n.2, p.232-238, 1971. /Resumo em CAB Abstracts on CD-ROM, 1972-75/

KUIJPERS, L. A. M.; ZWAAN, J. The new acaricide Andalin: an option for IPM in orchards. Acta Phytopathologica et Entomologica Hungarica, v.27, n. 1-4, p.385392, 1992. /Resumo em CAB Abstracts on CD-ROM, 1993-94/

KUWAHARA, M.; SAWADA, M.; KUBOTA, A.; IWATA, N. [Susceptibility of the Kanzawa spider mite, Tetranychus kanzawai and the two-spotted spider mite, T. urticae, collected from vegetable and ornamental plants to organophosphorous insecticides and specific acaricides.] Japanese Journal of Applied Entomology and Zoology, v.27, n.4, p.289-294, 1983. /Resumo em CAB Abstracts on CD-ROM, $1984-86 /$

LAFFI, F. [Grapevine yellow spider-mite, Eotetranychus carpini Oud. f. vitis Dosse.] Informatore Fitopatologico, v.32, n.6, p.31-34, 1982. /Resumo em CAB Abstracts on CD-ROM, 1982-83/

LAFFI, F.; GIOVANNI, G. de [Populations of phytophagous mites of apples and their predators.] Italia Agricola, v.115, n.3, p.111-119, 1978. /Resumo em CAB Abstracts on CD-ROM, 1979-81/

LAKOCY, A. [Theoretical and practical aspects of resistance to pesticides in agricultural pests.] Prace Naukowe Instytutu Ochrony Roslin, v.14, n.2, p.5-85, 1972. /Resumo em CAB Abstracts on CD-ROM, 1976-78/

LASCANO, C. E.; THOMAS, D. Forage quality and animal selection of Arachis pintoi in association with tropical grasses in the eastern plains of Colombia. Grass and Forage Science, v. 43, n.4, p.433-439, 1988. /Resumo em CAB Abstracts on CD ROM, 1987-89/ 
LECLANT, F.; MILAIRE, H. G. [Integrated control in peach orchards in the south-east of France.] In: SYMPOSIUM ON INTEGRATED CONTROL IN ORCHARDS, 5., Bolzano, 1974. Proceedings. Wageningen: Organisation Internationale de Lutte Biologique contre les Animaux et les Plantes Nuisibles, 1975. p.181-198. /Resumo em CAB Abstracts on CD-ROM, 1976-78/

LEE, S. C.; YOO, J. K. [Studies on chemical resistance of mites. II. Orchard mite control and their resistance to Metasystox, Folidol and C-8514 in Korea.] Korean Journal of Plant Protection, v.10, n.2, p.109-116, 1971. /Resumo em CAB Abstracts on CD-ROM, 1972-75/

LEIGH, T. F. Cotton. In: HELlE, W.; SABELIS, M. W. (Ed.) Spider mites: their biology, natural enemies and control. Amsterdan: Elsevier, 1985. v.1, cap.3.2.8, p.349-358.

LEIGH, T.; GOODELL, P.;TOSCANO, N.; BURTON, V.; BENTLEY, W.; WILSON, L. T.; NATWICK, E. T.; ROBERTS, P.; DAVIS, R. M.; VARGAS, R.; FISCHER, B.; KEMPEN, H.; WRIGHT, S. Cotton. Pest management guidelines. UCPMG Publication, v.17, n.21-24, p.37-56, 1990. /Resumo em CAB Abstracts on CDROM, 1992/

LI, S. Y.; HARMSEN, R. Effects of low application rates of the pyrethroid $\mathrm{PP}_{321}$ on the apple orchard mite complex (Acari) in Ontario. The Canadian Entomologist, v.124, p.381-390, 1992.

LIDSTER, P. D.; SANFORD, K. H.; McRAE, K. B. Effects of modified atmosphere storage on overwintering populations of the apple rust mite and European red mite eggs. HortScience, v.16, n.3, p.328-329, 1981.

LIENK, S. E. Orchard mite control investigations - 1969. Proceedings of the New York State Horticultural Society, v.115, p.222-225, 1970. /Resumo em CAB Abstracts on CD-ROM, 1972-1975/ 
LIENK, S. E.; WATVE, C. M.; WEIRES, R. W. Phytophagous and predacious mites on apple in New York. Ithaca: Cornell University, New York State College of Agriculture and Life Sciences, 1980. 14p. (Search Agriculture, 6)

LIGUORI, M. [Contribution to the knowledge of vine mites in Tuscany.] Redia, v.63, p.407-415, 1980. /Resumo em CAB Abstracts on CD-ROM, 1982-83/

LITVINOV, P. I.; GLUSHKOVA, S. A.; BOL'SHAKOVA, V. N. [Pesticides for the protection of vineyards.] Zashchita Rastenii, Moscow, n.9, p.45-46, 1985. /Resumo em CAB Abstracts on CD-ROM, 1987-89/

LIU, C. Z.; HE, C. G. [Determination of the population intrinsic increase capacity of Tetranychus viennensis (Zacher).] Gansu Nongye Daxue Xuebao, v.26, n.2, p.184-188, 1991. /Resumo em CAB Abstracts on CD-ROM, 1992/

LIVSHITS, I. Z.; MITROFANOV, V. I.; STRUNKOVA, Z. I. [False spider mites: pests of decorative plants and tree plantations in parks. Part I.] Izvestiya Akademii Nauk Tadzhikskoi SSR, Biologicheskikh Nauk, n.1, p.47-54, 1980. /Resumo em CAB Abstracts on CD-ROM, 1979-81/

LOBZHANIDZE, T. D. [The development of resistance to organophosphorus insectacaricides in the hawthorn spider mite in the conditions of eastern Georgia and chemical measures for its control.] Soobshcheniya Akademii Nauk Gruzinskoi SSR, v.98, n.3, p.705-708, 1980. /Resumo em CAB Abstracts on CD-ROM, 1979-81/

LOEB ENGLISH, G. M.; FLAHERTY, D. L.; WILSON, L. T.; BARNETT, W. W.; LEAVITT, G. M.; SETTLE, W. H. Pest management affects spider mites in vineyards. California Agriculture, v.40, n.3/4, p.28-30, 1986.

LOEB ENGLISH, G. M.; KARBAN, R. Negative interactions between Willamette mites and Pacific mites: possible management strategies for grapes. Entomologia Experimentallis et Applicata, v.48, n.3, p.269-274, 1988. /Resumo em CAB Abstracts on CD ROM, 1987-1989/ 
LOLADSE, S. [Red spiders in orchards in the Georgian Soviet Socialist Republic (USSR) and possibilities of control.] Nachrichtenblatt fur den Pflanzenschutz in der DDR, v. 43, n.10, p.198-200, 1989. /Resumo em CAB Abstracts on CDROM, 1990-91/

LOPADZE, Z. P.; PARTSVANIYA, M. Sh. [Specific acaricides against the hawthorn spider mite.] Zashchita Rastenii, n.12, p.32, 1984. /Resumo em CAB Abstracts on CD-ROM, 1984-86/

LORENZATO, D.; SECCHI, V. A. Controle biológico de ácaros da macieira no Rio Grande do Sul: 1. Ocorrência e efeitos dos ácaros fitófagos e seus inimigos naturais em pomares submetidos ao controle biológico e com acaricidas. Revista Brasileira de Fruticultura, v.15, n.1, p.211-220, 1993.

LOZZIA, G. C.; NEPOMUCENO, R.; RANCATI, M. A. [Presence and distribution of Acari Phytoseiidae in some Lombardy vineyards.] Vignevini, v.11, n.11, p.31-35, 1984. /Resumo em CAB Abstracts on CD-ROM, 1984-1986/

M'BOOB, S. S. Pest risk assessment in Africa: prospects for the implementation of an internationally agreed procedure. In: APHIS-NAPPO INTERNATIONAL WORKSHOP ON THE IDENTIFICATION, ASSESSMENT, AND MANAGEMENT OF RISKS DUE TO EXOTIC AGRICULTURAL PESTS, Alexandria, 1991. International approaches to plant pest risk analysis: Proceedings. Ottawa: NAPPO, 1993. p.43-46. /Resumo em CAB Abstracts on CD-ROM, 1993-94/.

- MACDONALD, O. C.; MILLS, K. A. Plant quarantine treatments: are there alternatives to methyl bromide? In: BRIGHTON CROP PROTECTION CONFERENCE PESTS AND DISEASES, Brighton, 1994. Proceedings. Nottingham: Major Print, 1994. v.1, p. 183-189. 
MADSEN, H. F.; CARTY, B. E. Pest management: four years experience in a commercial apple orchard. Journal of the Entomological Society of British Columbia, v.74, p.3-6, 1977. /Resumo em CAB Abstracts on CD-ROM, 1976$78 /$

MANDERSLOOT, H. J. [Results with Apollo in Dutch apple growing.] Erwerbsobstbau, v.29, n.4, p.125-126, 1987. /Resumo em CAB Abstracts on CDROM, 1987-89/

MANSON, D. C. M. Mites of the families Tenuipalpidae and Tetranychidae intercepted entering New Zealand from overseas. New Zealand Journal of Science, v.10, p.664-674, 1967.

MANSON, D. C. M. A contribution to the study of the genus Rhizoglyphus Claparede, 1869 (Acarina: Acaridae). Acarologia, v.13, n.4, p.621-650, 1972a,

MANSON, D. C. M. New species and new records of eriophyid mites (Acarina: Eriophyidae) from New Zealand and the Pacific area. Acarologia, v.13, n.2, p.351$360,1972 b$.

- MARQUES, A. S. A.; PARENTE, P. M. G.; MARINHO, V. L. A.; BUSO, G. S. C. A quarentena e o intercâmbio de germoplasma vegetal no Brasil: a atuação do CENARGEN. Pesquisa Agropecuária Brasileira, v.30, n.2, p.143-154, 1995.

MASAKI, M. [A list of Acarina intercepted in Plant Quarantine.] Research Bulletin of Plant Protection Japan, v.27, p.87-92, 1991.

MASAKI, M.; HAYASE, T.; MIYAJMA, S. [Notes on eight species of spider mites and predacious thrips intercepted on squash imported from U.S.A., Mexico, Colombia and New Zealand.] Research Bulletin of Plant Protection Japan, v.27, p.107-114, 1991.

MATKOWSKI, A.; SCHADEGG, E. [Apple rust mite: a hitherto overlooked pest.] Havebrug: Gron Viden, 1988. 4p. (Publication, 19) /Resumo em CAB Abstracts on CD-ROM, 1987-89/ 
MATSUMOTO, K.; ELMER, H. S. Influence of pesticides on nontarget citrus pests in California's central valley. Proceedings of the International Society of Citriculture 1981, v.2, p.675-676, 1983. /Resumo em CAB Abstracts on CD-ROM, 1984-86/

McMURTRY, J. A. Citrus. In: HELLE, W.; SABELIS, M. W. (Ed.) Spider mites: their biology, natural enemies and control. Amsterdan: Elsevier, 1985. v.1, cap.3.2.7, p.339-347.

McNALLY, P. S.; FARNHAM, D. Effects of Willamette mite (Acari: Tetranychidae) on Chenin Blanc and Zinfandel grape varieties. Journal of Economic Entomology, v.78, n.4, p.947-50, 1985.

MENON, M. G. R.; GHAI, S.; KATIYAR, K. N. Two new records of false spider mites from India (Acarina: Tenuipalpidae). Indian Journal of Entomology, v.33, n.4, p.469-470, 1971. /Resumo em CAB Abstracts on CD-ROM, 1972-75/

MEYER, M. K. P.S. The Tenuipalpidae (Acari) of Africa with keys to the world fauna. Pretoria: Government Printer, 1979. 135p. (Department of Agricultural Technical Services, Entomology Memoir, 50)

MEYER, M. K. P. S. Some new South African Eriophyidae (Acari: Eriophyoidea), with description of a new genus. International Journal of Acarology, v.16, n.2, p.89101, 1990a.

MEYER, M. K. P. S. A review of species of Aceria Keifer (Acari: Eriophyidae) associated with Acacia spp. International Journal of Acarology, v. 16, n.3, p. 149$173,1990 \mathrm{~b}$.

MICHAILIDES, T. J. Three common pests of pistachio in California. California Agriculture, v.44, n.3, p.6-8, 1990.

MIJUSKOVIC, M. [Harmful mites on citrus fruits.] Poljoprivreda i Sumarstvo, v.27, n.3, p.3-22, 1981. /Resumo em CAB Abstracts on CD-ROM, 1982-83/ 
MILLER, D. J.; CONNELL, W. A. Host-plant spectrum of strawberry spider mite. Entomological News, v.85, n.5-6, p.175-179, 1974. /Resumo em CAB Abstracts on CD-ROM, 1976-78/

MILLER, R. W.; CROFT, B. A.; NELSON, R. D. Effects of early season immigration on cyhexatin and formetanate resistance of Tetranychus urticae (Acari: Tetranychidae) on strawberry in central California. Journal of Economic Entomology, v.78, n.6, p.1379-1388, 1985.

MITROFANOV, V. I.; SHARONOV, A. A. [Contribution to the ecology of the hazelnut mite (Tetranychoidea, Bryobiidae) in the Crimea.] Trudy Gosudarstvennogo Nikitskogo Botanicheskogo Sada, v.99, p.110-119, 1986. /Resumo em CAB Abstracts on CD-ROM, 1987-89/

MIZUKOSHI, T. [Acaricide resistance of the twospotted spider mite (Tetranychus urticae Koch) on apple crops in Hokkaido. II. Susceptibilities to five acaricides, phenisobromolate, binapacryl and propargite predominantly.] Bulletin of Hokkaido Prefectural Agricultural Experiment Stations, n.59, p.57-65, 1989. /Resumo em CAB Abstracts on CD-ROM, 1987-89/

MOHYUDDIN, A. I. Interim report on the research programme to develop integrated pest management of fruit and vegetable pests in the Malakand division and transfer the technology to farmers. 1992. 50p. (Swat: Malakand Fruit \& Vegetable Development Project, 1992) /Resumo em CAB Abstracts on CD-ROM, 1993-94/

MONETTI, L. N.; FERNANDEZ, N. A. Seasonal population dynamics of the European red mite (Panonychus ulmi) and its predator Neoseiulus californicus in a sprayed apple orchard in Argentina (Acari: Tetranychidae, Phytoseiidae). Acarologia, v.36, n.4, p.325-331, 1995. 
MONTANO C., P. R. Control de Brevipalpus chilensis Baker. Falsa arañita de la vid en Vitis vinifera $\mathrm{L}$. cultivar Cabernet Sauvignon mediante aplicaciones de aceite mineral. Santiago, 1995. 34p. Tesis (Ing. Agr.) - Escuela de Agronomia, Universidad de Chile. /Resumo em AGRIS on CD-Rom, 1995-96/

MONTEIRO, L. B. Ocorrência de Polyphagotarsonemus latus (Banks) (Acari: Tarsonemidae) em videiras em Bento Gonçalves, RS, Brasil. Anais da Sociedade Entomológica do Brasil, v.23, n.2, p.349-350, 1994.

MORAES, G. J. A catalog of the family Phytoseiidae: references to taxonomy, synonymy, distribution and habitat. Brasília: EMBRAPA-DDT, 1986. 353p.

MORALES, F. J.; CASTAÑO, M.; VELASCO, A. C.; ARROYAVE, J.; ZETTLER, F. W. Natural infection of tropical forage legume species of Arachis and Stylosanthes by potyviruses related to peanut mottle virus. Plant Disease, v.75, n.11, p.10901093, 1991.

MUIR, R. C.; CRANHAM, J. E. Resistance to pesticides in damson-hop aphid and red spider mite on English hops. In: BRITISH CROP PROTECTION CONFERENCE PESTS AND DISEASES, Brighton, 1979. Proceedings. Surrey: British Crop Protection Council, 1980. p.161-167. /Resumo em CAB Abstracts on CD-ROM, $1979-81 /$

MYBURGH, A. C.; BOSMAN, I. P. Red spider control experiments on apples, 1970. Deciduous Fruit Grower, v.20, p.266-268, 1970. /Resumo em CAB Abstracts on CD-ROM, 1972-1975/

NAVVAB GOJRATI, H. A.; ZARE, N. Evaluation of acaricides for mite control on sunflower in southern Iran with notes on the mites of safflower. Indian Journal of Entomology, v.40, n.2, p.136-138, 1978a. /Resumo em CAB Abstracts on CDROM, 1979-81/ 
NAVVAB GOJRATI, H. A.; ZARE, N. Resistance of different varieties of sunflower and safflower to Tetranychus turkestani Ugarov and Nikolski in southern Iran. Indian Journal of Entomology, v.40, n.3, p.299-302, 1978b. /Resumo em CAB Abstracts on CD-ROM, 1979-81/

NIELSEN, G. L. Biology of the Mc Daniel mite, Tetranychus mcdanieli McGregor in Utah. Journal of Economic Entomology, v. 51, n.5, p.588-592, 1958.

NIKOLOV, N.; KHINKIN, S.; STRAKA, F. [Spider mites as pests of maize.] Rasteniev"dni Nauki, v.20, n.5, p.31-38, 1983. /Resumo em CAB Abstracts on CD-ROM, 1984-86/

NOMURA, K. Acaricide resistance in orchard mites. Japan Pesticide Information, n.6, p.31-34, 1971. /Resumo em CAB Abstracts on CD-ROM, 1972-75/

OATMAN, E. R. An ecological study of arthropod populations on apple in northeastern Wisconsin: Population dynamics of mite species on the foliage. Annals of the Entomological Society of America, v.66, n. 1, p.122-131, 1973.

OATMAN, E. R.; McMURTRY, J. A.; GILSTRAP, F. E.; VOTH, V. Effect of releases on Amblyseius californicus, Phytoseiulus persimilis and Typhlodromus occidentalis on the two-spotted spider mite on strawberry in southern California. Journal of Economic Entomology, v.70, p.45-47, 1977.

OBERHOFER, H.; GRAFFIN, P. Plant protection in the orchards of south Tyrol. Pastpresent- future. In: SYMPOSIUM ON INTEGRATED CROP PROTECTION, Valence, France, 1980. Proceedings. Rotterdam: A. A. Balkema, 1982. p. 235262. /Resumo em CAB Abstracts on CD-ROM, 1982-83/

OLIVEIRA, C. A. L. Ação dos ácaros Polyphagotarsonemus latus (Banks, 1904) e Tetranychus (T.) urticae Koch, 1836 na depreciação quantitativa e qualitativa da produção algodoeira. Piracicaba, 1972. 150p. Tese (Doutorado) - Escola Superior de Agricultura "Luiz de Queiroz", Universidade de São Paulo. 
OLIVEIRA, C. A. L.; CALCAGNOLO, G. Ação do "ácaro branco" Polyphagotarsonemus latus (Banks, 1904) na depreciação quantitativa e qualitativa da produção algodoeira. O Biológico, v.40, p.139-149, 1974.

OLSEN, A. R. Food-contaminating mites from imported foods entering the United States through southern California. International Journal of Acarology, v.9, n.4, p.189-193, 1983.

OMOTO, C. Magnitude do problema de resistência de pragas a pesticidas. In: CONGRESSO BRASILEIRO DE ENTOMOLOGIA, 16., Salvador, 1997. Resumos. Cruz das Almas: EMBRAPA, CNPMF, 1997. p.7.

OMOTO, C.; NAKANO, O. Avaliação de danos e controle do ácaro branco Polyphagotarsonemus latus (Banks, 1904) (Acari: Tarsonemidae) na cultura de feijão Phaseolus vulgaris L. cv. carioca 80. In: SEMINÁRIO SOBRE PRAGAS E DOENÇAS DO FEIJOEIRO, 3., Piracicaba, 1988. Anais. Piracicaba: FEALQ, 1988. p.11.

ONG, S. H.; BALLANTYNE, G. H. Acaricidal resistance and genetic affinities of some two-spotted spider mite population in New Zealand. New Zealand Journal of Zoology, v.1, n.4, p.523-530, 1974. /Resumo em CAB Abstracts on CD-ROM, 1976-78/

ORMAN, T.; BAKANLIGI, K. [Studies on the interaction between damage to apple by the buckthorn red spider mite, Tetranychus viennensis Zacher (Acarina: Tetranychidae) and its predator Stethorus punctillum Weise (Coleoptera: Coccinellidae).] Arastirma Yayinhari Serisi Yayin, n.62, 92p., 1989. /Resumo em CAB Abstracts on CD-ROM, 1992/

OTTO, D. [On the resistance of the common spider mite Tetranychus urticae Koch and the green peach aphid Myzus persicae Sulz to metamidophos.] Nachrichtenblatt fur den Pflanzenschutz in der DDR, v.42, n.9, p.184-186, 1988. /Resumo em CAB Abstracts on CD-ROM, 1987-89/ 
OVERMEER, W. P. J.; ZON, A. Q. VAN; HELLE, W.; VAN ZON, A. Q. The stability of acaricide resistance in spider mite (Tetranychus urticae) populations from rose houses. Entomologia Experimentalis et Applicata, v.18, n.1, p.68-74, 1975. /Resumo em CAB Abstracts on CD-ROM, 1972-75/

PALEVSKY, E.; OPPENHEIM, D.; REUVENY, H.; GERSON, U. Impact of European red mite on Golden Delicious and Oregon Spur apples in Israel. Experimental and Applied Acarology, v.20, p.343-354, 1996.

PALM, G. [The leaf and bud mite Aculus schlechtendali (Nal.) and its importance for our plant protection in apple (Malus) cultivation.] Mitteilungen des Obstbauversuchsringes des Alten Landes, v.40, n.4, p.140-150, 1985. /Resumo em AGRIS on CD-ROM, 1986/

PARADIS, R. O.; RIVARD, I.; VRAIN, T.; MAILLLOUX, M. The pests of fruit crops of south-western Quebec in 1978. Annals of the Entomological Society of Quebec, v.24, n.2, p.81-84, 1979. /Resumo em CAB Abstracts on CD-ROM, 1979-81/

PARK, H. M.; CHOI, S. Y.; YOO, J. K.; NA, S. Y.; LEE, K. H. [Chemical resistance of apple orchard mites (Panonychus ulmi Koch and Tetranychus urticae Koch) and their control with several acaricides.] Research Reports of the Rural Development Administration, Plant Environmental, Mycology and Farm Products Utilization, Korea Republic, v.28, n.2, p.65-71, 1986. /Resumo em CAB Abstracts on CD-ROM, 1987-89/

PARRELA, M. P.; Mc CAFFREY, J. P.; HORSBURGH, R. L. Population trends of selected phytophagous arthropods and predators under different pesticide programs in Virginia apple orchards. Journal of Economic Entomology, v.74, n.4, p.492$498,1981$. 
PEÑA, J. E. Analysis of insect outbreaks of quarantine pests in Florida. In: CONGRESSO BRASILEIRO DE ENTOMOLOGIA, 16., Salvador, 1997. Resumos. Cruz das Almas: EMBRAPA, CNPMF, 1997. p.5.

PFEIFFER, D. G.; PFEIFFER, S. W. Relative susceptibility to slide-dip application of cyhexatin in three populations of Panomychus ulmi (Koch) in Virginia apple orchards. Journal of Agricultural Entomology, v.3, n.4, p.326-328, 1986. /Resumo em CAB Abstracts on CD-ROM, 1987-89/

PITRE, D.; BOSTANIAN, N. J. Preventive treatment against injurious mites on apple (Panonychus ulmi and Aculus schlechtendali). Resume des Recherches, Station de Recherches, Saint Jean, Quebec, v.9, p.25-26, 1980. /Resumo em CAB Abstracts on CD-ROM, 1979-81/

POLLAK, R. T.; DRINKALL, M. J. Activity of bifenthrin against the fruit tree red spider mite and apple rust mite in top fruit in the UK. In: BRITISH CROP PROTECTION CONFERENCE - PESTS AND DISEASES, Brighton, 1990. Proceedings. Thornton Heath: British Crop Protection Council, 1990. .321-326. /Resumo em CAB Abstracts on CD-ROM, 1990-91/

PRICE, D. W. Passage of Verticillium albo-atrum propagules through the alimentary canal of the bulb mite. Phytopathology, v.66, p.46-50, 1976.

PRITCHARD, A. E.; BAKER, E. W. A guide to the spider mites of deciduous fruit trees. Hilgardia, v.21, n.9, p.253-287, 1952.

PRITCHARD, A. E.; KEIFER, H. H. Two new species of Bryobia with a revised key to the genus (Acarina: Tetranychidae). Annals of the Entomological Society of America, v.51, n.5, p.503-506, 1958.

PROKOPY, R. J.; COLI, W. M.; HISLOP, R. G.; HAUSCHILD, K. I. Integrated management of insect and mite pests in commercial apple orchards in Massachusetts. Journal of Economic Entomology, v.73, n.4, p.529-535, 1980. 
PROKOPY, R. J.; CROFT, B. A. Apple insect pest management. In: METCALF, R. L.; LUCKMANN, W. H. (Ed.) Introduction to insect pest management. 3. ed. New York: Willey Interscience, 1994 . cap. 13, p. 543-585.

RABBINGE, R. Aspects of damage assessment. In: HELLE, W.; SABELIS, M. W. (Ed.) Spider mites: their biology, natural enemies and control. Amsterdan: Elsevier, 1985. cap. 3.1, p.261-272.

RAJKOVIC, D. [Investigations into the dynamics of phytophagous Acarina population from the Tetranychidae family on soybean.] Subotica - Yugoslavia, 1988, p.77-79, 1988. /Resumo em AGRIS on CD-ROM, 1991-92/

RAMBIER, A. M. [The present situation of Tetranychus mite control in viticulture.] Progrès Agricole et Viticole, v.96, n.11, p.236-241, 1979. /Resumo em CAB Abstracts on CD-ROM, 1979-81/

RAMBIER, A. M. [A mite in Champagne vineyards is a newcomer to France: Tetranychus mcdanieli McGregor 1931 in pacificous group.] Progrès Agricole et Viticole, v.99, n.11, p.261-266, 1982b.

RAMDEV, Y. P.; LINDQUIST, R. K.; HALL, F. R. Evaluation of resistance to Pentac and bifenthrin in nine spider mite populations from Ohio greenhouses. Ohio Florists' Association Bulletin, n.704, p.6-8, 1988. /Resumo em CAB Abstracts on CDROM, 1987-89/

RATHMAN, R. J.; BEERS, E. H.; FLEXNER, J. L.; RIEDL, H.; HOYT, S. C.; WESTIGARD, P. H.; KNIGHT, A. L. Baseline bioassays with hexythiazox and clofentezine of three mite species (Acari: Tetranychidae) ocurring on Washington and Oregon tree fruits. Journal of Economic Entomology, v.83, n.5, p.1711-1714, 1990.

READSHAW, J. L. The ecology of Tetranychid mites in Australian orchards. Journal of Applied Ecology, v.12, n.2, p.473-495, 1975. /Resumo em CAB Abstracts on CD-ROM, 1972-75/ 
REIS FILHO, W; PETRI, J. L. Efeito de tratamentos para a quebra de dormência em macieira no controle do ácaro vermelho europeu. Agropecuaria Catarinense, v.5, n.2, p.35-37, 1992. /Resumo em CAB Abstracts on CD-ROM, Jan.-Oct. 1995/

RIBEIRO, L. G.; VILLACORTA, A.; FOERSTER, L. A. Life cycle of Panonychus ulmi (Koch, 1836, Acari: Tetranychidae) in apple trees, cultivar Gala and Golden Delicious. Acta Horticulturae, n.232, p.228, 1988. /Resumo em CAB Abstracts on CD-ROM, 1990-1991/

RICE, R. E.; JONES, R. A.; HOFFMAN, M. L. Seasonal fluctuations in phytophagous and predaceous mite populations on stonefruits in California. Environmental Entomology, v.5, n.3, p.557-564, 1976.

RICE, R. E.; WEINBERGER, G. B. Citrus flat mite on pistachios in California. California Agriculture, v.35, p.7-8, p.25-26, 1981. /Resumo em CAB Abstracts on CD-ROM, 1982-1983/

RICHTER, P.; SCHULZE, H. U. [Investigations on the resistance spectrum of a greenhouse population of the two-spotted spider mite, Tetranychus urticae Koch from Gross Gaglow (district of Cottbus).] Archiv fur Phytopathologie und Pflanzenschutz, v.26, n.6, p.551-556, 1990. /Resumo em CAB Abstracts on CDROM, 1992/

RISHI, N. D.; RATHER, A. Q. Euseius vignus a new species (Phytoseiidae: Acari) from Jammu and Kashmir. Entomon, v.8, n.3, p.303-305, 1983. /Resumo em CAB Abstracts on CD-ROM, 1984-86/

RIZK, G. A.; SHETA, I. B.; ALI, M. A. Chemical control of mites infesting grape-vine in Middle Egypt. Bulletin de la Société Entomologique d'Egypte, n.11, p.105111, 1978a. /Resumo em CAB Abstracts on CD-ROM, 1982-83/ 
RIZK, G. A.; SOLIMAN, Z. R.; ALI, M. A. Survey on mites associated with citrus and grape-vine in Minia region, Egypt. Bulletin de la Société Entomologique d'Egypte, n.62, p.105-110, 1978b. /Resumo em CAB Abstracts on CD-ROM, 1982-83/

RIZZIERI, D. A.; DENNEHY, T. J.; GLOVER, T. J. Genetic analysis of dicofol resistance in two populations of twospotted spider mite (Acari: Tetranychidae) from New York apple orchards. Journal of Economic Entomology, v.81, n.5, p.12711276, 1988.

ROCK, G. C. Summer evaluation of hexythiazox and clofentezine against three spider mite species in North Carolina apple orchards. Journal of Agricultural Entomology, v.4, n.1, p.55-60, 1987. /Resumo em CAB Abstracts on CD-ROM, 1987-89/

RODRIGUEZ, J. A.; ARIAS, A.; SANTIAGO, R.; NIETO, J. Observaciones sobre la biología de Brevipalpus lewisi (McGregor) en viñedos de la Comarca de Guarena (Badajoz), 1984-1986. Boletin de Sanidad Vegetal, Plagas, v.13, n.3, p.249-259, 1987. /Resumo em CAB Abstracts on CD-ROM, 1987-89/

ROIVAINEN, H. Some gall mites (Eriophyidae) from Spain. Arquivos del Instituto de Aclimatación, v.1, p.9-41, 1953.

ROTA, P.; CIAMPOLINI, M. Intensi e diffusi attacchi di alcuni Eriofidi su pomacee in Italia. Bolletino di Zoologia agraria e Bachicoltura., v.8, n.2, p.33-39, 1966-67.

RUSS, K.; FISCHER COLBRIE, P.; RUPF, O.; COLBRIE, P. FISCHER [Observations on the incidence of Vasates (Aculus) schlechtendali and Panonychus ulmi in an apple orchard] Zeitschrift fur angewandte Zoologie, v.61, n.4, p.439-457, 1974. /Resumo em CAB Abstracts on CD-ROM, 1972-75/. 
SAITO, T.; TABATA, K.; KOHNO, S. Mechanisms of acaricide resistance with emphasis on dicofol. In: U. S. - JAPAN COOPERATIVE SCIENCE PROGRAM SEMINAR ON PEST RESISTANCE TO PESTICIDES: CHALLENGES AND PROSPECTS, Palm Springs, 1979. Pest resistance to pesticides: proceedings. New York: Plenum Press, 1983. p.429-444.

SANCES, F. V.; TOSCANO, N. C.; LAPRE, L. F.; OATMAN, E. R.; JOHNSON, M. W. Spider mites can reduce strawberry yields. California Agriculture, v.36, p.15$16,1982$.

SANFORD, K. H.; STEWART, D. K. R.; POAPST, P. A. Fumigation on apples under plastic tarpaulins with ethylene dibromide to control diapausing European red mite (Acarina: Tetranychidae) eggs. The Canadian Entomologist, v.108, n.2, p.217-223, 1976.

SCHLIESSKE, J. [On the biology and harmfulness of the gall mite Aculus schlechtendali (Nalepa) (Acari: Eriophyoidea) on Malus spp. in nurseries and orchards.] Mitteilungen aus der biologischen Bundesanstalt fur Land und Forstwirtschaft, n. 223, p.149, 1984. /Resumo em CAB Abstracts on CD-ROM, 1984-86/

SCHRUFT, G. A. Grape. In: HELLE, W.; SABELIS, M. W. (Ed.) Spider mites: their biology, natural enemies and control. Amsterdan: Elsevier, 1985. v.1B, cap. 3.2.9, p.359-366.

SCHWARTZ, A. Pesticide effect on populations of Tetranychus urticae Koch (Acari: Tetranychidae) and a predaceous mite on table grapes in the Hex River Valley. South African Journal of Enology and Viticulture, v.11, n.1, p.33-37, 1990. /Resumo em CAB Abstracts on CD-ROM, 1990-91/

SELIM, A. A. Some notes on the activity of certain insect predators and parasites of the Hammam Al-Alil area. Mesopotamia Journal of Agriculture, v.12, n.1, p.65-73, 1977. /Resumo em CAB Abstracts on CD-ROM, 1976-78/ 
SEPASGOSARIAN, H. [The red false spider mite of apple Cenopalpus pulcher (Can. \& Fanz.) (Acari - Tenuipalpidae).] Bulletin of the Agricultural College, Karadj., n.115, 1970. 37p. /Resumo em CAB Abstracts on CD-ROM, 1972-75/

SEPASGOZARIAN, H.; SCHRUFT, G. [The spider mite Tetranychus viennensis Zacher (Acari: Tetranychidae), a new fruit-tree pest in Iran.] Journal of Entomological Society of Iran, v.2, n.2, p.59-60, 1975. /Resumo em CAB Abstracts on CD-ROM, 1976-78/

SGRILLO, R. Os novos paradigmas do comércio internacional e o risco de introdução de pragas quarentenárias. In: CONGRESSO BRASILEIRO DE ENTOMOLOGIA, 16., Salvador, 1997. Resumos. Cruz das Almas: EMBRAPA, CNPMF, 1997. p.6.

SHEN, H.; ZHONG, X. Study on the insecticide-resistance of Tetranychus viennensis Zacher. Journal of Gansu Agricultural University, v.29, n.3, p.250-254, 1994. /Resumo em AGRIS on CD-ROM, 1995-96/

SIMONS, N. H. R. La "arañuela parda" Bryobia rubrioculus (Scheuten) en la República Argentina. Revista de Investigaciones Agropecuarias . Serie 5. Patología vegetal, v.1, n.4, p.39-46, 1964.

SINGH, S. Pest risk analysis and its implications for pest and disease exclusion in international germplasm exchange. In: SUGARCANE GERMPLASM CONSERVATION AND EXCHANGE INTERNATIONAL WORKSHOP, Brisbane, 1996. Report. Canberra: Australian Centre for International Agricultural Research, 1996. p.100-107. /Resumo em CAB Abstracts on CD-ROM, 1996$1997 /$

SKIBA, N. S.; PARII, I. F. [Pests and diseases of cherry.] Zashchita Rastenii Moskva, n.8, p.48-51, 1989. /Resumo em CAB Abstracts on CD-ROM, 1990-91/ SKORUPSKA, A. [The occurrence of mites (Tetranychidae) in apple orchards in Greater Poland.] Prace Naukowe Instytutu Ochrony Roslin, v.18, n.2, p.183-196, 1976. /Resumo em CAB Abstracts on CD-ROM, 1979-81/ 
SKORUPSKA, A. [The occurrence of spider mites (Tetranychidae) in the plum orchards of Wielkopolska.] Prace Naukowe Instytutu Ochrony Roslin, v.21, n.2, p.149161, 1979. /Resumo em CAB Abstracts on CD-ROM, 1979-81/

SKORUPSKA, A.; BOCZEK, J. Effect of the host plants change on the reproduction of hawthorn spider mite (Tetranychus viennensis Zacher). Prace Naukowe Instytutu Ochrony Roslin, v.27, n.1, p.5-22, 1985. /Resumo em CAB Abstracts on CDROM, 1987-89/

SLYKHUIS, J. T. Mites. In: HARRIS, K. F.; MARAMOROSCH, K (Ed.) Vectors of plant pathogens. London: Academic Press, 1980. p. 326-355.

SMOL'YANNIKOV, V. V. [Pests of apple.] Zashchita Rastenii, v.15, n.8, p.36-37, 1970. /Resumo em CAB Abstracts on CD-ROM, 1972-75/

SOENEN, A.; VAN WETSWINKEL, G.; PATTERNOTTE, E. Mites: important pests of fruit trees in Europe. Span, v.20, n.2, p.55-57, 1977.

SOLHOY, T.; DYBWAD, E.; HESJEDAL, K.; HOSSAIN, M.; HOVLAND, B. Observations on Aculus schlechtendali (Nal.) (Acari: Eriophyidae) in apple orchards in western Norway. In: DUSBABEK, F.; BUKVA, V. (Ed.) Modern acarology. Prague: Academia; The Hague: SPB Academic Publ., 1991. v.1, p. 533-538.

SOLIMAN, Z. R.; ZAHER, M. A.; EL SAFI, G. S. Control of Cenopalpus spp. on deciduous fruit trees in Egypt (Acarina: Tenuipalpidae). Bulletin de la Société Entomologique d'Egypte, Economic Series, n.8, p.57-62, 1974. /Resumo em CAB Abstracts on CD-ROM, 1976-78/

SOLOMON, M. E. Tyroglyphid mites in stored products: methods for the study of population density. Annals of Applied Biology, v.32, n.1, p.71-75, 1945. 
SONG, CHEOL; KIM, GIL HAH; AHN, SOO JEONG; PARK, NO JOONG; CHO, KWANG YUN. [Acaricide susceptibilities of field-collected populations of twospotted spider-mite, Tetranychus urticae (Acari: Tetranychidae) from apple orchards.] Korean Journal of Applied Entomology, v.34, n.4, p.328-333, 1995. /Resumo em CAB Abstracts on CD-ROM, Jan.-Oct. 1996/

SORENSEN, J. T.; KINN, D. N.; DOUTT, R. L. Biological observations on Bdella longicornis: a predatory mite in California vineyards (Acari: Bdellidae). Etmography, v.2, p.297-305, 1983. /Resumo em CAB Abstracts on CD ROM, 1984-86/

SOUZA FILHO, M. F. DE; SUPLICY FILHO, N.; SATO, M. E.; TAKEMATSU, A. P. Suscetibilidade do ácaro-rajado proveniente de videiras de Pilar do Sul, SP, a diversos acaricidas. Pesquisa Agropecuária Brasileira, v.29, n. 8, p.1187-1192, 1994.

STAFFORD, E. M.; KIDO, M. Newer insecticides for the control of grape insect and spider mite pests. California Agriculture, v.23, n.4, p.6-8, 1969.

STAMENKOVIC, T.; STAMENKOVIC, S.; PERIC, P. [Acquisition of resistance to propargite in Panonychus ulmi Koch. (Tetranychidae).] Zastita Bilja, v.36, n.1, p.81-86, 1985. /Resumo em CAB Abstracts on CD-ROM, 1984-86/

STERK, G. Control of the fruit tree red spider mite (Panonychus ulmi) and the apple rust mite (Aculus schlechtendali) in apple orchards. In: BRIGHTON CROP PROTECTION CONFERENCE - PESTS AND DISEASES, Brighton, 1994. Proceedings. Nottingham: Major Print, 1994. v.2, 5B-1, p.559-568.

STONE, L. E. W.; LANE, A.; HAMMON, R. P.; GOULD, H. J.; POTTER, R. F. Aldicarb-treatment of year-round chrysanthemums for control of red spider mite, Tetranychus urticae (Koch), in 1976. Plant Pathology, v.26, n.3, p.109-111, 1977. /Resumo em CAB Abstracts on CD-ROM, 1976-78/ 
STRAPAZZON, A.; MONTA, L. D. [Role and distribution of Amblyseius andersoni (Chant) and Zetzellia mali (Ewing) in apple orchards infested by Aculus schlechtendali (Nalepa).] Redia, v.71, p.39-54, 1988. /Resumo em CAB Abstracts on CD-ROM, 1990-91/

SUAREZ V., S; WOOD, M.; NORTCLIFF, S. Crecimiento y fijación de nitrógeno por Arachis pintoi establecido con Brachiaria decumbens. Cenicafé, v.43, n.1, p.14-21, 1992.

SUMMERS, F. M.; STOCKING, C. R. Some immediate effects on almond leaves of feeding by Bryobia rubrioculus (Scheuten). Acarologia, v.14, n.2, p.170-178, 1972.

SUN, S. Q.; YANG, S. H.; GUO, Q. H.; CHEN, H. [Experiment on the effect of four acaricides.] Journal of Fruit Science, v.9, n.1, p.23-25, 1992. /Resumo em CAB Abstracts on CD-ROM, Jan.-Oct. 1995/

SUTHERST, R. W. Predicting the survival of immigrant insect pests in new environments. Crop Protection, v.10, p.331-333, 1991.

SUTHERST, R. W.; MAYWALD, G. F; BOTTOMLEY, W. From CLIMEX to PESKY, a generic expert system for pest risk assessment. Bulletin OEPP/EPPO, v.21, p.595-608, 1991.

TAGEL'SIR, EL'AMIN A. [Resistance of a greenhouse population of the red spider mite.] Zashchita Rastenii, n.10, p.30-31, 1990. /Resumo em CAB Abstracts on CD-ROM, 1992/

TAKEMATSU, A. P.; SUPLICY FILHO, N.; SOUZA FILHO, M. F.; SATO, M. E. Sensibilidade de Tetranychus urticae (Koch, 1836), proveniente de roseira (Rosa sp.) de Holambra-SP, a alguns acaricidas. Revista de Agricultura, Piracicaba, v.69, n.2, p.127-137, 1994. 
TANIGOSHI, L. K.; BABCOCK, J. M. Cyhexatin resistance and enhancement with calcium chloride in Washington State populations of spider mites (Acari: Tetranychidae) on pome fruit. Journal of Entomological Science, v.25, n.2, p.325335, 1990. /Resumo em CAB Abstracts on CD-ROM, 1990-91/

TANIGOSHI, L. K.; BROWNE, R. W. Coupling the cytological aspects of spider mite feeding to economic injury levels on apple. Protection Ecology, v.3, n.1, p.29-40, 1981. /Resumo em CAB Abstracts on CD-ROM, 1982-83/

TANIGOSHI, L. K.; HOYT, S. C.; BROWNE, R. W.; LOGAN, J. A. Influence of temperature on population increase of Tetranychus mcdanieli (Acarina: Tetranychidae). Annals of the Entomological Society of America, v.68, n.6, p.972-978, 1975.

THOMPSON, S. C. A. Efecto de la aplicación de cera y aceite en frutos de chirimoyo (Annona cherimola Mill.) cv. Concha lisa, sobre el control de la falsa arañita de la vid (Brevipalpus chilensis Baker.), y evaluación del comportamiento de la fruta en post cosecha. Quillota, 1990. 98p. Tesis (Ing. Agr.) - Facultad de Agronomia, Universidad Catolica de Valparaiso. /Resumo em AGRIS on CD-ROM, 1991-92/

TRAPMAN, M.; BLOMMERS, L. The introduction of IPM in apple orchards. Mededelingen van de Faculteit Landbouwwetenschappen, Rijksuniversiteit Gent., v.50, n.2a, p.425-30, 1985. /Resumo em CAB Abstracts on CD-ROM, 1987-89/

TSAGKARAKOU, A.; NAVAJAS, M.; LAGNEL, J.; GUTIERREZ, J.; PASTEUR, N. Genetic variability in Tetranychus urticae (Acari: Tetranychidae) from Greece: Insecticide Resistance and Isozymes. Journal of Economic Entomology, v.89, n.6, p.1354-1358, 1996.

TURCANU, P. [Study of the effectiveness of some compounds in the control of mites on grapevine.] Cercetari Agronomice in Moldova, v.25, n.3, p.101-104, 1992. /Resumo em CAB Abstracts on CD-ROM, Jan.-Oct., 1995/ 
TUZUN, S.; GURSES, A. [Tests of a treatment against Tetranychus viennensis Zacher, a pest of peach in the Marmara region.] Tarim Bakanligi Zirai Mucadele ve Zirai Karantina Genel Mudurlugu Arastirma Subesi: Plant Protection Research Annual: Zirai Mucadele Arastirma Yilligi, v.39, p.167, 1972. /Resumo em CAB Abstracts on CD-ROM, 1972-75/

UNIVERSITY OF CALIFORNIA Integrated pest management for apples and pears. Berkeley: University of California, 1991. p.110-116. (Division of Agriculture and Natural Resources Publication, 3340).

UNWIN, B. Chemical resistance in populations of Tetranychus urticae (Koch) (Acarina: Tetranychidae) from apple orchards in New South Wales, Australia. Journal of the Australian Entomological Society, v.12, n.1, p.59-67, 1973. /Resumo em CAB Abstracts on CD-ROM, 1972-75/

USPENSKII, F. M. [The Turkestan cotton spider mite.] Zashchita Rastenii, n.6, p.4748, 1978. /Resumo em CAB Abstracts on CD-ROM, 1979-81/

VAN DE VRIE, M. Apple. In: HELLE, W.; SABELIS, M. W. (Ed.) Spider mites: their biology, natural enemies and control. Amsterdan: Elsevier, 1985a. v.1B, cap.3.2.4, p.311-325.

VAN DE VRIE, M. Greenhouse ornamentals. In: HELLE, W.; SABELIS, M. W. (Ed.) Spider mites: their biology, natural enemies and control. Amsterdan: Elsevier, 1985b. v.1, cap. 3.2 .1$, p.273-283.

VARGAS, C.; MERAYO, A.; AGUILAR, H. Identificación de ácaros en coberturas vivas y malezas en Costa Rica. Manejo Integrado de Plagas, n.40, p.40-43, 1996.

VEIGA, A. F. S. L. Aspectos bioecológicos e alternativas de controle do ácaro verde da mandioca Mononychellus tanajoa (Bondar, 1938) (Acarina: Tetranychidae) no Estado de Pernambuco. Piracicaba, 1985. 137p. Tese (Doutorado) - Escola Superior de Agricultura "Luiz de Queiroz", Universidade de São Paulo. 
VERA M., J. P. Eficacia de la aplicación de cera en pruebas de laboratorio y en frutos de maracuya (Passiflora edulis) sobre el control de la falsa arañita roja de la vid Brevipalpus chilensis Baker. Quillota, 1991. 94p. Tesis (Ing. Agr.) - Facultad de Agronomia, Universidad Catolica de Valparaiso. /Resumo em AGRIS on CD-Rom, $1991-92 /$

VERMA, B. R.; KAPUR, M. Eriophyid mites (Acari: Eriophyoidea) of arid zone fruit crops and quarantine. Indian Journal of Entomology, v.52, n.2, p.249-252, 1990.

VILARREAL, M; CHAVEZ, O. Adaptación y producción de gramíneas y leguminosas forrajeras en San Carlos, Costa Rica. Pasturas Tropicales, v. 13, n.2, p.31-38, 1991. /Resumo em CAB Abstracts on CD-ROM, 1993-94/

VILLACARLOS, L. T.; VASQUEZ, E. A. Arthropod pests of cassava and their control. Crops State of the Art and Abstract Bibliography Series, n.15, p.31-36, 1988. /Resumo em CAB Abstracts on CD-ROM, 1990-91/

VILLARONGA, P.; COSIALLS, J. R.; BONET, J. Mite fauna associated to peach orchards in LLeida (Spain). Bulletin- OLB-SROP, v.16, n.4, p.14-21, 1993. /Resumo em CAB Abstracts on CD-ROM, 1993-94/

VILLARONGA, P.; GARCIA MARI, F. Relación entre las especies de ácaros tetraniquidos y fitoseidos en los avellanos de Tarragona. Boletin de Sanidad Vegetal, Plagas, v.18, n.2, p.441-454, 1992. /Resumo em CAB Abstracts on CDROM, 1993-94/

VILLARONGA, P.; MARQUES, J.; CASANOVAS, S.; FERRAGUT, F. [The phytophagous and predatory mites in vineyards of the "Alt Emporda" (GeronaSpain).] Progrès Agricole et Viticole, v.108, n.23, p.519-523, 1991. /Resumo em CAB Abstracts on CD-ROM, 1992/

VINUELA, E. Las arañas rojas, grave amenaza para los frutales (Panonychus ulmi, Tetranychus urticae e Bryobia rubrioculus). Tria, n.407, p.63-64, 1984. /Resumo em AGRIS on CD-ROM, 1981-85/ 
VOGT, H.; DICKLER, E.; GRAUHAN, H. Effects of a single application of acaricides in apple orchards on the population dynamics of Panonychus ulmi (Acari, Tetranychidae) and Aculus schlechtendali (Acari, Eriophyoidea) with special regard to beneficials. Journal of Applied Entomology, v.110, n.1, p.35-54, 1990. /Resumo em CAB Abstracts on CD-ROM, 1990-91/

VRABL, S. [The influence of the vine as food-plant on some biological characteristics of fruit-tree red spider mite.] Zastita Bilja, v.25, n.130, p.241-250, 1974. /Resumo em CAB Abstracts on CD-ROM, 1976-78/

WEHNER, F. [The effect of time and duration of infestation by Tetramychus turkestani Ug. et Nic. on plant growth, yield and quality of cotton in central Asia.] Beitrage zur Tropischen Landwirtschaft und Veterinarmedizin, v.27, n.2, p.203-209, 1989. /Resumo em CAB Abstracts on CD-ROM, 1990-91/

WELTER, S. C.; FARNHAM, D. S.; McNALLY, P. S.; FREEMAN, R. Effect of Willamette mite and Pacific spider mite (Acari: Tetranychidae) on grape photosynthesis and stomatal conductance. Environmental Entomology, v.18, n.6, p.953-957, 1989b.

WELTER, S. C.; FREEMAN, R; FARNHAM, D. S. Recovery of 'Zinfandel' grapevines from feeding damage by Willamette spider mite (Acari: Tetranychidae): implications for economic injury level studies in perennial crops. Environmental Entomology, v.20, n.1, p.104-109, 1991.

WELTER, S. C.; McNALLY, P. S.; FARNHAM, D. S. Effect of Willamette mite (Acari: Tetranychidae) on grape productivity and quality: a reappraisal. Environmental Entomology, v.18, n.3, p.408-411, 1989a.

WERTHEIM, S. J. Towards an integrated fruit production in the Netherlands. Acta Horticulturae, n.285, p.25-32, 1990. /Resumo em CAB Abstracts on CD-ROM, $1990-91 /$ 
WESTIGARD, P. H.; BERRY, D. W. Life history and control of the yellow spider mite on pear in southern Oregon. Journal of Economic Entomology, v.63, n.5, p.1433$1437,1970$.

WESTIGARD, P. H.; GUT, L. J.; LISS, W. J. Selective control program for the pear pest complex in southern Oregon. Journal of Economic Entomology, v.79, n.1, p.250-257, 1986.

WILDEMAN, G. [Glasshouse fruit. Biological control of mites can be satisfactory.] Groeten en Fruit, v.30, n.42, p.1959, 1975. /Resumo em CAB Abstracts on CDROM, 1972-75/

WISNIEWSKI, J.; HIRSCHMANN, W. Triplogynium ligniphilum sp. nov., a mite species (Triplogyniidae) introduced into Poland on exotic timber. Acarologia, v.34, n.1, p.13-16, 1993.

WORLD METEOROLOGICAL ORGANIZATION. Climatological normals. Genebra, 1996. 768p. (Publication, 847)

WU, T. K.; LIN, S. R.; LO, K. C. [Selectivity of acaricides to two-spotted spider mite, Tetranychus urticae Koch and the predatory mite, Amblyseius californicus (McGregor).] Journal of Agricultural Research of China, v.34, n.4, p.469-476, 1985. /Resumo em CAB Abstracts on CD-ROM, 1984-86/

WYSOKI, M. Other outdoor crops. In: HELLE, W.; SABELIS, M. W. (Ed.) Spider mites: their biology, natural enemies and control. Amsterdan: Elsevier, 1985. v.1, cap.3.2.12, p.375-384.

YANINEK, J. S.; MORAES, G. J. A synopsis of classical biological control of mites in agriculture. In: DUSBABEK, F.; BUKVA, V. (Ed..) Modern acarology. Prague: Academia; The Hague: SPB Academic Publ., 1991. v.1, p.133-149. 
YIGIT, A.; UYGUN, N. Investigations on the population dynamics of hawthorn mite, Tetranychus viennensis Zacher (Acarina: Tetranychidae) and its predators in apple orchards. Cukurova Universitesi Ziraat Fakultesi Yilligi, v.13, n.2, p.64-69, 1982. /Resumo em CAB Abstracts on CD-ROM, 1984-86/

YOUSEF, A. T. A. Mites associated with vine trees in the U. A. R. Zeitschrift fur angewandte Entomologie, v.67, n.1, p.1-6, 1970. /Resumo em CAB Abstracts on CD-ROM, 1972-75/

ZAHER, M. A.; RASMY, A. H.; ABOU-AWAD, B. A. Ecological studies on mites infesting deciduous fruit trees in lower Egypt. Zeitschrift fur angewandte Entomologie, v.69, n.1, p.59-64, 1971. /Resumo em CAB Abstracts on CDROM, 1972-75/

ZAHER, M. A.; SOLIMAN, Z. R.; EL SAFI, G. S. Survey and population studies on mites associated with deciduous fruit trees in Giza, Egypt. Bulletin de la Société Entomologique d'Egypte, v.57, p.425-433, 1973. /Resumo em CAB Abstracts on CD-ROM, 1972-75/

ZAHER, M. A.; SOLIMAN, Z. R.; EL SAFI, G. S. Biological studies on Cenopalpus pulcher (Canestrini and Fanzago) (Acarina: Tenuipalpidae). Bulletin de la Société Entomologique d'Egypte, v.58, p.367-373, 1974. /Resumo em CAB Abstracts on CD-ROM, 1976-78/

ZHANG, N. X.; DENG, X.; CHEN, J. F.; CAO, Z. L.; REN, H. L.; JA, X. F. [Biological control of apple spider mites by Metaseiulus occidentalis Nesbitt (Acari: Phytoseiidae).] Chinese Journal of Biological Control, v.3, n.3, p.97-101, 1987. /Resumo em CAB Abstracts on CD-ROM, 1987-89/

ZHANG, N. X.; DENG, X.; CHEN, J. F.; CHEN, Y. G.; CAO, Z. L.; REN, H. L.; JIA, X. F. [Preliminary study on geographic adaptability of Typhlodromus occidentalis Nesbitt.] Acta Phytophylactica Sinica, v.15, n.2, p.105-109, 1988. /Resumo em CAB Abstracts on CD-ROM, 1990-91/ 
ZIL'BERMINTS, I. V.; SMIRNOVA, A. A.; MATOV, G. N.; PARKHOMENKO, A. A. (Ed.) [Resistance of the hawthorn spider mite to organophosphorus acaricides in apple orchards of Azerbaijan.] Ustoichivost' Vreditelei $\mathbf{k}$ Khimicheskim Sredstvam Zashchity Rastenii, p.27-32, 1979. /Resumo em CAB Abstracts on CD-ROM, 1982-83/

ZWICK, R. W.; FIELDS, G. J.; MELLENTHIN, W. M. Effects of mite population density on "Newton" and "Golden Delicious" apple tree performance. Journal of the American Society of Horticultural Science, v. 101, n.2, p.123-125, 1976. 